\title{
Szálkai Kinga
}

A vízmegosztás kérdése a nemzetközi kapcsolatok elméletében:

Vízügyi konfliktusok és együttmüködések Közép-Ázsiában a XXI. század elején 
Nemzetközi Tanulmányok Intézet

\author{
Témavezető: \\ Dr. Dobrovits Mihály, PhD \\ programigazgató, BHKKA \\ Dr. Marton Péter, PhD \\ egyetemi adjunktus
}

2016

(C) Szálkai Kinga

MINDEN JOG FENNTARTVA 


\section{CORVINUS

Budapesti Corvinus Egyetem

Nemzetközi Kapcsolatok Multidiszciplináris Doktori Iskola

Nemzetközi és biztonsági tanulmányok alprogram

A vízmegosztás kérdése a nemzetközi kapcsolatok elméletében: Vízügyi konfliktusok és együttműködések Közép-Ázsiában a XXI. század elején

doktori értekezés

Szálkai Kinga 



\section{TARTALOMJEGYZÉK}

Tartalomjegyzék

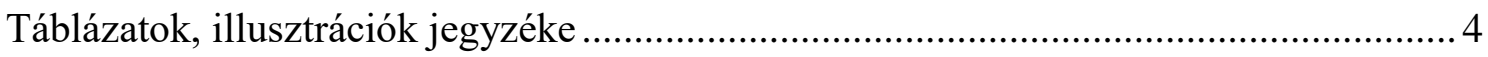

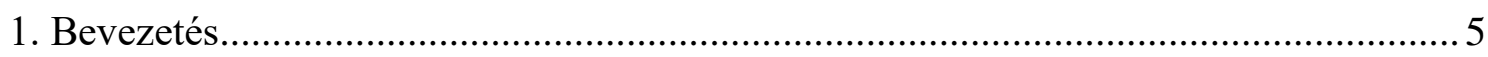

1.1. Vízügyi kérdések a XXI. században................................................................ 5

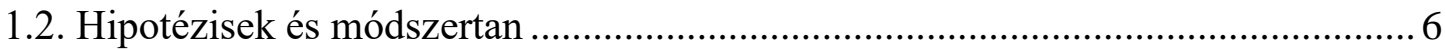

1.3. Az értekezés szerkezete és a felhasznált szakirodalom áttekintése ..................... 10

2. Vízügyi kérdések a nemzetközi kapcsolatok elméletében ....................................... 17

2.1. Vízbiztonság: A XXI. század egyik legfontosabb kihívása ............................... 17

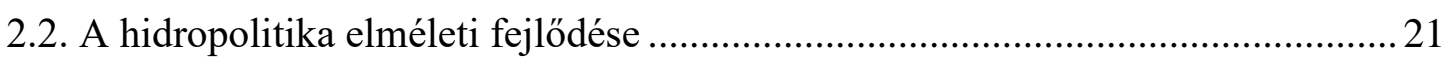

2.3. A hagyományos racionalista elméletek hidropolitikai megközelítései ................ 22

2.3.1. A neorealista neo-malthusiánus megközelítés ............................................. 22

2.3.2. A neoliberális bőségszaru-megközelítés .................................................... 26

2.3.3. A racionalista elméletek kritikái.................................................................. 31

2.4. A konstruktivizmus alapvetései és hidropolitikai megközelítései ...................... 34

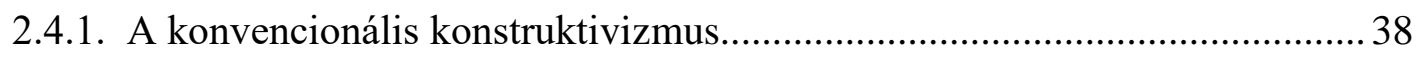

2.4.2. Hidropolitikai kérdések konstruktivista elméleti keretben ..........................4 41

2.4.3. A koppenhágai iskola elmélete: szektorelmélet és biztonságiasítás.............. 42

2.4.4. A hidropolitikai biztonsági komplexumok elmélete................................... 51

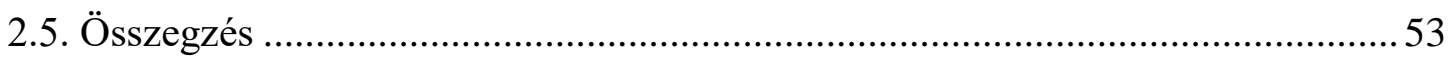

3. Esettanulmány: a közép-ázsiai hidropolitikai biztonsági komplexum.......................55

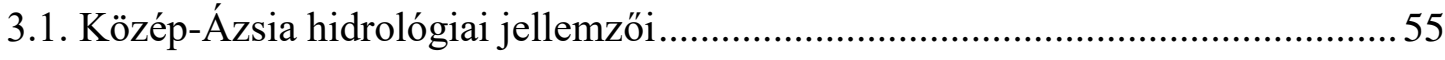

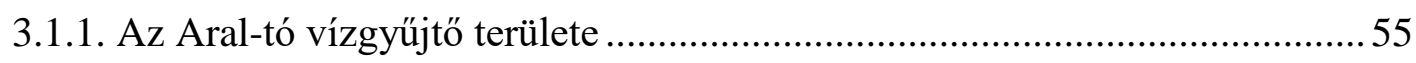

3.1.2. Közép-Ázsia és a vízbiztonsági kihívások................................................ 57

3.1.3. Vízigazgatási rendszerek közép-ázsiában a xx. Században.......................... 58

3.2. Közép-Ázsia államainak vízbiztonsági helyzete .............................................. 62

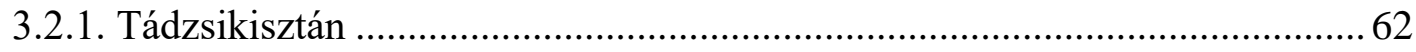

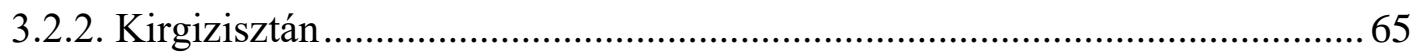

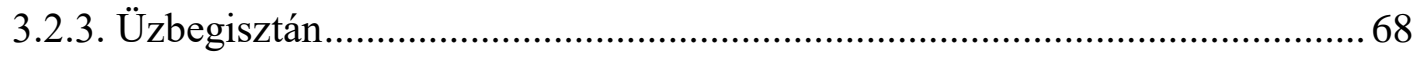

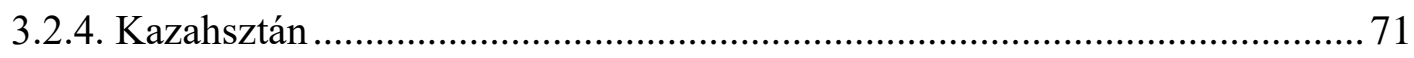

3.3. A Rogun és a Kambar-ata I. vízerőmü-rendszerek az államközi kapcsolatokban 72

3.3.1. Konfliktusok a Rogun vízerőmü-rendszer körül ...................................... 72

3.3.2. Együttmüködési törekvések a Kambar-ata I. kapcsán és azon túl................. 78 


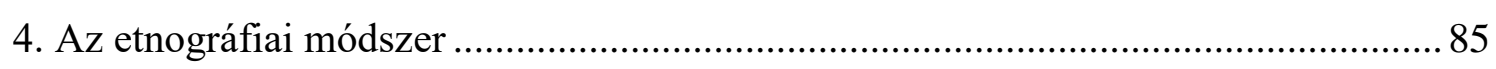

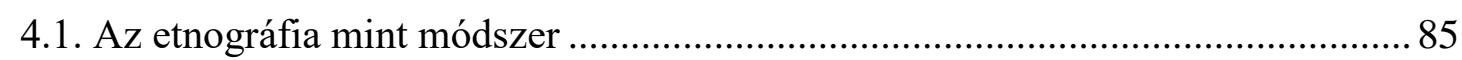

4.2. A vízigazgatás mint strukturáló erő az öntözéses gazdálkodáson alapuló

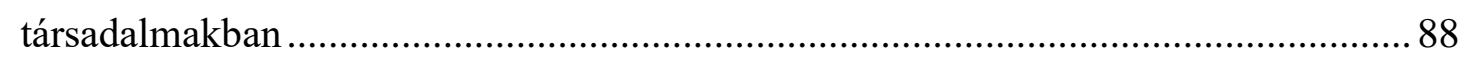

4.3. Nagyméretű gátrendszerek a Szovjetunióban: Modernizáció és szovjetesítés..... 92 4.4. Nagyméretü gátrendszerek az újonnan függetlenedett köztársaságokban: Az

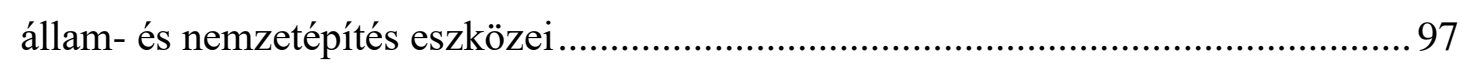

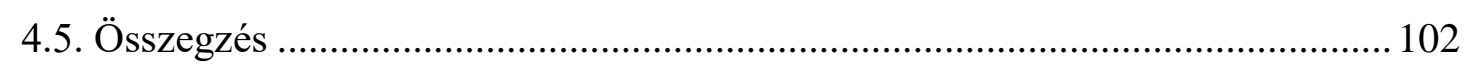

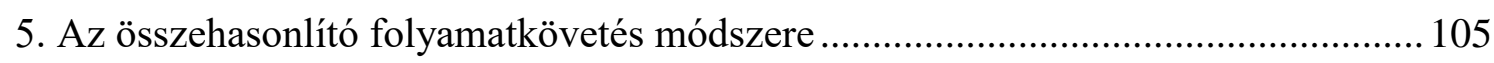

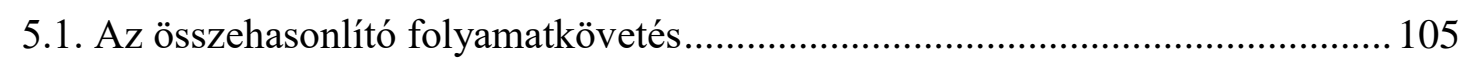

5.2. A Szovjetunió időszaka - Vízbiztonság a gazdasági szektorban ....................... 107

5.3. Az 1990-es évek - Vízmegosztás, a politikai biztonság egyik fő háttérfeltétele110

5.4. 2000 után - Vízbiztonság a gazdasági és politikai szektorban........................... 113

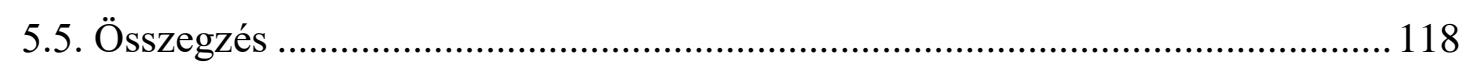

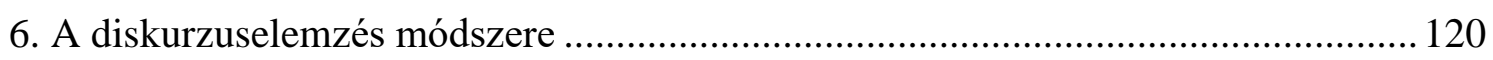

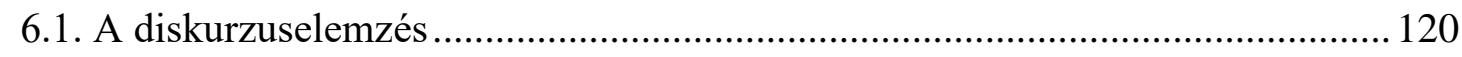

6.2. Konfliktus vagy együttmüködés? Vízügyi diskurzusok Közép-Ázsiában .......... 124

6.2.1. Vízügyi diskurzusok I.: A szovjet időszak ................................................ 124

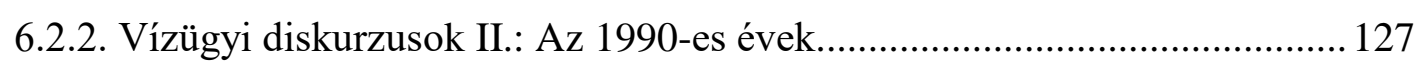

6.2.3. Vízügyi diskurzusok III.: Az ezredforduló után ........................................ 129

6.3. Az együttműködés és konfliktus narratívái az állami hírügynökségek idegen

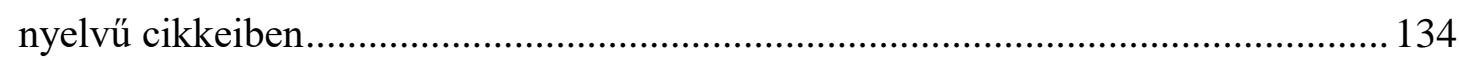

6.3.1. A Tádzsikisztán-Üzbegisztán állampár és a Rogun gátrendszer narratívái. 135

6.3.2. A Kirgizisztán-Kazahsztán állampár és a Kambar-ata I. gátrendszer...... 140

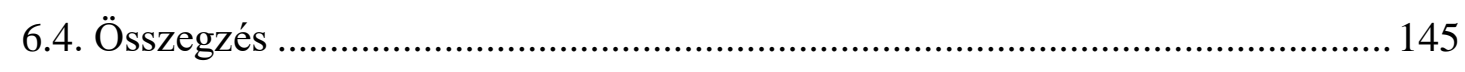

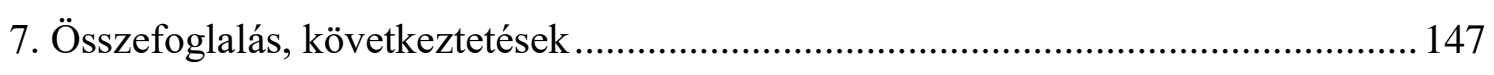

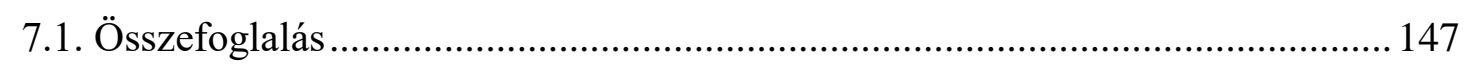

7.2. Az értekezés eredményei és a kutatás további irányai .................................... 149

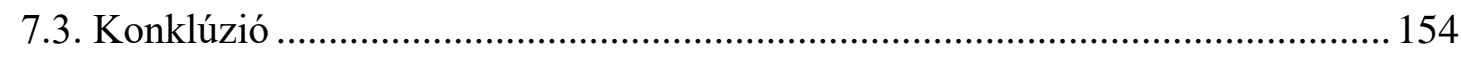

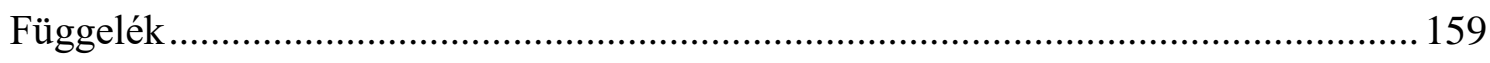

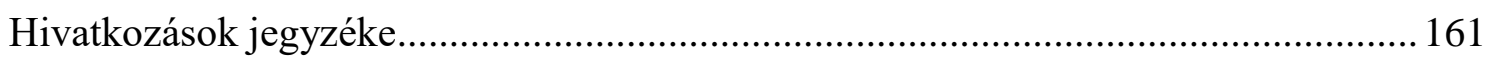

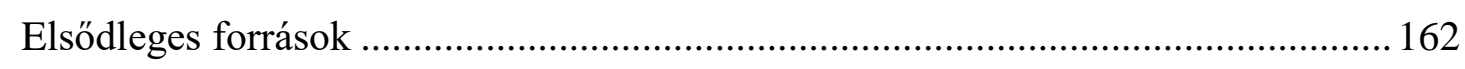

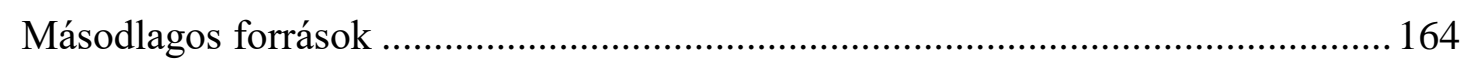

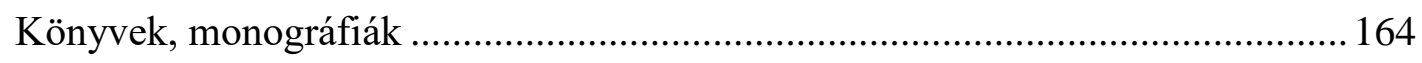




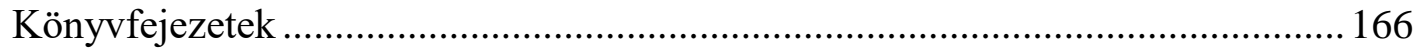

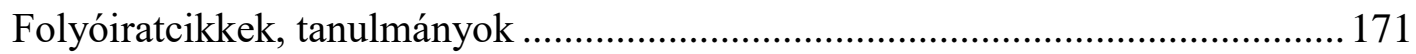

Nemzetközi szervezetek hivatalos oldalai, jelentései ........................................... 178

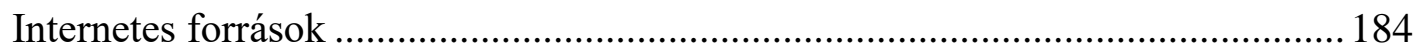

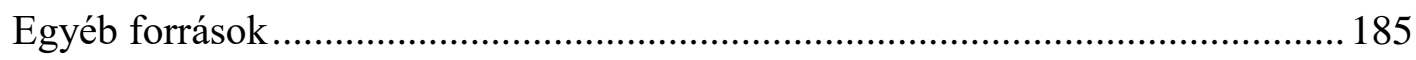

A szerző publikációi a disszertáció témájával kapcsolatosan ...................................... 193 


\section{TÁBLÁZATOK, ILLUSZTRÁCIÓK JEGYZÉKE}

1. ábra Az Aral-tó XX. századi vízgyüjtő területe

2. ábra Hogyan válik egy kérdés biztonsági kihívássá?.

3. ábra A vízmegosztás szempontjából meghatározó biztonságpercepciók KözépÁzsiában a három vizsgált időszakban 


\section{1. fejezet}

\section{BEVEZETÉS}

\subsection{Vízügyi kérdések a XXI. században}

Napjainkban egyre elfogadottabb nézetté válik, hogy az édesvíz lehet a XXI. század legfontosabb erőforrása, különösen a nemzetközi kapcsolatok alakulása

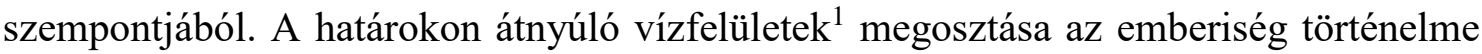
során mindig is nagy jelentőséggel bírt. Ezt bizonyítja többek között a Peter H. Gleick és társai által összeállított Vizügyi konfliktusok kronológiája (Water Conflict Chronology) (Gleick [2008]), amely több mint kétszáz vízmegosztással kapcsolatos konfliktus főbb jellegzetességeit írja le, illetve az Aaron T. Wolf által szerkesztett Nemzetközi édesvízi viták adatbázisa (Transboundary Freshwater Dispute Database) (Wolf [2013]), amely a határokon átnyúló vízfelületekkel kapcsolatos nemzetközi kooperáció előmozdításának érdekében gyüjt adatokat a vízigazgatási együttműködések és rezsimek történeti alakulásáról.

A nemzetközi kapcsolatok tudományterületének is fontos tárgyát képezi a vízmegosztással kapcsolatos események elemzése, ezek között is különösen a határokon átnyúló vízfelületek hatása az érintett államok között kialakuló konfliktusra és együttmüködésre nézve. A világon 263 olyan folyó, tó és vízgyüjtő terület található, melyen több ország osztozik - ez a Föld szárazföldi felszínének közel felét és a globális édesvízkészletek közel 60\%-át jelenti, a világ államainak pedig közel háromnegyedét (145 állam) teszi érintetté a vízmegosztás kérdésében (UN [2013]). 30 állam teljes kiterjedését tekintve ilyen területen fekszik. A Föld lakosságának közel 40\%-a él olyan vízgyüjtő területen, amely két vagy több állam határain nyúlik át, az emberiség 90\%-a pedig olyan országban él, amelynek határai között található államokon átívelő vízgyűjtő terület (UN-Water [2008], p. 1).

Ilyen körülmények között a vízkonfliktusok és a határon átnyúló vízkészletekkel kapcsolatos együttmüködések gyökereinek vizsgálata komoly gyakorlati fontossággal bírhat a nemzetközi kapcsolatok alakulása szempontjából, ezek elemzése a nemzetközi

\footnotetext{
${ }^{1}$ Kutatásomban a határon átnyúló vízfelületek definíciójához a "Convention on the Protection and Use of Transboundary Watercourses and International Lakes" c. nemzetközi jogi dokumentum alapvetéseit használom, miszerint határon átnyúló vízfelületnek minősül minden olyan felszíni vagy felszín alatti vízfelület, mely két vagy több állam határa mentén vagy határain keresztül folyik ("'Transboundary waters" means any surface or ground waters which mark, cross or are located on boundaries between two or more States").
} 
tanulmányok diszciplínájának fontos célterületét képezheti. Jelen kutatás ezen célterülethez, vagyis a vízmegosztással összefüggésben kialakuló nemzetközi konfliktusok és együttmüködések eredetének vizsgálatához kíván kapcsolódni.

\subsection{Hipotézisek és módszertan}

Kutatásom hipotézise, hogy a vízmegosztással összefüggö államközi kapcsolatok változásait a hidrológiai és a politikai-gazdasági-társadalmi kontextus változásait közvetítö, de egyúttal sok esetben önálló dinamikával is rendelkezö vízbiztonsági diskurzusok alakitják, ezért a statikus hidropolitikai elméletekkel szemben a konstruktivista megközelités egyértelmü hozzáadott értékkel rendelkezik ezek vizsgálatában. Tehát amellett érvelek, hogy a hidrológiai és a politikai-gazdaságitársadalmi kontextus, illetve föként az ezt magyarázó, jelentéssel felruházó vízbiztonsági diskurzusok független változóként befolyásolják a vízmegosztással összefüggő államközi kapcsolatok függő változóját. Feltételezem, hogy a vízügyi kérdések aligha értelmezhetőek mélységükben a konkrét politikai, gazdasági és társadalmi viszonyok ismerete nélkül. A dinamikusan változó vízbiztonsági diskurzusok pedig egyrészt ezen kontextuális hatások közvetítőiként jelennek meg, másrészt pedig, mivel ezen diskurzusok sok esetben nem közvetlenül kapcsolódnak a hidrológiai és politikai-gazdasági-társadalmi adottságokhoz, önmagukban is független változónak tekinthetőek, illetve képesek hatást gyakorolni a kontextus elemeire is.

Ezen hipotézist munkám során négy alhipotézis segítségével bizonyítom.

1. Első alhipotézisem (H1), hogy a vízmegosztással összefüggő államközi kapcsolatok változatosságát a materialista és statikus irányultságú racionalista elméletek (neorealizmus, neoliberalizmus) nem képesek mélyrehatóan vizsgálni.

2. Második alhipotézisem (H2), hogy a neorealizmus és a neoliberalizmus hiányosságainak kiküszöbölésére a konstruktivizmus megfelelő alapvetéseket és eszköztárat kínál a vízmegosztással összefüggő államközi kapcsolatok változatosságának vizsgálatára.

3. Harmadik alhipotézisem (H3) azt az előfeltevést tartalmazza, hogy a kialakuló vízbiztonsági diskurzusok egyrészt közvetítőként kapcsolódnak a politikai-gazdasági-társadalmi kontextushoz, másrészt önálló dinamikájuk révén független változóként is megjelenhetnek. 
4. Negyedik alhipotézisemben (H4) végül azt feltételezem, hogy a vízmegosztással összefüggő államközi kapcsolatok a vízbiztonsági diskurzusok változásai által befolyásolhatóak és alakíthatóak, tehát alapvető kiindulópontjukban különböznek a materialista és statikus irányultságú elméletektől, sokoldalú eszköztárat kínálva nemcsak a vízmegosztással összefüggő államközi kapcsolatok változatosságának elemzésére, hanem a felmerülő krízishelyzetek kezelésére, enyhítésére, megoldására is. Ezen feltételezés bizonyítása visszacsatol arra a kiindulási pontra, hogy a materialista, statikus irányultságú elméletek (neorealizmus, neoliberalizmus) nem képesek mélyrehatóan vizsgálni a vízmegosztással összefüggő államközi kapcsolatokat, és ezért a diskurzusokat elemezni képes konstruktivista megközelítés egyértelműen hozzáadott értékkel rendelkezik ezek tanulmányozásában.

Értekezésemben deduktív módszert alkalmazok, tehát az elméleti szakirodalom áttekintésére támaszkodva fogalmazom meg hipotéziseimet, melyeket a vizsgált gyakorlati esettanulmány alapján igazolok vagy vetek el a kutatás végén.

A kutatás során multidiszciplináris megközelítést használok, ami a földrajz, a hidrológia $^{2}$, a hidropolitika ${ }^{3}$, az etnográfia ${ }^{4}$, a nemzetközi jog, a biztonságpolitika és a történelem tudományterületeinek összekapcsolására épül. A kutatás alapsokasága, vizsgálódási bázisa a határon átnyúló folyókon elhelyezkedő alvízi és felvízi állampárok (diádok) közötti vízbiztonsági diskurzusok összessége. A kutatás elemzési egysége a határon átnyúló folyókon elhelyezkedő alvízi és felvízi állampárok (diádok) közötti vízmegosztással kapcsolatos vízbiztonsági diskurzusok és változó kontextusok két összehasonlítható esettanulmánya (Rogun vízerőmü-rendszer / TádzsikisztánÜzbegisztán diád, és Kambar-ata I. vízerőmü-rendszer / Kirgizisztán-Kazahsztán diád). A kutatás során a diádok mellett, illetve azok minél pontosabb elemzése végett az Araltó vízgyüjtő területe (ld. 1. ábra) is fontos szerepet játszik. Ezen régió államainak összessége ugyanis hidropolitikai biztonsági komplexumnak ${ }^{5}$ tekinthető, vízügyi kérdései tehát olyan szorosan kötődnek egymáshoz, hogy számos probléma csupán regionális keretekben értelmezhető.

2 A hidrológia a Föld vizeinek természetrajzával foglalkozó tudomány. Ld. Országos Vízügyi Főigazgatóság hivatalos honlapja. URL: http://www.ovf.hu/hu/hidrologia, letöltés ideje: 2015. október 2.

3 A hidropolitika "a határon átnyúló vízfelületekkel rendelkező államok közötti vízügyi konfliktus és együttmüködés szisztematikus tanulmányozása.” (Elhance [1999], p. 3).

4 Az etnográfia ,az emberek mindennapi életének vizsgálatára alkalmazott megközelítés, amely különös figyelmet fordít az adott kultúrára, azon folyamatokra, amelyek révén az emberek (néha vitázva vagy egyetértve) jelentést alkotnak." (Anderson-Levitt [2006], p. 279).

${ }^{5}$ A hidropolitikai biztonsági komplexumok elméleti hátterét bővebben tárgyalom a 2.4.4. fejezetben. 
A kutatás számbavételi egysége a választott esettanulmányokhoz kapcsolódó dokumentumok (adatbázisok, statisztikák, politikai dokumentumok és nyilatkozatok, nemzetközi egyezmények, etnográfiák, tudományos elemzések, nemzetközi szervezetek jelentései és állami hírügynökségek hírei) összessége, melyek alapján meghatározható a vízbiztonsági kontextusok és diskurzusok alakulása.

A kutatás három különböző konstruktivista módszertani eszköz alkalmazásával igyekszik bemutatni az elmélet magyarázó erejét és hozzáadott értékét a vízmegosztással összefüggő államközi kapcsolatok változatosságának tanulmányozásában. Az első kiválasztott módszer az etnográfia, ami a konstruktivizmusra jellemző széleskörü leírások révén mutatja be a vizsgált társadalom jellegzetességeit. Az etnográfiai módszer segítségével feltárható és elemezhető a politikai-gazdasági-társadalmi kontextus, és annak a kialakult vízmegosztási diskurzusokkal való kapcsolata. Ezáltal láthatóvá válik, hogy a kontextus alapvetően közvetetten, a konstruktivizmus eszköztárával vizsgálható diskurzusokon keresztül befolyásolja a vízmegosztással összefüggő államközi kapcsolatok változatosságát, nagyrészt a vízkészletekhez társadalmilag, interszubjektíven társított jelentéstartalmak alakítják a diskurzus konfliktusra vagy együttmüködésre irányuló voltát.

A második kiválasztott módszer az összehasonlító folyamatkövetés, melynek fő célja ok-okozati összefüggések tudományos igényü feltárása és elemzése, amit időszakonkénti és területenkénti összehasonlításban valósítok meg. Értekezésemben ezt a módszert a vízügyi kérdések biztonságiasítási folyamatának vizsgálatára alkalmazom. Három jellegzetes korszakban, a szovjet időszak 1960-tól 1990-ig tartó szakaszában, az 1991-től 1999-ig tartó együttműködési periódusban, és a növekvő feszültségeket hozó 2000-es években vizsgálom a határon átnyúló vízfelületekhez társított, biztonsággal kapcsolatos jelentéseket a Közép-Ázsia területén egyértelműen hangsúlyos, és a vizsgált diádok esetében is meghatározó alvízi-felvízi törésvonalak mentén, összekapcsolva a biztonságiasítás folyamatát a domináns biztonságértelmezések szektorális besorolásával. Ezen módszertan segítségével megerősítem, hogy a politikai-gazdasági kontextus alapvetően közvetetten, vagyis a vízkészletekhez társított jelentéstartalmak révén befolyásolja a biztonságiasítási folyamat, vagyis a konfliktus és együttmüködés alakulását. Az esettanulmány ebben a fejezetben arra is lehetőséget nyújt, hogy bemutassam, hogy a diskurzus önmagában is müködhet független változóként, a kontextustól függetlenül, illetve akár attól eltérően alakítva a vízmegosztással összefüggő államközi kapcsolatokat. 
Első két választott módszerem tehát alátámasztja, hogy a politikai-gazdaságitársadalmi kontextus a vízbiztonsági diskurzusok révén, vagyis a társadalmilag konstruált jelentéstartalmak által is befolyásolja a vízmegosztással összefüggő államközi kapcsolatok változatosságának alakulását, illetve, hogy a diskurzusok a kontextustól függetlenül is képesek lehetnek erre. Felmerülhet azonban a kérdés a diskurzusok kapcsán, hogy valóban megtörténik-e ez a jelentéstársítás? Végbemennek-e valójában ezek a folyamatok, és ha igen, hogyan lehet vizsgálni a vízbiztonsági diskurzusok alakulását? A harmadik kiválasztott módszer célja annak bizonyítása, hogy a vízbiztonsági diskurzusok alakulása közvetlenül megvizsgálható, és ezek rekonstruálása alátámasztja az etnográfiai módszer és az összehasonlító folyamatkövetés révén már bemutatott folyamatokat. Harmadik módszerem tehát a diskurzuselemzés, amelynek során a diskurzus elsődleges közvetítő eszközeit vizsgálva bizonyítom eddigi állításaimat, a korábban alkalmazott három időperióduson belül, nemzetközi jogi dokumentumok, tudományos összefoglalók, illetve a közép-ázsiai állami hírügynökségek orosz és angol nyelvü hírei révén. A választott dokumentumcsoportok lehetővé teszik számomra, hogy a három különböző forrástípust egybevetve vizsgáljam meg, hogy az elemzett dokumentumok inkább konfliktust, vagy inkább együttmüködést reprodukáló domináns diskurzust rögzítenek-e az adott államok vízbiztonsággal összefüggő államközi kapcsolataira vonatkozóan.

A kutatás során primer adatgyüjtésre nem kerül sor, az elemzések meglévő adatbázisok, statisztikák, politikai dokumentumok és nyilatkozatok, nemzetközi egyezmények, etnográfiák, tudományos elemzések, nemzetközi szervezeti jelentések és állami hírügynökségi hírek másodelemzésén alapulnak, melyek alapján következtetéseket vonhatok le az adott időszakokban a vízbiztonsági diskurzusok és a hidrológiai, illetve politikai-gazdasági-társadalmi kontextus összefüggéseivel kapcsolatban. Másrészt diskurzuselemzést végzek a felsorolt szövegeken, mely által rekonstruálom az adott időszakokban kialakult vízbiztonsági diskurzusokat, és ezek kapcsolatát a hidrológiai, illetve politikai-gazdasági-társadalmi kontextussal.

Esettanulmányaimat szakértői minta alapján választottam ki a kutatás céljait és hipotézisét figyelembe véve. A kiválasztásnál arra törekedtem, hogy a két eset bemutassa a politikai-gazdasági-társadalmi kontextus változásainak, a vízbiztonsági diskurzusok alakulásának, illetve az államközi konfliktus és az együttmüködés dinamikájának összefüggéseit a XX. században és a XXI. század elején. Ezek kiválasztásához az Aaron T. Wolf által szerkesztett Nemzetközi édesvizi viták adatbázisát (Transboundary Freshwater Dispute Database) használtam fel, melynek 
segítségével azonosítani tudtam a kritériumoknak megfelelő diádokat. Ezek közül a kutatásom hipotéziseit figyelembe véve választottam ki két esettanulmányomat, ügyelve arra, hogy ezek minden tekintetben (hidrológiai, politikai, gazdasági, társadalmi) hasonlóak legyenek, csupán a vízbiztonsági diskurzusok fö irányát tekintve térjenek el (konfliktus versus együttmüködés), annak érdekében, hogy mindkét statikus elmélet cáfolatát bemutathassam. Ez a mintavételi folyamat vezetett a Rogun vízerömürendszer (Tádzsikisztán-Üzbegisztán diád, Amu-darja, konfliktus) és a Kambar-ata I. vízerőmü-rendszer (Kirgizisztán-Kazahsztán diád, Szir-darja, együttműködés) eseteinek kiválasztásához. A választott diádok a közép-ázsiai hidropolitikai biztonsági komplexum tagjai, ${ }^{6}$ a térség általános vízügyi folyamatainak bemutatása ezért az elemzés elválaszthatatlan részét képezi. A vizsgálat időhorizontja egyrészt keresztmetszeti, 1960. január 1-től 2010. december 31-ig terjed ki, a diskurzuselemzés esetében egy 2016. augusztus 15-ig terjedő kiegészítő fejezettel, másrészt kiegészül a megértéshez nélkülözhetetlen történeti visszatekintéssel is.

\subsection{Az értekezés szerkezete és a felhasznált szakirodalom áttekintése}

Hipotézisem bizonyításához először is a releváns elméletek áttekintése szükséges. A bevezetést és a módszertani alapvetéseket követően értekezésem második fejezete ezt tűzi ki célul. Az elméleti áttekintést a 2.1. alfejezetben a vízmegosztás és a vízbiztonság egyre növekvő globális jelentőségének hangsúlyozásával, a releváns adatok, statisztikák áttekintésével vezetem be, alátámasztva azon, a bevezetésben tett állításomat, hogy a nemzetközi kapcsolatok tudományágán belül egyre nagyobb fontossággal bír egy széles körben alkalmazható hidropolitikai elméleti keret kialakítása. Ezen adatok és statisztikák forrásai a vízügyi kérdésekkel foglalkozó állami kutatóintézetek és nemzetközi szervezetek által kiadott jelentések és összefoglalók, különösen az ENSZ (UNU-INWEH [2015], WHO-UNICEF [2014]), ezen belül is a UN-Water [2013a], [2013b], [2013c], [2013d] együttmüködés részéről, de ezek mellett felhasználom az ENSZ Éghajlatváltozási Kormányközi Testülete (Intergovernmental Panel on Climate Change, IPCC) [2008], a World Water Assessment Programme [2012], [2014], a U. S. Geological Survey [2015], a Világgazdasági Fórum (World Economic Forum, WEF) [2015], illetve a több nemzetközi nagyvállalat által létrehozott 2030 Water Resources Group (WRG) [2009] dokumentumait is.

${ }^{6}$ A közép-ázsiai hidropolitikai komplexum ötödik állama, Türkmenisztán nem képezi értekezésem tárgyát. Ennek oka, hogy az állam rendkívül befelé forduló, elzárkózó politikát folytat, aminek következtében kevés megbízható adat áll rendelkezésre vízügyekről kialakított álláspontját illetően. 
Ezek után a 2.2. alfejezet a már létező hidropolitikai elméleti törekvéseket, kísérleteket tekinti át, felhívva a figyelmet azok korlátaira és hiányosságaira. Ehhez David LeMarquand [1977], Anton du Plessis [2000], Kathryn Furlong [2006], valamint Jeroen F. Warner és Mark Zeitoun [2008] tanulmányait használom fel. Mivel a kutatás középpontjában a vízmegosztással összefüggő államközi kapcsolatok változatossága, illetve az ennek kialakulását lehetővé tevő dinamikus vízbiztonsági diskurzusok állnak, materialista beállítottságuk és statikusságuk miatt sem a neorealista neo-malthusiánus (2.3.1. alfejezet), sem a neoliberális bőségszaru-megközelítésen alapuló (2.3.2. alfejezet) elméleti irányzatok nem biztosítják a megfelelő fókuszt és elemzési keretet ezek feldolgozására. Ezt a hidropolitika két fő hagyományos megközelítésének (neomalthusiánus és bőségszaru-megközelítés, ld. Susanne Schmeier [2010]) kritikájával támasztom alá, melyet a 2.3.3. alfejezetben ismertetek. A neo-malthusiánusok esetében Miriam Lowi és Jay Rothman [1993], Norman Myers [1993], Thomas Naff [1994], Peter H. Gleick [1993], [2010], Thomas Homer-Dixon [1994], [1999], Arnon Soffer [1999], Carius et al. [2004], Mark Zeitoun és Jeroen F. Warner [2008] és Martin Kipping [2009] munkáit vizsgálom meg, míg a bőségszaru-megközelítés fő képviselőiként Aaron T. Wolf [1995], [1998], Helga Haftendorn [2000], Tony Allan [2001], [2002], [2003], Wolf és munkatársai [2003], Jerome Delli Priscoli és Wolf [2009], valamint Sandra Postel és Wolf [2009] munkásságát tekintem át.

Mindezen elméleti alapvetések mentén bizonyítom első alhipotézisemet, miszerint a vízmegosztással összefüggő államközi kapcsolatok változatosságát a materialista és statikus irányultságú racionalista elméletek (neorealizmus, neoliberalizmus) nem képesek mélyrehatóan vizsgálni, illetve levonom a következtetést, hogy ezért ezek elemzéséhez egy, a neorealizmus és a neoliberalizmus hiányosságait is kiküszöbölö elmélet szükséges.

Értekezésemben mindkét megközelítés hiányosságainak feloldására a konstruktivista elméleti keret alkalmazása mellett érvelek, ezért a konstruktivizmus mint nemzetközi politikaelméleti iskola alapvetéseinek áttekintésére is szükség van a kutatás széleskörü célkitüzéseinek megalapozása érdekében. Az ezt tárgyaló 2.4. alfejezetben általánosságban elemzem a konstruktivista megközelítés jellemzőit Emanuel Adler [1997], [2012], Alexander Wendt [1995], [1999], Jeffrey C. Alexander [1995], Steve Smith [1996], [1997], Christian Reus-Smit [2005], Ian Hurd [2008], Xymena Kurowska és Friedrich Kratochwil [2012], valamint Kiss J. László [2009] munkásságának segítségével, A konstruktivista elméletek két fó ágazata közül a konvencionális konstruktivizmus (2.4.1) mellett köteleződöm el, melyet Ted Hopf [1998], Robert 
Jackson és Georg Sorensen [2006], Jeffrey T. Checkel [2008], Kiss J. László [2009], valamint Marton Péter és munkatársai [2015] munkái segítségével ismertetek. Kutatásom során ezen irányzat elképzelései mentén alkalmazom három választott módszertani keretemet az esettanulmányaim elemzéséhez.

A konstruktivizmus általános alapvetéseinek elemzése után a 2.4.2. alfejezetben megvizsgálom ezek relevanciáját a vízmegosztással összefüggő államközi kapcsolatokban, melyben különösen Frédéric Julien [2012] úttörő jellegü tanulmánya lesz segítségemre. A fejezetben Julien mellett Julie Trottier [2008], valamint Mark Zeitoun és Naho Mirumachi munkásságát is felhasználom. A konstruktivista elméleti kereten belül főként a koppenhágai iskola biztonságiasításhoz kapcsolódó előfeltevései képezik majd elemzésem alapját, amiket a 2.4.3. alfejezetben tárgyalok. Barry Buzan és szerzőtársai, Ole Wæver és Jaap de Wilde [1998] szerint a biztonságiasítás „ami a politikát az általánosan véve elfogadott játékszabályokon túlra viszi, és az adott kérdést így egy rendkívül speciális politikaterületként, vagy a politika fölött álló problémaként jeleníti meg” (Buzan et al. [1998], p. 23), tehát a politika szférájából, ahol a kérdések demokratikusan tárgyalhatóak, átemeli az adott problémakört a biztonság szférájába, ahol a túlélés érdekei felülírnak minden egyéb megfontolást. Buzan és szerzőtársai szerint tehát nem létezik olyan problémakör, amely önmagában véve biztonsági kérdés, konfliktus vagy együttmüködés tárgya lenne - ennek eldöntése elméletük szerint az adott helyzetben jelenlévő biztonsági diskurzusok függvényében alakul, amit a politikai vezetők által meghatározott irányvonalak, a társadalom helyzetét befolyásoló tényezők, illetve az intézkedésekhez szükséges gazdasági és társadalmi erőforrások megléte befolyásol. A biztonságiasítás elméletén túl egy újszerü, napjainkig kevés alkalommal felhasznált elméleti fogalom, a hidropolitikai biztonsági komplexum is lehetővé teszi a koppenhágai iskola és a vízügyi kérdések vizsgálatának összekapcsolását, amit a 2.4.4. alfejezetben tárgyalok.

Értekezésem elméleti alapvetéseinek tisztázása ezzel véget ér, a 3. fejezettől kezdődően az esettanulmányok elemzésén keresztül foglalkozom hipotéziseim bizonyításával. Ehhez először is szükséges a vizsgált térség, a közép-ázsiai hidropolitikai biztonsági komplexum hidrológiai jellemzőinek bemutatása (3.1. alfejezet). Ehhez Daene McKinney [2004], Amber Brown és Marty D. Matlock [2011], Shlomi Dinar [2012], Thomas Bernauer és Tobias Siegfried [2012], valamint Ilkhomjon Niyazov et al. [2012] munkáit használom fel. Ezek mellett nemzetközi szervezetek elemzéseire (ICG [2002], [2014], ICWC [2015], Világbank [2013]) és adatbázisokra 
(UNEP [2008], UNESCO [2012]), CAWATERinfo [2012], FAO Aquastat adatbázis, [2014a], [2014b], [2014c], [2014d] támaszkodom.

A 3.2. alfejezet Közép-Ázsia államainak vízbiztonsági helyzetét tárgyalja, melyhez a már említett forrásokon túl Jeremy Allouche [2004], [2007], Shairbek Juraev [2012], valamint Iskandar Abdullaev és Shavkat Rakhmatullaev [2015] munkáit, illetve a CIA World Factbook, az Eurasianet, az ENVSEC [2011], a GWP CACENA [2011], az IHA [2013] és a helyi állami szervek adatait is felhasználom.

Értekezésem 3.3. alfejezetében a Rogun és a Kambar-ata I. vízerőmű-rendszerek esettanulmányait vizsgálom meg, fóként a Világbank és az Eurázsiai Fejlesztési Bank adatait felhasználva. A Rogun gát és a hozzá tartozó vízerőmü Tádzsikisztánban, a $V{ }^{7}{ }^{7}$ folyón épül, az építkezés hosszabb-rövidebb megszakításokkal évtizedek óta folyamatban van. A gát és a vízerőmü üzembe helyezése azonban befolyásolná az Amudarja vízhozamát, ami hátrányosan érinti az alvízi Üzbegisztán és Türkmenisztán érdekeit. Üzbegisztán ezért többször fenyegette már meg Tádzsikisztánt, akár fegyveres beavatkozást is kilátásba helyezve, a kérdés tehát egyértelmüen negatív hatással van a két állam vízbiztonsággal összefüggő kapcsolataira. A Kambar-ata I. gát és a hozzá tartozó vízerőmü építése szintén évtizedekkel korábban, már 1986-ban megkezdődött Kirgizisztánban, a Narin folyón. Ezt a munkát most orosz segítséggel tervezik újraindítani. A gát és vízerőmü megépítése a Szir-darja folyó vízhozamát változtatná meg, ami Kazahsztán és Üzbegisztán érdekeit sérti. Üzbegisztán ebben az esetben is ellenséges, konfliktusos politikát folytat, Kazahsztán azonban, hosszas tárgyalások után, együttmüködésre hajlik a kérdésben. Mindezek okainak feltárására a U.S. Energy Information Administration [2013], a Világbank [2014a], [2014b], [2014c], a Human Rights Watch [2014], valamint az International Crisis Group [2002], [2014] jelentéseit, illetve Andriy Demydenko [2004], Kai Wegerich [2008], Anvar Rahmetov [2009], Roman Muzalevsky [2010], Dobrovits Mihály [2011], Raushan Nurshayeva [2012], Shlomi Dinar [2012], Eli Keene [2013], Murat Sadykov [2013], Fernando Garcés de los Fayos [2014], Amanda E. Wooden [2014], és Filippo Menga [2014] munkáit használom fel.

Látható, hogy a két eset hasonló kontextusban jött létre alvízi és felvízi államok között, ennek ellenére azonban az államközi kapcsolatokra gyakorolt hatás különböző: az első esetben egyre konfliktusosabb tendenciák mutatkoznak, míg a második esetben az együttműködés irányába történnek lépések. Ezen folyamatok elemzésével részben

\footnotetext{
${ }^{7}$ A megfelelö átírási forma Vakhs lenne, de a magyar szakirodalomban a folyó neve Vahsként (illetve néhány esetben Vaksként) honosodott meg.
} 
bizonyítom harmadik alhipotézisemet, miszerint a kialakuló vízbiztonsági diskurzusok egyrészt közvetítőként kapcsolódnak a politikai-gazdasági-társadalmi kontextushoz, másrészt önálló dinamikájuk révén független változóként is megjelenhetnek.

Az elméleti alapvetéseknek és az esettanulmány kontextusának meghatározását követően a konstruktivizmus három jellegzetes módszertani eszközének gyakorlati alkalmazásával igazolom további alhipotéziseimet. A 4. fejezet az etnográfiai módszer, az 5. fejezet az összehasonlító folyamatkövetés, a 6. pedig a diskurzuselemzés eszközeivel vizsgálja meg a 3. fejezetben részletesen leírt esettanulmányi kontextust, vagyis bővebben a közép-ázsiai hidropolitikai biztonsági komplexum, szükebb értelmezésben pedig a Rogun és Kambar-ata I. vízerőmü-rendszerek eseteit az egyértelmüen hangsúlyos alvízi-felvízi törésvonalak mentén.

Mindehhez szükségesnek tartom minden alfejezet elején részletesen ismertetni a kiválasztott három módszertan főbb jellegzetességeit. Az etnográfiai módszer nemzetközi kapcsolatokban való konstruktivista alkalmazása egy viszonylag új jelenség, ami új lendületet adhat a diszciplína fejlődésének, újfajta és széleskörü információtartalommal látva el azt az esettanulmányok szintjén, melynek révén az elmélet és a valós gyakorlat közelebb kerülhet egymáshoz. A módszer részletes ismertetéséhez Hugh Gusterson [2008], Mark B. Salter [2013] és Wanda Vrasti [2008] müveit használom fel. A folyamatkövetés olyan kvalitatív módszer, mely ok-okozati összefüggések feltárásával, azok logikájának felvázolásával vezeti el a kutatót a hipotézisek bizonyításához vagy cáfolatához. Bemutatásához Alexander L. George és Andrew Bennett [2005], Jeffrey T. Checkel [2008], David Collier [2011], valamint Andrew Bennett és Jeffrey T. Checkel [2012] munkáit használom fel. A harmadik választott módszerem a diskurzuselemzés, melynek lényegét fentebb már ismertettem. Ezt a módszert Terrell Carver [2002], Szabó Márton [2003], Iver B. Neumann [2008], James Paul Gee [2011], valamint Virág Attila [2014] munkássága segítségével mutatom be. Amennyiben a három konstruktivista jellegü módszertan alkalmazásával hozzáadott értéket tudok bemutatni az elemzés területén a neorealizmus és a neoliberalizmus hiányosságainak kiküszöbölésére, bizonyítást nyer második alhipotézisem, miszerint a konstruktivizmus megfelelő alapvetéseket és eszköztárat kínál erre. Az összehasonlító folyamatkövetés és a diskurzuselemzés során részletesen is feltárom a koppenhágai iskola biztonságiasítás-elméletének gyakorlati vonatkozásait, ami végül a biztonságiatlanítás fogalmának alkalmazásán keresztül elvezet negyedik alhipotézisem bizonyításához is. Eszerint a vízmegosztással összefüggő államközi kapcsolatok a vízbiztonsági diskurzusok változásai által befolyásolhatóak és alakíthatóak, tehát 
alapvető kiindulópontjukban különböznek a materialista és statikus irányultságú elméletektől, sokoldalú eszköztárat kínálva nemcsak a vízmegosztással összefüggő államközi kapcsolatok változatosságának elemzésére, hanem a felmerülő krízishelyzetek kezelésére, enyhítésére, megoldására is.

Értekezésem nyolcadik fejezete a kutatás eredményeinek összegzését és a következtetések levonását tartalmazza, illetve ajánlásokat is megfogalmaz. Az esettanulmányok következtetéseinek összefoglalása után a várható eredmény a következő: mindhárom konstruktivista jellegü módszertan alkalmazása megmutatja, hogy a konfliktus és együttműködés Közép-Ázsiában a hidrológiai okok és a politikaigazdasági-társadalmi kontextus közvetlen hatása mellett a társadalmi interakciók, különösen a kialakuló diskurzusok révén alakul ki, mely utóbbi nemcsak közvetíti, de befolyásolhatja is a politikai-gazdasági-társadalmi kontextus alakulását. A legjelentősebb elem a konstruktivista keret hozzáadásával tehát az, hogy nem egyirányú folyamatokat vizsgál, hanem kölcsönhatások értelmezését és elemzését teszi lehetővé, mely által teret ad a neorealista és neoliberális elméletek révén determinisztikus változóként megjelenített politikai-gazdasági-társadalmi kontextus elemeinek megváltoztatására. Mindezek alapján egyesével értékelem alhipotéziseimet, majd a hipotézis egészére nézve kísérlem meg a következtetések levonását.

Az értekezés újdonsága egyrészt a hidropolitikai elméleti szakirodalomhoz való hozzájárulásában, másrészt módszerében, harmadrészt pedig témájában található. Bár a konstruktivista elméleti keret nemzetközileg egyre inkább fóáramúnak tekinthető (Adler [2012]), ritka és kevés az ezen elméleti iskola fejlődésében, az elméleti keretek tesztelésében való magyar részvétel. Mint már említettem, a hidropolitika szakterülete számos, egyre szélesebb körű és mélyebb elemzést tudhat magáénak, az elméleti háttérrel való összekapcsolás azonban csak kevés esetben jellemző, ezen munkák általában a gyakorlatra összpontosítanak. A konstruktivista elméleti megközelítés alkalmazása a vízmegosztással összefüggő államközi kapcsolatok elemzésében már nem nevezhető újnak, Julien Frédéric úttörő jellegű műve már 2012-ben megjelent, az elmélet alkalmazása és tesztelése azonban mindezidáig csak kevés alkalommal történt meg a nemzetközi tudományos életben is. Bár Magyarország felzárkózóban van a nemzetközi tudományos élethez a konstruktivista elméletek alkalmazásának tekintetében, az is elmondható, hogy a jelen értekezéshez hasonló elméleti kutatások körének tovább növelése fontos célkitűzés lehet a magyar akadémiai szférában.

Az alkalmazott három konstruktivista módszer tekintetében kijelenthető, hogy Magyarországon ezek tudatos alkalmazása a nemzetközi kapcsolatok tudományágán 
belül ritka, triangulációjukra pedig nincs korábbi példa, annak ellenére sem, hogy a három felhasznált módszer kiválóan kiegészíti egymást, alátámasztva vagy cáfolva egymás következtetéseit.

A téma tekintetében elmondható még, hogy a közép-ázsiai hidropolitikai komplexum kapcsán Magyarországon inkább ismeretterjesztő cikkek jelennek meg. Ágó Ferenc munkássága az egyetlen számottevő szakmai forrás, mely a térség legújabb kori történetének vízmegosztási kérdéseire koncentrál, a kérdés vizsgálata viszont nemcsak a magyar tudományos élet, hanem a magyar külgazdasági kapcsolatok szempontjából is nagy jelentőséggel bírhat.

Jelen értekezés tehát több újdonsággal is szolgál, különösen magyar szempontból. Egyrészt elméleti keretbe kíván helyezni egy fontos hidropolitikai kérdést, a vízmegosztással összefüggő konfliktus és együttmüködés alakulásának változatosságát, másrészt bővíteni szeretné a magyar nyelvű konstruktivista elméleti kutatások körét, harmadrészt pedig hozzájárul a konstruktivizmushoz kapcsolódó három felhasznált módszer alkalmazásához és teszteléséhez a vízmegosztással összefüggő államközi kapcsolatok esetében. Gyakorlati témája és esettanulmánya az elméleti újdonságok mellett is említést érdemel a nóvumok között. Közép-Ázsia ugyanis egy, a tudományos életben sokszor méltatlanul elhanyagolt térség, amihez történelmi kötelék füzi a magyarságot, és hangsúlyos stratégiai érdek a nemzetközi közösség nagyhatalmait - belső dinamikájának feltárása így nemcsak elméleti, de gyakorlati szempontból is nagy fontossággal bír a nemzetközi kapcsolatok diszciplínájában. 


\section{VÍZÜGYI KÉRDÉSEK A NEMZETKÖZI KAPCSOLATOK ELMÉLETÉBEN}

„A víz: politika - és ez az állítást aligha kell megvédeni” - jelentette ki Peter P. Mollinga hidropolitikai szakértő 2001-es tanulmányában, azon megjegyzések kapcsán, melyek szerint a vízügyi kérdések egyre nagyobb szerepet kapnak a nemzetközi kapcsolatokban (Mollinga [2001], p. 733). A határon átnyúló vízfelületek szerepe az államközi konfliktusok kialakulásában már évtizedek óta fontos témáját képezi a nemzetközi kapcsolatok elméletének, csakúgy, mint annak kérdése, hogy hogyan befolyásolják a megosztott vízkészletek az országok közötti együttmüködést. A vízügyekkel kapcsolatos konfliktus és együttmüködés vizsgálata az 1970-es évek végén életre hívta a hidropolitika tudományágát (ld. LeMarquand [1977]). A hidropolitika ,a határon átnyúló vízfelületekkel kapcsolatos kérdések miatt kialakuló államközi konfliktus és együttmüködés szisztematikus vizsgálata" (Elhance [1999], p. 3). Jelen fejezet ezen szisztematikus vizsgálat elméleti hátterének már kialakult és még kialakulóban lévő változatait mutatja be, a konstruktivista elméleti megközelítés alkalmazása mellett érvelve.

\subsection{Vízbiztonság: a XXI. század egyik legfontosabb kihívása ${ }^{8}$}

A vízügyi kérdések elméleti hátterének jelentőségét a nemzetközi kapcsolatok tudományága számára a vízbiztonság gyakorlati kérdésének ismertetésén, napjaink egyre aggasztóbbá váló vízügyi tendenciáin és az ezekhez kapcsolódó globális kihívások bemutatásán keresztül érthetjük meg igazán. Földünk felszínének 71\%-át víz borítja, ami $1386000000 \mathrm{~km}^{3}$-nyi, tehát emberi mértékkel szinte elképzelhetetlen mennyiséget jelent (USGS [2015]). Ez a vízmennyiség alapjában véve állandónak tekinthető, a víz folyamatos körforgása révén ugyanaz a vízkészlet jut el a Föld jelenlegi lakosságához, mint ami a korábbi földtörténeti korokban, az ember kialakulása előtt is létezett már (National Geographic [2015]). Ezáltal azonban a népesség növekedése révén az egy före jutó megújuló vízkészletek folyamatosan csökkennek. Glied Viktor elemzése szerint a megújuló vízkészletek tekintetében évente $1700 \mathrm{~m}^{3}$ a fejenként

${ }^{8}$ A fejezet anyaga kis változtatásokkal publikálásra került a következő formában: Szálkai Kinga [2015]: „Vízkészleteink jövője: Mit tehet az ENSZ vízbiztonságunk érdekében? (1).” AJRC Elemzések, URL jelenleg nem elérhetö. 
rendelkezésre álló ivóvíz mennyisége, amely mennyiség a legtöbb szakértő véleménye szerint elvben elegendő a világ népességének ellátására (Glied [2009], p. 7). Ennek ellenére számos előrejelzés foglalkozik a vízszükösség várható hatásaival, illetve napjainkban a gyakorlatban is egyre inkább megfigyelhetőek ennek súlyos következményei.

A vízkészletek relatív csökkenése több okra vezethető vissza. Ezek közül a növekvő vízfelhasználás többek között a már említett népességnövekedés következménye. A Föld népessége 2011-ben elérte a hétmilliárdot, és 2050-re a kilencmilliárdot is meghaladhatja. Becslések szerint 2000 és 2025 között 30\%-kal nő a népesség. E növekedés nagy része a fejlődő országokban következik be, melyek jelentős hányadában a vízkészletek mennyisége, illetve a vízigazgatás hatékonysága miatt már 2000-ben is problémák merültek fel a lakosság vízigényének kielégítése kapcsán (UNUINWEH [2015], p. 22). Emellett a vízhiányból következően az élelmiszerbiztonság is veszélybe kerülhet, becslések szerint 2030-ra 50\%-kal nőhet az élelmiszerek iránti kereslet (UN-Water [2013a]).

A népességszám növekedése mellett az élelmiszerek és más fogyasztási javak előállítása is egyre nagyobb vízfelhasználást igényel. Az elmúlt évszázadban a vízfelhasználás a népességnövekedés arányának kétszeresével nőtt (UN-Water [2013b]). A mezőgazdaság igényei jelenleg a világ vízfelhasználásának 70\%-t teszik ki, ez az arány azonban a fogyasztási szokások változása miatt várhatóan még tovább növekszik majd, a vízigényes tejtermékek és húskészítmények fogyasztása ugyanis arányaiban véve emelkedik. A számottevő vízfelhasználással járó mezőgazdasági technológiák közül a legjelentősebb az öntözéses gazdálkodás, az ilyen módszerrel müvelt területek kiterjedése az 1970-es 170 millió hektárról 2008-ra 304 millió hektárra nőtt - a növekedés pedig várhatóan folytatódik (WWAP [2012], p. 13). E tényezők révén becslések szerint 2050-re a jelenlegi felhasználás közel 20\%-ával nőhet a mezőgazdaság vízfogyasztása (UN-Water [2013a]).

Mindezen túl a vízigazgatás területén a nem hatékony vízfelhasználás és a vízszennyezés is az elérhető és elfogadható minőségü vízkészletek relatív csökkenéséhez vezet. A fejlődő országokban a szennyvíz közel 90\%-a tisztítatlanul jut a természetes vizekbe és a parti zónákba, ezzel veszélyeztetve nemcsak az egészséges környezetet és az ivóvízkészleteket, hanem az élelmiszerbiztonságot és a biodiverzitást is. Az édesvízi ökoszisztémák a leginkább veszélyeztetettek a világon, itt következett be mindezidáig a legnagyobb pusztulás (UN-Water [2013c]). 1960-ban az édesvízi és parti ökoszisztémák között kevesebb, mint 24 számított „halott zónának,” míg napjainkra ez 
az érték 500-ra emelkedett (World Resources Institute [2015]). Az energiatermelés is befolyásolja a vízminőséget, az ipari folyamatok során felszabaduló kémiai, biológiai, radioaktív vagy hőszennyezés rendkívül káros következményekkel járhat a lokális és regionális ökoszisztémára nézve (WWAP [2012], p. 15).

A rendelkezésre álló vízkészletek relatív csökkenését az eddig felsorolt tényezőkön túl a klímaváltozás is befolyásolja. Az ENSZ Éghajlatváltozási Kormányközi Testülete (Intergovernmental Panel on Climate Change, IPCC) 2008-as jelentésében kifejtette, hogy a klímaváltozás elleni küzdelem nagyrészt a vízigazgatás kérdéseiről szól; a vízügyi kérdések alkotják az összekötő láncszemet, melyen keresztül a klímaváltozás hatásai közvetlenül érintik az emberiséget (WWAP [2014], p. 7). Az atmoszféra hőmérséklet-emelkedésének hatására a víz hőmérséklete megemelkedik, a csapadék mennyiségében változások következnek be, a viharok intenzitása megnő, tengerszint-emelkedés következik be, és a vizekhez kapcsolódó ökoszisztémák is megváltoznak (U.S. Environmental Protection Agency, Office of Water [2012], p. 5).

A klímaváltozás és a vízügyi kérdések összekapcsolódásának egyik jellemző mutatója a szélsőséges időjárási jelenségek hatása a társadalomra: 1991 és 2000 között több mint 665000 ember vesztette életét 2557 természeti katasztrófa során, melyek 90\%-a vízügyekhez kapcsolódott (UN-Water [2013d]). Egy másik jellemző jelenség, hogy az egyébként is túlságosan nagy vagy kis mennyiségü vízkészletek problémája a klímaváltozás révén súlyosbodik, tehát megnő az árvizek vagy száraz időszakok száma, illetve intenzitása (IPCC [2008], p. 7). Az IPCC előrejelzése szerint a 2070-es évekre a vízszükösség már Kelet- és Dél-Európát is igen súlyosan fogja érinteni, 44 millió fő szenved majd a klímaváltozás és a vízügyi kérdések összefonódása révén kialakult vízstressztől, ami a vízenergia-termelést is jelentősen befolyásolja majd (UN-Water [2013a]). A klímaváltozáshoz kapcsolódó költségbecslések nagy része is az elegendő vízkészletek biztosításához és az árvízvédelemhez szükséges forrásokkal kalkulál. A Világbank szerint egy 2 Celsius-fokos globális átlaghőmérséklet-emelkedés vízügyekkel kapcsolatos költségei 13,7 milliárd és 19,2 milliárd USD-re tehetőek (UNWater [2013a]).

Mindezen tényezők révén az egy före jutó ténylegesen felhasználható vízkészletek olyan mértékben csökkennek, hogy a Világgazdasági Fórum (World Economic Forum, WEF) 2015-ben kiadott jelentése a vízkészletekkel kapcsolatos válságokat jelölte meg elsőként a társadalomra legjelentősebb hatást gyakorló globális kockázati tényezők között, míg annak valószínűségét tekintve, hogy ilyen jellegü probléma bekövetkezik-e a következő tíz évben, ugyanez a kockázat a szintén előkelő 
nyolcadik helyen áll. Ennek alapján tehát az elkövetkező évtizedben a világnak szembe kell néznie azzal, hogy a vízkészletek elérhetőségének biztosítása nagy valószínűséggel fontos globális biztonsági kihívássá válhat. A jelentésben megemlített kockázati tényezők között egyébként a klímaváltozáshoz való alkalmazkodás, a szélsőséges időjárási jelenségek, az ember által kiváltott természeti katasztrófák kockázata, az élelmiszerbiztonság és a fertőző betegségek terjedése is szorosan kapcsolódik a vízügyi kérdésekhez (World Economic Forum [2015]).

Már a napjainkban mért adatok is egyértelműen mutatják, hogy komoly problémákat okoz a vízkészletek relatív szükössége. A WHO és a UNICEF közös jelentése szerint jelenleg 748 millió fö, vagyis kilenc ember közül egy nem fér hozzá megfelelő minőségü, biztonságosan fogyasztható ivóvízkészletekhez. A problémát tovább súlyosbítja, hogy ezek az emberek általában a társadalmak marginalizált, elszegényedett rétegeihez tartoznak. Emellett 2,5 milliárd fó él a vízhozzáférés szempontjából nem megfelelő közegészségügyi körülmények között (WHO-UNICEF [2014], p. 8). A nem megfelelő minőségü ivóvíz használata és a higiéniai hiányosságok miatt kialakuló diarrhoea és szövődményei miatt naponta kb. 2300 fö veszti életét világszerte (Annette Prüs-Üstün et al. [2014], pp. 894-895).

Az ENSZ becslései szerint a vízfogyasztás aránya 2025-re a fejlett országokban 18\%-kal, míg a fejlődő országokban 50\%-kal növekszik majd. Ekkorra 1,8 milliárd ember él majd abszolútnak tekinthető vízszükösségben, ami azt jelenti, hogy alapvető szükségleteik kielégítése is akadályba ütközik a vízhiány következtében, míg a világ népességének kétharmada kerülhet jelentős nyomás alá a vízkészletekhez való hozzáférést illetően (UN-Water [2013b]). A több nemzetközi nagyvállalat által létrehozott 2030 Water Resources Group szerint 2030-ra a globális vízszükségletek 40\%-kal haladják majd meg a rendelkezésre álló forrásokat (2030 Water Resources Group [2009], p. 41).

A vízzel kapcsolatos válságok tehát súlyos problémákat okozhatnak a XXI. században, amik jelentősen befolyásolhatják a nemzetközi kapcsolatok alakulását is. Azt is szem előtt kell azonban tartani, hogy alapvetően nem arról van szó, hogy Földünk vízkészletei ne lennének elegendőek a népesség ellátására, hanem arról, hogy ennek elérése érdekében igen jelentős lépéseket kell tenni a vízfelhasználás, a vízigazgatás és a vízmegosztás terén világszerte. Mindezek eléréséhez nélkülözhetetlen a hosszú távú globális, regionális, nemzeti és helyi stratégiák kialakítása, ami a döntéshozók együttmüködése nélkül nem valósulhat meg. A döntéshozók világképét és döntéseit azonban jelentősen befolyásolhatja a tudományos szféra, a hidropolitikai elméletek így 
közvetlenül is hozzájárulhatnak a vízügyi kérdésekkel kapcsolatos kihívások kezeléséhez.

\subsection{A hidropolitika elméleti fejlődése}

A hidropolitika azonban hagyományosan empirikus irányultságú tudományág, ami azzal jár együtt, hogy napjainkig számos részletes esettanulmány készült már a határon átnyúló vízfelületekről és a vízmegosztás gyakorlati példáiról, az elméleti kutatások száma azonban igen kevés. Ennek fö oka az, hogy a hidropolitika úttöröi kezdetben nem a politikatudomány vagy a nemzetközi kapcsolatok müvelői közül kerültek ki, hanem földrajztudósok, mezőgazdasági szakértők, mérnökök vagy jogászok voltak, akik nem foglalkoztak a nemzetközi kapcsolatok elméleteivel (Warner-Zeitoun [2008], p. 802). Emellett azonban a politikatudomány és társadalomtudomány területeiről érkező hidropolitikai szakértők sem fektettek kellő hangsúlyt az elméleti megalapozottság fontosságára. A legismertebb szerzők, mint Peter H. Gleick, Thomas F. Homer-Dixon, vagy Tony Allan, nem járultak hozzá közvetlenül az elméletek fejlődéséhez, illetve nem kapcsolták kutatásaikat explicit módon a létező elméleti keretek egyikéhez sem (du Plessis [2000], p. 10). Azt is ki kell azonban emelni, hogy az explicit elméleti hozzájárulás hiánya nem jelenti azt, hogy a nemzetközi kapcsolatok elméletei teljesen ki lennének zárva az empirikus irányultságú hidropolitikai elemzésekből. Ehelyett inkább az a jellemző, hogy ezek „rejtve”, vagyis a szöveg egészéből kikövetkeztethetően, implicit módon jelennek meg, különösen a konfliktus és az együttmüködés megközelítéseivel kapcsolatosan (Furlong [2006], p. 439).

Mindezek következtében összességében elmondható, hogy a határon átnyúló vízfelületekkel kapcsolatos konfliktus és együttmüködés szakirodalmában csak igen ritkán találkozhatunk elméleti jellegü írásokkal - bár az is elmondható, hogy a közelmúltban egyre inkább megfigyelhetővé válik egy fordulat ebben a tendenciában (Furlong [2006]). A létező elméleti hozzájárulások nagy része azonban tipikusan a mainstream irányzatok, vagyis a neorealizmus és a neoliberalizmus alapvetéseit követik, az alapvetően kevés elméleti munka között csak elvétve találkozhatunk kritikai jellegü elemzésekkel (Warner-Zeitoun [2008], p. 803). A napjainkban megfigyelhető fordulatról azonban elmondható, hogy ez utóbbi írások száma és aránya növekedni látszik.

A hidropolitika elméleti fejlődésével kapcsolatban általában véve azonban jelenleg is igaz az az állítás, hogy a nemzetközi kapcsolatok elméleti háttere alapvetően 
alacsony szinten és egyoldalúan jelenik meg a vízügyi konfliktusok és együttmüködések vizsgálata terén. Az ehhez való hozzájárulás tehát viszonylag tág teret ad az érdeklődő kutatók számára, különösen a kritikai irányzatokat tekintve. Mivel értekezésem a konstruktivista keret alkalmazása mellett érvel, és egyik alhipotézise, hogy a vízmegosztással összefüggő államközi kapcsolatok változatosságát a materialista és statikus irányultságú racionalista elméletek, mint a neorealizmus és a neoliberalizmus, nem képesek mélyrehatóan vizsgálni, a következőkben a mainstream elméleteket és hiányosságaikat mutatom be, illetve, a konstruktivizmust Emanuel Adler nyomán „,middle-ground” elméletnek tekintve (Adler [1997]), a kritikai spektrum posztstrukturalista elméleteinek felhasználhatóságáról is ejtek néhány szót.

\subsection{A hagyományos racionalista elméletek hidropolitikai megközelítései}

\subsubsection{A neorealista neo-malthusiánus megközelités ${ }^{9}$}

A vízmegosztási kérdések államközi kapcsolatokra gyakorolt hatásának elemzése kapcsán két fő hidropolitikai elméleti irányzat alakult ki, a nemzetközi kapcsolatok diszciplína nagy iskoláinak megfelelően: a neorealista vagy neomalthusiánus, és a neoliberális vagy bőségszaru-megközelítés.

A neo-malthusiánus megközelítés (ld. Gleick [1993], [2010], Homer-Dixon [1994], [1999], Myers [1993], Soffer [1999]) nevét Thomas Malthus brit szerző után kapta, aki 1798-as Essay on the Principle of Population c. munkájában elsőként fogalmazta meg azt a tételt, hogy az erőforrások szúkössége, különösen, ha azt a népességnövekedés egyre meghatározóbbá teszi, éhínséghez, illetve háborúhoz vezethet. Malthus XXI. századi követői általánosságban véve olyan konfliktusokkal foglalkoznak, melyek a véges erőforrások növekvő kereslete és (a túlhasználat, a demográfia, vagy a környezeti tényezők miatt) szükülő kínálata között egyre növekvő különbség miatt alakulhatnak ki (Kipping [2009], p. 712).

A neo-malthusiánus elmélet hidropolitikai vonatkozásai arra az alapfeltevésre épülnek, miszerint az erőforrások, így a víz is, szükös javaknak tekinthetőek, melyek készletei a népesség növekedésével és a környezet változásaival egyre inkább korlátozottá válnak. Mindez pedig, Malthus eredeti elméletéhez hasonló módon, katasztrófához vezet majd (Malthus [1798/1998]). Thomas Naff szerint a víz

\footnotetext{
${ }^{9}$ A fejezet anyaga kis változtatásokkal publikálásra került a következő formában: Szálkai Kinga [2015]: „Nemzetközi vízügyek - konfliktus vagy együttmüködés? (1).” AJRC Elemzések, URL jelenleg nem elérhetö.
} 
„szükösséget okozó körülmények között egy magas szimbolikus értékkel rendelkező, könnyen eszkalálódó problémákat okozó, intenzív megnyilatkozásokat kiváltó, politikailag nagy mozgósító erejü, zéróösszegü játszmákat eredményező, hatalmi és presztízskérdésekkel terhelt erőforrássá válik, mely nagy valószínűséggel konfliktust eredményez, a kiváltott problémák megoldása pedig különösen nehéz” (Naff [1994], p. 274).

A vízkészletek végessége pedig nemcsak a vízhiányból fakadó közvetlen biztonsági fenyegetésekkel jár együtt, hanem a nemzetközi vízfelületek birtoklásából fakadó kötöttségek és függőségek formájában nagyfokú sebezhetőséget is jelent az államok számára. A víz mint stratégiai erőforrás biztonsága nélkülözhetetlen az állam müködéséhez és túléléséhez, ezért elméletben abszolút és kizárólagos szuverenitás lenne kívánatos felette. A nemzetközi vízfelületek esetében azonban nem nyílik lehetőség ilyen jellegü szuverenitás gyakorlására, ezért a vízbiztonságért és a vízellátás biztosításáért az államoknak kapcsolatba kell lépniük egymással. A neo-malthusiánus megközelítés szerint ez a szituáció folyamatosan feszültséget generál, és egyoldalú, konfliktust generáló állami lépésekhez vezethet az adott ország müködéséhez szükséges vízkészletek biztosítása érdekében. Az elmélet ezért kimondja, hogy a vízmegosztásban részes államok között nagy a konfliktus kialakulásának lehetősége.

A vízügyi kérdések biztonságpolitikai összefüggéseiről alkotott nézetek egyik radikális végpontját a vízháború-elméletek képezik. Ezek szerint a vízszűkösség előbbutóbb háborúhoz vezet majd, melyeket a megfelelő mennyiségü és minőségü vízkészletek biztosítására képtelen, vízbiztonságukat veszélyben érző államok robbanthatnak ki.

A vízháborús elméletek a hidegháború végét követően, a hagyományos bipoláris szembenállást felváltó sokdimenziós kihívások időszakában, az 'új típusú biztonsági kihívások’ fogalmának megjelenésével egyre népszerübbek lettek (Schmeier [2010], p. 5), napjainkban pedig a klímaváltozás hatásainak egyre érezhetőbbé válásával további megerősítést kapnak - legalábbis az ezen álláspont mellett elkötelezett szakértők szerint. A vízháborúk kitörésének alapja a neo-malthusiánus megközelítés szerint az, hogy az államok zéróösszegü játékként tekintenek a vízmegosztás kérdésére, és önérdekkövetésüket, túlélésért folytatott harcukat a vízért folytatott küzdelem keretei között folytatják le - akár katonai eszközökkel is. Peter H. Gleick ezt azzal támasztja alá és egészíti ki, hogy a vízkészletek „,a gazdasági vagy politikai hatalom forrásainak tekinthetőek. Ilyen körülmények között a vízhez való hozzáférés megfelelő indokot szolgáltathat egy háború kirobbantására, a vízkészletek pedig a háborús hódítás 
célterületeit képezhetik" (Gleick [1993], p. 84). Az elmélet ezért feltételezi, hogy a megnövekvő vízszükösség következtében a XXI. század konfliktusai, akár alacsonyabb, akár magasabb szinten, a vízmegosztás kérdéseire lesznek visszavezethetőek (Schmeier [2010]).

A vízháborúk, illetve a szélesebb értelemben vett vízügyi konfliktusok kialakulásának leggyakrabban idézett esettanulmányai a Közel-Kelet, föként Izrael és szomszédai érdekellentéteiből kerülnek ki. Joyce R. Starr már 1991-ben úgy vélekedett, hogy a Közel-Keleten ,a vízbiztonság hamarosan egyenrangúvá válik a katonai biztonsággal a védelmi miniszterek irodáiban" (Starr [1991], p. 19). Kevésbé elméleti jellegü forrásokban, zsurnalisztikai forrásokban gyakran előfordul, hogy párhuzamba állítják a vízkészletek és a szénhidrogének szükösségét, amellett érvelve, hogy „a víz az új olaj”, és ahhoz hasonlóan fegyveres konfliktusok robbannak majd ki birtoklásáért a közeljövőben (Zabarenko [2009]).

A vízügyi konfliktus kiváltó okainak tekintetében megoszlanak a vélemények. Gleick 1993-ban indikátorokat is meghatározott annak mérésére, hogy milyen vízügyekkel kapcsolatos körülmények növelik meg az államközi konfliktusok lehetségességét. Ide sorolta a szükösség mértékét, a megosztott vízkészletek kiterjedését, a vízmegosztásban részt vevő államok relatív hatalmának különbségeit, illetve az alternatív vízforrásokhoz való hozzáférési lehetőségeket (Gleick [1993], pp. 84-85). Gleick számos konkrét célt is megjelöl, amiért vízügyi konfliktus alakulhat ki. Ilyen cél lehet egyszerüen más államok vízkészleteinek vagy azok egy részének tényleges birtokba vétele, illetve az azok feletti kontroll megszerzése, de a vízkészletek egyenlőtlen elosztásának módosítása vagy más területeken való kompenzálása is. Gyakran az adott állam fejlődésének vízkészletek révén való korlátozása is felmerül, mint feszültségeket generáló tényező, nemcsak a vízmennyiség, hanem a vízminőség biztosítása terén is. Gleick szerint a vízkészletek nemcsak céljai, kiváltó okai lehetnek a konfliktusoknak, hanem eszközei is, például zsarolás révén, vagy egy már kirobbant háború menetében (Gleick [1993], pp. 86-89).

Miriam Lowi és Jay Rothman [1993] véleménye szerint a vízügyi konfliktusok szorosan egybefonódnak az adott államok között kialakuló más feszültségkeltő tényezőkkel, főként a high politics terén, vagyis az államiságot, az állambiztonságot vagy az államterületet érintő kérdésekben. Emiatt a vízügyi feszültségek feloldása csak akkor elképzelhető, ha ezeken a területeken is megvalósul ezek csökkenése (Schmeier [2010], p. 6). 
A vízháborúk bekövetkezését elörejelző szélsőséges neo-malthusiánus álláspontok mellett mérsékeltebb nézetek is jelen vannak, melyek szerint a vízszűkösség önmagában nem vezet közvetlenül konfliktushoz az államok között. Lowi és Rothman megközelítésének tükörképe például Thomas Homer-Dixon véleménye, miszerint a vízszükösség olyan esetekben válik nagy eséllyel konfliktus kiváltójává, amikor más tényezők hatására már kialakultak feszültségek, a rendezetlen vízügyi kérdések pedig hozzájárulnak ezek eszkalációjához (Homer-Dixon [1994], p. 19). Homer-Dixon a vízháborúkkal kapcsolatban meglehetősen szkeptikus, igen specifikus tényezőkhöz köti kialakulásukat. Environment, Scarcity and Violence [1999] c. könyvében például az olyan alvízi hegemón jelentőségét emeli ki egy vízügyi konfliktus kirobbantásában, amely számára a vízkészletek biztosítása kiemelt fontosságú, illetve megfelelő lehetőségekkel és politikai akarattal rendelkezik erőszak alkalmazására.

A legkevésbé szélsőséges, valamelyest neo-malthusiánusnak, de mindenképpen neorealistának tekinthető megközelítés a vízügyi hegemónia továbbfejlesztett elmélete, amelyben a hegemón stabilitás gondolatából kiindulva már nem is feltétlenül egyértelmü a konfliktus kialakulása a vízkészletek megosztásában részt vevő államok között. Mark Zeitoun és Jeroen F. Warner úgy véli, hogy azon esetekben, amikor egy hegemón emelkedik ki a parti államok közül, az képes arra, hogy saját akaratát érvényesítse a vízkészletek tekintetében, legyen szó konfliktusos vagy kooperatív elgondolásról, így mindkét lehetőség egyaránt megvalósulhat (Zeitoun-Warner [2000], p. 455). Homer-Dixon álláspontjával ellentétben tehát ezen elméleti keret szerint a hegemón viselkedését nem determinálja vízügyi helyzete, hanem megválaszthatja az általa legracionálisabbnak talált álláspont képviseletének formáját a vízmegosztás kérdésében, ezzel meghatározva a többi parti állam hozzáállását is.

A vízszükösség, mint potenciálisan konfliktust kiváltó tényező, nemcsak a nemzetközi kapcsolatok szakértői, hanem a nemzetközi rendszer döntéshozói érdeklődésére is számot tart. Ezek a megnyilatkozások sokszor a radikálisabb elméleti álláspontokkal függenek össze. Ezt mutatja például az a tény, hogy három egymást követő ENSZ-fötitkár hangsúlyozta, hogy egyre jelentősebbé válik a vízháborúk kitörésének valószínüsége. Butrosz Butrosz-Gáli már 1985-ben úgy nyilatkozott, hogy „a következö közel-keleti háború a víz, és nem a politika miatt fog kirobbanni,” míg Kofi Annan széles körben elterjedt kijelentése, miszerint „az édesvíz-készletekért folyó kiélezett verseny a jövőben konfliktusok és háborúk forrása lehet," 2001-ben hangzott el. A jelenlegi fötitkár, Ban Ki Mun 2007-ben nyilatkozta, hogy „,a következmények súlyosak az emberiség számára. A vízszűkösség fenyegeti mindazt, amit gazdaságilag 
és társadalmilag elértünk, és potenciálisan szítja a háborúk és konfliktusok veszélyét" (UNU [2011]).

$\mathrm{Az}$ eddig tárgyalt neo-malthusiánus megközelítések az államközi konfliktusokkal foglalkoztak a vízkészletek szükösségével összefüggésben. Egy további állásfoglalás szerint azonban ebben az összefüggésben sokkal inkább az államon belüli feszültségekre kell fókuszálni. Annak ellenére, hogy az ilyen jellegü konfliktusok helyi szinten zajlanak, elmondható, hogy fenyegetést jelenthetnek a nemzetközi békére és biztonságra, hiszen növelik az érintett állam instabilitását, illetve regionális következményekkel is járhatnak (Carius et al. [2004], p. 1).

A fentiek alapján összességében elmondható, hogy a neo-malthusiánus megközelítések közül azok rendelkeznek leginkább tudományos értékkel, melyek igyekeznek elkerülni a végletes leegyszerüsítéseket, túlzásokat, illetve nem tételeznek fel közvetlen, determinisztikus kapcsolatot a vízkészletek szükössége és a konfliktusok kirobbanása között. A történelem azt mutatja, hogy a vízügyi feszültségek és konfliktusok nagy része államokon belül alakul ki. Ha mégis államközi kérdésről van szó, akkor pedig az a legjellemzőbb, hogy a vízkészletek kérdése közvetett módon, egy (vagy több) már fennálló problémához kapcsolódva, azt tovább súlyosbítva, vagy az államok közötti bizalmatlanság növelésével vezethet valóban feszültségekhez, konfliktushoz. A vízháborúk elmélete napjainkban már szinte csak a zsurnalisztika és a populáris geopolitika tárgyaként, vagy politikai nyilatkozatok szintjén jelenik meg, a nemzetközi kapcsolatok elméletén belül elvesztette jelentőségét. Az 1990-es évek végétől a neo-malthusiánus indíttatású vízügyi konfliktusok „elkerülhetetlen stratégiai realitása” (Naff [1994], p. 274) is egyre inkább megkérdőjeleződik, az elemzések középpontjában leggyakrabban a vízkészletek körüli együttmüködés és annak megvalósítási lehetőségei állnak.

\subsubsection{A neoliberális böségszaru-megközelités ${ }^{10}$}

„Világunk vízproblémái azonban nemcsak feszültségek okozói lehetnek, hanem az együttmüködés katalizátorai is (...) ha közösen dolgozunk ezért, egy biztonságos és fenntartható jövőben lehet részünk” (Delli Priscoli-Wolf [2009], p. 9) - jelentette ki Kofi Annan ENSZ-főtitkár alig egy évvel a vízháborúkról tett, sokat idézett kijelentése után. A vízügyi konfliktusok elméletei kapcsán a kritikusok szóvá tették, hogy ezek

\footnotetext{
${ }^{10}$ A fejezet anyaga kis változtatásokkal publikálásra került a következő formában: Szálkai Kinga [2015]: „Nemzetközi vízügyek - konfliktus vagy együttmüködés? (2).” AJRC Elemzések, URL jelenleg nem elérhető.
} 
nem tesznek különbséget a vízügyi viták, konfliktusok, feszültségek és vízháborúk között, ami megtévesztő módon támaszthatja alá érvelésüket. Másrészt a körülmények változatosságának figyelmen kívül hagyása is hasonló hatásokat eredményez: a népességszám, az éghajlat, a vízhozzáférés, az érintett népesség kereskedelmi viszonyai és technológiai fejlettségi szintje nem elhanyagolható tényezők a vízszűkösség értékelésénél. A vízügyi konfliktusok veszélyének bizonyítására emellett egyértelműen a szélsőséges feszültségeket tükröző esettanulmányok bemutatását használták fel, melyekből nem lehetséges valóban releváns általános következtetések levonása (Wolf et. al. [2003], p. 31).

A neorealista neo-malthusiánus megközelítés kritikái közül a legjelentősebbeket tömörítő neoliberális bőségszaru-megközelítések nem tagadják teljességében az elképzelést, hogy a vízmegosztás kényszeréből fakadó politikai, gazdasági, környezeti és földrajzi interdependenciák konfliktushoz is vezethetnek az érintett államok között. A nemzetközi vízfelületek birtoklásából származó kötöttségeket és függőségeket azonban éppen ellenkezően értékelik, mint a konfliktusok kialakulása mellett érvelő elméletek, fö külpolitikára gyakorolt hatásukat abban látva, hogy az egymásra utaltság rákényszeríti az érintett államokat az együttmüködésre.

Az elmélet feltételezi tehát, hogy az együttmüködésből nyerhető relatív hasznok összessége meghaladja a konfliktusos úton elérhető hasznok összességét. Egy fegyveres összecsapásban a győzelem valószínüsége gyakran nehezen megjósolható, a rövid- és hosszú távú költségek, a keletkezett közvetlen anyagi, gazdasági és politikai károk pedig egyaránt sújtják a győztest és a vesztest. Az államoknak ezért egyszerü költséghatékonysági szempontból is érdemesebb elkerülni a konfliktust, nemcsak közvetlenül a vízháborúk tekintetében, hanem a feszültségek eszkalálódása terén is. Az elmélet követői úgy vélik tehát, hogy mindezek miatt sokkal nagyobb a valószínüsége annak, hogy az interdependenciák az együttmüködés felé mutatnak, a közös problémák közös megoldások keresésére ösztönzik az érintett államokat.

A megközelítést a történelem igazolja (ld. még Schmeier [2010]): a vízmegosztás kérdései az Aaron T. Wolf által szerkesztett Nemzetközi édesvízi viták adatbázisa (Transboundary Freshwater Dispute Database) szerint az elmúlt évezredek során jelentősen több alkalommal vezettek együttmüködéshez, mint konfliktushoz. Wolf munkássága azt is bizonyítani igyekszik, hogy a XX. században bekövetkezett, vízszűkösséget növelő változások nem növelték a vízháborúk számát. A szerző és munkatársai az elmúlt 50 évet tekintve arra a következtetésre jutott, hogy a vizsgált 1831 vízügyekkel kapcsolatos nemzetközi esemény kétharmada együttműködést tükröz, 
az államok csak ebben a periódusban 157 vízügyekkel kapcsolatos egyezményt kötöttek. Ugyanebben az időszakban csak 37 olyan alkalom volt, mikor az államok közötti vízkonfliktus túllépte a retorika szintjét, és valós ellenséges tevékenységekben (gátak felrobbantása, fegyverhasználat, katonai lépések) jelent meg (Postel-Wolf [2009]). Wolf és szerzőtársai felhívják a figyelmet arra is, hogy az utolsó valódi vízháború, melyben két állam között elsődlegesen a vízkészletek birtoklása miatt alakult ki konfliktus, 4500 éve történt, Umma és Lagas között Mezopotámiában, miközben Kr. e. 805. és 1984 között több mint 3600 vízügyekkel kapcsolatos egyezmény köttetett (Wolf et. al. [2003], p. 30).

A vízbiztonsági kérdések kezelésére a gyakorlatban az elmélet szerint gyakran nemzetközi rezsimek jönnek létre, melyek közvetítő szerepük révén csökkentik a konfliktus lehetőségét, és az információáramlás javításával megnövelik az együttmüködési potenciált az érintett államok között. Helga Haftendorn [2000] szerint akkor beszélhetünk vízügyi rezsimekről, amikor a részes államok a feszültségek kialakulásakor vagy megnövekedése esetén figyelembe vesznek egy nemzetközileg létrehozott szabályrendszert, ami a vízügyi konfliktusok kezelésére jött létre. Ilyen szabályrendszer több célra is létrejöhet, mint például a vízmegosztás rendezése, a szennyezés megakadályozása, a vízkészletekhez kapcsolódó költségek megosztása, illetve ezek folyamatos megfigyelése és érvényesítése. Haftendorn szerint mindenképpen különbséget kell tenni azon rezsimek között, melyek általánosan a vízkonfliktusok rendezésére jöttek létre, illetve melyek egy adott konfliktusra vonatkozó szabályozásokon alapulnak.

Az általános vízügyi rezsimekre jó példa a határokat átlépő vízfolyások és nemzetközi tavak védelmére és használatára vonatkozó, Helsinkiben, 1992. március 17én aláírt ENSZ Egyezmény, mely 1996-ban lépett hatályba, illetve a nemzetközi vízfolyások nem-hajózási célú használatáról szóló 1997. évi ENSZ Egyezmény, mely 2014-ben lépett hatályba. Mindkét egyezmény általános érvényű szabályozásokat hozott létre, melyek a világ bármely pontján kialakuló vízügyi konfliktus rendezéséhez megfelelő iránymutatást biztosíthatnak többek között az egyenlő és igazságos vízfelhasználás, vagy a károkozás elkerülésének elve által (Haftendorn [2000], pp. 6566).

Az ilyen és ehhez hasonló dokumentumok azonban nem mindig alkalmasak arra, hogy egy adott eset jellegzetes körülményei között valós megoldást kínáljanak, különösen, ha nem kötelező érvényü rendelkezésekről van szó. Ezt a célt szolgálja a specifikus rezsimek létrehozása, melyek a legtöbb esetben vegyes bizottságok 
kialakítását jelenti a vitás felek között, annak érdekében, hogy meggyorsítsák az információcserét, tudományos és technikai kutatást végezzenek és ennek segítségével kivitelezhető megoldási lehetőségeket vázoljanak fel minden fél számára elfogadható megállapodások keretei között. A történeti tapasztalatok azt mutatják, hogy a legspecifikusabb rezsimek és megállapodások a leginkább sikeresek az együttműködések kialakításában és megerősítésében (Haftendorn [2000], p. 66).

Wolf kutatásai azt is bizonyítják, hogy ha az érintett államok között egyszer sikeresen létrejön egy komplex vízigazgatási rezsim, az általában hosszú ideig képes fennmaradni és biztosítani a feszültségek csökkentését, még olyan esetekben is, amikor az adott államok között más kérdésekben konfliktus alakul ki (Wolf [1998], p. 260).

Más szerzők az emberi kreativitásban, azon belül is a technológiai újításokban látják a békés megoldás és az együttműködés lehetőségét a vízmegosztásban érintett államok között. Ezek egy része a szűkösség csökkentésére irányul, különböző módokon megnövelve a rendelkezésre álló vízkészleteket, míg más részük a vízigazgatás körülményeinek javításával kívánja elérni a meglévő vízkészletek hatékonyabb felhasználását. Mindkét megközelítés osztja azt az álláspontot, hogy a technológiai újítások minél hatékonyabb megvalósításához elengedhetetlen az államok közötti együttmüködés - mely nagy valószínüséggel más területeken is előmozdítja az államközi kapcsolatok fejlődését.

Az alternatív vízkészletek létrehozásának több módja is lehetséges. Ezek egyike az újrahasznosítás, mely általában víztisztítás és az esővíz vagy az ún. szürke vízkészletek (háztartási célokra, mosásra, kézmosásra használt víz) újrafelhasználása útján történik. Ez a megoldás közvetlenül a közösségek szintjén is érvényesíthető, legyen az egy folyóhoz kapcsolódó, transznacionális mikrorégió, vagy egy adott állam szükösségtől leginkább érintett területei (OECD [2007/2008]). A technológiai újítások révén elérhető vízkészlet-bővítés másik fő eszköze a tengervíz sótalanítása, ami azonban egy rendkívül költséges folyamat, és egyértelműen kormányzati vagy transznacionális szinten valósulhat meg. Izrael és Jordánia például 2015-ben aláírta a Vörös-tenger-Holt-tenger megállapodást, mely szerint a Holt-tenger megfelelő vízszintjének biztosítására csatorna épül a két állam között, mely mellett Akabában sótalanító létesítmény is épül majd. A létesítmény által kitermelt édesvizet a két állam megosztja egymás között, ezzel csökkentve a vízszűkösséget a régióban (al-Khalidi [2015]).

A vízigazgatás körülményeinek javítása terén a legelterjedtebb koncepció az IWRM (Integrated Water Resource Management), vagyis az integrált vízigazgatás. Az 
IWRM központi gondolata a már említett kölcsönös függőség rendszere, de ebben az esetben nem államok, hanem különböző szektorok között, mint a társadalom, a gazdaság és a természet. Az IWRM keretei között egy koordinált fejlesztési tevékenység zajlik, ami nemcsak a vízkészleteket és azok felhasználását veszi figyelembe, hanem az ezekhez kapcsolódó erőforrásokat és tevékenységeket is, mint például a mezőgazdaság és az ipar lehetőségeit, annak érdekében, hogy biztosítsa a gazdasági és társadalmi jólét növekedését a fenntartható fejlődés keretein belül (GWP [2010], Allan [2003b]). Egy nemzetközi vízfelület esetében mindezen tevékenységek államközi együttmüködés révén valósulhatnak meg, az IWRM tehát szintén a vízügyi kérdések békés rendezését segíti elő.

A vízügyi együttmüködés szempontjából szintén fontos fogalom a „virtuális víz”, ami már nem a technológiai megoldásokhoz kapcsolódik, hanem a világgazdaság részeiként kialakult globális és regionális kereskedelmi rendszerekhez. A megközelítés egyik legjelentősebb követője és létrehozója, Tony Allan véleménye szerint a vízszükösség nem jelenthet komoly biztonsági kihívást az alkalmazkodni kész politikaigazdasági szereplök számára, ezek ugyanis könnyen elérhetik a globális kereskedelmi rendszerben felhalmozódott víztöbbletet (Allan [2002], p. 1). Globális szinten ugyanis megfelelő mennyiségű víz áll rendelkezésre ahhoz, hogy a vízszükében lévő államok által igényelt vízigényes javak előállítása megvalósulhasson. Ezen javaknak ugyanis saját „beágyazott” virtuális víztartalma van, ami megfeleltethető az előállításánál felhasznált vízmennyiségnek. Kereskedelmi forgalmuk révén egy, a vízszükösségtől fokozottan sújtott állam képes arra, hogy pótolja, helyettesítse, virtuálisan elérje a számára szükséges vízkészleteket. Allan példája szerint egy tonna gabona előállításához 1000 köbméternyi vízre van szükség. Ha egy vízszúkében lévő állam ezt a gabonamennyiséget megvásárolja, megtakarítja mindazt a gazdasági erőforrást és társadalmi feszültséget, ami ennek megtermeléséhez szükséges lett volna. A KözelKelet és Észak-Afrika térsége 2000 körül évente 50 millió tonna gabonát importált. Ha ezt a régió saját erejéből állította volna elő, $50 \mathrm{~km}^{3}$-nyi vízre lett volna szükség - ami megfelel a Nílus szükösebb időszakokban tapasztalt éves vízhozamának Egyiptomban (Allan [2003a], p. 5). Mindezek alapján levonható tehát a következtetés, hogy a vízigényes áruk globális és regionális forgalma nagymértékben hozzájárul a vízkészletek körüli együttmüködés és békés viszonyok kialakításához és fenntartásához.

Az államok közötti vízügyi együttmüködésnek tehát számos dimenziója létezik: a nemzetközi interdependenciákra épülő vízügyi rezsimek létrehozása, a technológiai újítások és a nemzetközi kereskedelem szerepét előtérbe helyező megközelítések 
egyaránt jó példákat szolgáltatnak arra, hogy a vízkészletek szükössége nem feltétlenül vezet konfliktushoz a nemzetközi rendszerben, megosztásuk kényszere pedig egyértelműen hozzájárul a közös megoldások kereséséhez, a valós kooperáció kialakulásához - ami a spill-over hatás következtében más területeken is elösegítheti az államok közötti együttmüködést.

Mindezen kérdések vizsgálata azonban számos jelenségre nem ad választ. A vízügyi kérdések a történelem során számos esetben hozzájárultak háborús helyzetek, feszültségek, fegyveres összecsapások kirobbanásához vagy eszkalálódásához. Tény, hogy a vízmegosztásban érintett államok körében elterjedt a potenciális vízügyi konfliktus megelőzésére való törekvés, ami a fenyegetettség érzékelését mutatja. A szerződéses, intézményesült együttműködések igen kevés esetben működnek teljes mértékben kielégítő módon (ezen ritka esetek általában a fejlett világ államai között jöttek létre), különösen a vitarendezési mechanizmusok és a kikényszeríthetőség területein (Julien [2012], p. 55). A vízháborúk hiánya pedig semmi esetre sem értelmezhető vízügyi együttmüködésként, vagy a feszültségek általános hiányaként.

A felsorolt példákból látható, hogy a bőségszaru-megközelítés esetében is igaz az, amit a neo-malthusiánus elméletek kapcsán már megállapítottunk: a közvetlen, determinisztikus kapcsolat feltételezése a vízkészletek szükössége és az együttmüködés kialakulása között gyakran félrevezető lehet a tudományos igényü vizsgálódások során, végletes leegyszerüsítéseket és túlzásokat eredményezve. Amint a fenti példák mutatják, a bőségszaru-megközelítés több szempontból meghaladja a neo-malthusiánus elméleti keret alkalmazhatóságát, például a számításba veendő aktorok körét, vagy a vízszükösség abszolút voltát árnyaló tényezők elemezhetőségét illetően, a neomalthusiánus elmélethez hasonlóan azonban ez a megközelítés sem ad választ arra, hogy miért figyelhető meg empirikusan a konfliktus és az együttműködés változó intenzitása ugyanazon kérdésekben.

\subsubsection{A racionalista elméletek kritikái}

A vízügyi kérdések neorealista neo-malthusiánus és a neoliberális bőségszarumegközelítéseinek áttekintése után azt az igen fontos következtetést vontam le, hogy egyik elméleti keret sem képes választ adni arra a kérdésre, hogy miért alakulhat ki ugyanazon területen, ugyanazon körülmények között egy adott időszakban együttmüködés, egy másik időszakban pedig konfliktus a vízkészletek megosztása kapcsán. Ennek megértéséhez szükséges visszanyúlni a két irányzat gyökereihez, és 
megvizsgálni, hogy a neorealizmus és a neoliberalizmus racionalista elméletei hogyan viszonyulnak a nemzetközi kapcsolatokban a változás kérdéséhez általánosságban véve, illetve milyen ontológiai, episztemológiai és módszertani elvek vezettek ezen álláspont kialakulásához.

A racionalista elméletekre általánosságban véve nem jellemző a hagyományos ontológiai és episztemológiai alapvetések megkérdőjelezése. Mind a neorealizmus, mind a neorealizmus abból indul ki, hogy a valóság objektíven létező, megtapasztalható, megismerhető és leírható, a nemzetközi kapcsolatok pedig általános törvényszerüségeknek engedelmeskednek, melyek a természeti törvényekhez hasonlóan müködnek (Adler [1997], p. 321). Mindkét elméletre jellemző a racionális döntéshozatal és az instrumentalizmus feltételezése, vagyis, hogy a nemzetközi rendszer szereplői (általában az államok) költség-haszon elemzések alapján érvényesíti érdekeiket, önérdekkövető, atomisztikus aktorokként jelennek meg (Reus-Smit [2005], p. 188), melyek identitása és érdekei adottak (Smith [1997], p. 184). Sem a neorealizmus, sem a neoliberalizmus nem tekint az ideák, a normák és az értékek szintjén megjelenő társadalmi világra a valóságot konstruálni képes erőként (bár mindkét racionalista irányzat modernebb változatai esetében megjelennek ezek a fogalmak, szerepük sokkal passzívabb és kevésbé jelentős) (Hurd [2008], pp. 301-302).

Episztemológiailag mindkét elmélet megismerhetőnek tartja a világot, méghozzá főként pozitivista eszközökkel, amiből az következik, hogy fő törekvésük az általános, objektíven megtapasztalható törvényszerüségek keresése (Selby [2003], p. 63), melyek az esetek nagy többségében megfelelő iránymutatást jelentenek. Mind a neorealizmus, mind a neoliberalizmus célként tüzi ki, hogy nagyelméletként egy átfogó, univerzális, időben és térben alapvetően állandónak tekinthető és általánosan alkalmazható keretet dolgozzanak ki a nemzetközi kapcsolatok jelenségeinek magyarázatára és elörejelzésére. Mindez magában hordozza annak a determinizmusnak a gyökereit, amivel a vízmegosztással összefüggő államközi kapcsolatok példáinak esetében találkoztunk.

A racionalista elméletek módszertanilag következetesen a pozitivizmus megközelítését alkalmazzák, vizsgálódásaik alapvetően kvantitatív természetűek. A pozitivista módszertan a természettudományok világából származik, és határozottan elválasztja az empirikusan tapasztalható és megfigyelhető tényeket az ideák világától, az előbbiek feltárására és összefüggéseinek vizsgálatára törekedve. Az objektívnek tekintett valóság elemeiben jelen lévő rendszer leírását tekinti fő feladatának, amit rendszeres és megismételhető empirikus megfigyelésekkel, kísérletekkel ér el. 
Christopher Lloyd az 1990-es évek elején négy fó tulajdonsággal jellemezte a nemzetközi kapcsolatok elméletében is alkalmazott pozitivista módszertant: 1) logika, vagyis a tudományos elméletek objektív bizonyításának meg kell felelnie a deduktív logika szabályrendszerének; 2) empirikus verifikálhatóság, vagyis, hogy csak a definíció szerint igaz, illetve az empirikusan verifikálható vagy falszifikálható állítások tekinthetők tudományos állításoknak; 3) az elmélet és a megfigyelés közötti különbségtétel, amelyben a megfigyelés elméletileg semlegesnek minősül; 4) az okság Hume-i követelménye, miszerint az oksági viszony fennállása időben változatlan kapcsolatot jelent a megfigyelt események között (Smith [1996], p. 17). Emellett az is elmondható, hogy a racionalista elméleti keretekkel szemben követelmény, hogy képesek legyenek a jövőbeli események elörejelzésére, és közvetlen módon megfelelő eligazítást adjanak a döntéshozók számára (Lamont [2015], p. 19). Mindez számottevő korlátokat jelent a racionalista elméletek számára, különösen a társadalmi törvényszerüségek természeti törvényszerüségektől való eltérései esetében, mint például az identitás, a normák, a kultúra vagy a nyelv vizsgálatában, a társadalmi változások dinamikája mögött álló folyamatok megértésében, vagy a hatalmi viszonyok leírásában.

$\mathrm{Az}$ általános racionalista alapvetések áttekintése után visszatérhetünk a vízmegosztással összefüggő államközi kapcsolatok változatosságának specifikus példájára. Ezek tekintetében mind a neo-malthusiánus, mind a bőségszaru-megközelítés feltételezi, hogy a nemzetközi vizek materiális jelenlétükből fakadóan közvetlen hatással bírnak az államközi kapcsolatok alakulására (Hurd [2008], p. 300). Ez a feltételezés azonban széleskörü kritikák tárgya - a szakirodalom és az empirikus megfigyelések ugyanis azt mutatják, hogy nem indokoltak azon állítások, melyek a vízmegosztással összefüggő államközi kapcsolatok kizárólagos konfliktusos vagy együttmüködéses volta mellett érvelnek (Oswald Spring-Brauch [2009], p. 189). A neorealista és neoliberális elméletek statikussága, vagyis a térbeli eltérések figyelmen kívül hagyása és az időbeli állandóság és változatlanság feltételezése is jellemző a hidropolitikai irányzatokra: mivel ezek időben és térben általános jelenségeket írnak le, nem képesek értelmezni, hogyan válhat lehetségessé az az empirikusan gyakran tapasztalt esemény, hogy egy hosszú időn át tartó együttmüködés konfliktusossá válik, vagy ennek fordítottja következik be.

Összességében tehát a fentebb áttekintett gyakorlati példák mellett a neorealizmus és a neoliberalizmus racionalista elméleteinek általános kritikája alapján is levonható a következtetés, hogy sem a neo-malthusiánus, sem a bőségszaru- 
megközelítés nem alkalmas a vízmegosztással összefüggő államközi kapcsolatok dinamikus változásainak vizsgálatára (Reus-Smit [2005], p. 206).

A gyakorlati példák és az elméleti kritikák elemzése révén tehát két oldalról is bizonyítottnak tekintem első alhipotézisemet, miszerint a vízmegosztással összefüggő államközi kapcsolatok változatosságát a materialista és statikus irányultságú racionalista elméletek (neorealizmus, neoliberalizmus) nem képesek mélyrehatóan vizsgálni. A következőkben második alhipotézisem bizonyításának elméleti alapjait fektetem le, vagyis azt elemzem, hogy a konstruktivizmus elméleti kerete milyen alapvetéseket és eszköztárat kínál a neorealizmus és a neoliberalizmus hiányosságainak kiküszöbölésére a vízmegosztással összefüggő államközi kapcsolatok változatosságának vizsgálatában.

\subsection{A konstruktivizmus alapvetései és hidropolitikai megközelítései}

A konstruktivizmus az 1980-as években jelent meg a nemzetközi kapcsolatok elméletében, alternatív irányzatként azonban csak az 1990-es években került előtérbe, a Szovjetunió békés felbomlásának magyarázata révén, melyet a hagyományos elméletek sem elörejelezni, sem magyarázni nem tudtak kielégítően. Emanuel Adler szerint napjainkban a konstruktivizmus már egyértelmüen a nemzetközi kapcsolatok mainstream elméleteinek egyikévé vált világszerte (Adler [2012], p. 118).

A konstruktivizmus részletesebb tárgyalása elött szükséges kiemelni azt a jellegzetességet, ami az irányzatot már első ránézésre elkülöníti a hagyományos elméletektől. A konstruktivizmus ugyanis nem tekinthető a liberalizmushoz vagy a realizmushoz hasonló, univerzális elméletnek. Vagyis nem törekszik arra, hogy átfogó, mindenre kiterjedő magyarázatot adjon a világ jelenségeire, vagy, hogy megkérdőjelezhetetlen törvényeket és objektív igazságokat tárjon fel a „megfelelő” szemszögből nézve, melyek az időbeli és térbeli különbségeke figyelmen kívül hagyva egyforma hatékonysággal alkalmazhatóak a nemzetközi kapcsolatokban. Emellett azt is fontos kiemelni, hogy a konstruktivizmus nem statikus létükben szemléli ezeket a jelenségeket, hanem inkább „valamivé válásuk folyamatában” (Adler [2012], p. 113). A konstruktivizmus tehát nem a társadalmi világ egyetemes elméletét jelenti, hanem egy tulajdonképpeni perspektívát ad annak értelmezéséhez és megértéséhez (KurowskaKratochwil [2012], pp. 86-89; Reus-Smit [2005], p. 202). Kiss J. László ezt a jelenséget 
úgy fogalmazta meg, hogy a konstruktivizmus „az elméletek elmélete”, vagy „a paradigmák paradigmája", melynek lényege az érzékelt valóság kialakulási folyamatainak megismerése és alakítása (Kiss J. [2009], pp. 355-356). Emanuel Adler eközben arra helyezi a hangsúlyt a konstruktivista elméletek kategorizációjánál, hogy ezek középutat (,middle ground”) képeznek a racionalista és az általa interpretívként kategorizált kritikai, posztmodern és posztstrukturalista elméletek között (Adler [1997], p. 319). Mindennek részletesebb bemutatásához érdemes az irányzatot az ontológia, az episztemológia és a módszertan dimenzióiban megvizsgálni.

Adler 1997-ben, a konstruktivizmus elméleti irányzattá válásának korszakában a következőképpen definiálta azt: „A konstruktivizmus az a nézet, miszerint az anyagi világ és az emberi cselekvés kölcsönhatásainak alakulása az anyagi világ dinamikus normatív és episztemológiai interpretációitól függ." (Adler [1997], p. 322). Ez a definíció jól tükrözi a konstruktivizmus ontológiai alapvetését, melyben az anyagi világ materialitása nem önmagában határozza meg az emberi cselekvést, és ezzel együtt (többek között) a nemzetközi kapcsolatok alakulását, hanem az ehhez interszubjekítv módon társított, relatíve állandónak tekinthető, de folyamatosan változni képes jelentéstartalmak révén. A valóság tehát nem objektíven és statikusan létező, amint a racionalista elméletek értelmezik, törvényei pedig nem a természeti törvényekhez hasonlóan müködnek, hanem alapvetően társadalmi jellegüek; nem fizikai, hanem társadalmi tények alapján épülnek fel.

Azt is hangsúlyozni kell azonban, hogy a konstruktivizmus nem veti el a materiális világ anyagi természetű elemeinek fontosságát és jelentőségét az emberi cselekvés és a nemzetközi kapcsolatok alakulása szempontjából, az interszubjektív jelentéstársítás folyamata nem valósulhatna meg azok nélkül a materiális elemek nélkül, melyekhez ezek a társadalmi kommunikációs folyamatok révén kapcsolódnak, létük és számításba vételük tehát szintén kulcsfontosságú az elemzések szempontjából (Adler [1997], p. 323). Steve Woolgar [1983] kategorizációja szerint a fent leírtak miatt konstruktivizmus ontológiailag „mediativistának”, közvetítő jellegűnek tekinthető a materiális világ és a társadalmi jelentések világa között, az irányzat szerint ezek kölcsönhatása hozza létre, konstruálja a társadalmi valóságot, vagyis az identitásokat, érdekeket és viselkedési formákat.

Episztemológiailag a konstruktivizmus lényege abban fogalmazható meg, hogy a tudás maga is társadalmilag konstruált (Kiss J. [2009], p. 355), tehát az interpretációk szerepe meghatározó a világ megismerésében. Az interpretációk folytonos általánosításokat hoznak létre a tudomány fő alkotóelemeiként, melyek nyitottak a 
változásokkal szemben. Érdemes kiemelni, hogy eszerint a jelentéstársítási folyamatok mindig kétszer mennek végbe, egyszer társadalmi valóságként, egyszer pedig az ezekről alkotott tudományos ismeretek kialakulása során. Az önreflexió is fontos szerepet játszik a tudományos életben: a tudósnak minden esetben arra kell törekednie, hogy tisztában legyen egyrészt a vizsgált elemek kontextusával és az abból származó implikációkkal, másrészt pedig saját pozíciójával. A kontextus megismerésének szerepe rendkívül jelentős, mivel a társadalmi tények csak az adott körülmények, identitások, értékek, érdekek, normák, szabályok, intézmények és diskurzusok alapján értelmezhetőek. A konstruktivista episztemológia szerint a világ megismerhetősége nagymértékben korlátozott, ami nagyrészt a társadalmi tények homályos és változékony természetéből fakad. Emellett azonban a konstruktivizmus nem tekinti relatívnak a tudományosságot; elfogadja, hogy bizonyos állítások nagyobb magyarázó erővel, illetve érvényességgel rendelkezhetnek, mint mások (Adler [2012], p. 113, 121-122).

A konstruktivisták fő célja, hogy különböző módszertani eszközök segítségével feltárják, leírják és megmagyarázzák, hogy hogyan jönnek létre az érzékelt valóságot alakító társadalmi konstrukciók. Ehhez változatos módszereket alkalmaznak (ld. a konvencionális konstruktivizmus leírásánál), a legjellemzőbb azonban az interpretív, poszt-pozitivista és kvalitatív eszköztár használata. Közös célnak tekinthető az interszubjektív módon megvalósult jelentéstársítások folyamatainak feltárása, amihez általában interpretív eszközök szükségesek, illetve a kontextus megismerése és megértése, ami a „sűrü leírások” módszere révén valósulhat meg.

A konfliktusok és együttmüködések jelentéstartalmainak vizsgálata a konstruktivizmus egyik legismertebb szerzőjének egyik leggyakrabban idézett példájában már 1995-ben az elmélet fontos részévé vált. Alexander Wendt szerint „55 brit nukleáris fegyver kevésbé veszélyes az Egyesült Államok számára, mint 5 északkoreai, mert a britek baráti kapcsolatot ápolnak az Egyesült Államokkal, az északkoreaiak pedig nem; a barátságosság és az ellenségesség fogalma pedig az egymásról alkotott elképzelések közösségén alapul” (Wendt [1995], p. 73). Ebből a rövid idézetből kiderül, hogy a materiális tartalmaknál nagyobb jelentőségü a társadalmilag társított jelentéstartalom, hogy a kontextus igen nagy szerepet játszik az események értékelésénél és a biztonságpercepciók kialakulásánál, illetve, hogy a barátságosság és az ellenségesség (jelen értekezés fogalomhasználatában az együttmüködés és a konfliktus) egyértelmüen társadalmi konstrukciók mentén jön létre, és ezek közösségén alapulva marad fenn. Wendt ugyanezt a példán túl is számos alkalommal hangsúlyozza, kimondva, hogy ,,az emberek annak megfelelően kezelik viselkedésük tárgyát, beleértve 
a többi embert is, amilyen jelentéssel ezek a tárgyak számukra bírnak” (Wendt [1999], p. 140). A konfliktus és az együttmüködés kialakulása a nemzetközi kapcsolatokban tehát Wendt szerint azokra a jelentéstartalmakra vezethető vissza, amik társadalmi konstrukciók, diskurzusok révén az adott államközi kérdésekhez társulnak. Mivel ezek folyamatos kölcsönhatásban állnak egymással, térben és időben is változónak tekinthetőek - ezáltal valósul meg Wendt korszakos múvének címe, miszerint a nemzetközi rendszerben „az anarchia az, amivé az államok teszik."11 Az államok érdekeit és külpolitikáit ugyanis identitásuk határozza meg, melyre nagy befolyással van a kulturális kontextus, illetve a gazdasági és társadalmi élet jellegzetességei is (Aras [2009], p. 30). A nemzetközi rendszerben uralkodó viszonyok, a konfliktus és együttmüködés rendszerei tehát nem tekinthetőek állandónak, az államok viselkedésének megváltozása egyértelműen hatással van ezekre. A konstruktivista kutatási napirend fő célja, hogy feltárja az ezen változások mögött húzódó okokat, visszavezetve azokat az érdekek, az identitások, a normák, a kultúra és a kontextus diskurzusformáló változásaira.

A konstruktivizmus általános áttekintésének lezárásaként érdemes kitérni a konstruktivizmus és a posztmodern/posztstrukturalista/kritikai irányzatok közötti alapvető hasonlóságokra és különbségekre is. Az utóbbiak általános jellemzője, hogy a világot ontológiailag teljes mértékben relatívnak tekintik, a konstruktivizmus materialista elemei hiányoznak ezen elméletekből. Mindennek révén a tudás természete és megszerezhetősége is relatív, az interpretációk fontossága pedig kiemelkedő. Ez utóbbit olyan értelemben viszik tovább a konstruktivizmusnál, hogy nem tekintik relevánsnak a materiális világ anyagi jellegü elemeinek és struktúráinak vizsgálatát, az ideák, a nyelv és az interpretációk vizsgálatát tekintik egyedül fontosnak és vizsgálódásra érdemesnek (Adler [1997], p. 321). Jeffrey C. Alexandert ([1995], p. 103) idézve elmondható, hogy a valóság ezen irányzatok számára ”nem lehet más, mint egy szöveg, egy szimbolikus konstrukció, ami más szövegekhez (nem a történelemhez, vagy társadalmi struktúrákhoz) kapcsolódik önkényes módon.” A relativitás a tudományosság értelmezésére is rányomja a bélyegét, a posztmodern/posztstrukturalista/kritikai irányzatok esetében számos egyenlő értékü alternatív magyarázattal találkozhatunk.

\footnotetext{
${ }^{11}$ Wendt fő művét számos kritika érte, melyek nagy része a szerző államközpontúságát emelte ki. Wendt ezzel ugyanis objektivizálja az államokat, és figyelmen kívül hagyja azok konstruált természetét (ld. Zehfuss [2006]). A szerző tisztában van ennek problematikusságával, érvelése szerint azonban a tudományosság, a parszimónia miatt nem találta indokoltnak meghaladni az államok elemzési keretét (Reus-Smit [2005], 199-200). Jelen disszertáció szerzője is ezt az álláspontot követi, de tisztában van az államközpontú konstruktivista elemzés inherens korlátaival. A következtetések között a kutatás további irányainak áttekintésénél emiatt az államközpontúság meghaladása is szerepet kap.
} 
Összefoglalásul tekintsük át a konstruktivizmus hozzáadott értékét a racionalista/materialista elméletekkel szemben. Az értekezés szempontjából leginkább jelentős hozzáadott érték a változás leírásának, elemzésének és magyarázatának képessége, mint erre a későbbiekben fény derül majd. A változás elemezhetőségének megvalósítása mellett fontos kiemelni azt az újdonságot, hogy az anyagi és a szellemi tényezőket a korábbiakkal ellentétben a konstruktivizmus együttesen, egy egységként értelmezi, melyek folyamatos kölcsönhatásban állnak egymással, tehát nem egymás alternatíváiként, hanem kiegészítőiként jelennek meg a valóság alakításában. Ennek révén arra is képessé válik, hogy a hagyományos elméletek által nem magyarázott alapfogalmak (mint például az érdek és az identitás) kialakulásáról, változásának dinamikájáról is képet adjanak. A konstruktivizmus továbbá olyan elemeket emelt be a nemzetközi kapcsolatok elemzésébe, melyek korábban nem voltak hangsúlyosan jelen, illetve csak marginális jelentőséggel bírtak. Ezek közül a legfontosabb a kulturális kontextus és a nyelv szerepe, melyek révén a megismerés új dimenziói válnak elérhetővé. Bár jelen értekezés nem foglalkozik mélyebben a jelentéstársításhoz kapcsolódó hatalmi viszonyok vizsgálatával, a konstruktivizmus ezen hozzáadott értékét is felhasználja a gyakorlatban, amikor domináns/hegemón diskurzusok elemzésével vizsgálja meg a közép-ázsiai vízbiztonság kérdését. A konstruktivisták által értelmezett valóság tehát összességében jóval széleskörübb értelmezéseknek és a változás magyarázata révén több lehetőségnek enged teret, mint a hagyományos racionalista elméletek világa.

Zárásként elmondható, hogy a konstruktivizmus valóban egy „middle-ground,” vagyis középutas elmélet, mely a materializmus és az idealizmus, az egyéni cselekvőképesség és a strukturális meghatározottság, a racionalizmus és a relativizmus között igyekszik hidat képezni. A középutasság mellett azonban a konstruktivizmuson belül is több ág alakult ki, annak megfelelően, hogy melyik irányba mozdulnak el ezek ontológiai, episztemológiai és módszertani jellegzetességei a racionalista és a posztmodern/posztstrukturalista/kritikai irányzatok között. A következő alfejezet az értekezésben alkalmazott konvencionális konstruktivizmus jellegzetességeit mutatja be az interpretív/kritikai konstruktivizmussal egybevetve.

\subsubsection{A konvencionális konstruktivizmus}

A racionalista elméletek és a konstruktivizmus jellegzetességeinek általános áttekintése során egyértelmű bizonyítást nyert, hogy az utóbbi számos hozzáadott 
értékkel bír az elöbbiekkel összevetve. Ez azonban nem jelenti azt, hogy a racionalista elméletek teljes egészükben elvetendőek lennének, akár általánosságban, akár a vízmegosztással összefüggő államközi kapcsolatok vizsgálatában. A konstruktivista szerzők egy része egyetért abban, hogy a racionalista elméletek bizonyos elemei nélkülözhetetlenek a tudományosság kritériumainak való megfelelés érdekében, és amellett érvelnek, hogy ezért valamilyen szinten szükséges a relativizálás, a normativitás és az önreflexió korlátok közé szorítása. A szerzők között azonban nincs egyetértés abban, hogy hol húzódik a határ ezekben a kérdésekben, a konstruktivizmus irányzatán belül emiatt egymástól nagyon eltérő felfogásokkal is találkozhatunk, melyek között jelen értekezés alapvetéseinek megértése szempontjából is szükséges különbséget tenni.

Munkámban ehhez Jeffrey T. Checkel és Ted Hopf elkülönítését alkalmazom a konstruktivizmus két fó ága, az interpretív/kritikai és konvencionális konstruktivizmus között. A két ág természetesen számos közös tulajdonsággal rendelkezik. Mindkettő a társadalmi világ konstrukcióinak feltárására törekszik, melyet az interszubjektív valóság és jelentéstartalmak vizsgálata révén képzelnek el, illetve abban is egyetértenek, hogy az adatok csak saját kontextusukban, társadalmi környezetükben értelmezhetőek megfelelően. Mindkét ág egyetért az egyéni cselekvőképesség fontosságában a társadalmi struktúrák szerepe mellett, illetve elfogadja, hogy a jelentéstársítás folyamata hatalmi mechanizmusok mentén megy végbe, mely a társadalmi valóságról alkotott tudásunkat is befolyásolja. (Hopf [1998], p. 182). Az általam vizsgált etnográfiai módszer és a diskurzuselemzés alapelvei ezek alapján mindkét ág számára perspektívát jelenthetnek, csupán annak kivitelezése különbözhet a felhasznált eszköztár szempontjából.

Az interpretív/kritikai ág fő célja, hogy feltárja a nyelv szerepét a társadalmi valóság közvetítésében és létrehozásában. Ebből fakadóan alapvető módszere nem okokozati viszonyok feltárásán nyugszik, hanem a „hogyan lehetséges” kérdés vizsgálatán, melyet lingvisztikai konstrukciók vizsgálatával hajt végre poszt-pozitivista eszköztár segítségével. Jellegzetes témája például, hogy hogyan keletkeznek és érvényesülnek a nemzetközi normák, illetve milyen nyelvi konstrukciók befolyásolják egy állam identitásának tartalmát, vagy ezeken keresztül a nemzetközi kapcsolatok változásait (Kiss J. [2009], pp. 361-362). Az interpretív/kritikai konstruktivizmus fontos normatív eleme a hatalmi viszonyok vizsgálata, az önreflexivitás, illetve a történések passzív leírása, elemzése helyett az aktív közremüködés és részvétel a normák és diskurzusok formálásában, az emancipáció és az empowerment folyamataiban. A 
konstruktivizmus ezen ága főként Európában terjedt el, fö képviselői David Campbell, Jim George, James Der Derian, R. B. J. Walker, Andrew Linklater és Ann Tickner (Checkel [2008], pp. 72-74., Kiss J. [2009], pp. 360-362; Hopf [1998], pp. 183-184; Jackson-Sorensen [2006], pp. 167).

Az Észak-Amerikából származó konvencionális konstruktivizmus ezzel szemben a pozitivista felfogásból indul ki, és ragaszkodik a hagyományos tudományosság néhány tipikus jellemzőjéhez, mint például, hogy ok-okozati viszonyokat helyez alapvetően magyarázó elemzései középpontjába. Jellegzetes témái a társadalmi normák, aktorok, érdekek és identitások közötti ok-okozati összefüggéseken alapulnak (Kiss J. [2009], p. 360). A konvencionális konstruktivizmus szigorúbb, tudományosabb szerkezetü kereteket ad a kutatásnak, nem törekszik a fennálló viszonyok megváltoztatására, és önreflexivitása is mérsékeltebb, mint az interpretív/kritikai ágé. Emellett határozottan elveti az interpretív/kritikai ág hatalomértelmezését és ehhez kapcsolódó normatív aktivizmusát. A konvencionális konstruktivizmus ezáltal megengedi a „helyes, vagy legalábbis a korábbinál helytállóbb" (Marton et al. [2015], p. 47) tudás felhalmozását, illetve az eredmények minimális szintü univerzalizálását, annak érdekében, hogy határozott álláspontokat képviselhessen, így sokkal közelebb helyezkedik el a realista és liberális típusú univerzális elméletekhez, mint kritikai változata. Ezen ág fő képviselői Alexander Wendt, Peter Katzenstein, Christian Reus-Smit, John Ruggie, Emmanuel Adler, Michael Barnett, és Ted Hopf, akiknek munkásságára jelen kutatás is épül (Hopf [1998], pp. 183-184; Jackson-Sorensen [2006], p. 167).

Jelen értekezés ez utóbbi irányzatot, a konvencionális konstruktivizmus alapvetéseit követi, mely módszertanilag lehetővé teszi a racionalista elméletek több elemének beemelését az elemzésekbe. A kutatás során felhasznált három konstruktivista módszertan mindegyikét konvencionális szempontból közelítem meg. Az etnográfiai módszer ilyen szempontú alkalmazása lehetővé teszi a különböző kategóriák, feltételek és elhatárolások pontos, szigorú meghatározását, akár számszerüsítését. A folyamatkövető elemzések esetében az ok-okozati összefüggések állnak a középpontban, melyek a konvencionális konstruktivizmus jellegzetes vizsgálódási területét képezik (az interpretív ág pedig nem is tekinti ezeket az elemzések fó tárgyának). Bár a diskurzusok elemzése az interpretív ág esetében is jellemzőek, jelen elemzés nem a lingvisztikai kérdéseket helyezi előtérbe, hanem az ok-okozati viszonyok tárgyalását, a jelentéstartalmak változásainak feltárását, illetve a politikai-gazdasági- 
társadalmi kontextus megismerését, megközelítése így szintén a konvencionális konstruktivizmushoz sorolható.

A konstruktivizmus általános kereteinek áttekintését követően az alábbiakban specifikusan a vízügyi kérdések tekintetében vizsgálom meg az elmélet hozzáadott értéket, további szempontokkal egészítve ki második alhipotézisemet.

\subsubsection{Hidropolitikai kérdések konstruktivista elméleti keretben}

A konstruktivista hidropolitika úttörője, Frédéric Julien 2012-ben jelentette meg cikkét, melynek címe Alexander Wendt korszakos munkája [1999] címének parafrazálásával („A hidropolitika az, amivé a társadalmak teszik, avagy miért van szükségünk konstruktivista megközelítésre a víz geopolitikájának vizsgálatában”) elsőként kapcsolta össze explicit módon a konstruktivizmus elméletét és a hidropolitikát. Julien felismerte azt a fentebb már leírt jelenséget, hogy a hidropolitika világában nem jellemző az elméleti megközelítések alkalmazása, illetve azt, hogy ha mégis előtérbe kerül ez az aspektus, akkor a hagyományos realista és liberális elméletek mentén valósul meg a vízkészletek teoretizálása. Jelen értekezés célkitüzésével összhangban Julien is amellett érvel, hogy a konstruktivista elméleti keret, azon belül is a biztonságiasítás, jelentős hozzáadott értéket ad a hagyományos racionalista elméletekkel összehasonlítva.

A konstruktivista elméleti keret lehetővé teszi a hidropolitikával kapcsolatos racionalista elméletekben fontos szerepet játszó vízszűkösség (legyen az abszolút vagy relatív) alapfogalmának tovább bontását, elemzését, hiszen ezt is társadalmi konstrukciónak tekinti: „Vízszükösség akkor áll fenn, ha bizonyos társadalmi szereplők bizonyos okok miatt úgy döntenek” (Trottier [2008], p. 198). A vízszűkösség továbbá a vízkészletekhez társított szimbolikus jelentéstartalmaktól is függ: lehet az „stratégiai erőforrás, gazdasági jószág, vagy valami más (emberi jog, Isten ajándéka, a Föld ereiben áramló vér)" (Julien [2012], p. 58), melynek függvényében más-más mennyiség jelenti az elegendőt. A racionalista elméletek determinizmusából fakadóan mind a neorealista, mind a neoliberális elemzések egyoldalúan látják a vízmegosztással összefüggő államközi kapcsolatok alakulását: vagy a konfliktust, vagy az együttmüködést tekintik meghatározónak. Valójában azonban minden vízmegosztással összefüggő államközi kapcsolatrendszer jóval komplexebb ennél, és egyszerre tartalmazza az együttmüködés és a konfliktus alkotóelemeit (Zeitoun-Mirumachi [2008], pp. 301-303). 
Julien a barátságosság és ellenségesség klasszikus wendti konstrukcióit is megvizsgálja a vízkérdések tekintetében, összekapcsolva ezt azzal az (mind a neomalthusiánus, mind a bőségszaru-megközelítésben megjelenő) állásponttal, miszerint az államközi kapcsolatok általános jellege határozza meg a vízmegosztással összefüggő kapcsolatok jellegét is. Ezzel ismételten felhívja a figyelmet arra, hogy a konstruktivista keretek alkalmazásával ezek a folyamatok, illetve azok dinamikussága sokkal inkább megérthető. A barátságosság általános diskurzusában tehát a vízügyi kérdésekben is nagyobb az esélye az együttműködésnek, míg az ellenségesség diskurzusában a vízügyi feszültségek növekedése várható. Ezek a diskurzusok azonban változhatnak, az egykor barátságos viszonyok elmérgesedhetnek, az ellenségesség pedig enyhülhet, és együttmüködésbe is átfordulhat, a jelentéstársítások interszubjektív folyamatai révén, ami egyértelműen azt mutatja, hogy a vízmegosztással összefüggő államközi kapcsolatok nem tekinthetőek determináltnak. Az is látható, hogy a hagyományos racionalista elméletek képesek arra, hogy feltárják a logikai összefüggést az általános államközi kapcsolatok és a vízmegosztási kérdések között, a konstruktivizmus azonban lehetővé teszi, hogy emögé nézzünk, megvizsgálva és magyarázatot adva a barátságosság és ellenségesség diskurzusainak kialakulására és változásaira.

Wendt parafrazálása tehát valóban megállja a helyét: a hidropolitika az, amivé a társadalmak teszik. Ennek a gondolatnak a felismerése pedig tovább mozdítja elöre a vízügyi kérdések konstruktivista keretben való teoretizálását. A konstruktivizmus azonban, mint ahogyan azt fentebb tárgyaltam, egy igen széles és igen elméleti keretet jelent, melynek alkalmazása a mindennapi gyakorlatban és a döntéshozók számára nem feltétlenül jelent kézzelfogható útmutatást a vízmegosztási kérdések kezelésére, a problémák megoldásának megtalálására, és nem ad konkrét eszköztárat a megoldások megvalósítására. Az elmélet és a gyakorlat összekötése azonban elengedhetetlen, hiszen, amint az az 1.1. és 2.1 alfejezetben is látható volt, a vízügyi kérdések a közeljövőben egyre jelentősebbé válnak majd a nemzetközi kapcsolatok tekintetében. Ebben nyújtanak segítséget a középszintű elméletek, melyek közül jelen értekezés szerzője a koppenhágai iskola munkásságát látja leginkább relevánsnak a vízmegosztási kérdésekkel összefüggő államközi kapcsolatok alakulásának vizsgálatában.

\subsubsection{A koppenhágai iskola elmélete: Szektorelmélet és biztonságiasitás ${ }^{12}$}

\footnotetext{
${ }^{12}$ A fejezet anyaga kis változtatásokkal publikálásra került a következő formában: Szálkai Kinga [2015]: „Előszó: Szektorelmélet és biztonságiasítás.” In: A biztonság szektorális értelmezése. Új kihívások a kutatás napirendjén. Szerk.: Szálkai Kinga - Stepper Péter. Publikon Kiadó, Pécs. 7-20.
} 
A koppenhágai iskola elméleti kerete tipikusan konvencionális konstruktivistának tekinthető, amiben nagy szerepet játszott kialakulásának és fejlődésének története. Az elmélet tulajdonképpen két külön elméletre, Barry Buzan szektorelméletére és Ole Wæver biztonságiasítás-elméletére épül, amit egy gyakorlatibb megközelítés, a regionális biztonsági komplexumok elmélete egészít ki (melyet jelen kutatás a következő alfejezetben vizsgál részletesebben). Az alapvetően realista gyökerekkel rendelkező Buzan kezdetben egy államközpontú, neorealista nézőpontból képzelte el a biztonság fogalmának bővítését (ld. az 1983-ban publikált People, States and Fear c. kötetet). A koppenhágai iskola elméletének legalapvetőbb összegzéseként számon tartott Security: A New Framework for Analysis c. munka már az állam keretein túlra tekintve fogalmazta meg a biztonság szektorális értelmezését (Buzan et al. [1998], p. 8). Wæver biztonságiasítás-elmélete továbbá egyértelműen a konstruktivizmus irányába mozdította a koppenhágai iskolát, a biztonságpercepciók szerepére és az azokat közvetítő diskurzusokra helyezve a hangsúlyt. Buzan és Wæver elméleteinek összekapcsolása módszertani ellentmondást hordoz magában, mivel a szektorelmélet alapvetően pozitivista módszereket alkalmaz, míg a biztonságiasítás elmélete posztpozitivistának tekinthető. Ezt az ellentmondást a koppenhágai iskola egy konvencionális konstruktivista megközelítéssel oldja fel, melynek legfőbb jellemzője, hogy feltételezi, a kialakult társadalmi valóság megfelelően hosszú ideig állandóságot mutat ahhoz, hogy pozitivista módszerekkel is vizsgálható legyen (Mutimer [2013], p. 73).

Az elmélet értelmezése szerint a biztonsági kihívás ,,az az állapot, amikor egy problémát úgy értelmezünk, hogy fennállása létében fenyeget egy adott vonatkozási tárgyat (hagyományosan, de nem szükségszerüen az államot, beleértve a kormányzatot, a területet és a népességet)" (Buzan et al [1998], p. 21). Látható, hogy a biztonság túlélésként való értelmezése a hagyományos racionalista elméletekhez hasonlóan a koppenhágai iskola elképzelésében is meghatározó szerepet játszik, a fentiek alapján ugyanis nem alakulhat ki biztonsági kérdés létfenyegetettség nélkül. A túlélés mellé azonban bekerül a biztonságpercepció konstruktivista fogalma is, hiszen a biztonsági fenyegetések nem objektíven, önmagukban véve léteznek, hanem a releváns szereplők biztonságérzékelése dönti el, mit tekintünk annak. A vonatkozási tárgy (referent object) „olyan dolog, amelynek létére nézve fenyegetést érzékelünk, és amely túlélését indokoltnak, [értékesnek] látjuk” (Buzan et al. [1998], p. 36). 


\subsubsection{A szektorelmélet}

A hagyományos biztonságfogalom vonatkozási tárgya az állam, a koppenhágai iskola azonban számos más esetben is értelmezhetőnek tekinti a fogalmat, például az állami szuverenitás, az állami kormányzat, a nemzetgazdaság, a világgazdaság, a minket körülvevő természeti környezet, vagy akár egy ideológia vagy identitás esetében is. Látható, hogy ezek az esetek nagymértékben különböznek egymástól, és vizsgálatukhoz más-más nézőpontok, eszközök szükségesek. Erre a problémára jelent megoldást Buzan szektorelmélete, mely a vonatkozási tárgyak és a megfigyelt interakciók típusai szerint bontja fel az érzékelt valóságot katonai, politikai, gazdasági, szocietális ${ }^{13}$ és környezeti szektorokra. A szektorális megközelítés az adott elemzés célkitüzéseinek megfelelően elkülöníti a valóság egy szegmensét, ahol a vizsgált probléma lehatárolása könnyebbé válik, a kérdés összetett voltából fakadó nehézségek leegyszerüsödnek (Buzan et al. [1998], p. 8). Fontos azonban kiemelni, hogy a szektorok az elemzés, és nem a valóság egyszerüsítését szolgálják, a biztonság szektorokra bontása azt a célt szolgálja, hogy a külön-külön megvizsgált elemek újra-összeillesztése által egy áttekinthetőbb képet kapjunk (Buzan et al. [1998], p. 167). Bár a szektorelmélet igen közel áll a hagyományos racionalista elméletek alapvetéseihez, a folyamatkövető elemzés módszertanának bemutatásánál hangsúly helyeződik erre a dimenzióra is, így érdemes ezeket a szektorokat itt külön-külön is áttekinteni, és megvizsgálni, hogyan válhatnak ezek relevánssá a vízügyi kérdésekkel összefüggő államközi kapcsolatok tekintetében.

A katonai biztonság szektora nagyrészt párhuzamba állítható a katonai biztonság hagyományos fogalmával. Buzan megfogalmazása szerint „egy kétszintü kölcsönhatásról van szó az állam katonai offenzív és defenzív képességeit és az államok egymásról kialakult biztonságpercepcióit illetően" (Buzan et al. [1998], p. 8). Ez a megfogalmazás a kibővített biztonságfogalom értelmében nemcsak államokra, hanem az államhatárokon belül vagy azoktól függetlenül kialakuló aktorok esetében is érvényes. A szektorban értelmezett kihívások általában katonai eredetűek, az államon belüli fenyegetések esetében például militáns szeparatizmus, forradalmi mozgalmak, terrorista szervezetek vagy bünügyi hálózatok lehetnek a kihívás forrásai, de nem katonai eredetü kihívásokra adott katonai válaszok is elképzelhetőek (Buzan et al. [1998], p. 50). Ez utóbbi aspektus szorosan összekapcsolódhat a vízmegosztással

\footnotetext{
${ }^{13}$ Gyakran találkozhatunk a „társadalmi biztonság” kifejezés használatával, a kötet szerzői azonban úgy vélik, hogy ez félrevezető lehet, hiszen a szektor legalapvetőbb vonatkozási tárgya nem a társadalom (különösen nem a nemzetállam társadalma), hanem az azt alkotó vagy azon kívül létező csoportok identitása. Buzan és szerzőtársai is kiemelik, hogy ,a szocietális (societal) biztonság nem azonos a társadalmi (social) biztonsággal” (Buzan et al. 1998, p. 120).
} 
összefüggő államközi kapcsolatokkal, hiszen a vízkészletek visszatartása, a vízmegosztással kapcsolatos megállapodások megszegése, vagy a határon átnyúló folyók vízhozamát korlátozó létesítmények kiépítése egyaránt kiválthat katonai válaszokat az ezeket létfenyegetettségként érzékelő államok részéről. A másik oldalon a vízkészleteket visszatartó állam is felvonultathatja katonai erejét döntésének kikényszerítésére, vagy az általa épített létesítmény védelmére. Jó példa erre az az eset, amikor az 1990-es évek elején az Atatürk gát víztározójának feltöltése komoly feszültségeket váltott ki Irak, Szíria és Törökország között. Irak a gát lebombázásával fenyegetett, míg Törökország készenlétbe állította haderejét annak megvédésére (Jongerden [2010], p. 138).

A politikai biztonság vonatkozási tárgyai ,az államok és kormányzatok szervezeti stabilitása és az ezeknek legitimitást adó ideológiák” (Buzan et al. [1998], p. 8). A biztonsági fenyegetések fó célpontja tehát a szuverenitás, ami az állam és a nemállami szereplők szervezeti stabilitásában és ideológiai pilléreiben, valamint a nemzetközi rendszer szintjén létező rezsimek (nemzetközi jog, nemzetközi társadalom) müködésében manifesztálódik. A politikai típusú fenyegetések a gyakorlatban ennek értelmében egyrészt egy politikai egység belső legitimitásának megkérdőjelezésén alapulnak, vagyis az entitás lényegét alkotó ideológiai pilléreket vonják kétségbe. Másrészt kívülről is érkezhet a fenyegetés, ilyenkor az entitás legitimitásának külső dimenziója, elismerése kérdőjeleződik meg. (Buzan et al. [1998], pp. 144-145). A vízmegosztással összefüggő államközi kapcsolatok esetében elmondható, hogy a vízkészletek feletti szuverenitás kérdése meghatározó lehet egy állam vagy egy kormányzat legitimitásának biztosításában. Így ennek bármilyen formában megvalósuló csorbítása, kétségbe vonása, vagyis az adott állam vízkészleteinek befolyásolása ezekben az esetekben a politikai biztonság szektorában is biztonsági fenyegetésként jelenhet meg. A vízmegosztással kapcsolatos rezsimeket megkérdőjelező viselkedés szintén értelmezhető a politikai biztonság szektorában. Ez kiválóan látható például Kirgizisztán esetében, ahol a vízkészletek szűkössé válása, a lakosságot is érintő növekvő vízhiány, illetve az ebből eredeztethető energiahiány számos szerző szerint nagy szerepet játszott a 2005-ben és 2010-ben kirobbant kirgiz forradalmak során (Wooden [2014]).

A gazdasági biztonság ,a gazdasági és pénzügyi erőforrásokhoz, valamint a piacokhoz való hozzáférés biztonságát jelenti, ami szükséges az elfogadható jóléti szint eléréséhez” (Buzan et al. [1998], 8). A gazdasági biztonság vonatkozási tárgyainak köre értelmezéstől függően igen széles lehet, az egyénektől indulva a társadalmi csoportokon 
és osztályokon keresztül az államon és a nemzetközi szervezeteken át egészen a nemzetközi gazdasági rendszerig terjedhet, mindezen aktorok szempontjából értelmezhető ugyanis a jólét fenntartásához szükséges erőforrásokhoz való hozzáférés biztonsága. A szektor jellemző kihívásai lehetnek például a gazdasági függőségekből és az ellátásbiztonságból származó kérdések, az egyenlőtlenségek növekedése, a pénzügyi válságok hatásai, az illegális kereskedelmi hálózatok tevékenységének hatásai, a nemzetközi gazdasági rendszer válsága, illetve akár a katonai erő bázisául szolgáló gazdasági erőforrások előteremtésének kérdése (Buzan et al. [1998], p. 98). A határon átnyúló vízfelületek esetében egyértelműen jelen van a gazdasági függőségek és az ellátásbiztonság kérdése, mely ezekben az esetekben több állam együttmüködésére van utalva. Közvetett formában mindez szorosan összekapcsolódhat a társadalmi egyenlőtlenségek kérdésével is. Üzbegisztán példája jól mutatja a határon átnyúló vízfelületek megosztásának gazdasági dimenzióját. Az állam mezőgazdaságában ugyanis hagyományosan kiemelt szerepet tölt be a gyapotágazat. Az ennek fenntartásához szükséges öntözést több államon áthaladó nemzetközi folyók vize biztosítja, Üzbegisztán mezőgazdasága így nagymértékben függ azok vízügyi tevékenységeitől.

A szocietális biztonság egyes csoportok „hagyományos nyelvi, kulturális, vallási és nemzeti identitásának, szokásainak fenntarthatóságát jelenti, a fejlődés elfogadható feltételei mellett” (Buzan et al. [1998], p. 8). Ez a fogalom szintén bővíti a biztonság szereplöinek körét a hagyományos biztonságértelmezésekkel összehasonlítva. A nemzetállam csak abban az esetben lehet vonatkozási tárgya a szocietális biztonságnak, ha a nemzet és az állam határai egybeesnek - ami meglehetősen ritka jelenség. A szocietális biztonság szektorának központi fogalma ugyanis az identitás, mégpedig a társadalmilag konstruált kollektív identitás, ami egy adott közösség tagjaként jelöli meg az egyént, legyen az a nemzet, egy adott etnikum vagy vallás. A vonatkozási tárgyak ennek értelmében igen sokszínűek lehetnek: törzsek, klánok, nemzetek, etnikumok, civilizációk és vallások. Az egy államon belüli különböző identitással rendelkező csoportok eltérő vízhozzáférési lehetőségekkel rendelkezhetnek, mely bizonyos esetekben éppen az adott állam kisebbségei számára jelent fenyegetést, akár fizikai értelemben, akár az elvándorlás, vagy a hagyományos identitás átalakulásának értelmében. Jó példa erre az üzbegisztáni karakalpak kisebbség, melynek területei az Aral-tó mentén helyezkednek el. A karakalpakok a térségben bekövetkezett környezeti katasztrófa révén nem tudják tovább folytatni hagyományos tevékenységüket, a 
halászatot, ami az életmód és az identitás átalakulásához, illetve nagyarányú elvándorláshoz vezetett (Micklin [2007], pp. 54-57).

A környezeti biztonság ,a lokális és bolygószintü bioszféra fenntartásának képességét jelenti, mely minden emberi tevékenység alapját képezi” (Buzan et al. [1998], p. 8). Értelmezéstől függően két fő vonatkozási tárgy jelenik meg ebben a szektorban, az egyik maga a környezet, illetve annak stratégiai fontosságú elemei, a másik pedig „a civilizáció már elért szintje,” melynek elvesztése „barbárságba” taszítaná az emberiséget (Buzan et al. [1998], p. 75). Buzan és szerzőtársai a fenyegetések átláthatóbb csoportosítására három fő területet különböztettek meg a civilizáció fenyegetettsége szempontjából. Az első azokat a fenyegetéseket tartalmazza, melyeket a természetes környezet jelenthet az emberi civilizációra, az emberi tevékenységektől függetlenül. A második az emberi tevékenységből fakadó veszélyeket foglalja magába a környezetre nézve, melyek a civilizáció számára is kockázatot jelentenek. A harmadik területhez azon emberi tevékenységek tartoznak, melyek káros környezeti hatásai látszólag nem jelentenek veszélyt a civilizációra. (Buzan et al. [1998], pp. 79-80). A határon átnyúló vízfelületek több szempontból is jelenthetnek fenyegetést a környezeti biztonság szektorában, a nemzetközi kapcsolatok szempontjából azonban a második terület a legjelentősebb: a folyók szennyezése, az élővilág pusztulása, a vízkészletek visszatartásának következményei, a vízügyi létesítmények megépítése egyaránt járhat több államot érintő negatív hatásokkal. Erre ismételten jó példa az Aral-tó katasztrófája, mely meghatározó módon átalakította a régióban mind a természetes, mind az épített emberi környezetet.

A szektorelmélet tehát összességében egy hasznos eszközt biztosít ahhoz, hogy a vízmegosztással összefüggő államközi kapcsolatok kérdéseit részleteiben átláthassuk. A biztonság szektorokra bontása révén külön-külön meggyőződhetünk a politikaigazdasági-társadalmi kérdésekben megjelenő problémák és kihívások önálló dinamikájáról, a szektorokat ismét egy egységes képpé összeillesztve pedig fogalmat alkothatunk az adott vízügyi kérdések komplexitásáról, mely közelebb vihet a lehetséges megoldási lehetőségek feltérképezéséhez.

\subsubsection{A biztonságiasítás elmélete}

Buzan szektorelmélete mellett a koppenhágai iskola másik központi gondolata Wæver biztonságiasítás-elmélete, mely azzal foglalkozik, hogy hogyan válik egy adott 
kérdés biztonsági kihívássá, miért tekintenek egyes jelenségeket bizonyos körülmények között biztonsági problémának, míg más esetekben ez fel sem merül (mint például a migráció jelensége). A koppenhágai iskola szerint ahhoz, hogy egy kérdés biztonsági kihívássá váljon, biztonságiasításra (securitization) van szükség. Ez alatt annak a lépésnek a megtételét értik, ,ami a politikát az általánosan véve elfogadott játékszabályokon túlra viszi, és az adott kérdést így egy rendkívül speciális politikaterületként, vagy a politika fölött álló problémaként jeleníti meg” (Buzan et al. [1998], p. 23).

A koppenhágai iskola szerint a kérdések, problématerületek három szinten jelenhetnek meg. Az első a szakmai szint, melyben az adott kérdésről nincs nyilvános vita, a problématerület feldolgozása, vizsgálata, a megoldások keresése az adott területtel foglalkozó szakértők feladata, az állam, a politikai szféra nem érintett a kérdésben. A második szint a politika szintje, melyben a kérdés átpolitizálódik, annak kezelése, a megoldások keresése a politikai szféra alapvető müködéséhez szükséges rendszereken keresztül zajlik. A kérdés ezáltal a közpolitika részévé válik, kormányzati döntések születnek róla, rendezéséhez pedig állami erőforrásokat használnak fel. A harmadik szint a tulajdonképpeni biztonsági szint, ahol a kérdés biztonsági kihívássá válik, vagyis létében fenyegetni látszik egy vonatkozási tárgyat. Ekkor a politikai szféra alapvető müködéséhez szükséges rendszerek már nem elegendőek a kérdés rendezéséhez, ahhoz különleges intézkedéseket kell végrehajtani. A biztonságiasítás folyamata tehát azáltal megy végbe, hogy az adott kérdés a politika szintjéről (ahol a kérdések a politikai rendszer szabályainak megfelelően tárgyalhatóak) átkerül a biztonság szintjére, ahol a túlélés érdekei felülírnak minden egyéb megfontolást (ld. 2. ábra).

Ez a folyamat érhető tetten a vízmegosztással összefüggő államközi kapcsolatokban is: a vízmegosztás egyértelmüen megjelenhet a szakmai szinten, ahol szakmai érvek mentén, a tudományos szférában folyik a vita, például a vízfelhasználás fenntarthatóságát, hatékonyságát, vagy a vízmegosztás racionalizálását illetően. Ebben az esetben a kutatások finanszírozásán túl nincs állami szerepvállalás a folyamatban. A politikai szinten a vízmegosztás kérdése a politika intézményeinek napirendjére kerül, a törvényhozás vízügyekkel kapcsolatos törvényeket hozhat, belpolitikai döntések jöhetnek létre vízügyi létesítmények megépítéséről, vagy nemzetközi szerződések, megállapodások születhetnek a határon átnyúló vízkészletek megosztásának módjairól. A biztonsági szinten a vízszükösség egyértelmü létfenyegetésként jelenik meg valamilyen vonatkozási tárgy (általában az állam) szempontjából a biztonság öt 
szektorában, melynek kiküszöbölése csak sürgős és rendkívüli intézkedésekkel valósítható meg. Ezekben az esetekben már nem megfelelő eszköz az állam mindennapi politikai intézményrendszere, a megoldást azon kívül kell keresni - a legvégső esetben akár fegyveres úton biztosítva a szükséges vízmennyiséget.

A fenyegetés azonban nem objektíven létező, hanem a biztonságpercepciókból származtatható, társadalmilag, interszubjektíven konstruált természetü. A biztonságiasítás egy három lépcsőből álló folyamatként fogható fel, ${ }^{14}$ melynek első eleme az a beszédcselekvési elem, aminek révén a hatalommal rendelkező társadalmi szereplők (politikai és katonai vezetők, az államigazgatás résztvevői, kormányok és tagjaik, lobbiszervezetek és a civil társadalom más nyomásgyakorlásra képes csoportjai (Buzan et al. [1998], p. 40) biztonsági kihívásként jelölik meg az adott jelenséget, és számos fórumon kimondják a problémakör biztonsági kérdéssé válását. (Mindez független attól, hogy az anyagi valóságban valóban megjelenik-e a fenyegetés.) A folyamat megvalósulásához elengedhetetlen a második lépés, a potenciálisan befogadó hallgatóság (audience: közvélemény, politikusok, katonai elit, értelmiség és egyéb elitek) kritikus tömegének megnyerése, ${ }^{15}$ aminek következtében megváltozik a társadalom szubjektív biztonságfelfogása, illetve az abból származó gesztusok. Abban az esetben, amikor ez nem valósul meg, vagyis a megszólított társadalmi közösség nem értékeli meghatározó biztonsági fenyegetésként az adott jelenséget, a biztonságiasítás folyamata sikertelen marad. A megszólított közösség kritikus tömegének elfogadása ezzel szemben legitimálja a biztonságiasítás folyamatának harmadik lépését, vagyis a rendkívüli, a megszokott politikai müködésen túlmutató intézkedések foganatosítását az érzékelt biztonsági kihívás megszüntetésére. Buzan és szerzőtársai nem tartják szükséges kritériumnak a biztonságiasítás megvalósulásához ezen intézkedések tényleges bevezetését (bár ha ez megtörténik, az határozottan mutatja a folyamat sikerét), a hangsúlyt a rendkívüli intézkedések bevezetésének lehetségessé válására helyezik (Buzan et al. [1998], p. 25). A biztonsági kihívás így más eszközökkel is kezelhető, a lényeg, hogy a diszkurzív biztonságiasítási folyamat mellett gyakorlati, „valós” elemek is megjelenjenek. Az intézkedésekre emellett az is jellemző, hogy

\footnotetext{
${ }^{14} \mathrm{Az}$ esettanulmányok vizsgálatánál nem kerül sor a háromlépcsős biztonságiasítási folyamat részletes elemzésére, a szerző adottnak tekinti ezen folyamat végbemenését a vizsgált biztonságpercepciók és diskurzusok hátterében, illetve következtetéseiben a kutatás további irányaként jelöli meg ezen folyamatok részletes feltárását.

15 A demokratikus és az autoriter rendszereknél eltérő a biztonságiasítás folyamatában résztvevő szereplők köre, amire jelen tanulmánykötet nem tér ki részletesen. Hangsúlyozni szeretnénk azonban, hogy ennek ellenére minden társadalmi berendezkedésben megtalálhatóak a biztonságiasításhoz szükséges hatalommal rendelkező szereplők, és az a potenciálisan befogadó hallgatóság, melynek támogatása és elfogadása nélkülözhetetlen a folyamat végbemenéséhez. Ld. Emmers [2013], pp. 134-135.
} 
rendkívül sürgősek, amit az indokol, hogy azonnali cselekvés hiányában az adott vonatkozási tárgy visszafordíthatatlanul sérülhet, megszünhet létezni (Emmers [2013], p. 136).

Egy adott kérdés biztonságiasítása tehát lehetővé teszi bármely szükséges eszköz felhasználását a kihívással való szembenézés érdekében. Buzan és szerzőtársai szerint ennek eredménye lehet ,az ellenzék elhallgattatása, [miközben] a hatalom birtoklói számára lehetőség nyílik arra, hogy saját belső céljaikra használják fel a „fenyegetéseket”, illetve, hogy [ugyanezek a szereplők] kevesebb demokratikus kontroll és korlátozás mellett formálhassanak jogot a kérdés kezelésére” (Buzan et al. [1998], p. 29). A biztonságiasítás tehát alapul szolgálhat a szabadságjogok korlátozására.

Többek között erre vezethető vissza a koppenhágai iskola álláspontja, miszerint a biztonságiasítás „,egy negatív fogalom, ami azt mutatja, hogy a megszokott politikai eszközök kudarcot vallottak a probléma rendezésében” (Buzan et al. [1998], p. 29). A biztonságiasítás folyamata azonban visszafordítható, a biztonságiként kezelt kérdések visszavezethetőek a politikai szférába. Ezt a fordított folyamatot nevezzük biztonságiatlanításnak (desecuritization), ami Buzan és szerzőtársai szerint az optimális hosszú távú megoldást jelenti számos problémára (Buzan et al. [1998], p. 29), az államközi kapcsolatokban pedig lehetőséget biztosít a konfliktusok együttmüködésekkel való felváltására.

A biztonságiasítás elmélete tehát egy gyakorlatban is alkalmazható eszközt biztosít mindannak elemzésére, amit a fentiekben a konstruktivizmus hozzáadott értékéről a kutatás már megállapított. A koppenhágai iskola szerint a biztonság interszubjektív folyamatok révén, társadalmilag konstruált - így nem létezik olyan problémakör, amely önmagában véve biztonsági kérdés lenne. Ennek eldöntése az elmélet szerint a szereplők valóságérzékelése, az adott helyzetben jellemző biztonsági percepciók függvényében alakul, amit a hatalommal rendelkező szereplők által meghatározott irányvonalak, a társadalom helyzetét befolyásoló tényezők, illetve az intézkedésekhez szükséges gazdasági és társadalmi erőforrások megléte is nagymértékben képes alakítani. Az anyagi és szellemi tényezők együttes értelmezése a kérdés biztonságiasításának folyamatában lehetővé teszi a folyamat visszafordítását is a megfelelő jelentéstartalmak konstruálásával, mindezzel lehetővé téve a változást és annak vizsgálatát a kialakult biztonságpercepciókban, az azokat rögzítő diskurzusokban, és az ezeken alapuló államközi kapcsolatokban. A koppenhágai iskola elméletében emellett a politikai-gazdasági-társadalmi kontextus kiemelt szerepe is megjelenik, Buzan és Hansen egyértelműen kimondják, hogy „a biztonsági fenyegetés diszkurzív 
konstrukcióját befolyásolja az adott állam történelme, a földrajzi és strukturális elhelyezkedése" (Buzan-Hansen [2009], p. 34). Mindezek alapján elmondható, hogy a koppenhágai iskola elmélete középszintű elméletként közvetíti a konstruktivizmus hozzáadott értékét a vízmegosztással összefüggő államközi kapcsolatok tekintetében, közelebb hozva ennek elemeit a gyakorlathoz, és eszközöket biztosítva a gyakorlati szakemberek, valamint a döntéshozók számára a megoldási lehetőségek feltérképezéséhez és kivitelezéséhez.

\subsubsection{A hidropolitikai biztonsági komplexumok elmélete}

A politikai-gazdasági-társadalmi kontextus leírásához a koppenhágai iskola elmélete a regionális biztonsági komplexumok elmélete révén járul hozzá, mely egyébként ugyanúgy képes a változások elemzésére és az ideák hatásának számbavételére, mint a biztonságiasítás elmélete. A koppenhágai iskola nagy hangsúlyt fektetett arra a tényre, hogy a globális biztonsági interdependenciák mellett egyértelmüen jelen vannak olyan kérdések, melyek egy adott régióban válnak nagy jelentőségűvé. Buzan már 1983-ban, People, States and Fear c. művében megalkotta a regionális biztonsági komplexum fogalmát, melyet a következőképpen definiált: „olyan államok csoportja, melyek elsődleges biztonsági kérdései elég szorosan összekapcsolódnak ahhoz, hogy reálisan ne lehessen ezeket egymástól elkülönítve kezelni. A biztonsági komplexumok alapvetően tartósak, de nem állandóak, belső szerkezetük pedig nem tekinthető merevnek.” (Buzan [1983], p. 106). A hagyományos biztonsági komplexumok elmélete kiemelte a hatalom megoszlásának fontosságát is az egyes államok között (Buzan et al. [1998], p. 10).

Buzan, Wæver és de Wilde 1998-ban mindezt egy kevésbé államközpontú szemszögből, a biztonságiasítás gondolatát is figyelembe véve fogalmazták újra. Eszerint a regionális biztonsági komplexum „olyan egységekből épül fel, melyek esetében a biztonságiasítás és a biztonságiatlanítás fő folyamatai annyira összefonódtak, hogy biztonsági problémáik nem elemezhetőek és nem oldhatók meg egymástól függetlenül (Buzan et al. [1998], p. 201). Az újragondolt fogalom kiegészült a biztonságpercepciók szerepével a biztonsági komplexum struktúrájának formálásában, illetve a hatalom megoszlása mellett a Wendttől már jól ismert barátságosság és ellenségesség dimenzióinak szerepét is számításba vette (Buzan et al. [1998], p. 201) így egy valós konvencionális konstruktivista keretet hozva létre a regionális biztonsági kérdések vizsgálatára. 
Buzan már 1983-ban hangsúlyozta, hogy a regionális biztonsági komplexumok kötőerejét számos tényező biztosíthatja, melyek közül ő maga a földrajzi, politikai, stratégiai, történeti, gazdasági és kulturális tényezőket emelte ki (Buzan [1983], p. 106). A vízmegosztás kérdései azonban szintén jól illeszkednek az elméletbe, hiszen a határon átnyúló vízfelületekhez kapcsolódó biztonsági kérdéseket egyértelműen nem lehetséges egymástól elválasztva kezelni.

Az elmélet vízkérdésekkel összefüggő relevanciáját már az 1990-es évek közepén felismerték. Michael Schulz 1995-ben fogalmazta meg először a biztonsági komplexumok és a vízügyi kérdések összefonódásáról szóló elméletet. Szerinte akkor beszélhetünk hidropolitikai biztonsági komplexumról, amikor "azon államok, melyek földrajzilag 'birtokosai', technikailag pedig felhasználói a folyóknak, ennek következtében jelentős nemzetbiztonsági kérdésként kezelik ezeket," (Schulz [1995], p. 97) összekapcsolva a nemzetbiztonság és a hidropolitika kérdését. Ez jól szemlélteti azt a jelen értekezés által is osztott álláspontot, hogy az államközi kapcsolatok általános természetének ismerete nélkül a vízügyi kérdések sem értelmezhetőek megfelelően.

Az elméleti keret továbbfejlesztésén dolgozó Anthony Turton további elemekkel egészítette ki a fogalmat, arra a következtetésre jutva, hogy egy hidropolitikai biztonsági komplexumban egy állam stratégiailag olyannyira függő helyzetbe kerül a megosztott vízrendszerektől, hogy ez a függőség egyértelműen alakítani kezdi a vízmegosztásban részt vevő államok közötti kapcsolatokat (Turton [2001], [2006]). Ez a fogalom már nemcsak a politikai, hanem a gazdasági-társadalmi elemek jelentőségét is implikálja.

A magyar szakirodalomban is találunk egy, a regionális biztonsági komplexumok elméletét továbbfejlesztő kutatást (Marton et al. [2015]), amely megalkotja a „kérdésspecifikus biztonsági komplexum” fogalmát. A kérdésspecifikus biztonsági komplexum az egy adott kérdésben interakcióban álló szereplők, állapotok és hatások rendszere, melynek alkotói nem tartoznak szükségszerüen egy földrajzi régióhoz, és „,amelyben a kölcsönhatások e rendszere ténylegesen, azaz adatokkal alátámasztható módon érinti az egyes szereplők - legalább a szereplők egy részének egzisztenciális biztonságát” (Marton et al. [2015], p. 55). A kérdésspecifikus biztonsági komplexumok esetében a hidropolitikai aspektus olyannyira kézenfekvő, hogy a szerzők a biztonságiasítási komplexum társadalmi szerveződésének alapkérdéseinél nem is tudtak elszakadni ettől a specifikus példától, és az alvízi és felvízi szereplők helyzetének különbözőségét használják fel példaként a fenyegető hatások megoszlásának feltérképezéséhez (Marton et al. [2015], p. 57). 
Mindezek alapján az Aral-tó vízgyüjtő területének államai, vagyis a közép-ázsiai régió egy hidropolitikai biztonsági komplexumnak tekinthető, ami jelentősen befolyásolja a térségben a vízbiztonsági diskurzusok alakulását. Ezt a megállapítást értekezésem 3. fejezete támasztja alá, melyben Közép-Ázsia hidropolitikai jellemzőit vizsgálom meg általánosságban véve.

\section{5. Összegzés}

Értekezésem második fejezetének első részében a racionalista elméletek alapvetéseit tekintettem át, különösen a vízmegosztással összefüggő államközi kapcsolatok szempontjából. Ennek során megállapítottam, hogy ontológiai, episztemológiai és módszertani korlátaik következtében ezen elméletek számos szempontot elhanyagolnak a vízmegosztás kapcsán, gyakran determinisztikus módon, pusztán a materiális tényezők jelenlétére alapozva, az ideák, identitások, társadalmi törvényszerüségek, illetve a politikai-gazdasági-társadalmi kontextus szerepét figyelmen kívül hagyva, leegyszerüsítve az ilyen jellegü kérdéseket.

A fejezet második részében a konstruktivista elméleti keret által nyújtott alternatívákat vizsgáltam meg. Mind általánosságban, mind a vízmegosztással összefüggő államközi kapcsolatok specifikus témájában elemeztem a konstruktivizmus alapvetéseit és eszköztárát abból a szempontból, hogy milyen hozzáadott értéket biztosít mindez a neorealizmus és a neoliberalizmus hiányosságainak kiküszöbölésére, különös tekintettel a vízügyi kérdésekre. Az elméleti áttekintés alapján levonható a következtetés, hogy a konstruktivizmus 1) teret enged a változás elemzésének a vízügyi konfliktusok és együttmüködések vizsgálatában. 2) A vízügyi konfliktusok és együttmüködések kialakulásának magyarázatában egyaránt számításba veszi a materiális és szellemi eredetü tényezőket, egységként, kölcsönhatásban értelmezve azokat. 3) Képes arra, hogy a hagyományos racionalista elméletek által alapfogalmakként tekintett fogalmakat (mint például a vízszükösség) elemeire bontsa, és feltárja a hátterükben rejlő mechanizmusokat. 4) A hagyományos racionalista elméletek szűken értelmezett világképéhez képest új elemek vizsgálatát teszi lehetővé, melyek kiszélesítik az elemzés horizontját, és új magyarázó tényezők bevonását eredményezik (kultúra, nyelv), a kontextus feltárása révén is segítve a valóság mélyebb megértését.

A konstruktivista elméleti keret mindezzel valós hozzáadott értékkel bír a hagyományos racionalista elméletekkel szemben a vízmegosztással összefüggő 
államközi kapcsolatok változatosságának vizsgálatában. Ezt a hozzáadott értéket középszintü elméletek közvetíthetik a gyakorlati szakemberek és a döntéshozók felé, mint amilyen például a koppenhágai iskola megközelítése, azon belül is elsődlegesen a biztonságiasítás elmélete. A tényleges bizonyításhoz azonban mindezek gyakorlati alkalmazására is szükség van, amihez a következőkben Közép-Ázsia két, transznacionális vízügyi kérdésekben jelentősen érintett állampárjának, a TádzsikisztánÜzbegisztán és a Kirgizisztán-Kazahsztán diádnak az esettanulmányát használom fel a közép-ázsiai hidropolitikai komplexum keretei között értelmezve. 


\section{3. fejezet}

\section{ESETTANULMÁNY:}

\section{A KÖZÉP-ÁZSIAI HIDROPOLITIKAI BIZTONSÁGI KOMPLEXUM}

Értekezésem harmadik fejezetében három fő célt tűztem ki, melyek segítségével a közép-ázsiai térség egyszerü ismertetésén túllépve, átfogóbb összefüggések rendszerében ismertethetem a régiót. Természetesen így sem maradhat el az esettanulmány régiójának alapvető jellegzetességeinek bemutatása, mely a későbbiekben is keretet ad az elemzett jelenségek értelmezéséhez, ez alkotja első célomat. Másrészt részletesen bemutatom a későbbi vizsgálódások hidrológiai kontextusát, melyről az elemzések során várhatóan már ebben a fejezetben kiderül majd (az elkövetkezők során pedig további bizonyítást nyer majd), hogy nem pusztán materialitása révén befolyásolja a térségbeli államok vízmegosztással összefüggő kapcsolatait. Harmadik célkitüzésem pedig az, hogy teszteljem azon, a 2.4.4. elméleti fejezetben tett állításomat, miszerint a közép-ázsiai térség egy hidropolitikai biztonsági komplexumot képez, melynek a vizsgált diádok integráns részét alkotják.

\subsection{Közép-Ázsia hidrológiai jellemzői}

\subsubsection{Az Aral-tó vízgyüjtö területe}

Közép-Ázsia legmeghatározóbb hidrológiai egysége az Aral-tó vízgyűjtője. Ez a terület Kirgizisztán, Tádzsikisztán, Türkmenisztán és Üzbegisztán nagy részén túl Kazahsztán és Afganisztán egyes régióit is magába foglalja. Kiterjedése $151000 \mathrm{~km}^{2}$. Két legjelentősebb folyója az Amu-darja és a Szir-darja, melyek a régió átlagos évi vízhozamának 90\%-át, illetve az öntözéses gazdálkodás céljaira felhasznált vizek $75 \%$ át adják (McKinney [2004], p. 190), aminek 85\%-a az alvízi államok gazdaságait táplálja (Dinar [2012], p. 129).

Az Amu-darja Közép-Ázsia legnagyobb folyója. Éves átlagos vízhozama $74 \mathrm{~km}^{3}$, míg vízgyüjtő területének kiterjedése 309000 km². $1415 \mathrm{~km}$-en szeli át az Araltó vízgyüjtőjét a Vahs és a Pandzs (oroszosan: Pjandzs) összefolyásától számítva. Több forrás a Pandzs mellékfolyót is beleértve 2540 km-re teszi a folyó hosszát. Mellékfolyóinak nagy része a Pamír láncai között ered, vizeinek 74\%-a 
Tádzsikisztánból érkezik, hóolvadásból és gleccserekből táplálkozva. A folyó az afgántádzsik határ mentén haladva jut el Üzbegisztánba, majd Türkmenisztánba, hogy onnan visszatérjen Üzbegisztánba, és az Aral-tóba torkolljon. Az Amu-darja alsó szakaszán sivatagi és félsivatagi területeken halad át. Itt már nem találkozik mellékfolyókkal, és a párolgás, elszivárgás, valamint az öntözés következtében vizének nagy része elvész, mire a torkolathoz ér (CAWATERinfo [2012]). Az Amu-darja vízgyüjtő területén 43 milliós lakosság él (Amu Darya River Basin Network [2015]).

A Szir-darja Közép-Ázsia második legnagyobb folyója, éves átlagos vízhozama $40,8 \mathrm{~km}^{3}$, vízgyüjtő területének kiterjedése $150100 \mathrm{~km}^{2}$. Hosszát tekintve azonban a Narin és a Kara-darja összefolyásától számítva is jelentősebb a tulajdonképpeni Amudarjánál $(2337 \mathrm{~km})$, a Narin folyót is beleértve pedig, ahogyan egyes források teszik, 2790 km-es hosszával egyértelműen az Aral-medence leghosszabb folyója (ICWC Basin Water Organization "Syrdarya” [2015]). Forrásai a Belső-Tien-san láncai között erednek, gleccserek és hó táplálja azokat. Vizeinek 75,2\%-a Kirgizisztánban ered, majd Üzbegisztánon és Türkmenisztánon áthaladva az Aral-tóba torkollik. A folyó alsó szakaszán, az Amu-darjához hasonlóan, kevés a vízutánpótlás, a nagyarányú vízveszteség jelentősen lecsökkenti az Aral-tóig elérő vízmennyiséget (CAWATERinfo [2012]). A Szir-darja vízgyüjtő területén 20 millió ember él (Bernauer-Siegfried [2012], p. 228).

Az Aral-medence éghajlata alapvetően száraz kontinentális, egyes területeken pedig sivatagi és félsivatagi. ${ }^{16}$ A kevés csapadék nagy része télen hullik, az öntözésre alkalmas folyók áradásai pedig a magashegységi hó és gleccserek olvadása idejére tehetők (McKinney [2004], p. 190). Az Aral-tó vízgyüjtő területén már napjainkban is megfigyelhetőek a klímaváltozás hatásai. Több szakértő szerint ezek a hatások a jövőben súlyosbodhatnak majd. Az ENSZ Éghajlat-változási Kormányközi Testülete (IPCC) jelentése szerint a nyáron hulló csapadék mennyisége várhatóan csökkenni fog, míg a téli számottevően megnövekedhet (Világbank [2013a], p. 2). A magashegységi hóolvadás a felmelegedéssel hamarabb fog bekövetkezni, és a gleccserek olvadása is egyre számottevőbbé válik. Ennek következtében megnövekszik az árvízveszély, és csökken a tározókban felfogható víz mennyisége, ami a nyári időszakban is hasznosítható lehetne. Hosszabb távon a fagyott hórétegek és a gleccserek elolvadása igen jelentősen csökkentheti a rendelkezésre álló vízkészleteket, a permafroszt olvadása pedig földcsuszamlásokhoz, infrastrukturális károkhoz vezethet. Mindezen elemzések

\footnotetext{
${ }^{16}$ Egyes források a szubtrópusi éghajlat jelenlétét is megemlítik a térségben, ez azonban nem jellemzője az Aral-tó vízgyüjtö területének.
} 
azonban hangsúlyozzák, hogy a térség elsődleges vízügyi problémája nem a klímaváltozás, hanem a vízigazgatás hiányosságai (ICG [2014], pp. 7-8).

\subsubsection{Közép-Ázsia és a vizbiztonsági kihívások}

A Közép-Ázsiával kapcsolatos leírásokban gyakran megjelenik a vízhiány, a nem kielégítő mennyiségü és minőségü vízkészletekhez való hozzáférés problémája. A kérdést közelebbről megvizsgálva azonban láthatóvá válik, hogy tudományos értelemben tulajdonképpen nincs szó abszolút vízszükösségről. Az ENSZ Környezetvédelmi Programjának (UNEP) 2008-as besorolása (UNEP [2008]) szerint Kazahsztán, Kirgizisztán és Türkmenisztán nem szenved hiányt vízben az egy főre jutó évi ellátottságot tekintve, míg Üzbegisztán és Tádzsikisztán sebezhetőnek minősül, ami azonban még mindig távol van a szűkösség kategóriájától. Az ENSZ Élelmezésügyi és Mezőgazdasági Szervezete (FAO) Aquastat adatbázisának adatai szerint az egy főre jutó megújuló vízkészletek tekintetében a régió államainak többsége a nyugat-európai államok (Németország, Franciaország) vízellátottságának feleltethető meg, Kazahsztán pedig még ezeknél is jobb helyzetben van (UNESCO [2012]). A michigani egyetem kutatóinak (University of Michigan [2015]) becslései szerint még 2025-ben is elhanyagolhatónak tekinthető lesz a vízkészletek szűkössége egész Közép-Ázsiában.

A vízszűkösség mérésére 1989 óta igen széles körben alkalmazott Falkenmarkindikátor az évi egy főre jutó megújuló édesvízkészletek mennyisége alapján csoportosítja az államokat. Az indikátor szerint vízszűkösségnek kitett államnak tekinthető az, amelyben az évi egy főre jutó megújuló édesvíz-készlet nem éri el az $1700 \mathrm{~m}^{3}$-t. $1000 \mathrm{~m}^{3}$ alatt már valós szűkösségröl beszélhetünk, míg $500 \mathrm{~m}^{3}$ alatt abszolút szükösség áll fenn (Brown-Matlock [2011], pp. 1-2). A FAO [2014] adatai szerint 2011-ben ez az érték Üzbegisztánban $1760 \mathrm{~m}^{3}$, Türkmenisztánban $4851 \mathrm{~m}^{3}$, Tádzsikisztánban $3140 \mathrm{~m}^{3}$, Kazahsztánban $6632 \mathrm{~m}^{3}$, míg Kirgizisztánban $4379 \mathrm{~m}^{3}$ volt. Ezek az értékek is azt mutatják, hogy a térség egyetlen országában sem merül fel a szükösségnek való kitettség, az abszolút szükösségről nem is beszélve.

Más indikátorok vizsgálata azonban azt mutatja, hogy mindennek ellenére a vízhiány gyakori jelenség Közép-Ázsiában. A UNEP adatai szerint szinte az egész régióban túlságosan kihasználtak a vízkészletek, míg a Nemzetközi Vízigazgatási Intézet (IWMI) elemzései azt mutatják, hogy Kirgizisztán, Tádzsikisztán és Üzbegisztán teljes területén vízszükösség figyelhető meg, a térség többi részén pedig hamarosan hasonló állapotok alakulhatnak ki (UNESCO [2012], p. 125). Az Aqueduct adatbázisa a 
vízügyi kockázatokat illetően a „szélsőségesen magas” kategóriában tartja számon Tádzsikisztán („magas”) kivételével egész Közép-Ázsiát. Az adatok és értékelések közötti különbségek egyértelmüen bizonyítják, hogy bár a régió elméletben megfelelő mennyiségü vízkészletekkel rendelkezik lakosságának ellátásához, a gyakorlatban ezen vízkészletek felhasználása olyan formában történik, hogy a térség nagy részén vízhiány keletkezik. Az ICG ([2002], p. 1) szerint Közép-Ázsia államai a kritikus állapotban lévő infrastruktúra és a rossz vízigazgatás következtében másfélszer annyi vizet használnak fel, mint amennyire tulajdonképpen szükségük lenne. Az öntözőrendszerekbe kerülő vízmennyiség átlagosan közel fele vész el, mielött a növényekhez érne.

Mindezt tovább súlyosbítja a térség öt államának földrajzi elhelyezkedése a határon átnyúló folyók forrásaihoz viszonyítva. Kirgizisztán és Tádzsikisztán birtokolja a magashegységi területek nagy részét, ami a régió domborzati adottságai miatt azzal a következménnyel jár, hogy ez a két ország felvízi helyzetéből adódóan egyoldalúan rendelkezhet a vízkészletek közel $80 \%$-a felett. Üzbegisztán, Kazahsztán és Türkmenisztán alvízi helyzetük miatt kiszolgáltatottak, amit a vízigényes gazdálkodási módszerek alkalmazása, különösen a gyapottermesztés esetében, tovább fokoz (ICG [2002], p. 2). Az energiahordozókkal való ellátottság és az energiatermelés szempontjából azonban egyértelmüen a két gazdaságilag fejletlenebb és szegényebb felvízi ország szenved hiányt, míg az alvízi országok jelentős szénhidrogén-készleteik és energiaiparuk révén számottevő exportra is képesek. A vízmegosztás államközi megosztását illetően kialakult feszültségek közvetlen okai tehát a nem megfelelően szervezett vízigazgatásban, a vizek allokációjának hatékonytalanságában rejlenek.

\subsubsection{Vizigazgatási rendszerek Közép-Ázsiában a XX. században ${ }^{17}$}

A történelmi tapasztalatok is azt mutatják, hogy megfelelő vízigazgatási rendszer kialakítása mellett a régióban nem volt jellemző a vízhiány. Közép-Ázsia szovjet időszakában a központi irányítás megfelelő víz- és energiamennyiséget biztosított mind az öt köztársaság számára. Már az 1930-as évektől kezdve új öntözőcsatornák, gátak és tározók százai épültek fel a térségben. A Szovjetunió ugyanis a térség adottságait kihasználva igyekezett növelni mezőgazdasági termelését, különösen a gyapottermesztés területén. A központi gazdasági irányítás erre a célra egy

\footnotetext{
${ }^{17}$ A fejezet részletei publikálásra kerültek a következő formában: Szálkai Kinga [2015]: „A vízmegosztás biztonságiasításának változásai Közép-Ázsiában (1960-2010). In: A biztonság szektorális értelmezése. Új kihívások a kutatás napirendjén. Szerk. Stepper Péter - Szálkai Kinga. Publikon, Pécs. 163-189.
} 
összetett vízmegosztási rendszert hozott létre az öt köztársaságot egy egységként kezelve, ami minden állam számára sajátos szerepet írt elő a munkamegosztásban. Az alvízi államok a gyapottermesztésre, míg a felvízi államok a megfelelő vízmennyiség biztosítására szakosodtak. Ebben a rendszerben a vízmegosztás megfelelő arányú biztosítását központi döntések határozták meg, százalékos kvótákat állítva fel, és elősegítve a gazdasági munkamegosztást az államok között (566. jegyzőkönyv [1987]). Eközben ugyanis egy barterrendszer is létrejött, ami lehetővé tette a vízben gazdag, energiaellátottságban viszont hiányt szenvedő államok számára, hogy vizüket energiára cseréljék. Ennek következtében télen feltöltötték a felvízi országokban kiépített tározókat, majd nyáron ezek segítségével biztosították az öntözéshez szükséges vízmennyiséget. A téli időszakban ezen államok energiaellátását az alvízi államokból érkező olaj, gáz, szén és áram segítségével oldották meg (ICG [2014], p. 3). 1988-ban emellett két vízigazgatási ügynökséget is létrehoztak, melyek a régió két fő folyójának, az Amu-darjának és a Szir-darjának a felügyeletét voltak hivatottak biztosítani. A vízerőmü-rendszerek, víztározók, csatornák és öntözőrendszerek müködtetésének és karbantartásának költségeit Moszkva fedezte (ICG [2002], p. 7). ${ }^{18}$

Bár a szovjet központi irányítás képes volt arra, hogy ellássa a köztársaságokat a megfelelő mennyiségű vízzel és energiával, azt is szükséges kiemelni, hogy ez a gazdasági berendezkedés jelentős károkat is okozott, tehát nem szolgálhat egyértelmü mintaként napjaink vízmegosztási kezdeményezéseihez. A Kara-kum sivatag öntözésére 1988-ban átadott csatorna például az Amu-darja vízhozamának 15\%-át vezette el, miközben az Aral-tó hatalmas területvesztesége ebben az időszakban már mindenki számára nyilvánvaló volt. A kiterjedt öntözési rendszerek gazdaságtalan fenntartásából fakadó környezeti károk következményei még napjainkban is beláthatatlanok (Niyazov et al. [2012], p. 18).

A szovjet példa azonban jól mutatja, hogy a vízmegosztás rendezésének szükségessége elkerülhetetlen feltétele a térség államainak zavartalan gazdasági fejlődéséhez. A közép-ázsiai vízigazgatási együttműködési folyamat a köztársaságok függetlenedése után szinte azonnal megkezdődött. Az öt állam (Kazahsztán, Kirgizisztán, Üzbegisztán, Tádzsikisztán és Türkmenisztán) felismerte, hogy közös vízkészleteik korlátozottsága miatt kooperációra vannak utalva a régió két fő folyóját, az Amu-darját és a Szir-darját illetően.

Nemcsak a relatív vízszükösség indította erre az államokat. Amellett, hogy a folyók alsó szakaszán fekvő államok teljes mértékben kiszolgáltatottá váltak a felső

\footnotetext{
${ }^{18}$ A szovjet időszak vízigazgatási rendszerét az értekezés bővebben tárgyalja az 5.2. fejezetben.
} 
szakaszon fekvők vízzel kapcsolatos döntéseinek, a szovjet kezdeményezésre létrejött barterrendszerből adódóan egy további egyoldalú függőség is kialakult az energiaellátást illetően (A vízügyi szabályozás alapelvei [1970]), tovább erősítve ezzel a geopolitikai helyzet által, vagyis a határokon áthaladó folyók révén kialakult, önmagában is nagyfokú természetes függőséget.

Az egymásrautaltság felismerését mutatja, hogy az államok a függetlenség első évtizedében látványosan mindent megtettek annak érdekében, hogy egy multilaterális szerződéseken alapuló, átfogó vízigazgatási rezsimet hozzanak létre a térségben, ami az együttmüködés révén képes lehet mindegyikük érdekeinek képviseletére és érvényesítésére, és amelynek segítségével a lehető leghatékonyabban lehetnek képesek felhasználni közös szükös vízkészletüket. A rezsim első és legfontosabb eleme az 1992ben megkötött alma-atai egyezmény [1992] volt. Az egyezmény megfogalmazza és összefoglalja a határokon áthaladó folyók megosztásának általános alapelveit, amelyek számos külpolitikai vonatkozással bírnak. Mindezek értelmében kimondja a régió vizeinek közösségét és egységét, és rögzíti a részes államok ehhez kapcsolódó kötelezettségeit. Az egyezmény rendelkezéseinek végrehajtására létrehozza a Vízügyi Koordináció Államközi Bizottságát (Interstate Commission for Water Coordination, ICWC). A Bizottság feladatai között szerepel, hogy további vízügyekkel kapcsolatos szervezetek létrehozását terjessze elő, illetve negyedévente megszervezze a tagállamok találkozóját annak érdekében, hogy fenntartsa és koordinálja az együttmüködést közöttük (7. cikk). Emellett konkrét vízmegosztási irányszámokat is kialakít az egyes köztársaságokra és az egész régióra vonatkozóan, monitoringolja azok megvalósulását, valamint módosítja azokat a változó környezeti hatásoknak megfelelően (8. cikk). A Bizottság két külön szervezettel rendelkezik az Amu-darja és a Szir-darja vizének kezelésére (9. cikk).

A közép-ázsiai köztársaságok az Aral-tó katasztrófájának kezelésére és enyhítésére is külpolitikai közösséget vállaltak az Aral-tó megállapodás (Megállapodás az Aral-tó és környéke válságának közös kezelésére, a környezet állapotának javítására és a társadalmi-gazdasági fejlődés biztosítására az Aral-tó térségében keretei között) [1993]. Az egyezmény közös intézményeket állított fel a vizekkel kapcsolatos kérdések kezelésére, melyek közül a legfontosabb az Aral-medence Válságkezelő Államközi Bizottság (Interstate Council for the Aral Sea Basin Crisis, ICAS), mely különösen a környezetvédelemre és a katasztrófa-sújtotta területek közös fejlesztésére helyezte a hangsúlyt (2. cikk). Az ICAS-ba minden köztársaság öt tagot delegált, találkozóik pedig félévente zajlottak. Ugyanebben az évben, hasonló célkitűzésekkel jött létre a 
Nemzetközi Alap az Aral-tó Megmentéséért (International Fund for Saving the Aral Sea, IFAS)

A vízigazgatási rezsimhez kapcsolódva jött létre a nukuszi nyilatkozat [1995] is, ami a vizeket érintő szorosabb együttmüködés szükségességét hangsúlyozta a középázsiai államok között. A közös vízigazgatási rezsim kialakításának utolsó fontos lépése 1999-ban zajlott le, amikor az ICAS egyesült az IFAS-sal, és ennek következtében egy újraértelmezett IFAS keretei között létrejött egy átfogó regionális szervezet a vízbiztonság és a vízellátás kérdéseinek koordinálására (Megállapodás az IFAS és szervezetei státuszáról [1999]). Míg az ICWC a technikai kérdésekkel foglalkozik, az IFAS jelenleg is a politikai érdekegyeztetés és érdekérvényesítés szervezeteként müködik az öt állam képviselőinek részvételével (Allouche [2007], p. 48). A vízigazgatási rezsim kialakulására jellemző volt, hogy a folyamatot barátsági és együttmüködési egyezmények megkötése kísérte a térségben (Mitchell [2012]).

A közép-ázsiai köztársaságok tehát az 1990-es években, felismerve egymásra utaltságukat, megerősítették külpolitikai kapcsolataikat a vízbiztonság és vízellátás terén; tárgyalásos úton, elméletben minden fél számára megfelelő módon rendezve a vízmegosztás kérdéseit. Az így létrehozott átfogó vízigazgatási rezsim illeszkedett az államok általános külpolitikai kapcsolatrendszerébe, amit a Szovjetunió felbomlása után a közös posztszovjet identitás és a függetlenedésből fakadó közös problémák határoztak meg.

A közép-ázsiai vízigazgatási rendszer azonban napjainkban, a nemzetépítés és a regionális rivalizálás időszakában már nem képes kezelni az államok közötti vízmegosztási konfliktusokat, így a kérdés körül kialakuló feszültségek egyre súlyosbodnak. Ennek közvetlen fő oka, hogy a barteregyezmények a gyakorlatban nem valósultak meg a Szovjetunió központi irányítása nélkül. Az alvízi energiaexportképes országok áttértek a piaci árakra, mire válaszul a felvíziek a rendelkezésükre álló vízenergia hasznosítására törekednek. Ezt kétféle módon képesek elérni. Egyrészt átalakítják a már meglévő erőművek felhasználását - vagyis a téli időszakban energiát termelnek a tározók kiürítésével, míg a nyári időszakban feltöltik azokat. Ez azzal jár, hogy a téli időszakban megnövekszik az árvizek veszélye az alvízi országokban, míg a nyári időszakban nem jut el területükre az öntözéshez szükséges vízmennyiség. Másrészt új vízerőmü-rendszereket terveznek és építenek a folyók felső szakaszán, illetve régi, szovjet eredetű terveket elevenítenek fel energiatermelő képességük növelésére (ICG [2014], p. 3). Az alvízi államok mindezt vízbiztonságuk fenyegetéseként értelmezik, aminek következtében a kapcsolatok az egymással való 
vízmegosztásban leginkább érdekelt államok között romlanak meg leginkább. A bizalmatlanság növekszik, az együttmüködés lehetősége egyre távolabb kerül, míg a feszültségek egyre számottevőbbé válnak - miközben a közép-ázsiai országok között alapvetően fennálló ellentétek (etnikai feszültségek, határviták) súlyosbodásához is hozzájárul a vízügyi kérdés elmérgesedése. Ezekhez az alapvetően fennálló ellentétekhez kapcsolhatóak a közép-ázsiai vízmegosztás körül kialakult feszültségek közvetett okai.

Mindezek alátámasztására és kiegészítésére a következőkben bemutatom a közép-ázsiai térség értekezésemben tárgyalt államait és hidrológiai jellemzőit. Ezek után kutatásom fő kérdéseinek megfelelően a Rogun és a Kambar-ata I. vízerőmürendszerekkel és a körülöttük kialakult konfliktust és együttmüködést tárgyalom.

\subsection{Közép-Ázsia államainak vízbiztonsági helyzete}

\subsubsection{Tádzsikisztán}

\begin{tabular}{|l|c|}
\hline \multicolumn{2}{|c|}{$\begin{array}{c}\text { Tádzsikisztán alapvető jellemzői } \\
\text { (CIA [2014c]) }\end{array}$} \\
\hline Terület $\left(\mathrm{km}^{2}\right)$ & 144100 \\
\hline Népesség (millió fö) & 8,192 \\
\hline GDP (milliárd USD) & 9,242 \\
\hline GDP (egy főre jutó, USD) & 2700 \\
\hline $\begin{array}{l}\text { GDP (ágazati megoszlás, } \\
\%, \text { mg/ipar/szolgáltatás) }\end{array}$ & $27,2 / 21,6 / 51,2$ \\
\hline
\end{tabular}

Tádzsikisztán

Közép-Ázsia legkisebb állama. Éghajlata alapvetően száraz kontinentális, ezt azonban az ország karakterét meghatározó hegyvidékek és magashegységek jelentősen módosítják. Tádzsikisztán 93\%-át ugyanis hegyvidékek, magashegységek borítják, területének közel fele meghaladja a $3000 \mathrm{~m}$

tengerszint feletti magasságot. A domborzati jellemzők jelentősen befolyásolják a hőmérsékleti viszonyokat és a csapadékeloszlást: az évi középhőmérséklet $17{ }^{\circ} \mathrm{C}$-tól -6 ${ }^{\circ} \mathrm{C}$-ig változik. Az évi csapadékmennyiség 70-160 mm az alacsonyabb, sivatagos területeken, míg a magashegységekben akár az $1800 \mathrm{~mm}$-t is elérheti. (Világbank [2013b], pp. 1-2). Tádzsikisztán földrajzi viszonyaiban emellett nagy szerepet játszanak a gleccserek, melyek az állam területének 6\%-át borítják. A gleccserek vizet raktároznak, olvadásukkal befolyásolják a folyók vízmennyiségét. Az Amu-darja vízgyüjtő területének nagy része (mely az ország 88\%-ára terjed ki, míg a Szir-darja vízgyüjtőjének 11\%-a található Tádzsikisztánban (FAO [2014c], p. 4)) a hóolvadás mellett ebből a forrásból nyeri vizeit (Világbank [2013b], pp. 1-2). 
Az egy főre eső évi vízfelhasználás $1762 \mathrm{~m}^{3}$, míg az egy főre eső évi megújuló belső vízkészlet $3140 \mathrm{~m}^{3}$. Az összesített éves megújuló vízkészlet nagysága $21,9 \mathrm{~km}^{3}$. Az éves vízfelhasználás a mezőgazdaságban $10,4 \mathrm{~km}^{3}$, az iparban $0,4 \mathrm{~km}^{3}$, a közösségi vízfelhasználás pedig évi $0,65 \mathrm{~km}^{3}$-at tesz $\mathrm{ki}$, ami összesen $11,2 \mathrm{~km}^{3}$-t jelent (FAO [2014c], p. 6). Az öntözött területek nagysága 674416 ha, ami a megmüvelt területek 91\%-át alkotja (FAO [2014c], p. 11).

A domborzat Tádzsikisztánban nem kedvez a vízigényes mezőgazdasági müvelésnek, a csapadék mennyisége viszont számottevő, abszolút értelemben vett vízszükösségről tehát nincs szó. A vízigazgatás hatékonyságának kérdései azonban Tádzsikisztán esetében is szorosan kapcsolódnak az állam általános biztonságához, különösen gazdasági szempontból. Az itt eredő folyók ugyanis rendkívül alkalmasak vízerőművek müködtetésére, az állam energiaellátásának több mint 98\%-át teszi ki a vízerőművek által megtermelt energia. Kihasználtságuk azonban messze áll a hatékonytól. Az elvben rendelkezésre álló évi 527 milliárd $\mathrm{kWh}$ (a világon a 8. legnagyobb mennyiségü vízenergia-potenciál, ami a világ összes vízenergiapotenciáljának 4\%-át teszi ki) energiának ugyanis Tádzsikisztán csupán 4-5\%-át képes a gyakorlatban elöállítani (A Tádzsik Köztársaság... [2015]).

Ennek egyik fő oka, hogy a villamosenergia-ellátás 91\%-át biztosító (CIA [2014c]) vízerőmü-infrastruktúra elöregedett (a létesítmények és a teljes infrastruktúra 74\%-a 30 évnél régebbi (IHA [2013]), illetve jelentős károkat szenvedett az 1992-től 1997-ig tartó tádzsik polgárháború során. A vízerőművek működése, az előállítható áram mennyisége emellett évszakonként és a vízmennyiség függvényében is változó, a téli időszakban komoly problémákat okoz a rendelkezésre álló villamosenergia szükössége. A Világbank 3100 GWh-ra becsli a téli időszakban hiányzó energiamennyiséget, ami a téli összfogyasztás (11 $200 \mathrm{GWh})$ közel 28\%-át teszi ki (Világbank [2012], p. 5). Mindezek eredményeképpen 2009 telén az elméletben vízenergiával jól ellátható tádzsik háztartások több mint $50 \%$-a fával és szárított tárgyával fütött (IHA [2013]).

A gázalapú energiaellátás eközben 95\%-ban (Parshin [2010]) az Üzbegisztánon keresztül érkező gázra épít, ami kiszolgáltatottá teszi az országot a Dusanbével hagyományosan feszült viszonyt fenntartó Taskent irányába. A tádzsik fél 2010 óta hangoztatja (Eurasianet.org [2012]), hogy Üzbegisztán szisztematikus vasúti blokádot érvényesít, illetve akadályozza a földgázszállításokat is, ami tovább súlyosbítja az energiaellátás helyzetét (Világbank [2012], p. 5). 
A kormányzat becslései szerint az energiaellátásban jelentkező kényszerü korlátozások számottevően befolyásolják a gazdaság termelékenységét (A Tádzsik Köztársaság... [2015]). A Világbank 2012-es jelentése alátámasztja ezt, bemutatva, hogy a felsorolt okok következtében Tádzsikisztán lakosságának 70\%-át érintik áramkimaradások a téli időszakban, ami komoly károkkal jár többek között a termelésben, az üzleti életben, a háztartások müködésében, az egészségügyben és az oktatásban is (Világbank [2012], p. 5).

A fentiek alapján tehát levonható a következtetés, hogy Tádzsikisztán jelenleg nem képes arra, hogy megfelelő mennyiségü energiát biztosítson lakosságának ellátására, ezért a vízenergia felhasználásának növelése, a hatékonyságjavítás, az infrastruktúra bővítése kulcsfontosságú kérdés az állam számára. Ennek a helyzetnek a megváltoztatására Dusanbe nemcsak a szovjet időszakból származó vízerőmü-tervek megvalósítását tervezi, hanem teljesen új erőművek, gátrendszerek és víztározók létesítésén is munkálkodik, ami megváltoztatná az Amu-darja vízhozamának alakulását. Ezen fejlesztések kivitelezése viszont az állam vízfelhasználásának növelését jelentené, és emiatt számos olyan következménnyel járhat, ami feszültségeket eredményez az alvízi államokkal.

Emellett az állam gazdaságának stabilizálásához a termelés növelése is szükséges, aminek következtében az öntözött mezőgazdasági területek növelése is fontos elképzelésként szerepel Dusanbe napirendjén. Bár a mezőgazdasági müvelésre alkalmas földterületek kiterjedése csekélynek mondható, Tádzsikisztán lakosságának 50\%-a a mezőgazdaságban dolgozik, melynek központjai az Amu-darja és a Szir-darja öntözött völgyeiben találhatóak. Az öntözés hatékonyságának növelése és a megmüvelt földterületek kiterjesztése kulcsfontosságú lehet Tádzsikisztán élelmiszerbiztonságának biztosításában (McKinney [2004], p. 202). Már az alma-atai egyezmény [1992] tárgyalásai során is megjelent az érvelés, miszerint az országban a többi köztársasághoz képest aránytalanul kicsi az egy főre jutó öntözött terület kiterjedése, mi több, az egyezmény preambuluma el is ismerte Tádzsikisztán öntözött területeinek növelésének szükségességét. Mindezen célok megvalósítása azonban szintén hozzájárulna az alvízi államokba érkező vízmennyiség csökkenéséhez (ICG [2002], p. 19).

Tádzsikisztán a folyók felső szakaszának birtoklása által stratégiai előnnyel rendelkezik a vízhozzáférés terén, ami által képes lehet egyoldalúan érvényesíteni akaratát ezen a téren, például a politikailag és gazdaságilag egyébként jóval erősebb Üzbegisztánnal szemben, melyet sebezhetősége miatt különösen érzékenyen érintenek Dusanbe tervei. Taskent egyértelműen biztonsági fenyegetésként értékeli ezen 
törekvéseket, és regionális hatalmával igyekszik kompenzálni ezeket, miközben mezőgazdaságának fejlesztése érdekében szintén növelni kívánja vízfelhasználását az egyébként is szükösen rendelkezésre álló forrásokból (ICG [2002], pp. 23-24).

Tádzsikisztán stratégiai helyzete azonban jelenleg nem elegendő ahhoz, hogy a természeti erőforrásokban a vízenergiától eltekintve rendkívül szegény, gazdasági és külpolitikai potenciálját tekintve kis jelentőségü állam hatékonyan képviselje érdekeit a vízmegosztás kérdéseiben, és hivatalosan elismertté tegye vízfelhasználásának növelését (Allouche [2007], p. 46; ICG [2002], pp. 19-20). A Rogun vízerőmü-rendszer megépítése jelentős változást eredményezhet Tádzsikisztán stratégiai helyzetének kihasználási lehetőségeiben, tényleges szabályozási lehetőséget biztosítva Dusanbe számára az üzbég területeket ellátó vízkészletek felett, emellett lehetővé tenné azt is, hogy Tádzsikisztán villamos energiát exportáljon a térség államaiba.

\subsubsection{Kirgizisztán}

\begin{tabular}{|l|c|}
\hline \multicolumn{2}{|c|}{$\begin{array}{c}\text { Kirgizisztán alapvető jellemzői } \\
\text { (CIA [2014b]) }\end{array}$} \\
\hline Terület $\left(\mathrm{km}^{2}\right)$ & 199951 \\
\hline Népesség (millió fö) & 5,664 \\
\hline GDP (milliárd USD) & 7,402 \\
\hline GDP (egy före jutó, USD) & 3400 \\
\hline $\begin{array}{l}\text { GDP (ágazati megoszlás, } \\
\%, \text { mg/ipar/szolgáltatás) }\end{array}$ & $19,3 / 31,1 / 49,6$ \\
\hline
\end{tabular}

Közép-Ázsia másik felvízi állama, Kirgizisztán szintén kis területü államnak tekinthető a régió viszonylataiban. Éghajlata alapvetően kontinentális, a magashegységek módosító hatása Tádzsikisztánhoz hasonlóan jelentősen érvényesül. Területének $80 \%$-án a Tiensan és a Pamír hegylánchoz tartozó magashegységek húzódnak, az ország

94\%-a $1000 \mathrm{~m}$ feletti magasságon helyezkedik el, 4\%-át pedig állandóan jég és hó borítja. A kedvezőtlen viszonyoknak köszönhetően a lakosság az állam kiterjedésének csupán 20\%-át kitevő területen él. A hőmérséklet a domborzatnak megfelelően alakul, a völgyekben átlagosan -18 és $28^{\circ} \mathrm{C}$ között lehet. Az évi átlagos csapadékmennyiség 533 $\mathrm{mm}$, de ennek eloszlását is jelentősen befolyásolja a domborzat. A síkságokon ugyanez a mutató $150 \mathrm{~mm}$, miközben a hegyekben akár az $1000 \mathrm{~mm}-\mathrm{t}$ is elérheti. Az állam vízkészleteinek jelentős részét a gleccserek teszik ki, melyek területének 4\%-át borítják (FAO [2014b], p. 1). Kirgizisztán 55,3\%-a a Szir-darja vízgyüjtő területéhez tartozik. A folyó kirgiz szakaszának nagy részén a Narin nevet viseli. Az Amu-darja vízgyüjtő területe is érinti az államot, de kiterjedése nem nevezhető jelentősnek $(3,9 \%)$ (FAO [2014b], p. 4). Az állam vízellátásában fontos szerepet játszik a Toktogul víztározó, 
melynek kapacitása $19,5 \mathrm{~km}^{3}$. A Toktogul elhelyezkedése lehetővé teszi az alvízi országokba érkező vízmennyiség szigorú szabályozását (FAO [1997], p. 128).

Az egy főre eső évi vízfelhasználás $1575 \mathrm{~m}^{3}$, míg az egy főre eső évi megújuló belső vízkészlet $4379 \mathrm{~m}^{3}$. Az összesített éves megújuló vízkészlet nagysága 23,6 $\mathrm{km}^{3}$. Az éves vízfelhasználás a mezőgazdaságban $7,5 \mathrm{~km}^{3}$, az iparban $0,34 \mathrm{~km}^{3}$, a közösségi vízfelhasználás pedig évi $0,22 \mathrm{~km}^{3}$-at tesz $\mathrm{ki}$, ami összesen $8 \mathrm{~km}^{3}$-t jelent (FAO [2014b], p. 6). Az öntözött területek nagysága 1021400 ha, ami a megművelt területek 75,3\%-át alkotja (FAO [2014b], p. 12).

Vízszükösségről tehát Kirgizisztán esetében sincs szó, a vízügyi kérdések leggyakrabban az energiahiánnyal összefonódva kapcsolódnak az állam általános biztonságához. Tádzsikisztánhoz hasonlóan, a magashegységekben eredő folyók hatalmas vízenergia-potenciált hordoznak. Kirgizisztán energiatermelésének $80 \%$-át vízerőművek végzik (a fennmaradó részért szén-, földgáz- és kőolaj-fütésű hőerőművek felelősek). Ezek potenciális teljesítménye évi 160 milliárd kWh energiának felel meg, aminek azonban csupán 10\%-a kerül tényleges felhasználásra. A vízalapú energiatermelés 97\%-át a Narin folyón található hat vízerőmü végzi, melyek közül legutóbb a 360 MW teljesítményü Kambar-ata II. első egységét helyezték üzembe 2010 során (Juraev [2012], p. 2).

A nagyarányú vízenergia-potenciál ellenére a kirgiz energiaszektor súlyos válságban van. Kirgizisztánban az energiaárak rendkívül alacsonyak, az állam maga pedig alapvetően is igen szükös forrásokkal rendelkezik. Az energiainfrastruktúra így meglehetősen rossz állapotban van, ami veszélyezteti az állam energiaellátását, az áramkimaradások rendkívül gyakoriak az országban (ICG [2002], p. 18). A kirgiz hatóságok szerint az infrastruktúra hiányosságai miatt az előállított áram 40\%-a elvész. A vezetékek és a transzmissziós állomások nagy részét teljesen ki kellene cserélni, a forráshiány azonban nem teszi lehetővé a javításokat, a teljes modernizációról nem is beszélve. A veszteség másik részét az áramlopások teszik ki, melyek szintén igen jelentősek az országban (Juraev [2012], p. 4). Az Üzbegisztánból érkező gázellátás gyakori kimaradásai, illetve a Kazahsztánból rendszertelenül érkező szén- és pakurakészletek tovább növelik a kirgiz energiaellátás bizonytalanságát. Az első meghatározó energiaválság 2008 telén sújtotta az országot, az áramkimaradások a fővárost leszámítva egész Kirgizisztánban napirenden voltak. 2014 telén újabb súlyos energiaválság alakult ki. A válságok gazdasági és társadalmi hatásai igen jelentősek, hosszú távon is kielégítő megoldásuk a kirgiz állam egyik legsürgetőbb problémája (Világbank [2015]). 
Biskek a megoldást egy új vízerőmü-rendszer megépítésében látja, a Kambar-ata I. megépítése azonban a Rogunéhoz hasonlóan jelentős ellenállásba ütközik a térségben Üzbegisztán részéről. Bár Kirgizisztán alapvetően igen szegény és kis világpolitikai érdekérvényesítő képességgel rendelkező állam, felvízi helyzete ezúttal mégis lehetőséget adhat terveinek megvalósítására.

Kirgizisztán felvízi elhelyezkedéséből fakadó stratégiai előnyei alapvetően megegyeznek Tádzsikisztánéval, a Toktogul víztározó azonban még Dusanbénál is nagyobb nyomásgyakorló erőt biztosít az állam számára. A Szovjetunió összeomlását kísérő víz- és energiaügyi fordulat is a Toktogul esetében volt a leglátványosabb, amikor Biskek úgy döntött, hogy a számára megfizethetetlen piaci energiaárak hatására megváltoztatja a víztározó müködését, a korábbi módszerrel ellentétben télen kiengedve a rendelkezésre álló vízmennyiséget, csúcsra járatva ezzel erőműveit a leginkább energiaigényes időszakban. Az ekörül kialakult érdekütközéseket pontos adatok segítségével lehet a leginkább szemléltetni: Kirgizisztán energiaigényeinek kielégítésére áprilistól szeptemberig 3,5 km³ , míg október és március között $8,5 \mathrm{~km}^{3}$ víz kiengedése szükségeltetik a víztározóból. Az alvízi országok öntözéses gazdálkodásának hatékony müködéséhez viszont $6 \mathrm{~km}^{3}$ lenne szükséges április és szeptember között, míg a fennmaradó időszakban egyáltalán nincs szükség hozzáadott vízmennyiségre - sőt, a fagyott altalaj és a kialakuló jégtorlaszok miatt a Toktogulból ekkor kiáramló víz súlyos károkat okozhat területükön. Ha Kirgizisztán együttműködik az alvízi államokkal, a termelési időszakban elengedett 2,5 km³ vízmennyiség kb. 2200 millió kWh energiát hoz létre, mely jelentős többlet az ország számára. Elméletben ennek értékesítése megoldást jelenthetne a téli energiahiányra, és elősegíthetné a kooperációt (BernauerSiegfried [2012], p. 233). A nyári energiatöbblet értékesítése azonban a szomszédos államokéhoz képest magas árakból fakadóan nehézkes, a domborzati viszonyok, az infrastrukturális lehetőségek és az államközi kapcsolatok miatt viszont a régión kívüli értékesítés is komoly akadályokba ütközik (ICG [2002], p. 18).

Az energiaválság megoldására így a kirgiz kormányzat szerint a Kambar-ata vízerőmü-rendszer megépítése a legelőnyösebb lehetőség - ez azonban nagyfokú feszültségekhez vezet a régióban. Mivel az üzbég mezőgazdaság egyik legfontosabb területét képező Fergana-völgy ellátását szinte teljes egészében a Szir-darja biztosítja, a két állam közötti viszony nagyban hasonlít a Tádzsikisztán-Üzbegisztán kapcsolathoz, rendszeresen konfliktussal fenyegetve a térséget (Bernauer-Siegfried [2012], p. 232). Mivel Kazahsztán szintén alvízi állam, a nemzetközi kapcsolatok elméletei alapján hasonló feszültségek kialakulása lenne előrejelezhető a Kambar-ata I-gyel kapcsolatban. 
Kazahsztán azonban (és ez képezi az értekezés egyik fö fókuszát), bár valóban nagymértékben kiszolgáltatott Kirgizisztán vízigazgatási tevékenységének, alapvetően a konfliktust és feszültségkeltést kerülve, kompromisszumos utakon igyekszik megoldani vízellátását, és a számára is elfogadható döntések meghozatalára motiválni Biskeket.

Az energiaválság mellett Kirgizisztán számára is fontos kérdés öntözött földterületeinek növelése. Az államban a mezőgazdasági szektor a GDP közel ötödét teszi ki, a foglalkoztatottaknak 48\%-át, míg az export 13\%-át (CIA [2014b], ICG [2002], p. 4). Az előállított javak mennyisége azonban jelentősen kisebb, mint a fogyasztás, a népességnövekedés hatására pedig ez a szakadék tovább növekszik majd, ami veszélyezteti az állam élelmiszer-biztonságát (FAO [2014b], p. 3). A mezőgazdaság lehetőségeinek bővítése tehát nagy jelentőséggel bírna az állam számára, a Kambar-ata I. megépítése pedig ehhez is nagymértékben hozzájárulna.

\subsection{3. Üzbegisztán}

\begin{tabular}{|l|c|}
\hline \multicolumn{2}{|c|}{$\begin{array}{c}\text { Üzbegisztán alapvetö jellemzöi } \\
\text { (CIA [2015d]) }\end{array}$} \\
\hline Terület (km²) & 447400 \\
\hline Népesség (millió fó) & 29,2 \\
\hline GDP (milliárd USD) & 62,62 \\
\hline GDP (egy före jutó, USD) & 5600 \\
\hline $\begin{array}{l}\text { GDP (ágazati megoszlás, } \\
\text { mg/ipar/szolgáltatás) }\end{array}$ & $18,5 \% / 32 \% / 49,5 \%$ \\
\hline
\end{tabular}

Üzbegisztán éghajlata alapvetően száraz kontinentális, az ország $60 \%$-át sivatagi és félsivatagi területek, száraz sztyeppevidékek alkotják (FAO [2014d], p. 1). A hőmérséklet és a csapadékmennyiség a domborzattól függően változik: a nyári középhőmérséklet a keleti határok mentén elnyúló hegyvidéki

területeken kevesebb, mint $22{ }^{\circ} \mathrm{C}$ is lehet, míg a középső és nyugati területeken 28-30 ${ }^{\circ} \mathrm{C}$, ami az egyedi mérési értékek esetében akár az $50{ }^{\circ} \mathrm{C}$-t is átlépheti. Az évi átlagos csapadékmennyiség a sivatagi területeken 80-200 mm között alakul, miközben a hegyvidéki területeken 600-800 mm. A csapadék nagy része télen és tavasszal hullik. A nyarak gyakran szélsőségesen szárazak, Üzbegisztán területének nagy részén ekkor 100 mm-nél is kevesebb a csapadék mennyisége (Világbank [2010], p. 5). Az ország nagy folyói a szárazság miatt kevés vizet szállítanak, a fokozódó vízhiány miatt egyes folyók már korábbi torkolatvidékük elérése előtt kiszáradnak. Az Amu-darja vízgyűjtője az állam 81,5\%-ára terjed ki, míg a Szir-darja vízgyüjtője 13,5\%-ot tesz ki (FAO [2014d], pp. 4-5). 
Bár az évi egy főre jutó megújuló édesvíz-készletek alapján Üzbegisztán nem tartozik a vízszükösségnek kitett államok közé (UNEP [2008]), a száraz éghajlat és a gyapottermesztésen alapuló öntözéses mezőgazdasági müvelés nagy vízigénye következtében az ország szükös vízkészletekkel rendelkezik. Az egy főre eső évi vízfelhasználás $2158 \mathrm{~m}^{3}$, míg az egy före eső évi megújuló vízkészlet $1760 \mathrm{~m}^{3}$. Az összesített éves megújuló vízkészlet nagysága 48,87 $\mathrm{km}^{3}$. Az éves vízfelhasználás a mezőgazdaságban $50,4 \mathrm{~km}^{3}$, az iparban $1,5 \mathrm{~km}^{3}$, a közösségi vízfelhasználás pedig évi $4,1 \mathrm{~km}^{3}$-at tesz ki, ami összesen $56 \mathrm{~km}^{3}$-at jelent (FAO [2014d], p. 6). A mezőgazdasági termelés a GDP 18,5-át teszi ki, és ebben az ágazatban dolgozik a lakosság közel 26\%a. Az öntözött területek nagysága 3700000 ha, ami a megmüvelt területek 88\%-át alkotja (FAO [2014d], p. 14). Az ország az abszolút mértékü vízfelhasználást tekintve a világ élvonalában van, az egy főre jutó vízfogyasztást illetően viszont a középmezőnyben található.

Bár a mezőgazdaság hozzájárulása a GDP-hez 20\% alatt van, az ágazat kiemelkedő jelentőséggel bír Üzbegisztán számára. A lakosság negyede ebbe az ágazatban dolgozik, és az állam történelmi hagyományai révén igen szorosan kötődik a földműveléshez és az öntözéshez. Az öntözéses gazdálkodás és a gyapottermesztés több ezer éves múltra tekint vissza Üzbegisztán oázisaiban és termékeny völgyeiben, meghatározó szerepet töltve be a társadalom és igazgatása fejlődésében. A XX. század elején 1,2 millió hektárnyi területen alakították ki az öntözéshez szükséges körülményeket. 1913 és 1990 között ez a terület 4,2 millió hektárra nőtt, ami a megmüvelt földterületek 82\%-át tette ki (FAO [2014d], p. 11). Az ehhez szükséges vízmennyiség csatornák által történő elterelése számos negatív következménnyel járt, és nagymértékben megváltoztatta a térség vízrajzi viszonyait - Üzbegisztán azonban a Szovjetunió és a világ egyik vezető gyapottermelő államává vált.

Fontos kiemelni azt a tényt is, hogy ugyanebben az időszakban Üzbegisztán lakossága a hétszeresére nőtt, ami azt is jelentette, hogy az egy före jutó öntözött földterületek száma jelentősen csökkent: a 2010-es évekre az 1910 körüli 0,31 hektárról 0,15 hektárra. Ez a világ országainak átlaga $(0,26$ ha/fö) alatt van, méghozzá igen nagymértékben (Abdullaev-Rakhmatullaev [2013], p. 1). Nem véletlen tehát, hogy az üzbég kormányzat gyakran hangoztatja az öntözött földterületek kiterjesztését az állam gazdasági biztonságának megerősítése érdekében.

A Szovjetunió felbomlása óta azonban valójában csökkenésnek indult az öntözött területek kiterjedése, az ehhez szükséges infrastruktúra állapota a karbantartásra fordítható összegek korlátai miatt folyamatosan romlik (FAO [2014d], p. 
11). Ezáltal a vízfelhasználás hatékonysága is csökken, hozzájárulva az ország egyébként sem kielégítő vízellátásának veszélyeztetéséhez. Egyes kutatások szerint a nagyfokú párolgás és az öntözőrendszerek hiányosságai miatt a mezőgazdasági öntözésben alkalmazott vízkészletek 50-80\%-a elvész, mielött elérné a földeket, és csupán 25-35\% kerül hatékony felhasználásra (ICG [2014], p. 4). A vízigényes gyapottermesztés azonban jelenleg is kiemelkedően fontos ágazatát képezi Üzbegisztán gazdaságának, az öntözéshez megfelelő mennyiségü vízkészletekhez való hozzáférés ezért rendkívül nagy jelentőséggel bír az állam számára.

A vízkészletekhez való hozzáférést nagymértékben befolyásolja, hogy Üzbegisztán alvízi államnak tekinthető, ami azt jelenti, hogy folyóinak 80\%-a határain kívül, nagyrészt Tádzsikisztánban és Kirgizisztánban ered (FAO [2014d], p. 6). Bár az Amu-darja vízgyüjtő területe megoszlik Kirgizisztán, Afganisztán és Tádzsikisztán között, a folyó vízmennyiségének nagy része Tádzsikisztánon keresztül éri el Üzbegisztánt (ENVSEC [2011], p. 14). Ez a geopolitikai helyzet sebezhetővé teszi Üzbegisztánt. Annál is inkább, mivel a vízfelhasználás a GDP jelentős részét adó ágazatban, a gyapottermelésre szakosodott mezőgazdaságban bír a legnagyobb fontossággal (Allouche [2007]). Az öntözéses gazdálkodásból származik az állam GDPjének 18,5\%-a, illetve a devizabevételek 20\%-a. A foglalkoztatottak 26\%-a (CIA [2014d]) (más források szerint 40\%-a) dolgozik ebben a szektorban, hatékony müködésének biztosítása tehát a társadalmi stabilitáshoz is nagymértékben hozzájárul. $\mathrm{Az}$ öntözött földterületek 30\%-án gyapotot termelnek, aminek értékesítése az exportbevételek 10\%-át jelenti. Emellett a gabona a legjelentősebb agrárnövény, ami a lakosság élelmezésében játszik kulcsszerepet (GWP CACENA [2011], p. 4). Az üzbég kormányzat mindezek fontosságára és a víz jelentős társadalmi értékére hivatkozva (GWP CACENA [2011], p. 6.) folyamatosan igyekszik növelni az öntözött területek kiterjedését és az öntözőrendszerek hatékonyságát. Mindezek alapján elmondható, hogy a vízmegosztás kérdése rövid távon is egyértelmüen kapcsolódik az ország túléléséhez és általános biztonságához. 


\subsubsection{Kazahsztán}

Kazahsztán alapvető jellemzői

(CIA [2015a])

\begin{tabular}{|l|c|}
\hline Terület $\left(\mathrm{km}^{2}\right)$ & 2724900 \\
\hline Népesség (millió fó) & 18,2 \\
\hline GDP (milliárd USD) & 212,3 \\
\hline GDP (egy före jutó, USD) & 24000 \\
\hline $\begin{array}{l}\text { GDP (ágazati megoszlás, } \\
\text { mg/ipar/szolgáltatás) }\end{array}$ & $4,9 \% / 29,5 \% / 65,6 \%$ \\
\hline
\end{tabular}

Kazahsztán nemcsak a térség területileg legnagyobb állama, hanem világszinten is jelentős, a Föld 9. legnagyobb kiterjedésü országa. Éghajlata száraz kontinentális. Területének több mint 80\%-át sztyeppék és sivatagos, félsivatagos területek borítják. A téli-nyári átlaghőmérséklet az állam déli részein -3 és $30{ }^{\circ} \mathrm{C}$, míg az északi részeken -18-és $19{ }^{\circ} \mathrm{C}$. Az átlagos évi csapadékmennyiség a FAO Aquastat adatbázisa szerint „elenyésző”, 250 mm-re tehető. Vannak olyan területek, ahol a 100 mm-t sem éri el, míg a hegyvidékeken akár 1600 mm is lehet. (FAO [2014a], pp. 2-3). Az elmúlt évek átlagát tekintve megfigyelhető, hogy a klímaváltozás és az emberi tevékenység hatására Kazahsztánban növekszik a vízszükösség (FAO [2014a], p. 6).

Kazahsztán területén négy nagy hidrológiai régió található, ami megkülönbözteti az országot a közép-ázsiai térség többi államától, melyeket jellemzően egy fő vízgyüjtő terület részét képezik. Az Ob, az Aral-tó és a Kaszpi-tenger medencéje mellett Kazahsztánban több nagyobb tó is található, melyek szintén saját vízgyüjtővel rendelkeznek. Az Aral-medence folyói közül a Szir-darja vízgyüjtőjének 43,12\%-a található Kazahsztán területén, míg az Amu-darja nem érinti az országot. A Szir-darja Dél-Kazahsztán és Kizilorda területén az állam egyik legszárazabb részén halad keresztül, ahol meglehetősen problémás a szükséges vízkészletek előteremtése - Almati tartományt is beleértve e három régióban használják fel az öntözésben alkalmazott vízkészletek 90\%-át (FAO [2014a], pp. 4, 10).

Az egy főre eső évi vízfelhasználás 1319 m³ , míg az egy főre eső évi megújuló belső vízkészlet $6632 \mathrm{~m}^{3}$. Az összesített éves megújuló vízkészlet nagysága 107,5 km³ . Az éves vízfelhasználás a mezőgazdaságban $14 \mathrm{~km}^{3}$, az iparban $6,3 \mathrm{~km}^{3}$, a közösségi vízfelhasználás pedig évi $0,88 \mathrm{~km}^{3}$-at tesz $\mathrm{ki}$, ami összesen $21,1 \mathrm{~km}^{3}$-t jelent (FAO [2014a], p. 11). Az öntözött területek nagysága 1182100 ha, ami a megmüvelt területek 98,5\%-át alkotja (FAO [2014a], p. 13).

Az öntözéses gazdálkodás igen nagy szerepet játszik Kazahsztán mezőgazdaságában, annál is inkább, mivel a kevés csapadék és nagyfokú párolgás miatt a víz mesterséges utánpótlása szükséges a termeléshez, különösen az ország déli 
részein. A mezőgazdaságban dolgozó lakosság 1,2 millió főt tesz ki, ami az aktív lakosság 14\%-át jelenti, míg az ágazat a GDP 4,9\%-át adja (CIA [2014a]). Kazahsztán legfontosabb mezőgazdasági terményei közé a gabonafélék, a gyapot és a zöldségfélék tartoznak. Az ország a világ hat legnagyobb gabonatermelöje között van (FAO [2014a], p. 4).

Kazahsztán gazdasági jellegzetességei összességében eltérnek a közép-ázsiai térség államaitól, ami főként abból fakad, hogy a mezőgazdasági termelés a GDP-nek csupán kis hányadát teszi ki. Az ipari termelés közel 30\%-a és a szolgáltatások 65,5\%-a mellett a 4,9\% elenyészőnek tünhet, és a mezőgazdaságban foglalkoztatott lakosság számaránya is alacsony. Kazahsztán így általánosságban véve kevésbé érzékeny a mezőgazdaság kérdéseire, mint például Üzbegisztán, ahol a gyapottermesztés a nemzetgazdaság alapját képezi. Az állam déli területeit tekintve azonban egyértelműen elmondható, hogy a már említett három tartomány, Dél-Kazahsztán, Kizilorda és Almati erősen függ az öntözéshez szükséges vízmennyiség birtoklásától. Alvízi helyzete miatt ez a régió kiszolgáltatott a felvízi országoknak, különösen a Toktogul víztározót üzemeltető Kirgizisztánnak, de az innen érkező vízmennyiség egy része felett rendelkező Üzbegisztánnak is. Asztana stratégiai előnye eközben regionális hatalmi potenciáljában rejlik, gazdasága és politikai ereje sokak szerint Közép-Ázsia vezető államává teszi.

\subsection{A Rogun és a Kambar-ata I. vízerőmú-rendszerek az államközi}

\section{kapcsolatokban}

\subsubsection{Konfliktusok a Rogun vízerömü-rendszer körül ${ }^{19}$}

2014. szeptember 1-jén a Világbank egy régóta várt és világszerte visszhangot kiváltó dokumentumcsomagot hozott nyilvánosságra (Világbank [2014a]). A tádzsikisztáni Rogun vízerőmü-rendszer megvalósíthatóságának vizsgálata 2010-ben indult meg a tádzsik kormány kérésére. A vizsgálat három fő célt tüzött ki maga elé: a tervezett vízerőmü-rendszer technikai, gazdasági, környezeti és társadalmi megvalósíthatóságának értékelését; az energiaellátást biztosítani képes további alternatívák és a különböző gáttervek összehasonlítását; valamint az érintett középázsiai államok (Afganisztán, Kazahsztán, Kirgizisztán, Tádzsikisztán, Türkmenisztán és

19 A fejezet részletei publikálásra kerültek a következő formában: Szálkai Kinga [előkészületben]: „Vízügyi feszültségek Közép-Ázsiában: A Rogun vízerőmü-rendszer kérdése.” In: Megcsalt reményünk. Szerk.: Keller László. XII. Nemzetközi Vámbéry Konferencia, Lilium Aurum, Dunajska Stredá/Dunaszerdahely. 
Üzbegisztán) közötti konstruktív párbeszéd kialakulásának előmozdítását (Világbank [2014b], p. 3). A Világbank elemzéseinek végeredménye az első két pontot illetően egyértelmü: a dokumentumok szerint bizonyos feltételek mellett technikai, gazdasági, környezeti és társadalmi szempontból is a nemzetközi elvárásoknak megfelelően valósítható meg a Rogun vízerőmü-rendszer. A vizsgálat szerint ennek leghatékonyabb formája megegyezik azzal, amit a tádzsik kormány is a leginkább elfogadhatónak tart: a 335 méter magas Rogun e tervek szerint a világ legmagasabb gátja lenne. Mindezen eredményeket beárnyékolja azonban a harmadik célkitüzéssel kapcsolatos elvi javaslatok gyakorlatba való átültetésének kis valószínűsége.

A közép-ázsiai régióban a víz ugyanis kulcsfontosságú és szükös erőforrás, a határon átnyúló folyók vízkészleteinek megosztása a köztársaságok függetlenedése óta számos kérdést vetett fel, melyek nem rendeződtek kielégítően. A vízmegosztás kérdése ezért alapvető konfliktusforrást jelent a térségben, melynek ,állatorvosi lova” a Rogun vízerőmü-rendszer példája, ahol a vízkészleteket mezőgazdaságában nagy mennyiségben felhasználó Üzbegisztán erőteljesen ellenzi az építkezést, és mindent elkövet ennek megakadályozására. A jelenlegi fejlemények alapján ez lehet az első olyan eset is, ahol az érdekütközések a politikai retorikán túllépve gyakorlati következményekkel járnak az építkezést illetően. A kérdés kapcsán a közeljövőben kiderülhet, hogy megvalósul-e a Világbank által előmozdítani kívánt együttmüködés, vagy ehelyett a fegyveres konfliktust előrejelző elemzők előrejelzései bizonyulnak helyesnek.

A Rogun vízerőmü-rendszer Dusanbétól 110 kilométerre, az Amu-darja egyik mellékfolyóján, a Vahs folyón helyezkedik el. A tervezési szakasz 1963-ban kezdődött meg, a tervek 1978-re készültek el. A munkálatok előkészületei már 1976-ban megindultak, de az 1981-ben átadott Nurek vízerömü-rendszerrel való összehangolás miatt módosítások váltak szükségessé, így a tényleges építkezés csak 1982-ben indult meg. 1991-ben a Szovjetunió felbomlási folyamata és a kitörő tádzsik polgárháború következtében leálltak a munkálatok. A felszínen szinte teljesen, míg a föld alatt 70\%ban elkészült vízerőmü-rendszer ezek után számos kárt szenvedett az árvizek révén (Világbank [2014c], p. 6). A polgárháború során a félbehagyott építkezés területén nem maradt megfelelö felügyeleti rendszer, ami tovább súlyosbította a helyzetet - egyes becslések szerint 800 millió USD értékű beruházás ment tönkre.

A munkálatok 2005-ben indultak újra. A 2000-es évek során több, ellentétes eredménnyel járó hatástanulmány készült a vízerőmű-rendszerről. Ezek hatására, illetve az építkezéssel szemben Üzbegisztánban kialakult ellenállás miatt Tádzsikisztán 2007- 
ben a Világbankhoz fordult egy újabb hatástanulmány elkészítése érdekében. A munkálatokat a 2011-ben megkötött megállapodás után meginduló vizsgálatok során, 2012-ben leállították. Jelenleg kérdéses, hogy a 2014-ben megjelent pozitív kimenetelü értékelés után mikor indulhat újra az építkezés.

A Világbank által is elfogadott tervek szerint a Rogun vízerőmü-rendszer egy 335 méter magas gátból, egy 13,3 km³ térfogatú víztározóból, és hat 600 megawattos (MW) turbinából épülhet fel (Menga [2014], p. 5). Az erőmü összkapacitása így 3600 MW (összehasonlításként: a Tiszalöki Vízerőmü 12,9 MW kapacitású), éves villamosenergia-termelése 13300 GWh lenne (Világbank [2014c], p. 6). (Magyarország éves összes villamosenergia-termelése 32478 GWh (EIA [2013])). A Rogun vízerőmürendszer üzembe helyezése szinte kétszeresére növelné Tádzsikisztán (jelenleg 4000 MW-ot kitevő) villamosenergia-termelési kapacitását. A rendszer kiépítésének költségeiről számos becslés látott napvilágot, az Economist szerint akár a hatmilliárd USD-t is elérheti (The Economist [2013]), míg helyi források 2,2 milliárd USD-re (Karimov et al. [2013], p. 241) teszik a szükséges ráfordítások mértékét. Bármelyik becslés is áll közelebb a valósághoz, kérdéses, hogy a 9,2 milliárd USD (CIA [2014a]) éves GDP-vel rendelkező Tádzsikisztán hogyan tudja előteremteni ezt az összeget.

Üzbegisztán álláspontja szerint az építkezés két fő szempontból jelent fenyegetést vízellátására, illetve további környezeti kockázatokat is hangsúlyoz. A hatalmas víztározó megtöltése az ehhez szükséges 8-10 éves periódusban „drasztikus mértékben” csökkentené Üzbegisztán vízkészleteit, az ebből származó károkat 20 milliárd USD-re becslik (Juraev [2012], p. 3). A másik szempont az erőmü folyamatos üzemeltetéséből fakadó vízfelhasználás, ami az üzbég érvelés szerint nemcsak a vízkészletek mennyiségét, de minőségét is csökkentené. A környezeti kockázatoknál kiemelt szerepet játszik a szennyezés kérdése, illetve az esetleges földrengések okozta problémák. A Rogun vízerőmü-rendszer ugyanis egy szeizmikus szempontból aktív területen helyezkedik el, ahol nagy erősségü és viszonylag gyakori földrengések valószínüsíthetőek - melyek a gát sérülése esetén katasztrófához vezethetnek (Keene [2013]). A Világbank hatástanulmánya szerint a térség államainak együttmüködésével a feltöltés időszakában is megoldható a vízkészletek minden fél számára kielégítő megosztása, a folyamatos müködtetés pedig megvalósítható olyan módon is, hogy ne változzon a vízmegosztás mértéke. A tanulmány emellett kizárta, illetve megfelelő körülmények között elhanyagolhatónak minősítette a környezeti kockázatokat (Világbank [2014b], pp. 14-16). 
Üzbegisztán az elmúlt évtizedben minden lehetséges eszközzel igyekezett megakadályozni az építkezést, a határozott diplomáciai ellenzés mellett gyakorlati lehetőségeit is megragadva a nyomásgyakorlásra. Tádzsikisztán közlekedési hálózata ugyanis a szovjet központi tervezésből és a domborzati-politikai viszonyokból fakadóan szinte kizárólag Üzbegisztánon keresztül kapcsolódik a nemzetközi kereskedelem hálózataihoz. Dusanbe álláspontja szerint Taskent 2010 óta lassítja és gátolja a vasúti közlekedést, illetve akadályozza a földgázszállítást Tádzsikisztán felé, egyrészt egyfajta „büntetésként” a már megvalósult elképzelésekért, másrészt pedig azért, hogy a további szankciók elkerülése érdekében a vízerőmü-projektek végleges leállítására késztesse Dusanbét (Nurshayeva [2012]). A két állam közötti ellentét azonban jóval mélyebb, a vízmegosztással kapcsolatos feszültségek pedig jóval széleskörübbek az építkezésekhez közvetlenül kapcsolódó konfliktushelyzeteknél.

Gazdasági szempontból ugyanis mindkét állam biztonsága fenyegetett helyzetben van, érdekeik pedig ellentétesek. A Rogun vízerőmű-rendszer megépítése, mint az a fentiekből kiderült, Tádzsikisztánban megoldást jelentene az államot gyakorlatilag önállósodása óta sújtó energiahiányra, miközben Üzbegisztán számára számottevő problémákat okozna a gazdaság gerincét képező gyapottermesztés tekintetében, ami hosszú távú és szélesebb körü következményekkel is járhat az állam számára. A gyapotmonokultúrával rendelkező Üzbegisztán számára ugyanis a legalapvetőbb gazdasági erőforrások előteremtése nagyon szorosan összefügg a vízigényes növények termesztésével. GDP-jének nagy részét a gyapot révén szerzett jövedelem teszi ki, illetve ez a legstabilabb forrása a külföldi valuta beáramlásának is ennek egyes becslések szerint akár $60 \%$-a is ebből a forrásból származhat (Garcés de los Fayos [2014], p. 7). A termelés egy részének vízhiány miatti kiesése egyértelmü veszélyt jelentene az állam gazdasági biztonságára. Egyes becslések szerint a Rogun vízerőmü-rendszer megépítéséből fakadó károk összege elérheti az évi 600 millió USDt, illetve 2\%-kal csökkentheti Üzbegisztán GDP-jét, továbbá akár 300000 munkahely elvesztését eredményezheti (European Dialogue [2012]).

Társadalmi szempontból ennél is kiterjedtebb az összefüggések láncolata. A Tádzsikisztánban kialakult energiahiány és a gazdaság fejlesztési lehetőségeinek szinte teljes hiánya nagymértékben összekapcsolható a munkanélküliség, a szegénység, a migráció, a csempészet és a kábítószer-kereskedelem problémáival, mi több, a radikális ideológiák térnyerésével is. 2013-ban a népesség 35,6\%-a élt a szegénységi küszöb alatt (1999-ben ugyanez az adat 96\% volt (Világbank [2013c]), és közel hárommillió fő képtelen volt alapvető élelmiszer-szükségleteinek biztosítására. A népesség közel fele 
nem rendelkezik megfelelő ivóvíz-hozzáféréshez. A szegénység és a magas munkanélküliség következtében számos tádzsik vállal munkát Oroszországban, a jelenség elterjedtségét mutatja, hogy hazaküldött jövedelmük a tádzsik GDP 48\%-át teszi ki (HRW [2014], p. 14). A Rogun vízerőmü-rendszer megépítése mindezen problémák kezeléséhez hozzájárulna.

Üzbegisztán számos régiójában eközben a munkaigényes gyapottermesztés körülményei határozzák meg az életminőséget, ami az esetleges vízellátási gondokból fakadó gazdasági problémák esetén hasonló tendenciák megjelenését eredményezheti. Ebben az esetben a politikai elit hatalmának közvetlen forrásaként is értelmezhetjük a vízigényes növények termelését, ami az évszázadok óta hagyományosan jelen lévő patrónus-kliens hálózatok alapját képezi. Ezen hálózatok mentén egyértelmüen, fentről lefelé érvényesül a gazdasági, társadalmi és politikai autoritás és kontroll, egészen az egyszerü kistermelő szintjéig. Ez a legalsó társadalmi réteg fizeti meg a monokultúrák gazdaságtalan fenntartásának árát: a megtermelt gyapotért kapott összegek meg sem közelítik a világpiaci árakat. A korrupció és a nemzetközi segélyek hatékonytalan felhasználása szorosan összefonódik, és hátráltatja a térség öntözőrendszereinek és termelőegységeinek modernizációját (ICG [2014], p. 24).

Mindez elvezet a politikai téren kialakult feszültségforrásokra Üzbegisztán és Tádzsikisztán között a Rogun vízerőmü-rendszer megépítésének tükrében. Politikai szempontból a két állam meglehetősen hasonló helyzetben van. Mindkét országot az egykori szovjet elit és annak leszármazottai irányítják, melyeknek folyamatosan egyensúlyozniuk kell az egyes törzsi, nemzetségi csoportokkal szemben, megvédeni hatalmukat a bel- és külpolitikai kihívásokkal szemben, illetve a lehetőségekhez képest fenntartani az állam és a gazdaság működését (ld. Dobrovits [2011]). Mindebből az következik, hogy a kormányzó hatalom számára nélkülözhetetlen legitimáció a biztonság és a stabilitás megőrzésére épül. A Rogun vízerőmü-rendszer megépítése következményeként a vízbiztonságra irányuló fenyegetések, az esetlegesen bekövetkező vízhiányból eredő gazdasági és társadalmi problémák ezt a sok esetben egyébként is ingatag alapon álló legitimációt vonják kétségbe Üzbegisztánban, míg Tádzsikisztánban éppen az építkezések leállítása fenyeget a gazdasági és társadalmi problémák súlyosbodásával.

Az etnikai feszültségek és a határviták sem mentesek a vízügyi kérdések hatásaitól. Az etnikai feszültségek okai alapvetően a szovjet időkben meghúzott mesterséges határokra vezethetőek vissza, melyek megállapításakor a törekvések ellenére sem tudták kielégítően elkülöníteni egymástól a sokszínű és kevert lakosságú 
régió etnikai entitásait (1d. Szálkai [2012]). A tádzsik többségü Szamarkand és Buhara Üzbegisztánhoz csatolása a mai napig konfliktusforrást jelent az államok közt (Sadykov [2013]). Szorosan idekapcsolódik a határviták kérdése is, amelyek önmagukban is az államok szuverenitását érintik, tehát nagyfokú biztonsági kockázatként jelennek meg. Ezen határviták több helyszínen is kiegészülnek a vízkészletek birtoklásának kérdéseivel, melyek tovább növelik a feszültséget. Jó példa erre a Kirgizisztán területén található Batken régió, ami a kirgiz-tádzsik-üzbég határok találkozásánál terül el, és három enklávét foglal magába. Ezek közül kettő, Szoh és Sahimardan Üzbegisztánhoz, míg Voruh Tádzsikisztánhoz tartozik. Tovább bonyolítja a helyzetet, hogy Szoh lakosságának nagy része tádzsik. 2013-2014 során számos összeütközés történt a különböző etnikumú csoportok között, melyekben a vízkészletekhez való hozzáférés is nagy szerepet játszott (ICG [2014], pp. 9-10). Emellett a nemzetközi viszonyokban a víz diplomáciai fegyverként való alkalmazása is felmerül a határviták és az etnikai feszültségek esetében - ilyenkor zsarolási potenciálként jelenik meg Tádzsikisztán részéről a szükséges vízmennyiség biztosítása Üzbegisztán számára, a válasz pedig Taskent részéről az energiahordozók kereskedelmének felfüggesztése lehet.

A legtágabb értelemben hatást gyakorló feszültségkeltő tényezőnek a nemzet- és államépítés folyamatát tekinthetjük, melynek több szempontból is szerves részét képezi a vízkészletek feletti szuverenitás biztosítása. Mind Üzbegisztánban, mind Tádzsikisztánban jelenleg is a politikai folyamatok egyik legfontosabb részét képezi a nemzetté válás és az államhoz tartozás tudatának kialakítása, megerősítése, ami a politikai elit irányításával zajlik. A vízerőmü-rendszerek, hatalmas gátak hangsúlyozzák az építtető állam hatalmát a természeti erők felett, illetve demonstrálják az együttmüködő nemzeti közösség erejét, ezért fontos szimbolikus erővel bírnak ezen folyamatokban. A Rogun vízerőmü-rendszer építkezései során a tádzsik vezetés nemcsak látványosan megerősíti legitimitásának és hatalmának látszatát, hanem kihasználhatja a lehetőséget arra, hogy elterelje a figyelmet más gazdasági és társadalmi kérdésekről, problémákról, a reformok szükségességéről (Menga [2014], p. 4). Az üzbég vezetés eközben nemzeti erőforrásainak - vízkészletének és gyapottermelésének - védelmét, illetve a Rogun vízerőmü-rendszer révén a vízkészletek feletti feltételezett szuverenitást megkérdőjelező tádzsik ellenségképet használja fel arra, hogy megnövelje legitimitását és szorosabbra vonja az üzbég nemzeti közösséget. A megfelelő vízmennyiség biztosításáért való határozott, szóban akár a katonai beavatkozástól sem elzárkózó fellépés emellett szimbolikus, retorikai erővel is bír, vagyis felhasználható az 
állam erejének demonstrálására a régióban anélkül, hogy tényleges fegyveres konfliktusra kerülne sor.

\subsubsection{Együttmüködési törekvések a Kambar-ata I. kapcsán és azon túl ${ }^{20}$}

2008 során igen súlyos energiaválság sújtotta Kirgizisztánt. Az állam víz- és energiaellátásában fontos szerepet játszó Toktogul víztározó szintje jelentősen lecsökkent, ami veszélyeztette az érintett vízerőművek müködését. 2008 áprilisára a tározóban lévő vízmennyiség a $19,5 \mathrm{~km}^{3}$-es befogadóképességhez képest $6,5 \mathrm{~km}^{3}$-re csökkent, ami $4 \mathrm{~km}^{3}$-rel volt kevesebb a korábbi évinél. A kirgiz kormány számos kényszerintézkedés bevezetésével (például 8-10 órás áramkimaradásokkal) igyekezett kezelni a helyzetet, melyek rövid távon sem biztosítottak megfelelö megoldást. Biskek emellett a vele hagyományosan jó (Wegerich [2008], p. 118), saját jelzője szerint „testvéri” (Kazinform [2011]) kapcsolatokat ápoló Kazahsztán segítségét is kérte. Asztana 250 millió $\mathrm{kWh}-\mathrm{s}$ energiaexporttal járult hozzá a válság kezeléséhez 2008 végén, ami azonban szintén nem jelentett valódi megoldást (Juraev [2012], pp. 1-3). 2010 tavaszán a kormány megkétszerezte a lakosság által felhasznált energia, a víz és a fütés árát, míg az üzleti vállalkozásokat 30\%-os pluszterhekkel sújtotta (Wooden [2014], p. 466). Egy 2009-es interjúztatási folyamat során felmerült a kérdés, „Mi a legkomolyabb probléma, amivel Kirgizisztánnak jelenleg szembe kell néznie?”, amire a megkérdezett 1500 fő 31\%-a a gazdasági problémákat, 28\%-a pedig közvetlenül az energiaválságot jelölte meg. 71,4\% úgy nyilatkozott, hogy az áramkimaradások jelentős hatással voltak lakóhelyükre a 2008-as válság során. A környezeti problémák közül a megkérdezettek nagy többsége a vízügyi kérdéseket emelte ki, hangsúlyozva, hogy ezek megoldása az energiaválságra is megoldást jelentene (Wooden [2014], pp. 46-49).

A kirgiz energiaszektor reformja mindezek alapján elkerülhetetlennek látszik, a megoldási javaslatok pedig a vízerőművek kapacitásának bővítését jelölik meg elsődleges célként. Ezt a kapacitásbővítést az ország vezetése főként a Kambar-ata I. vízerőmü-rendszer megépítésével látja elérhetőnek. Bár a Kambar-ata I. a Rogunhoz hasonlóan fenyegetésként értelmezhető az alvízi államok biztonságára, ez csak Üzbegisztán részéről nyilvánul meg határozottan, Kazahsztán hagyományosan az együttmüködés felé hajlik az építkezést és az elkészülő vízerőmü-rendszer üzemeltetését tekintve is, még az időszakosan kialakuló feszültségek ellenére is. A két

\footnotetext{
${ }^{20}$ A fejezet anyaga kis változtatásokkal publikálásra került a következő formában: Szálkai Kinga [2015]: „Kazah-kirgiz vízügyi megállapodások: A regionális együttmüködés záloga?” AJRC Elemzések, URL jelenleg nem elérhető.
} 
állam alapvetően jó kapcsolatban van, és a közép-ázsiai vízügyi együttműködés úttörői között tartják őket számon. A Kambar-ata I. vízerömü-rendszerről folytatott regionális párbeszéd így sokkal kevésbé terhelt feszültségekkel, mint a hozzá sok tekintetben hasonló Rogun.

A Kambar-ata I. vízerőmü-rendszer Biskektől kb. 150 km-re, a Narin folyón, a Toktogul víztározó közelében helyezkedik el. A tervezési szakasz az 1970-es és az 1980-as években zajlott, a Narin folyó felső szakaszán folyó kiterjedt folyószabályozási munkák részeként, az 1200 MW-os Toktogul, a 800 MW-os Kurpszáj, a 450 MW-os Taskömür, a 240 MW-os Samaldi-Száj és a 180 MW-os Ücs-Kurgán mellett (Rahmetov [2009]). Az építkezés 1986-ban kezdődött meg, 1991-ben azonban, a Rogun vízerőmürendszerhez hasonlóan, a Szovjetunió felbomlásával és az anyagi források elapadásával szünetelni kezdtek a munkálatok.

A kirgiz kormányzat 2003-ban vetette fel újra a Kambar-ata I. vízerőmürendszer megépítésének folytatását (Menga [2014], p. 132), az állam azonban nem rendelkezett ehhez megfelelő forrásokkal. 2009 januárjában Oroszország 1,7 milliárd USD-nyi kölcsönt ígért Kirgizisztánnak a Kambar-ata I. megépítésére (ami közvetlenül megelőzte a manaszi amerikai légibázis bezárását). A terv egy orosz-kirgiz vegyes részvénytársaság megalapítása volt az orosz Inter RAO UES és a kirgiz Elektricseszkije Sztancii 50-50\%-os részvételével (Hydroworld.com [2009]). A gazdasági, pénzügyi és technológiai megvalósíthatósági tanulmány azonban nem készült el, 2009-ben pedig az orosz fél felbontotta az együttmüködést, méghozzá hivatalosan a már megkapott összeg nem megfelelő felhasználása miatt (Roman [2010]). 2012-ben újjáéledt az orosz érdeklődés, Moszkva és Biskek újabb szerződéseket írt alá a projekt közös végrehajtásáról. A tervek szerint a munkálatok 2013-ban kezdődtek volna el, az építkezés pedig 2021-ben fejeződött volna be. 2013 során a megvalósíthatósági tanulmány elkészítésére írtak ki egy ötmillió USD értékű pályázatot, amit a kanadai SNC-Lavalin nyert meg, a tanulmány azonban mindezidáig nem készült el (Rushydro.ru [2012]). Az időközben az ukrán válság és az azt kísérő szankciók miatt átalakult orosz gazdasági helyzet láthatóan nem teszi lehetővé, hogy a tervek szerint folytatódjon a vízerőmü-rendszer megépítése. Mindehhez a jelenlegi állapotok szerint legalább kétmilliárd USD befektetésre, és 8-10, vagy, pesszimistább becslések szerint 10-12 évre lenne szükség (Juraev [2012], p. 2).

1992-ben Kazahsztán és Kirgizisztán megkötötte az első, a Csu és Talasz folyókat érintő különmegállapodást, ami eltért a Szir-darjára elfogadott alma-atai egyezmény rendelkezéseitől (melynek egyébként mindkét állam részese, 
együttmüködésük tehát ebben a formában is tetten érhető). A különmegállapodás nem elözmény nélküli, 1983-ban a Talasz vízgyüjtő területe kapcsán megkötött egyezmény 50-50\%-os vízmegosztást írt elő a két állam számára (Wegerich [2008], p. 121). A Csu és Talasz folyók és vízgyüjtő területük kapcsán kialakult helyzet rendkívül hasonló a Szir-darján kialakulthoz, bár jóval kisebb léptékben. A terület folyóinak nagy része Kirgizisztánban ered, vizük fontos szerepet játszik a két állam mezőgazdasági területeinek öntözésében, amihez vízhozamuknak 90\%-át felhasználják (Demydenko [2004], 31. dia). A Talasz folyó 660 km hosszú, melyből 440 km húzódik kazah területeken, vízgyüjtője $52700 \mathrm{~km}^{2}$, aminek 78,3\%-a található Kazahsztán területén. A Csu 1067 km hosszú, amiből 731 km érinti Kazahsztánt. Vízgyüjtője 62500 km², melynek 57,5\%-a kazah terület (Chu-Talas Commission [2011], p. 5). A Talaszon emellett egy víztározó is található, melynek használata közös érdek a két állam számára. A szovjet időszakban épült, $0,55 \mathrm{~km}^{3}$ kapacitású Kirov tározó Kirgizisztán területén helyezkedik el, létrehozásának fö célja pedig az öntözéshez szükséges vízmennyiség szabályozása volt. Az államok függetlenedése után Kazahsztán és Kirgizisztán közel azonos öntözött földterületekkel rendelkezett a Csu-Talasz medencében (Demydenko [2004], 40. dia). A megállapodás szerint Kazahsztán a Csu vízgyüjtő területén évi 1,24 $\mathrm{km}^{3}$-nyi, a Talasz esetében pedig $0,79 \mathrm{~km}^{3}$-nyi vízkészlet allokációjára jogosult (FAO [2014a], p. 8).

Kazahsztán és Kirgizisztán tehát a Szovjetunió felbomlása után is folytatta az együttmüködést, ami a térség más államaitól eltérően a gyakorlatban is megvalósult bár Kirgizisztán a szovjet időszakkal összehasonlítva kevésbé kiegyensúlyozottabb módon, az adott évi csapadékmennyiségnek megfelelően biztosította Kazahsztán számára az öntözéshez szükséges vízmennyiséget (bizonyítja Wegerich [2008], p. 124).

Az együttmüködés a két állam között 1998-ban tovább bővült, amikor Üzbegisztán bevonásával multilaterális együttmüködési megállapodást kötöttek, melyben korábbi bilaterális szerződések tartalmát összegezve felismerték a felvízi és alvízi országok energiahiányon és a vízkészletek megosztásán alapuló kölcsönös függőségét, és a szovjet barterrendszerhez hasonló rezsimet hoztak létre. A kirgiz vízért cserébe Biskek üzbég gázt, valamint kazah szenet és pakurát kapott (ICG [2002], p. 9). Az egyezmény öt évre vonatkozott, és a kvóták évenkénti újratárgyalását is tartalmazta. Az együttmüködés 2003-ig mérsékelten sikeresnek bizonyult (bár az ÜzbegisztánKirgizisztán közötti barterfolyamat igen hamar felborult), ami azonban még így is kivételt jelent a közép-ázsiai vízügyi egyezmények történetében (Dinar [2012], p. 131). 
A kirgiz-kazah vízigazgatási együttmüködés 2000-ben túllépett ezeken a kereteken, létrehozva a Csu-Talasz megállapodást. A megállapodás kimondta, hogy a Csu és Talasz folyók vizének igazságos és egyenlő megosztása mindkét állam érdeke. Mivel mindkét állam egyaránt használója a folyó vizeihez kapcsolódó infrastruktúrának, az ehhez kapcsolódó kormányköziként megjelölt létesítmények müködtetési és karbantartási költségeit a felhasznált vízkészletek arányában megosztva vállalják. Számos szakértő szerint ez a megállapodás, illetve ennek továbbfejlesztett változata lehet a későbbi regionális vízügyi kooperáció kulcsa (Wegerich [2008], p. 118). A CsuTalasz megállapodás aláírását szinte közvetlenül követően, 2001-ben elfogadott kirgiz vízügyi törvény (A vízügyi objektumok, vízkészletek és vízügyi létesítmények államközi használatáról) kimondta, hogy az állam területén kialakuló vízkészletek Kirgizisztán kizárólagos tulajdonát képezik, így ezekért és az ezekhez kapcsolódó létesítmények fenntartásáért az alvízi államoknak fizetniük kell, ami miatt komoly kritikákkal kellett szembesülnie. Az állam azonban hamarosan finomította álláspontját, és a vízügyi létesítmények fenntartási költségének megosztását javasolta. Kazahsztán esetében a 2000-es megállapodásnak megfelelő, pozitív választ kapott: Asztana 2002ben ratifikálta a Csu-Talasz megállapodást, és az év márciusa óta kb. 100000 USD-nek megfelelő összeget fizet a Csu és Talasz folyók vízügyi létesítményeinek fenntartásáért (ICG [2002], pp. 15-16). (Üzbegisztán ebben a formában is határozottan elutasította a javaslatot.) Az ENSZ Közép-Ázsiai Speciális Programja (SPECA), az EBESZ és az Ázsiai Fejlesztési Bank hatalmas áttörésként igyekezett népszerüsíteni a Csu-Talasz megállapodást, és számos olyan elemzés született, ami ezt a közép-ázsiai vízügyi együttmüködés általános mintájaként mutatta be (Wegerich [2008], p. 118).

A 2000-es szerződésben már megjelent a közös bizottságok létrehozásának gondolata a rendelkezések gyakorlati végrehajtásának elősegítésére. 2006-ban ebbe az irányba folytatódott a Csu és Talasz folyók vízmegosztását érintő együttműködés, és létrejött a Csu-Talasz Bizottság. A kooperáció elősegítésében a nemzetközi közösség is részt vett, az EBESZ, a UNECE és a UNESCAP programja (Support for the Creation of a Transboundary Water Commission on the Chu and Talas Rivers between Kazakhstan and Kyrgyzstan" (Chu-Talas I)) nagymértékben hozzájárult a Bizottság létrehozásához. A Bizottság évente legalább kétszer összeül, munkájában mindkét állam saját testületével vesz részt, melyek saját elnökkel rendelkeznek. A napi feladatokat a Titkárság végzi, mely a Bizottság mindkét testületének titkárságát egyesíti. A szervezet négy tematikus albizottsággal müködik, az egyik a jogi és intézményi kérdésekkel, a másik a vízkészletek allokációjával, a harmadik a technológiai és karbantartási 
kérdésekkel, a negyedik pedig a gazdasági és környezeti monitoringgal és információcserével foglalkozik (Panella [2008], 11-12. dia).

A kirgiz-kazah vízmegosztás adatai azt mutatják, hogy 2006 kivételével Kirgizisztán 1983-tól számítva minden évben teljesítette, sőt, több alkalommal túl is teljesítette vállalt kötelezettségeit a Kazahsztán rendelkezésére bocsátandó víz mennyiségével kapcsolatban. A teljes képhez azonban az is hozzátartozik, hogy a Kirov víztározó üzemeltetése során felmerültek problémák a vízkészletek áteresztésének időzítésével - a termelési időszakban ugyanis több esetben is kevesebb víz jutott a kazah területek öntözésére, ezzel hátrányosan befolyásolva a mezőgazdaság helyzetét (Wegerich [2008], p. 128).

Kirgizisztán és Kazahsztán 2008 és 2011 között a nemzetközi közösség támogatásával dolgozott tovább a Csu-Talasz medencében kialakult együttműködés továbbfejlesztésén az EBESZ és a UNECE közremüködésével. A program (Development of Cooperation on the Chu and Talas Rivers (Chu-Talas II)) keretei között további vízügyi létesítményeket vontak az egyezmény hatálya alá, helyi vízügyi tanácsokat hoztak létre, és az integrált vízigazgatás szellemében fejlesztették a létesítményeket. Emellett közösen felmérték a szerződés hatálya alá tartozó létesítmények állapotát, és tervet készítettek azok közösen végrehajtott karbantartására és felújítására (UNECE [2015]).

A két állam emellett egy közös konzorcium létrehozását is tervezi a Szir-darján, ami lehetővé tenné regionális víz- és energiaügyi programok végrehajtását (ICG [2002], p. 9). A szervezet közös finanszírozásáról 2001-ben előmegállapodást is kötöttek. A regionális víz- és energiaügyi konzorcium gondolata már az 1998-as megállapodásban is szerepelt, később pedig az EurAsEC terveiben is megjelent, napjainkig azonban nem történt gyakorlati elörelépés a kérdésben (ICG [2002]).

Kazahsztán és Kirgizisztán között is megjelennek feszültségek a víz- és energiaügyi kölcsönös függőségek tekintetében. A kazah szénbányák privatizációja például nagymértékben hozzájárul ahhoz, hogy Asztana nem tudja betartani a megkötött barteregyezményt, illetve problémák adódnak abból is, hogy a kirgiz energiaárak magasabbak, és az ennek vásárlására kötelezett Dél-Kazahsztán és Kizilorda hajlamos megkerülni a barteregyezmények rendelkezéseit. Kazahsztán emellett sok adóssággal is rendelkezik Kirgizisztán irányába. Ezek a feszültségek azonban nem a hivatalos állami irányítás oldaláról jelentkeznek, Asztana általában ezek mielőbbi csökkentésén, a barteregyezmények betartásán dolgozik (ICG [2002], p. 15). A Szir-darja 
vízkészleteinek megosztása mindezek révén még Üzbegisztán ellenségességével együtt is sokkal inkább szabályozott, mint az Amu-darja esetében.

\section{4. Összegzés}

Értekezésem harmadik fejezetének megírásakor többoldalú célokat tüztem ki, méghozzá az esettanulmány régiójának általános bemutatását, a hidrológiai kontextus ismertetését, illetve a térség regionális, hidropolitikai biztonsági komplexum voltához kapcsolódó feltételezéseim igazolását. Összegzésül elmondható, hogy mindhárom célkitűzés megvalósult. Az első alfejezetben áttekintettem Közép-Ázsia hidrológiai jellemzőit, bemutatva, hogy a térségben a vízszükösség nem abszolút jellegü, hanem főként a vízigazgatási rendszerek hiányosságaira, illetve a vízmegosztási mechanizmusok elégtelenségére vezethető vissza. A közép-ázsiai vízigazgatási rendszerek bemutatása során az is kiderült, hogy a vízügyi kérdések a régióban nem értelmezhetőek az energiaellátás kérdései nélkül. A Szovjetunió példája jól mutatta, hogy a térség vízkészletei megfelelő koordinációs mechanizmusok révén megfelelően biztosítják minden állam víz- és energiaszükségleteinek kielégítését, az 1990-es évek komplex rezsimjének kudarca révén pedig az is láthatóvá vált, hogy az államok közös politikai akarata nélkül nincs mód arra, hogy rendezzék a vízmegosztás és ezzel együtt az energiaellátás kérdéseit. Ezek a kérdések így biztonsági kérdéssé válnak, a növekvő bizalmatlanság légkörében pedig rendkívül nehéz enyhíteni a kialakult feszültségeket.

Az egyes államok bemutatása a 3.2. alfejezetben további részleteket tár fel a vízügyi feszültségekkel kapcsolatban, de Kazahsztán és Kirgizisztán példáiban az együttmüködés is megjelenik. A 3.3. alfejezetben az államközi feszültségek két ütközőpontját, a Rogun és a Kambar-ata I. vízerőmü-rendszerek példáját emelem ki. A példákban egyértelmủen látható, hogy Üzbegisztán következetesen képviseli mindkét esetben a helyzetéből fakadóan kiszolgáltatott alvízi állam álláspontját, tiltakozva minden olyan létesítmény ellen, mely megváltoztatná az Amu-darja és a Szir-darja vízhozamát. Kazahsztán azonban, a várakozásokkal ellentétben, kilép ebből a narratívából, és, bár bizonyos korlátok között, de hajlandó az együttmüködésre a felvízi Kirgizisztánnal.

A fejezet jól szemléltette a térség regionális/hidropolitikai biztonsági komplexum-jellegét is. A hidrológiai jellemzők leírásából, illetve azoknak az államközi kapcsolatokkal való összevetéséből egyértelmủen láthatóvá vált, hogy a határon átnyúló vízfelületek révén igen komoly interdependenciák jöttek létre az Aral-tó vízgyüjtője 
területén, melyek elsődleges biztonsági kérdések kialakulásához vezettek. Ezek a biztonsági kérdések a határon átnyúló folyók jellegéből fakadóan nem kezelhetőek külön egymástól, illetve a térség államainak további biztonsági kihívásaival is összekapcsolódnak, amint azt a 3.2. és 3.3. alfejezet is bemutatta. (A biztonságiasítás folyamatának alakulását részletesen az 5. fejezetben tárgyalom majd.) A hatalom alvízi és felvízi pozíciókból fakadó megoszlása mellett a wendti ellenségesség és barátságosság dimenziói szintén jól megfigyelhetőek a térségben, ezek gyökerei mindhárom következő fejezetnek tárgyát képezik majd. A vízügyektől való függőség tehát egyértelműen alakítja a vízmegosztásban részt vevő államok közötti kapcsolatokat a térségben.

A kirgiz-kazah együttmüködést leszámítva, Közép-Ázsiában a nagy tendenciák alapján egy vízmegosztási feszültségekkel sújtott régió körvonalai rajzolódnak ki, amely a mai napig kiváló alkalmat nyújt a neorealista vízháború-koncepció követői számára elgondolásaik bemutatására (Trilling [2016]). A konstruktivista elméleti keret szerint azonban jóval több minden rejlik a feszültségek hátterében, mint a materiális vízszükösség, a relatív hasznok maximalizálása, az állami szuverenitás biztosítása az erőforrások felett az állam túlélésének biztosítására, a vízmegosztás kérdésének alapvetően konfliktusos természete, vagy akár egy vízügyi hegemón befolyása. A következő fejezetekben három különböző konstruktivista módszer alkalmazásával mutatom be az elméleti keret hozzáadott értékét a racionalista megközelítésekkel szemben. 


\section{4. fejezet}

\section{AZ ETNOGRÁFIAI MÓDSZER}

\subsection{Az etnográfia mint módszer}

Az etnográfia egyik általános definíciója a fogalmat a következőképpen határozza meg: „az emberek mindennapi életének vizsgálatánál alkalmazott megközelítés, amely különös figyelmet fordít az adott kultúrára, azon folyamatokra, amelyek révén az emberek (néha vitázva vagy egyetértve) jelentést alkotnak." (Anderson-Levitt [2006], p. 279). Az etnográfia módszerként való alkalmazásához elöször is fogalmi tisztázásra van szükség, hiszen a nemzetközi politikaelmélet által módszerként felhasznált, főként amerikai eredetű ,etnográfia” mint szakterület a magyar terminológiában leginkább az etnológiának, és igen kevéssé az általános néprajztudománynak feleltethető meg. A nemzetközi politikaelmélet azonban nem teljes egészében veszi át az etnológiai szemléletet, pusztán eszközeit igyekszik saját területén alkalmazni. Ezért a továbbiakban etnográfiai módszerről fogok beszélni, amivel az eszközközpontúság mellett arra kívánok utalni, hogy a föként amerikai eredetű etnográfia az a tudományág, melynek módszereit egyre többen igyekeznek átemelni a nemzetközi politikaelmélet megújítására.

Az 1980-as években kezdődött el az a folyamat a tudományágon belül, amit etnográfiai fordulatnak neveznek. Az etnográfia definíciója ebben a tekintetben a következő: „a kultúra empatikus elemzése, ami a leggyakrabban résztvevő megfigyeléssel, interjúk révén, illetve tartalom- és diskurzuselemzéssel történik" (Salter [2013], p. 52). Clifford Geertz megfogalmazása talán még pontosabban leírja, miért és hogyan válhatott az etnográfia módszerként a nemzetközi politikaelmélet tudományágának szerves részévé. Kultúrák értelmezése c. könyvében így ír: „kapcsolatokat kialakítani, informátorokat kiválasztani, szövegeket átírni, genealógiákat összeállítani, terepet bejárni, naplót vezetni, és így tovább. De nem ezek azok a dolgok, technikák és folyamatok, amik meghatározzák a tudományterületet. Ami valóban meghatározó, az a szellemi erőfeszítés, az a körülményes vállalkozás, hogy - Ryle fogalmát felhasználva - sürü leírásokat hozzunk létre” (Geertz [1973], p. 6). A sürü leírás tulajdonképpen a vizsgált emberi viselkedés vagy eseménysor társadalmi és kulturális kontextusának részletes leírását jelenti, amihez az etnográfiára jellemző tudományos empátia is hozzákapcsolódik. 
A nemzetközi kapcsolatokban etnográfiai fordulatnak és kulturalizmusnak is nevezett irányvonal kezdetei már a hagyományos racionalista elméletekhez kapcsolódva is megjelentek a hidegháború alatt, illetve az azt közvetlenül megelőző időszakban. Az etnográfiai vizsgálatok ezekben az esetekben szinte kizárólagosan az államok viselkedésére összpontosítottak a nemzetközi rendszerben, és a fegyveres konfliktusok képezték vizsgálódásaik fő fókuszát. A II. világháború idején olyan neves tudósok léptek a háborús célok szolgálatába, mint Margaret Mead vagy Ruth Benedict, segítségüket pedig információszerzésre használták fel a német és japán ellenséggel szemben. A vietnami háborúban szintén nagy szerepet játszottak az etnográfusok. A közvetlen háborús részvétel azonban nagy vitákat váltott ki, a tudományág müvelőinek nagy része a mai napig elsődleges etikai normának tartja a megfigyeltek életébe való ilyen nagymértékü és jelentős beavatkozás elkerülését (Gazdag [2011], pp. 78-80).

A kulturalizmus másik iránya a hidegháborús stratégiai realizmus ellenpontjaként jelent meg, az általános racionalista vélekedéssel szemben, miszerint az Amerikai Egyesült Államok és a Szovjetunió homogén, racionális szereplők, melyek tevékenységei és szándékai észérvek mentén egyszerủen és egyértelmüen feltárhatóak. Ekkor kezdődött meg, még mindig a hagyományos elméletek szellemében, a két szuperhatalomra jellemző katonai és szervezeti kultúrák vizsgálata, illetve társadalmi hátterük elemzése (Gazdag [2011], p. 79).

A nemzetközi kapcsolatok módszertanának meghatározó etnográfiai fordulata azonban csak a hidegháború legvégén, az 1980-as években következett be. A konstruktivizmus és a kritikai elméleti irányzatok megjelenésével a kulturális és eszmei tényezők fontos magyarázó elemként kerültek be a tudományág föáramába. A kultúra, az identitás, a normák és társadalmi struktúrák szerepének megnövekedése egybeesett a pozitivista módszerekkel való elégedetlenség növekedésével, melynek kritikái a valóságtól való végletes eltávolodást rótták fel legjelentősebb problémaként. Az „etnográfiai módszer” képes volt választ adni erre a metodológiai kihívásra, miközben kiváló eszközöket szolgáltat a kulturális tényezők feltárásához és megismeréséhez. Holisztikus szemlélete és a kontextus minél részletesebb vizsgálata révén a módszer képes arra, hogy széleskörü információkat nyújtson egy adott esettanulmány kapcsán, illetve, hogy mélyrehatóan elemezze az adott kultúrára jellemző valóságpercepciókat.

Mindezek alapján egyértelmü, hogy (a kritikai irányzatok mellett) a konstruktivizmus irányzata bizonyult a leginkább befogadónak az etnográfiai módszer irányába. Az elmélet és a módszer ugyanis azonos alapfeltételezésen nyugszik: a nyelvi és anyagi tényezők nem érthetőek meg a kontextusból kiragadott módon (Salter [2013], 
p. 56). Az etnográfiai módszer alkalmazása így a konstruktivizmus főáramúvá válása révén is egyre elterjedtebbé vált, ami a gyakorlatban háromféle módon nyilvánult meg: az adatgyüjtés módszereiben, az írások stílusában, illetve egyfajta elméleti-tudományos érzékenység kifejlődésében.

A víz az élethez való nélkülözhetetlensége révén az emberiség történelmén keresztül folyamatosan hordozott többlettartalmakat, melyek nemcsak az adott társadalmak termékei voltak, hanem kölcsönhatásban alakították, formálták is ezeket. A víz szimbolikus jelentése gyakran összekapcsolódott a szentséggel, a természettel és a kulturális örökséggel (ADB [2013], p. 4.) Közép-Ázsia társadalmainak struktúráit is nagymértékben formálta a víz, mind fizikai valójában, mind a hozzátársított többlettartalmak, többletjelentések révén. Ezen történeti hagyományok ismerete nélkül igen nehezen, illetve csak hiányosan érthető meg, hogy milyen szerepet játszanak a térség hidrológiai jellemzői, a politikai-gazdasági-társadalmi kontextus, és az ezekhez kapcsolódó diskurzusok az államközi kapcsolatok alakulásában. A megismeréshez kiváló eszközt kínál az etnográfia módszere, ami a konstruktivizmus révén kitágított módszertani keretek által a nemzetközi kapcsolatok elemzésében is egyre nagyobb szerepet kaphat - lehetővé téve így a víz szimbolikus jelentéstartalmainak megismerését, és ezáltal az államok közötti vízügyi kapcsolatok mélyebb megértését.

Az értekezés ezen fejezete a közép-ázsiai vízmegosztással összefüggő államközi kapcsolatok politikai-gazdasági-társadalmi kontextusának részletesebb feltárására vállalkozik az etnográfiai módszer alkalmazása révén, feltételezve, hogy a posztszovjet köztársaságok egy sajátos kultúrát alkotnak. Ezen kultúra vizsgálatán belül három különböző jelenség révén tárom fel a helyi alapvető normákat és identitásokat, melyek állításom szerint mind a politikai-gazdasági-társadalmi kontextus, mind a vízbiztonsági diskurzusok révén meghatározzák a vízmegosztással összefüggő államközi kapcsolatok alakulását. Ehhez először az öntözéses társadalmak jellegzetességeinek általános és specifikus vizsgálatával mutatok rá a vízigazgatás strukturáló erejére, és annak következményeire a közép-ázsiai gazdaságok esetében. A második vizsgált jelenség a szovjet civilizációs misszió és a nagyszabású vízügyi létesítmények anyagi kultúrája. A fejezet harmadik részében szintén a méreteiben jelentős vízügyi beruházásokat vizsgálom, de már az újonnan függetlenedett köztársaságok nemzetépítési törekvéseinek kontextusában. Mindezek során az adatgyüjtéshez a geertzi sürü leírás módszerét alkalmazom, főként történeti források, feljegyzések és interjúk másodlagos adatelemzése, illetve állami dokumentumok, weboldalak tartalmának vizsgálata során 
feltárva a vízkészletek fizikai jelenlétének és az ehhez társított jelentéstartalmaknak kölcsönhatását a helyi társadalmak működésével.

\subsection{A vízigazgatás mint strukturáló erő az öntözéses gazdálkodáson alapuló társadalmakban}

Karl Wittfogel [1957] klasszikus elmélete szerint az öntözéses gazdálkodás szükségletei sajátos társadalmi szerkezet kialakulásához vezetnek. Az ilyen öntözéses civilizációk esetében ugyanis a nagyszabású rendszerek kialakítása és müködtetése egy átfogó munkaszervezési struktúrát igényel, ami a központosított irányítás és a fejlett bürokratikus apparátus létrejöttéhez vezet. A megerősödő politikai kontroll azonban az említett szerzők szerint igen gyakran egy autoriterré vagy despotikussá váló államban ölt testet, ami strukturális vagy közvetlen erőszak révén irányítja a gazdaságot és a társadalmat. Az öntözéses civilizációk tehát ezen elmélet alapján önmagukban hordozzák mind a magas szinten szervezett, hierarchikus társadalmak kialakulását, mind a konfliktusra való potenciált.

Bár a determinisztikus és inherens konfliktus gondolatát a későbbi szerzők számos müben cáfolták, egyértelmü, hogy az öntözéses gazdálkodás valóban jelentős hatást gyakorol a társadalmi szerkezet alakulására, ami visszaható módon szintén formálja az öntözéses gazdálkodás módszereit és folyamatát (Hill [2000]). KözépÁzsiában is egy igen sajátos társadalomszerkezet alakult ki az Aral-tó vízgyüjtőjének öntözésre alkalmas területein. A térségben ugyanis nem alakult ki a földmagántulajdon, az állami földtulajdonlás és az ahhoz kapcsolódó használati jog feletti rendelkezés pedig nagymértékben meghatározta az állam és a közösségek viszonyát. Ugyanez igaz volt a vízkészletek tekintetében is: a vízkészletek hagyományos tulajdonosa az állam volt, a közösségek csak használati jogot nyerhettek felette (Katona [1997], p. 603). Ez a jellegzetesség évezredeken keresztül formálta a térség lakosságának viszonyát a vízügyi kérdésekkel kapcsolatban, hatása napjainkban is meghatározza az ezekhez való hozzáállást.

Középkori arab geográfusok, mint például Ibn Hawqal leírásaiból tudjuk, hogy az öntözéses gazdálkodás már az iszlám megjelenése előtt jelentős volt Közép-Ázsia területén (de la Vaissiére [2005], Hill [2000]). Az egyik jelentős feltárt tárgyi bizonyíték

a közép-ázsiai öntözéses civilizációk fejlettségére egy, a VI-VII. század körül épült gát Üzbegisztánban, ami egyértelműen bemutatja a korabeli vízgazdálkodás magas színvonalát, mind a geológiai ismeretek, mind a mérnöki tudományok terén. A gát 
hossza $85 \mathrm{~m}$, szélessége 15,3 m volt, magassága pedig 9,5-14,5 m közé tehető, víztározója segítségével 1 000-1 200 hektárnyi földterületet öntözhettek (AbdullaevRakhmatullaev [2013], p. 3). Szintén erről tanúskodik a csigir elnevezésű, vízkiemelésre használt eszköz (és annak különböző elnevezésű változatai) ami a középkorban jelent meg a térségben (GWP CACENA [2011], p. 7). A vízikerékre emlékeztető eszköz használata a jelenkor mérnökei szerint is a leginkább megfelelő módszer volt, ami tökéletesen alkalmazkodott a térség viszonyaihoz. Elterjedésével a terméshozam a kétszeresére nőtt (Hill [2000], p. 294). Az 1930-as években több mint hatezer csigir müködött az Amu-darja alsó folyásánál, némelyikük még ma is használatban van (GWP CACENA [2011], p. 13).

A vízigazgatási rendszerek folyamatosan fejlődtek az egyszerü árasztásos módszerektől a modern öntözés technikái felé, és egyre nagyobb területeket vontak uralmuk alá. A XIX. századra kialakult öntözési módszerekről és az azokhoz kapcsolódó társadalmi jellegzetességekről több korabeli leírás maradt fenn, melyek közül az egyik legrészletesebb Alexander Theodor von Middendorf 1882-es müve, melyben a kokandi kánság öntözési rendszeréről tudósít nem sokkal az orosz hódítás után. Az ekkori fergana-völgybeli társadalomszerkezet és a vízigazgatásban betöltött szerepek, illetve azoknak az iszlámmal való összefonódásai még jól tükrözik az évezredek során kifejlődött közép-ázsiai öntözéses társadalmak jellegzetességeit. A vízkészletek felett isteni elrendelés révén a kán maga rendelkezett, az ő feladata volt a vízkészletekhez kapcsolódó jogok biztosítása és a kötelezettségek kirovása. A legjelentősebb vízügyekhez kapcsolódó tisztség a miráb basi volt, aki közvetlen felelősséget vállalt a vízkészletek kezeléséért és megosztásáért. A miráb basit az uralkodó nevezte ki, és különleges jogokkal és kötelezettségekkel ruházta fel (GWP CACENA [2011], p. 11).

A vízigazgatás következő szintjén a helyi mirábok álltak, akiket a helyi közösségek dehkanjai, vagyis a földmüvelők és vízfelhasználók választották és fizették bérét. Mindezek révén nagymértékben tudták befolyásolni a mirábok viselkedését, hiszen jövedelmét annak alapján jelölték meg, hogy mennyire voltak elégedettek munkájával. A miráb a nagyobb helyi csatornák igazgatását végezte, melynek kisebb leágazásaiért az ariq amin-ok (ariq: alacsonyabbrendủ csatorna) voltak felelősek. A miráb és az ariq amin feladata volt, hogy az éppen aktuális vízállást számításba véve zsilipek segítségével szabályozza a vízmennyiséget. A tisztségviselők szigorúan és rendkívül fegyelmezetten irányították a vízkészletek megosztását, ami megelőzte a túlöntözést, a talaj túlnedvesedését, és a vízkészletek pazarlását. A vízigazgatás 
rendszerébe tagozódtak a ketmanok is, amelyek három-négy faluból álló közösségeket jelentettek. A ketmanok annak érdekében jöttek létre, hogy biztosítsák a csatornarendszer építési és karbantartási munkálatainak hátterét. Ezeket a munkálatokat a miráb basi és a mirábok szervezték meg, közmunkára hívva a ketmanok lakóit. A ketman vízügyeinek mindennapi intézésére és a miráb tevékenységének felügyeletére a falvak ariq akszakalt („fehér szakállút”), vagyis választott elöljárót jelöltek ki. A végleges döntések a közösség falvai által küldött ariq akszakalok megbeszélése révén alakultak ki. A vízigazgatás legkisebb egysége a top volt, ami néhány utcát vagy családot jelentett egy adott ketmanon belül.

Bár a nagyszabású munkálatokat, mint egy új csatorna építése, a közösség egésze végezte, mindenki kötelezően felelős volt az általa használt csatornák tisztításáért, karbantartásáért. Ennek elmaradása az egész ketman rosszallását kivívta, és magas büntetés kirovásához vagy a használt földterület és vízkészlet elvesztéséhez vezethetett. A népesség számára tehát természetes volt, hogy a vízkészletek (és a földterületek) a kán tulajdonát képezik, ők maguk csak használói a közösség által rendelkezésükre bocsátott erőforrásoknak, melyekböl a család nagysága alapján részesültek. Az öntözőrendszer fenntartásáért végzett közösségi munka (hasar) példája és annak szankciói jól mutatják a közösségi vízfelhasználás rendszerének müködését, illetve a lakosság ahhoz kapcsolódó felfogását (O’Hara [2003], pp. 18-21, AbdullaevRahkmatullaev [2013], p. 4).

Az orosz hódítás kezdetben nem eredményezett nagy változásokat a vízigazgatás rendszerében, ahogyan az élet legtöbb más területén sem. A kialakult bürokratikus rendszer gyakorlatilag megmaradt, csupán kiegészült a cári rendszer legfelsőbb szintü fennhatóságával. Az orosz birodalmi apparátus túlságosan veszélyesnek látta volna a beavatkozást a társadalom szerkezetében is fontos szerepet játszó, évszázados történetre visszatekintő vízügyi bürokrácia működésébe, melyet igen kevéssé ismert és látott át. Így, annak ellenére, hogy a meghódított területek cári igazgatásának irányítói érzékelték és szóvá is tették a modernizáció szükségességét, a helyi struktúrák a hagyományos módon folytathatták a vízigazgatási rendszer müködtetését, és az ehhez kapcsolódó társadalmi normák, identitások is fennmaradhattak (GWP CACENA [2011], p. 13).

A cári Oroszország 1895 és 1915 között 37 millió rubelt (1970-es árfolyamon számítva) fektetett be az öntözéses gazdálkodásba, ami nem tekinthető számottevő összegnek. Ebben az időszakban 80000 hektárnyi földterületet műveltek meg öntözés segítségével. Bár az öntözött földterületek kiterjedése nőtt, illetve megindult a vízgyüjtő területek és öntözőrendszerek feltérképezése, adminisztratív nyilvántartásba vétele 
(Abdullaev-Rahmatullaev [2013], pp. 7-8), a vízgazdálkodás terén történt kismértékü változások nem gyakoroltak jelentős hatást a társadalom szövetére, a vízmegosztással összefüggő diskurzusokra, identitásokra. A XX. század elején a vízkészletek kezelése továbbra is közösségi szinten zajlott (míg a földtulajdon-rendszerben egyre több magántulajdon-szerü elem jelent meg, ld. Katona [1997], pp. 604-605).

A tradicionális mezőgazdasági termelési viszonyok tulajdonképpen 1929-ig érintetlenek maradtak (Katona [1997], p. 601). A NEP és a tervgazdálkodás bevezetése, majd a kollektivizálás, illetve az ezeket övező anomáliák hatására azonban megkezdődött a hagyományos öntözéses kultúrára épülő társadalomszerkezet bomlása. A földmagántulajdon tradicionális hiánya és a vízkészletek közösségi kezelésének gyakorlata azonban ebben az esetben leegyszerüsítette az átalakítást, a társadalom számára nem jelentett radikális újdonságot a kollektivizálás gyakorlata. Az 1920-as években a szovjet központi hatalom úgy vélekedett, hogy a vízigazgatás hagyományos viszonyai elősegítik a kollektivizálás folyamatát, és ennek következtében nagyobb jelentőséget tulajdonított a vízügyi reformoknak, mint a földtulajdon rendezésének. Az 1930-as években azonban gyökeres fordulatot vettek az események, Moszkva célja a tradicionális közösségek teljes szétdarabolása, új egységekbe való tömörítése lett. Megindult az öntözési rendszerek átalakítása, ekkor indult fejlődésnek a gyapotmonokultúra rendszere Közép-Ázsiában, és ekkor készültek el az első nagyszabású öntözési tervek, melyek révén újabb és újabb területeket vontak be a termelésbe (Katona [1997], p. 608). Ironikus módon a hagyományos öntözéses társadalmi viszonyok még itt is hozzájárultak a társadalom elfogadásának elösegítéséhez. A központi irányítással zajló gigantikus közmunkákat párhuzamba lehetett állítani a tradicionális hasar rendszerével, a vízkészletek tulajdona a kánhoz hasonló módon a szovjet államot illette, az átfogó stratégiai tervezésbe a lakosság sosem szólhatott bele. Feladatai így nagyban megegyeztek a korábbiakkal, vagyis saját csatornaszakaszaik rendben tartása és a hasar közmunka mellett más teendőjük tulajdonképpen nem volt. A hagyományos vízügyi bürokrácia tisztségei megszüntek ugyan, de az irányítás és eszközei csak még erőteljesebbé váltak a szovjet hatalom idején.

Mindezt összefoglalva látható tehát, hogy Közép-Ázsiában egy több évszázados hagyományos gazdálkodási móddal állunk szemben, amire az évszázadok során egy bonyolult, az élet minden területét átfogó hatalmi gyakorlat és társadalmi szerkezet épült. A politikai-gazdasági-társadalmi kontextus ismeretében világossá válik, hogy az ezekből fakadó strukturális kényszerek a lakosság percepciójában elkerülhetetlenné 
teszik az öntözéses gazdálkodás és az ebbe beágyazódott hagyományos hatalmi és társadalmi jellegzetességek folytonosságának fenntartását. A rendszer fenntartásához pedig vízre van szükség, melynek biztosítása a központi hatalom feladata. Ez a struktúra, bár a XX. század során számos változáson ment keresztül, a mai napig a közép-ázsiai köztársaságok egyik legfontosabb pillérét képezi, megértése pedig nélkülözhetetlen a térség viszonyainak feltárásához, elemzéséhez.

A következőkben azt tekintem át, hogy a XX. század két fontos fordulópontja, a szovjet uralom kezdete, majd a függetlenség kikiáltása hogyan alakította át a vízigazgatási struktúra egyes elemeit, új jelentéstartalommal kiegészítve azokat, új identitásokat és normákat teremtve, másokat pedig háttérbe szorítva. Eközben azonban folyamatosan hangsúlyozom, hogy az évszázadok alatt kialakult rendszerek magja, a vízügyi igazgatás és az azt irányító központi hatalom társadalmi szerepe alapvetően változatlan maradt.

\subsection{Nagyméretű gátrendszerek a Szovjetunióban: Modernizáció és szovjetesítés}

Az intelligencia, a zsenialitás, a fejlettség, a civilizáció és a haladás fogalmai már a XIX. század során világszerte összekapcsolódtak a nagyszabású modern vízügyi rendszerek kiépítésével. A természet feletti uralom, a vad erők megszelídítése, betörése, a sivatagok termővé változtatása az egész emberiség előtt álló feladatként, kihívásként jelent meg az elterjedt diskurzusokban (Molle et al. [2009], p. 330). A Szovjetunió osztozott azokban a nézetekben, amik a gazdasági és társadalmi problémákra a technológia civilizáló erejében látták a választ, és a racionalitást tekintették a „civilizációs misszió” alapkövének. A szabadság, a munka teremtő ereje és a természet feletti uralom fogalmai már az 1930-as években összefonódtak (Josephson [1995]), az 1948-ban Sztálin által megindított „Terv a természet átalakítására” (Molle et al. [2009], p. 334) pedig világosan mutatja a diskurzus fontosságát. Hruscsov 1953-as programja a „szüzföldek feltörésére” szintén nagyszabású természet-átalakítást jelentett, ami egyértelműen érintette Közép-Ázsia vízügyi rendszereit.

A szovjet időszakban az öntözéses gazdálkodás és a hozzákapcsolódó energiatermelés fontossága már korán megjelent Közép-Ázsia kapcsán is - ennek elméleti jelentőségét jól mutatja, hogy Lenin 1918-ban 50 millió akkori rubel elkülönítéséről rendelkezett a közép-ázsiai öntözési rendszerek fejlesztésére. (Az ambiciózus terv forráshiány miatt nem valósult meg, a közép-ázsiai öntözőrendszerek támogatására az 1920-as években csak 7 millió rubel jutott. Az, hogy az 1980-as 
évtizedben az öntözésre fordított befektetések értéke meghaladta az 1743 millió rubelt, egyértelmüen azt mutatja, hogy a szovjet rendszer számára a későbbiekben a gyakorlatban is kiemelt fontosságúvá vált a közép-ázsiai öntözéses gazdálkodás fejlesztése (Abdullaev-Rahmatullaev [2013], p. 8)).

A tradicionális mezőgazdasági termelési viszonyok azonban tulajdonképpen 1929-ig érintetlenek maradtak (Katona [1997], p. 601). A NEP és a tervgazdálkodás bevezetése, majd a kollektivizálás, illetve az ezeket övező anomáliák hatására kezdődött meg a hagyományos öntözéses kultúrára épülő társadalomszerkezet bomlása. A földmagántulajdon tradicionális hiánya és a vízkészletek közösségi kezelésének gyakorlata azonban ebben az esetben leegyszerüsítette az átalakítást, a társadalom számára nem jelentett radikális újdonságot a kollektivizálás gyakorlata. Az 1920-as években a szovjet központi hatalom úgy vélekedett, hogy a vízigazgatás hagyományos viszonyai elősegítik a kollektivizálás folyamatát, és ennek következtében nagyobb jelentőséget tulajdonított az ezeket még számításba vevő korai vízügyi reformoknak, mint a földtulajdon rendezésének (Katona [1997], p. 608).

Az 1930-as években gyökeres fordulatot vettek az események, Moszkva célja a tradicionális közösségek teljes szétdarabolása, új egységekbe való tömörítése lett. Megindult az öntözési rendszerek átalakítása, ekkor indult fejlődésnek a gyapotmonokultúra rendszere Közép-Ázsiában, és ekkor készültek el az első nagyszabású tervek, melyek révén újabb és újabb területeket vontak be a termelésbe (Katona [1997], p. 608). Ironikus módon a hagyományos öntözéses társadalmi viszonyok még ebben az időszakban is hozzájárultak a társadalom elfogadásának elősegítéséhez. A központi irányítással zajló gigantikus közmunkákat párhuzamba lehetett állítani a tradicionális hasar rendszerével, a vízkészletek tulajdona a kánhoz hasonló módon a szovjet államot illette, az átfogó stratégiai tervezés folyamatában a lakosság pedig korábban sem vett részt. Feladatai így nagyban megegyeztek a korábbiakkal, vagyis saját csatornaszakaszaik rendben tartása és a közmunka mellett más teendőjük tulajdonképpen nem volt. A hagyományos vízügyi bürokrácia tisztségei megszüntek ugyan, de az irányítás és eszközei csak még erőteljesebbé váltak a szovjet hatalom idején. A kollektivizáció és a nacionalizáció alapvető folyamatainak lezajlása után egyre nagyobb figyelem irányult Közép-Ázsia gazdaságának össz-szovjet érdekekkel való összehangolására, a térség specifikumainak minél hatékonyabb kihasználására.

Az öntözés jelentősége az 1940-es évektől nagymértékben megnövekedett, nagyszabású központi rendszerek jöttek létre a feladatok ellátására, a 
csatornarendszerek hálózatai gyors ütemben terjeszkedtek. A munkálatok sokszor szinte hihetetlennek tünő gyorsaságát jól szemlélteti a Nagy Ferganai Csatorna kiépítése, mely 1939-ben indult meg 160000 üzbég kolhozmunkás részvételével. A 270 km hosszúságú csatorna kevesebb, mint 45 nap alatt készült el (Seventeen Moments). A kiterjedt öntözőrendszerek nagy része a vízigényes gyapot termesztését volt hivatott elősegíteni. Az Amerikai Egyesült Államokkal folytatott világméretű versengés fontos eleme volt ezen növény termesztése és értékesítése a világpiacon. A Szovjetunió számára fontos gazdasági célkitüzés volt az önellátás elérése a gyapotellátás terén, mely jelentős világgazdasági függéseket szüntetett meg. A világpiacra termelt készletek pedig a kemény valuta jelentős forrásai voltak. Közép-Ázsia gazdasága alárendelődött a gyapottermesztés monokultúrájának, a korábbi egyéni gazdaságokat kiterjedt állami gazdaságok váltották fel. A Szovjetunióban előállított gyapot 2/3-át Üzbegisztán adta (Kandiyoti [2007], p. 1). A gyapottermesztés mellett a nagyszabású vízügyi projektek kivitelezésének fokozott üteme is az amerikai-orosz hidegháborús versengés része volt, hiszen ezek a politikai-gazdasági rendszerek magasabbrendűségét tükrözték (Molle et al. [2009], p. 335). Az újonnan kiépített gátrendszerek a hozzájuk csatlakozó vízerőmüvek révén emellett energiatermelési célokat is szolgáltak.

A nagyméretü gátrendszerek kiépítése általánosságban véve, a Szovjetunió kontextusától eltekintve is szorosan összekapcsolódik a természeti erőforrások feletti abszolút hatalom gyakorlásával, különösen annak révén, hogy időben és térben módosítja azok eloszlását és birtoklását (Féaux de la Croix [2010], p. 6). Az öntözőrendszerek és vízerőmüvek kiépítése látványosan megváltoztatja a környezeti viszonyokat, számos embert mozgósít, és képes arra, hogy békés módon, a fejlesztés, a „civilizációs misszió” keretei között demonstrálja az állam hatalmát, kiterjesztve annak mikrostruktúráit a társadalom körében (Féaux de la Croix-Suyarkulova [2015], p. 104). A munkálatok emellett, békés és építő jellegük ellenére, háborús veszélyhez hasonló mozgósító erőt testesítenek meg, a munkálatok fizikai erőt, önfeláldozást igényelnek, és a pátosznak, a hősiességnek is teret adnak (Bromber et al. [2014], p. 293). Mindez különösen igaz a Szovjetunió kontextusában, ahol a homo sovieticus megteremtése szempontjából ezek a tulajdonságok igen nagy szereppel bírtak.

A Szovjetunió esetében a nagyméretű gátrendszerek kiépítéséhez általánosságban kapcsolódó tartalmak kiegészülnek a lakosság, különösen a munkásság erejének egyesítésével a fejlődést szolgáló közös célok megvalósítása érdekében. A nép büszkesége, valamint a munka kultusza, az erőfeszítés értéke igen nagy szerepet kapott ezekben a diskurzusokban. A kirgiz Narin folyón épült Toktogul gát falán például az 
átadás után hosszú ideig látható volt a „Narin, szolgáld a népet!” („Narin, szluzsi narodu!”) felirat, ami röviden és velősen foglalta össze ezeket a jelentéstartalmakat (Féaux de la Croix [2010], pp. 6-7). A gáthoz csatlakozó vízerőmü belsejében pedig a következő Lenin-idézet erősítette meg a Toktogul szimbolikus jelentőségét: „A kommunizmus a szovjet hatalom és az egész állam villamosítása” („Kommunizm - eto szovjetszkaja vlaszty pljusz elektrifikacija vszej sztrani”) (Féaux de la Croix [2011], p. 495).

Az Új Szó 1956. február 1-jei számában „A Volga leigázása” címmel megjelenő cikk magyar nyelven is jól tükrözi a vízügyi infrastruktúra fejlesztéséhez társuló jelentéstartalmakat, mind a munka és az együttmüködés értékét, mind a létesítményeket övező pátoszt: „Az egész ország segítette és segíti a kujbisevieket: emberekkel, gépekkel, szakértői tanácsokkal. Az egész ország építette és építi a kujbisevi vízierőmüóriást. S 1955 végén a vízerőmü építői így üdvözölték az országot: - Boldog új évet! Új árammal köszöntjük hazánkat!’” (Új Szó [1956], p. 4) A munka, az erőfeszítés fontosságát hangsúlyozták a nagy számban megjelenő tudósítások azokról a munkásokról, akik valamilyen tekintetben kitüntek az építkezések során (Féaux de la Croix-Suyarkulova [2015], p. 112). Emellett az internacionalizmus és a népek közötti barátság és együttmúködés gondolata is hangsúlyozottan megjelent a munkálatok során (Féaux de la Croix [2014], p. 94) - nem véletlen, hogy magyar nyelven is fontos hírnek számított a kujbisevi vízerőmű átadása.

Közép-Ázsia szovjet köztársaságaiban az épülő gátak, vízerőművek és öntözőrendszerek a jólét, a modernitás és a társadalmi igazságosság jelképeiként számos ígéretet és reményt is megtestesítettek, a biztosított energia- és élelmiszerellátástól egészen a modern polgár és az „új”, esetünkben szocialista társadalom kialakulásának képéig (Bromber et al. [2014], p. 290). A szovjet fennhatóság szimbolikus és gyakorlati gazdasági megerősítése mellett a nagyméretű gátrendszerek létrehozása az új államok és nemzetek építését, az állami és nemzeti közösségi kohézió megteremtését is szolgálta. Ebben nagy szerepet játszott a kulturális élet fejlesztése is, melynek fontos célja volt, hogy átvitt értelemben is ,kiemelje a dolgozó tömegeket a sötétségből, és elvezesse a kultúra és az emberhez méltó élet birodalmába" (Bayalieva-Talitskii [1979], idézi Féaux de la Croix [2014], p. 94). A Toktogul víztározó építése során létrehozott ugyanilyen nevü városban például 600 férőhelyes kultúrház és 300000 könyvvel rendelkező könyvtár épült (Féaux de la Croix [2014], p. 94).

Közép-Ázsiában emellett a muszlim alapokra épülő és a helyi hagyományokban jelenlévő szimbolikus jelentéstartalmak is hozzájárulnak a gátak jelentőségéhez, hiszen 
ezek a tisztaság, a növekedés, a gyógyulás és az élet forrását jelképező vizek feletti hatalom gyakorlását jelentik, és ebben a formában nagy jelentőséggel bírnak (Féaux de la Croix [2011], p. 490). Mindemellett arról sem szabad megfeledkezni, hogy a szovjet „civilizációs misszió” modernizációs törekvéseinek megvalósulása elképzelhetetlen volt a hagyományos közép-ázsiai társadalmi kötelékek megbontása nélkül. A vízigazgatási paradigmák átalakulása jelentős hatást gyakorolt a társadalmi, gazdasági, politikai és technológiai struktúrákra (Abdullaev-Rahmatullaev [2015], p. 2). Az, hogy ez számos pozitív hatással járt például az oktatás, az egészségügy, a tudományos élet és a kultúra területén, nem jelentette azt, hogy a társadalom nyitottan viszonyult volna a hagyományos szerkezetét és müködését is érintő változásokhoz. A vallás és a nők helyzete két tipikusan nagy ellenállást kiváltó kérdés volt az 1920-as és 1930-as években.

A nagyméretű gátrendszerek kiépítése egyrészt fizikai valójában, másrészt pedig a modernizáció szimbólumaként is részét képezte a szovjet „civilizációs misszió” és a hagyományos közép-ázsiai társadalmi identitások és normák küzdelmének. A kitelepítések és az elárasztott területeken található történelmi, vallási és családi relikviák elpusztítása egyértelműen hozzájárult a hagyományos társadalmi kötelékek megbontásához. A Toktogul gát építésénél például 35000 embernek kellett elhagynia lakóhelyét (Féaux de la Croix [2010], p. 6.). A családok, ősök csontjait rejtő temetők és a szentnek tekintett zarándokhelyek, mazarok elárasztása különösen nagy problémát jelentett a helyi lakosság számára, mind a hagyományok, mind a vallás szempontjából (Féaux de la Croix-Suyarkulova [2015], p. 112; Sodiqov [2013], p. 55). Mindezek miatt a kitelepítés kérdése került először előtérbe, amikor a peresztrojka időszakában egyre inkább felszínre törtek a kritikák a nagyszabású gátrendszerek kiépítésével kapcsolatban, illetve amikor, szintén ugyanebben az időszakban, egyre határozottabb ellenállás alakult ki a Rogun gát építésével szemben (Mirzorahmatov [2011]). Kirgizisztánban hasonló, bár kevésbé intenzív folyamatok indultak meg, szintén az elárasztott területek révén elvesztett identitás-elemekre összpontosítva (Féaux de la Croix-Suyarkulova [2015], p. 120). (Érdekes megfigyelni azt is, hogy a számottevő és látványos környezeti károk helyett sokkal inkább az identitás-elemek kerültek első helyre a veszteségek között a helyi lakosság számára.)

A nagyszabású építkezések a vizekkel kapcsolatos hagyományos diskurzusokat, szimbólumokat is igyekeztek megváltoztatni. A gátak Féaux de la Croix szerint „karizmával bíró tárgyaknak tekinthetőek” (Féaux de la Croix [2010], p. 6), melyek lenyügöző látványukkal a technológia kvázi-megszenteltségét közvetítik. Ez különösen 
fontossá vált az ateizmust hirdető Szovjetunióban, ahol a korábbi hagyományos muszlim diskurzusok helyett a munka és a szovjet hatalom ,szentsége” került a középpontba. A gátrendszerek hatalmas méretei, illetve az építkezések hatására átalakított környezet emellett a modernitás és a szovjet hatalom elkerülhetetlenségét, véglegességét és visszafordíthatatlanságát is szimbolizálta, illetve azt sugallta, hogy ezek ellen felesleges lenne bármilyen társadalmi vagy politikai fellépés (Bromber et al. [2014], p. 294-295).

Tény, hogy a nagyszabású vízügyi projektek nagymértékben hozzájárultak a társadalom jólétéhez, ellátásbiztonságához és az árvízvédelemhez, illetve szélesebben értelmezve a közép-ázsiai államok fejlődéséhez, azonban sok olyan eset is előfordult, amikor a hatalmas létesítmények kiépülése öncélúvá vált, hangsúlyozva a központi hatalom erejét. Számos esetben minden körülményt ennek rendeltek alá, nem törődve az esetleges negatív környezeti, gazdasági és társadalmi hatásokkal (Molle et al. [2009], p. 328). Végül azt is meg kell említeni, hogy a Szovjetunió időszakában zajló építkezések alapvetően szovjet projektek voltak, és a központi hatalom által meghatározott célokat szolgáltak, mind fizikai megvalósulásukban, mind szimbolikus értékük révén.

Minden változás ellenére azonban megmaradt a szoros összekapcsolódás a vízügyi infrastruktúra, vagyis az öntözéses gazdálkodás és a társadalom struktúrája, normái, identitása között, illetve a központi hatalom szerepe, felelőssége mindennek irányításában és alakításában.

\subsection{Nagyméretü gátrendszerek az újonnan függetlenedett köztársaságokban: $\mathrm{Az}$ állam- és nemzetépítés eszközei}

A gátak, vízierőművek, öntözőrendszerek társadalmi jelentőségét övező diskurzus a dekolonizáció kezdetével nagymértékben átalakult. Az akkori harmadik világ újonnan függetlenedő országai számára ezek az önállóság, a modernitás és a fejlődés szimbólumaivá váltak, amivel demonstrálni tudták, hogy képesek felvenni a versenyt, és a gyarmatosító hatalmak nélkül is megállják helyüket a nemzetközi gazdasági rendszerben.

A gyarmatosító hatalmak vízügyekkel kapcsolatos politikai, bürokratikus és tudományos elitjeinek távozása után a függetlenségüket újonnan elnyert államok számára igen jelentős feladattá vált saját elitjüknek, saját vízigazgatási rendszerüknek létrehozása. „A nagyméretű gátak nemcsak az öntözéshez és a hatalmi rendszerek kialakításához kínálnak lehetőséget, hanem a nemzetállamok építéséhez is" - írja 
Mitchell ([2002], p. 44). Mohira Suyarkulova szerint a nagyméretü gátak megépítése egyenesen egy rítusnak tekinthető, aminek révén az adott állam bekerülhet a teljes szuverenitást gyakorolni képes, „felnőtt” államok körébe (Suyarkulova [2014], p. 369).

Bár Közép-Ázsia köztársaságai nem tekinthetőek a hagyományos értelmezés szerinti posztkoloniális államoknak, a gyakorlatban sok tekintetben emlékeztetnek azokra, különösen a függetlenség elnyerése utáni kihívások szempontjából. KözépÁzsiában ugyanis, hasonlóan számos posztkoloniális államhoz, sosem létezett nyugati típusú államiság. A Szovjetunió időszakában az állam- és nemzetépítés folyamata korlátozottan, a központi hatalom érdekeinek megfelelően zajlott. Annak ellenére, hogy az alkotmányos rend garantálta a modern államokra jellemző intézményrendszer kialakulását a köztársaságokban, azok valós tartalommal történő feltöltése a függetlenség elnyeréséig nem valósulhatott meg.

A Szovjetunió felbomlása után az új politikai, gazdasági és társadalmi kihívásokra válaszul nagy szükség volt az újonnan megválasztott kormányzatok legitimációjának megerősítésére, az állam hatalmának demonstrálására, illetve az új államok határain belül élő népek valós, szorosabb közösségének megteremtésére. Az utóbbi különösen annak fényében jelentős, hogy a közép-ázsiai államokban alapvetően jellemző a különböző politikai érdekcsoportok harca, melyeket egyértelmüen meghatároznak a törzsi-nemzetségi gyökerek, illetve az általuk hagyományosan birtokolt területek. Mindezek hatására az állam- és nemzetépítés folyamatainak szerepe jelentősen megnövekedett, miközben a korábban ezekre irányuló szovjet mechanizmusok (melyek egy más típusú állam- és nemzetépítés eszközei voltak) gyorsan a háttérbe szorultak.

A politikai-gazdasági-társadalmi kontextus megváltozása a vízigazgatási paradigmákban és az azokhoz társított szimbolikus jelentéstartalmakban is megjelent melyek alig hetven éven belül másodszor is jelentős átalakulásnak indultak a térségben. A hagyományos posztkoloniális államokkal szemben Közép-Ázsia egy müködő vízigazgatási rendszert örökölt a Szovjetuniótól. Ez a rendszer azonban a régió egységére épült, az egyes köztársaságok önállósulása és nemzeti érdekeik elötérbe kerülése a közös vízigazgatási rendszer feldarabolásához és megszüntetéséhez vezetett. A csökkenő energiatermelés és gyapottermelés hatására komoly társadalmi feszültségek bontakoztak ki. Az áramellátás hiányosságai és a magas árak hozzájárultak a tádzsik polgárháború kitöréséhez 1992-ben (Sodiqov [2013]), illetve fontos szerepet játszottak a 2005-ben és 2010-ben kirobbant kirgiz forradalmak során is (Wooden [2014]). Kirgizisztán esetében sokatmondó, hogy a nagyszabású gátépítés a forradalmi 
kormányváltásoktól függetlenül halad tovább. A Kambar-ata II. vízerőmü 2010-ben, a kirgiz függetlenség napján lezajlott átadási ünnepsége is egyértelmüen magán hordozta a nemzet- és államépítés jellegzetességeit.

Mindezek alapján egyértelmü, hogy a víz- és energiaellátás biztosítása, illetve az ezek biztonságát garantálni képes vízigazgatási rendszerek megfelelő müködtetése szorosan összekapcsolódik a kormányzat legitimációjának és a társadalom kohéziójának növelésével, vagyis az állam- és nemzetépítés folyamatával. A gátrendszerek építése és újjáépítése, különösen Kirgizisztánban és Tádzsikisztánban, ezen folyamatok alakításának fontos eszközévé vált. A természet felett uralkodó ember szimbóluma és a munka kultusza a háttérbe szorult, miközben sokkal inkább előtérbe került a közösség, a nemzet, az állam, illetve a függetlenség, az önálló erő, a regionális vezető szerepre törekvés hangsúlyozása. Az állami hatalmat demonstráló impozáns épületek, szobrok, új városok mellett a nagyméretü gátrendszerek is presztízstárgyakként szolgálták a kormányzat érdekeit, látványukkal erősítve a nemzeti büszkeség érzését a társadalom tagjaiban (Bromber et al. [2014], p. 290).

A nagyszabású vízügyi létesítmények, mint a kirgizisztáni Kambar-ata I., vagy a tádzsikisztáni Rogun gát, a szovjet időszak után tehát új jelentéstartalmat kaptak, ami egyértelmúen a nemzet- és államépítéshez, a közös nemzeti értékekhez, a nemzetiállami egységhez kapcsolódik. Mindez határozottan megjelenik az állami retorikában. Tádzsikisztán elnöke, Emomali Rahmon több beszéde is kiválóan tükrözi a gátrendszerekhez társított új jelentéstartalmakat, amint azt a következő idézetek is mutatják: „Rogun a mindenünk: a hitünk, a jövőnk, az egységünk” (Féaux de la CroixSuyarkulova [2015], p. 115). „Rogun nemcsak a fény forrása, hanem a nemzeti becsületé és büszkeségé is.” (UPI [2010]). Az állam- és nemzetépítés retorikája a mindennapi kulturális életben is megjelenik, aminek egyik szélsőséges példája a népszerü énekes, Afzalshoh Sodiev Rogun gátról szóló dala (Youtube [2010]).

A szentség gondolata is visszatér, szintén új tartalommal kiegészülve, az építkezések a nemzeti együttmüködés révén nyerik el kvázi-szakrális tartalmukat. Tádzsikisztánban a hazafiasság mellett a ,jó muszlim” kategória is összekapcsolódik az építkezések támogatásával (Suyarkulova [2014], p. 375). A vízkészletek jogi státuszának felfogásában is visszatér a szakralitás gondolata: a vízkészleteket Isten ajándékának tekintik. A felvízi államok felfogásában ez az isteni ajándék csak az adott nemzetet illeti meg, értékét más felhasználóinak, így az alvízi államoknak meg kell fizetni. Ez elvben megerősíti Kirgizisztán és Tádzsikisztán szuverenitását a vízkészletek felett. (Az alvízi Üzbegisztán retorikája szintén felhasználja az isteni ajándék kifejezést, 
de éppen az ellenkező értelemben, amellett érvelve, hogy ez az ajándék egész KözépÁzsiát megilleti, a felvízi országok nem sajátíthatják ki a vízkészleteket.) (Suyarkulova [2014], pp. 379-381).

A határokon átnyúló folyók esetében a nagyméretü gátrendszerek építésénél és üzemeltetésénél megkerülhetetlen az államok közötti vízmegosztás kérdése. Az újonnan függetlenedett közép-ázsiai köztársaságok számára a kormányzat hatalmát demonstráló szimbolikus erővel bír a vízkészletek feletti szuverenitás megőrzése, ami különösen felvízi és alvízi államok viszonyaiban merül fel. A felvízi államok egyértelmű stratégiai előnye mellett Kirgizisztán és Tádzsikisztán további belpolitikai előnyt is igyekszik szerezni, méghozzá az alvízi Üzbegisztán ellenségképének hangsúlyozása révén. A vízmegosztással kapcsolatos ellenséges hangvételü állami retorikája olyan rivális és elnyomó hatalommá teszi Üzbegisztánt a felvízi államok szemében, mely megerősíti a kirgiz és a tádzsik lakosság közösségét, ezzel hozzájárulva az állam- és nemzetépítés folyamataihoz (Wooden [2014], p. 464, Suyarkulova [2014], p. 372).

Az állam- és nemzetépítés folyamatai azonban nem zajlanak problémamentesen, és ennek forrásai a gátrendszerek kapcsán is megfigyelhetőek. Ilyen ok például a munka, az erőfeszítés szerepének háttérbe szorulása, ami elidegeníti az embereket a nagyszabású vízügyi munkálatoktól. Ehhez az is hozzájárul, hogy, bár az állam és az érintett vállalatok munkát ígérnek az építkezések környékén élőknek, ehelyett egyrészt magas képzettségü szakembereket keresnek, másrészt pedig gyakran távolabbról utaztatják a térségbe az olcsóbb munkaerőt, ami komoly feszültségekhez vezet (Féaux de la Croix-Suyarkulova [2015], pp. 116, 123).

A nagyszabású közmunkák megszüntek ugyan, de a közösségi részvétel gondolata (bár sokkal vitatottabb formában) fennmaradt. A társadalom tagjainak ugyanis, mind Kirgizisztánban, mind Tádzsikisztánban jelentős anyagi hozzájárulással kell támogatniuk a munkálatokat. A tádzsik lakosság számára hazafias kötelezettség részt vállalni a Rogun gátrendszer építésében, melynek garantálásáról (gyakran kikényszerítéséről) az állami bürokrácia gondoskodik (Suyarkulova [2014], pp. 375376). „Abból, ahogyan megfogalmazták [a rendelkezést], egyértelmű volt, hogy ha valaki nem vásárolja meg az előírt mennyiségű részvényt, elveszítheti az állását” nyilatkozta egy állami vállalat alkalmazottja Jeanne Féaux de la Croix gyüjtésében 2014-ben (Féaux de la Croix-Suyarkulova [2015], p. 110).

A munka kultusza mellett a nemzetközi szolidaritás gondolata is háttérbe szorult. Ennek oka a szocialista népek közösségének felbomlása mellett a nagyméretü gátrendszerek kapcsán kialakult nemzetközi vita. Ezen rendszerek elterjedése ugyanis 
egyre több kérdést vetett fel az igazságosság, a fenntarthatóság, a hatékonyság, a részvétel és az elszámoltathatóság (Baghel-Nüsser [2010], p. 231) területein. A két álláspont képviselőinek vitája 1998-ban érte el a nemzetközi érdeklődés tetőfokát. Ekkor alakult meg a Gátak Világbizottsága (World Commission of Dams), mely 2000ben adta ki jelentését, ${ }^{21}$ javaslatokat téve a nagyméretü projektek ellentmondásosságának feloldására - amely kérdésben azonban azóta sem sikerült általánosan elfogadott áttörést elérni.

Ilyen körülmények között a nemzetközi donorszervezetek és államok igyekeznek minél több biztosítékot szerezni a fenti követelmények teljesülésére, mielőtt elfogadnák egy projekt támogatását. A korábbi szovjet tervek alapján épülő középázsiai gátrendszerek esetében igen sok hiányosság figyelhető meg, akár a társadalmi részvétel, akár a környezeti kockázatok, akár a puszta megvalósíthatóság területein, melyek hatására számos potenciális donor inkább távol marad a projektektöl. Oroszország az egyetlen jelentős szereplő, mely támogatást ígér például a Rogun gát megépítéséhez, ezen ígéretek teljesülése viszont egyértelmüen politikai alkukhoz kötött, és könnyen vissza is vonható.

A számos változás mellett egy fontos tényező a Szovjetunió felbomlása után is fennmaradt, sőt, a társadalmak viszonylagos nyitottabbá válásával még inkább előtérbe került. A kitelepítés kérdése jelenleg is aktuális, Tádzsikisztánban már 10000 föt telepítettek ki a Rogun gátrendszer építési munkálatai miatt, a tervekben pedig további 32000 fö szerepel (Féaux de la Croix-Suyarkulova [2015], p. 118). Az 1970-es évek kitelepítései még nem váltottak ki nagy visszhangot, napjainkban azonban más a helyzet. Kirgizisztánban a Toktogul víztározó építése miatt lakhelyüket elhagyni kényszerült lakosok jelenleg is kompenzációt követelnek az államtól (Féaux de la Croix [2011], p. 496). 2008 telén a víztározó jelentősen lecsökkent vízszintje mellett újra felszínre került néhány elárasztott falu az elhagyott használati tárgyakkal együtt, ami hozzájárult a kitelepítéssel kapcsolatos érzelmek felerősödéséhez (Féaux de la Croix [2014], p. 96). Bár a tádzsik kormányzat határozottan elítéli a peresztrojka korszakában a Rogun gát megépítése ellen folytatott, főként a kitelepítések ellen tiltakozó kampányt, hazafiatlannak ítélve mindenkit, aki hasonló elveket vall, Tádzsikisztánban is fennmaradt, sőt, megerősödött az ősök földjéhez, a hagyományos identitáshoz való ragaszkodás diskurzusa a kitelepítések kapcsán.

${ }^{21}$ WCD [2000]: „Dams and Development: A New Framework for Decision-Making.” 2000. november. URL: http://www.unep.org/dams/WCD/report/WCD DAMS\%20report.pdf, letöltés ideje: 2016. január 21. 
Az eltelt idő azt is bizonyította, hogy a nagyméretü gátrendszerek összességében nem váltották be a hozzáfüzött reményeket a jólét, a modernitás és a társadalmi igazságosság területein, különösen a Szovjetunió felbomlása és a közös vízigazgatási rendszer feldarabolása után. Pozitív hatásaikból főként egy szük elit részesül, a jólét nem jut el a társadalom szélesebb rétegeihez (Féaux de la Croix [2011], p. 496). A vízés energiaügyi létesítmények privatizációs kezdeményezései további kérdéseket vetnek fel, egyrészt a külföldi szerepvállalás (Féaux de la Croix [2010], p. 97), másrészt a helyi elit korrupciós ügyleteinek kapcsán (ld. Wooden [2014], p. 466). Az „ígéret” jelentéstartalma azonban megmaradt: Tádzsikisztán és Kirgizisztán nagyon határozottan a Rogun és a Kambar-ata I. gátrendszerek megépítésében látja a megoldást az állam problémáira (Suyarkulova [2014], p. 374).

A nagyméretü gátrendszerek és az állam- és nemzetépítés folyamatainak kapcsán azt is szükséges megemlíteni, hogy a jelenlegi vízigazgatási rendszer nem garantálja a lakosság megfelelő víz- és energiaellátását sem Kirgizisztánban, sem Tádzsikisztánban. Az alapvető fizikai szükségletek kielégítésének biztosítása elsődleges fontosságú lenne a kormányzatok legitimációjának biztosításában, annak hiányában a bizalmatlanság és a társadalmi feszültségek erősödését pusztán szimbolikus lépésekkel megelőzni nem lehetséges. A nagyszabású vízügyi projektek, melyek elvben képesek lennének ennek biztosítására, nem rendelkeznek megfelelő anyagi fedezettel, a nemzetközi támogatás bizonytalansága pedig komoly kockázatot jelent, nem beszélve a felmerülő, nagyrészt jelenleg is megválaszolatlan környezeti kérdésekről. A belső feszültségeket tovább növeli az építkezésekhez való kötelező hozzájárulás következtében kialakuló eladósodás. Jeanne Féaux de la Croix interjúi mindezek ellenére azt támasztják alá, hogy a lakosság még reménykedik abban, hogy a központi hatalom - az évszázados hagyományok szerint - képes lesz a vízellátás megfelelö szabályozására, és ennek révén a megfelelő mennyiségű energia biztosítására is. Amennyiben ez a hagyományos minta ezúttal nem valósul meg, az állam- és nemzetépítés folyamata, valamint a kormányzatok legitimitása komoly veszélybe kerülhet, Kirgizisztán és Tádzsikisztán viszonylagos stabilitása a belső feszültségek áldozatává válhat.

\section{5. Összegzés}

Az értekezés ezen fejezete három különböző jelenség elemzésének segítségével mutatta be az etnográfiai módszer hozzáadott értékét a vízmegosztással összefüggő 
államközi kapcsolatok vizsgálatában. Az öntözéses társadalmak klasszikus példája feltárta, hogy hogyan fonódik össze politika, gazdaság és társadalom a közép-ázsiai lakosság percepciójában a gyapottermesztés csomópontjában, és hogy mindez milyen szerepet ró a központi hatalomra a szükséges vízkészletek biztosításában, közvetlenül befolyásolva annak legitimációját. A szovjet időszakban kiépült nagyméretü gátrendszerek példája bemutatta, hogy milyen jelentéstartalmakkal bővült ekkor a vízügyek és a vízmegosztás diskurzusa, hangsúlyozva ezek beágyazottságát a szovjet „civilizációs misszióba”, melynek célja nemcsak a fejlődés és a modernizáció volt, hanem a gyakran a politikai ellenállás alapját képező hagyományos társadalmi szövetek felbontása és a minél szélesebb körü hatalom gyakorlása is. Az újonnan függetlenedő köztársaságok vezetői szintén felhasználták a nagyméretü gátrendszereket legitimációjuk megerősítésére és hatalmuk kiterjesztésére, de ebben az időszakban ez már az állam- és nemzetépítés retorikája révén társított jelentések által történt.

A három tárgyalt példa révén lényegesen közelebb kerülünk a jelenlegi középázsiai vízügyi konfliktushelyzetek megértéséhez, és láthatóvá válik, hogy egyértelmü kapcsolat áll fenn a politikai gyakorlat és az etnográfiai módszer révén feltárt ismeretek között. Mindhárom vizsgált példa azt mutatja, hogy az öntözéses gazdálkodás társadalmi hatásai meghatározó szerepet játszanak a közép-ázsiai köztársaságok életében, akár a hagyományos öntözéses gazdálkodás időszakát, akár a szovjet vízügyi „civilizációs misszió” eredményeit, akár a napjaink állam- és nemzetépítési törekvéseihez kapcsolódó vízügyi infrastrukturális fejlesztési terveket tekintjük.

A racionalista elméletek követői ebben az esetben gyakran elkövetik azt a hibát, hogy a jelenleg államokon belül és államok között is számos feszültséget okozó vízügyi kérdések megoldását egészen egyszerüen a gazdaság átstrukturálásában vélik felfedezni, a kevésbé vízigényes gabonanövények termelésére való áttérést sürgetve (Spoor [1993], pp. 153-154, Bobojonov et al. [2013]). A politikai-gazdasági-társadalmi kontextus ismeretében, az etnográfiai módszer alkalmazásával azonban láthatóvá válik, hogy ez a megoldási út a valóságban egyáltalán nem járható, hiszen az évszázadok alatt kialakult rendszerek magját, a vízügyi igazgatás és az azt irányító központi hatalom társadalmi szerepét sem a szovjet hatalom, sem a függetlenség nem volt képes megváltoztatni. Az elmúlt évtizedek során a vízügyek társadalmi beágyazottsága olyan új elemekkel egészült ki, melyek még inkább megerősítették szétválaszthatatlanságukat, mint például a modernitáshoz és az állam- és nemzetépítéshez kapcsolódó jelentéstartalmak. Egy esetleges gazdasági paradigmaváltás hatásai ezek következtében sokkal számottevőbbek lennének, mint ahogyan azt a kontextus ismerete nélkül gondolhatnánk. 
Az etnográfiai módszer alkalmazása nélkül tehát pusztán az államok harcát és a kevéssé hatékony, túlságosan vízigényes gazdálkodási módszerek problémáját láthatnánk a közép-ázsiai vízügyi kérdések középpontjában. Az etnográfiai módszer alkalmazásával azonban kiderül, hogy a kép sokkal árnyaltabb. A helyi viszonyok és hagyományok, a kultúra, az identitás, a normák, valamint az összefonódott gazdaságitársadalmi szerkezet ismeretében pedig olyan elemzések készülhetnek, melyek révén nemcsak az elméleti szakértők, hanem az esetleges segítő szándékú nemzetközi beavatkozás számára is sokkal nagyobb tér nyílhat a térségben. 


\section{AZ ÖSSZEHASONLÍTÓ FOLYAMATKÖVETÉS MÓDSZERE ${ }^{22}$}

\subsection{Az összehasonlító folyamatkövetés}

A folyamatkövető elemzés a kutató által felállított hipotézisek elfogadásához szükséges bizonyító erejü összefüggések szisztematikus feltárását és vizsgálatát jelenti (Collier [2011], p. 823). A módszert egyre gyakrabban kvalitatív jelleggel alkalmazzák a társadalomtudományok, köztük a nemzetközi kapcsolatok elmélete.

Az összehasonlító folyamatkövetés módszerének gyökerei történetileg jóval a konstruktivizmus megjelenése elé nyúlnak vissza, egyesek szerint akár Thuküdidészig (Bennett-Checkel [2012], p. 6). A klasszikus irodalomtudomány és történettudomány is folyamatkövető elemzéseken alapul, melyek lényege a feltételezett ok-okozati viszonyok feltárása és bizonyítása. Mindehhez hozzátartozik a széleskörü adatgyüjtés és alapos leírás, illetve a kutató által előzetesen megfogalmazott hipotézisek bizonyítása az összegyüjtött információk logikai összefüggéseinek vizsgálata során. Ezek a kutatások egyértelműen kvalitatív megközelítésen alapultak, és kumulatív jellegü tudományágakat eredményeztek. A „folyamatkövető elemzés” kifejezés az 1960-as és 1970-es években jelent meg és terjedt el, a kognitív pszichológia területéről kiindulva, ahol az emberi döntéshozatal magyarázatára alkalmazták a mentális folyamatok ok-okozati összefüggéseinek feltárását (Bennett-Checkel [2012], p. 8). A társadalomtudományok kezdetben szintén az egyéni döntéshozatal vizsgálatára alkalmazták a módszert, ami egyre szélesebb körben elterjedt, és szélesebb értelmet is nyert. A folyamatkövető elemzés annak módszerévé vált, hogy hogyan lehetséges a köztes lépések feltárásával kikövetkeztetni azt, hogy hogyan és miért megy végbe egy adott folyamat (BennettCheckel [2012], p. 8). A nemzetközi kapcsolatok elméletének behaviorista és szcientista megközelítések által dominált korszakában a folyamatkövető elemzések pozitivista és kvantitatív irányt vettek, de az 1990-es évek elejére visszataláltak eredeti, kvalitatív gyökereikhez.

Alexander L. George és Andrew Bennett ([2005], p. 206) definíciója szerint a folyamatkövető elemzés „történelmi források, archív dokumentumok, interjúk és más források használatát jelenti abból a célból, hogy bemutassuk, hogy egy adott

\footnotetext{
${ }^{22}$ A fejezet anyaga kis változtatásokkal publikálásra került a következő formában: Szálkai Kinga [2015]: „A vízmegosztás biztonságiasításának változásai Közép-Ázsiában (1960-2010). In: A biztonság szektorális értelmezése. Új kihívások a kutatás napirendjén. Szerk. Stepper Péter - Szálkai Kinga. Publikon, Pécs. 163-189.
} 
esettanulmányban az elméletileg feltételezett ok-okozati folyamat egyértelmüen következik a közvetítő változók sorrendiségéből és értékeiből.” A folyamatkövető elemzés kiválóan illeszkedik a konvencionális konstruktivizmus kereteibe, hidat képezve a racionalista és a konstruktivista megközelítések között, illetve megfelel azon konvencionális konstruktivista törekvéseknek is, melyek a kvalitatív módszerek szisztematikusabb alkalmazását tüzték ki célul (Collier [2011], p. 823).

A folyamatkövetés módszerének alkalmazása első látásra egyszerünek tünhet, hiszen egy, a statisztikai módszereknél vagy a tartalomelemzésnél szabadabb módszerről van szó, amelyet a mindennapokban is alkalmazunk, sikerét azonban nagymértékben meghatározza a megfelelő kritériumok és kategóriák felállítása melynek elmaradása esetében az elemzés nem töltheti be kitüzött céljait. A valóban tudományos folyamatkövetéshez a definíció alapján mindenekelőtt szükséges egy megfelelően meghatározott hipotézis, melynek bizonyítását az elemző ok-okozati összefüggések lépésről-lépésre történő feltárásával végzi el. Kutatásom e fejezetében a disszertáció alaphipotéziseihez kapcsolódva, illetve a koppenhágai iskola terminológiáját és szükebb elméleti keretét alkalmazva ez a feltételezés a következő: a közép-ázsiai politikai-gazdasági-társadalmi kontextus változásainak megfelelően módosuló vízbiztonsági percepciók egyértelmúen befolyásolják a vízmegosztás kérdésének biztonságiasításának folyamatát, időről-időre eltérő biztonsági szektorokban helyezve hangsúlyt a kérdésre, melynek révén ezen percepciók alakulása meghatározó a vízmegosztással összefüggő államközi kapcsolatok tekintetében. A fejezetben tehát a vízbiztonsági percepciók képezik vizsgálódásom fó fókuszát, ezek kialakulásának okokozati összefüggéseit tárom fel a folyamatkövető elemzés révén, bizonyítva azt, hogy ezek nagymértékben meghatározzák a vízügyekkel összefüggő államközi kapcsolatokban a biztonságiasítás megjelenését, illetve a vízügyek ezen kapcsolatokban megjelenő legfőbb értelmezési keretét, biztonsági szektorát.

A második kritérium az elemzés sikerességéhez az ok-okozati összefüggések megfelelően részletes leírása (Collier [2011], p. 823). A folyamatkövetés módszere leginkább abból a szempontból kötődik a racionalista elméletekhez, hogy az események, történések föbb elemeinek statikusságát feltételezi, a logikai összefüggések vizsgálatánál az elemzett tényezők alapvető változásait nem képes hatékonyan számításba venni. Emellett a konstruktivizmusban rendkívül nagy szereppel bíró kontextusok változásainak feltárására sem kifejezetten alkalmas eszköz, hiszen szinte kizárólag az ok-okozati összefüggések feltárására koncentrál (Checkel [2008], p. 116). Emellett azonban az is igaz, hogy ezen kapcsolódási pontok felismeréséhez alapvetően 
szükség van az adott statikus kontextus leírására, az időben kibontakozó folyamatok vizsgálata csak úgy lehetséges, ha megfelelő „pillanatképek” készülnek egy-egy időszakot illetően (Collier [2011], pp. 823-824). Mindezen hiányosságok kiküszöbölésére választottam jelen elemzéshez az összehasonlító folyamatkövetés keretét, ami nemcsak megoldja ezeket a módszertani problémákat, hanem két szempontból is jól illeszkedik a konvencionális konstruktivista elemzéshez. Az összehasonlító elemzés kiküszöböli a folyamatkövetés alapvető statikusságát, pozitivista és empirikus adatgyüjtésének jellegét pedig a kvalitatív jelleg ellensúlyozza. Értekezésemben történeti-tudományos leírásokat, szakcikkeket használok fel annak érdekében, hogy összehasonlítsam három időszak folyamatait, célom pedig kettős: Először is, minél részletesebb statikus leírást adni az adott időszakokban jellemző vízbiztonsági percepciókról, illetve arról, hogy ezek milyen ok-okozati összefüggések révén befolyásolják a vízügyi kérdések biztonságiasítását. Ezt követően pedig további célom az, hogy ezen különböző statikus leírások összevetésével releváns következtetéseket fogalmazzak meg a politikai-gazdasági-társadalmi kontextus, a biztonságpercepciók és az államközi kapcsolatok változásainak kapcsolódását illetően. A vizsgált három időszak összehasonlítása révén fontos összefüggések tárhatók fel ezen tényezők változásainak tekintetében, amire az egy időszakon belüli folyamatkövetés nem lenne alkalmas.

A sikeres folyamatkövető elemzés harmadik kritériuma a vizsgált szakaszok megfelelően részletes leírása (Collier [2011], p. 823), ami szorosan kapcsolódik a konstruktivista elemzésekben gyakran alkalmazott „sürü leírásokhoz”, ezzel újabb szoros kapcsolódási pontot mutatva az értekezésben alkalmazott elméleti keret és a folyamatkövetés módszere között. A következőkben tehát egyesével feltárom a Szovjetunió időszakában, az 1990-es években, és az ezredforduló utáni időszakban dominánssá vált vízbiztonsági percepciók kialakulásának okait, majd megvizsgálom hatásukat a vízügyi kérdések biztonságiasítása és az államközi kapcsolatok alakulása tekintetében.

\subsection{A Szovjetunió időszaka - Vízbiztonság a gazdasági szektorban}

A Szovjetunió időszaka megjelölés alatt az 1960-as években kezdődő, és a közép-ázsiai köztársaságok függetlenedéséig tartó időszakot értem, melyben a vízigényes gyapottermesztés és ezzel együtt az öntözéses gazdálkodás fejlesztése a hagyományos módszereken túllépve új lendületet kapott, melynek fó célja a 
gyapothozamok lehető legnagyobb mértékü megnövelése volt. Ennek dimenziói a korszakban már-már irracionális mértéket öltöttek, és hamarosan domináns szerepet töltöttek be a közép-ázsiai régió vízfelhasználásában és a köztársaságok vízmegosztással összefüggő államközi kapcsolataiban. Ahogyan a 3.1.3. fejezetben már bemutattam, a Szovjetunió tagköztársaságaiként a közép-ázsiai államok egy átfogó együttmüködés tagjaiként a vízmegosztásban is együttmüködtek egymással, míg a Szovjetunió gazdasági közösségén belül Moszkva egy közép-ázsiai regionális egységet is létrehozott.

A folyamatkövető elemzés szempontjából ezen együttműködési rendszerek legfontosabb pontjait érdemes újra kiemelni. A politikai-gazdasági-társadalmi kontextus szempontjából jelentős szerepet tölt be az a tény, hogy ebben az időszakban mesterséges munkamegosztás alakult ki a köztársaságok között, ami különösen az 1960-as évektől a világszínvonalú gyapottermelés szempontjait, elsősorban pedig az Amerikai Egyesült Államokkal folytatott versengést tartotta szem előtt. A Szovjetunió már Lenin óta (Micklin [1989], p. 14) önellátásra törekedett a gyapottermelés területén, illetve világpiaci részesedésének vezető szintre növelése is fontos célkitüzésnek számított. A világpiacon értékesített gyapot emellett jelentős forrása volt a külföldi „kemény” valutának. Mindezek alapján nem ok nélkül kapta a korszakban a „fehér arany” elnevezést (ld. Tarr-Trushin [2004].

Közép-Ázsiában Üzbegisztán és Kazahsztán jelentették a mezőgazdasági tevékenység össz-szovjet szempontból is kiemelkedő központjait, amelyekben a gyapot mellett a gabona termesztése is jelentős volt (Micklin [1983], pp. 13-14). Kirgizisztán és Tádzsikisztán kis mérete ellenére szintén részt vett a Szovjetunió gyapotellátásában, a különbségek azonban jelentősek voltak a nagyobb kiterjedésủ államokkal összevetve. 1986-ban például Tádzsikisztán az össz-szovjet termelés 11\%-át termelte meg, míg Üzbegisztán 61\%-át (Micklin [1989], p. 13). A gyapottermesztéshez szükséges éghajlati és hidrológiai körülmények a Szovjetunió területén a közép-ázsiai régión kívül csak Azerbajdzsánban álltak rendelkezésre (sokkal kisebb mértékben), ami tovább növelte az össz-szovjet gyapot több mint 90\%-át előállító régió fontosságát (Micklin [1983], p. 37; Micklin [1987], p. 82). Az 1980-as évekre a Szovjetunió a világ vezető gyapottermesztő hatalmává vált (Micklin [1989], p. 13).

A közép-ázsiai térség a központilag irányított munkamegosztáson alapulva képes volt a szovjet gazdaság regionális igényeinek megfelelő víz- és energiamennyiség biztosítására. 1987-től az Amu-darja tekintetében az egyes köztársaságokra jutó vízmennyiségről az 566. jegyzőkönyv rendelkezett. Eszerint Üzbegisztán a folyó 
vízhozamának 48,2\%-át, Tádzsikisztán pedig 15,45\%-át vehette igénybe, ami milliárd köbméterben 29,6-et, illetve 9,5-et jelentett. A fennmaradó vízmennyiségből

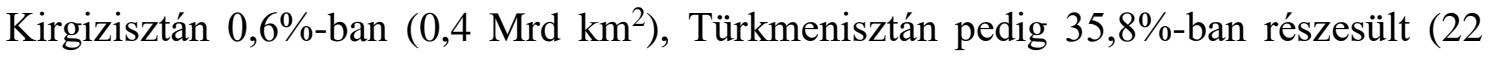
Mrd km²) (Ahmad-Wasiq [2004], p. 33). Ez a módszer biztosította, hogy a gyapottermesztő alvízi államok, különösen Üzbegisztán, elegendő vízhez jussanak a vízigényes ültetvények öntözéséhez. Eközben a felvízi államok főként Üzbegisztánból származó energiára és energiahordozókra cserélték vizüket, ezáltal minden tagköztársaság hozzájuthatott a számára szükséges erőforrásokhoz. Az együttmüködés fontos eleme volt, hogy a felvízi állam felelt a víztározók gazdaságilag hatékony müködtetéséért, a téli csapadékos időszakban feltöltve azokat, majd a gyapottermesztés legtöbb vizet igénylő szakaszában, tehát nyáron, biztosította az öntözéshez szükséges vízmennyiséget az alvízi állam számára (ICG [2014], p. 3).

Az együttmüködés általános kontextusának bemutatása után a következőkben egyesével áttekintem a politikai, a gazdasági és a társadalmi kontextus jellemzőit a vizsgált időszakban. A politikai kontextus alakulása esetében megfigyelhető, hogy a közép-ázsiai államok egyaránt abban volt érdekeltek, hogy integráns részét képezzék mind az össz-szovjet, mind a regionális vízigazgatási rezsimnek. Az államok, bár önálló köztársaságként rendelkeztek az ehhez szükséges intézményi struktúrával, ebben az időszakban nem folytattak Moszkva érdekeitől függetlenül értelmezhető politikai tevékenységet, működésük a szovjet érdekeknek alárendeltként zajlott, ezért nem volt elképzelhető a vízmegosztás kérdésének saját hatáskörben, magas szinten történő biztonságiasítása.

A gazdasági kontextus területén még inkább megfigyelhető a központi irányítástól való egyoldalú függőség. A tervgazdaság működése, a vizek központi igazgatása, illetve a közép-ázsiai munkamegosztás rendszere alátámasztja ezt a megállapítást. A társadalmi tényezők is hozzájárultak a vízügyi kérdések önálló biztonságiasításának korlátozásához. A szovjet kulturális minták átvétele, illetve az akkulturáció révén kialakult kettős norma (ld. Dobrovits [2011], p. 4; Dobrovits [2015], p. 104) megteremtette a függőségek átfogó rendszerének társadalmi beágyazódásához szükséges feltételeket.

A biztonsági percepciók e három tényező hatására a következőképpen alakultak: A köztársaságok biztonságuk megteremtésének kulcsát elsősorban a szovjet érdekekhez való alkalmazkodásban látták, míg másodsorban a regionális egymásrautaltság határozta meg biztonságuk alakulását, hiszen enélkül nem tudták volna előteremteni a számukra létfontosságú erőforrásokat, mint a gyapot, a víz és az energia. Az alkalmazkodás fontos 
tényezővé vált a biztonság és stabilitás garantálásában, és ez az együttmüködés felé mutatott. Bár a rivalizálás bizonyos szinteken megjelent, a központi hatalom és az együttmüködés kényszere képes volt arra, hogy irányítsa, kezelje vagy elnyomja ezeket a törekvéseket (Karaev [2005], p. 65). Az államok ebben a helyzetben elsősorban technikai és szakmai kérdésként kezelték a vízmegosztást, a politikai és a biztonsági szintre ritkán jutottak el a problémák. A biztonságiasítás ebben az időszakban egyértelműen a gazdasági szektorban jelent meg, különösen olyan esetekben, amikor a vízmegosztás a gyapottermesztéshez a Szovjetunió és a tagköztársaságok számára esszenciális fontosságú gazdasági erőforrásként kapcsolódott.

Jó példa lehet erre, hogy a rendelkezésre álló vizek „racionális” felhasználása a szovjet felfogásban a vizekhez kapcsolódó természeti erőforrások lehető legmagasabb szintű kihasználását, túlhasználatát jelentette, amit az Aral-tó katasztrófája egyértelmüen bizonyított is (Soucek [2000], pp. 8-9). E példa kapcsán érdemes hangsúlyozni azt a gondolatot is, hogy az általában „környezeti”-ként számon tartott kérdések nem automatikusan a környezeti szektor értelmezési keretében válnak biztonsági problémává. Az Aral-tó környezeti katasztrófája erre is jó példa, hiszen a szovjet korszak végéig, az 1980-as évekig nem jelent meg biztonsági kihívásként az állami diskurzusokban, annak ellenére, hogy a környezeti károk kétséget kizáróan jelen voltak (Soucek [2000], p. 8; Karaev [2005], p. 64). A vízkészletek fenntartható alkalmazása helyett a végletekig menő túlhasználatot a gyapottermesztés kiemelt fontossága indokolta. A vízkészletek tehát a gazdasági szektorban biztonságiasultak, lehető leggyorsabb és legnagyobb mértékü felhasználásuk kulcsfontosságú volt a gazdasági biztonság megteremtéséhez - az ültetvények ugyanis a szovjet központi hatalom véleménye szerint nagymértékben hozzájárultak ahhoz, hogy biztosítsák az állam önellátását és a nyugati blokktól való függetlenségét (Allouche [2004], p. 96). Az össz-szovjet gazdasági biztonság megteremtése emellett az egyes köztársaságok gazdasági biztonságához is hozzájárult, előteremtve az azok alapvető müködéséhez szükséges javakat - a központi hatalom döntéseivel való esetleges szembeszegülés pedig a gazdasági biztonság mellett más szektorokban is következményekkel járhatott volna.

\subsection{Az 1990-es évek - Vízmegosztás, a politikai biztonság egyik fő háttérfeltétele}

Az 1990-es években nem kis meglepetés érte azokat, akik konfliktust jósoltak a közép-ázsiai köztársaságok függetlenedése után. Konfliktus helyett ugyanis folytatódott 
az együttmüködés. A térség államai nem voltak felkészülve az önálló létre, így szinte vonakodva fogadták ennek lehetőségét (ICG [2002], p. 6). A korszak általános kontextusára az volt jellemző, hogy a közös (poszt)szovjet identitás és a függetlenség következményeiként kialakult politikai, gazdasági, társadalmi kényszerpályák elősegítették az együttmüködés szovjet mintáinak fenntartását (Allouche [2007], p. 46). A már létező és évtizedek óta müködő rendszerek és mechanizmusok fenntartása ugyanis sokkal kevesebbet igényelt az újonnan függetlenedett államok politikai, gazdasági és társadalmi kapacitásaiból, mint azok megváltoztatása, új rendszerek és mechanizmusok kialakítása. Így történt ez a vízigazgatás kérdésével kapcsolatban is, a közép-ázsiai államok bejelentették elkötelezettségüket a szovjet vízmegosztási kvóták fenntartására, és ennek érdekében - legalábbis elméletben - létrehozták a világ egyik legkomplexebb vízigazgatási rezsimjét.

A köztársaságok biztonsági percepcióit befolyásoló politikai-gazdaságitársadalmi kontextus ebben az időszakban több szempontból is hasonlóan alakult. A politikai kontextust általánosságban véve a belső instabilitás jellemezte. Bár a középázsiai államok többségében már a szovjet rendszerben is vezető pozíciót betöltő személyek kerültek hatalomra, a demokratikus berendezkedésre való áttérés megkezdése számos nagy erőforrás-igényü feladatot rótt az újonnan függetlenedett államokra. Emellett a nemzetközi rendszerbe való betagozódás is kihívást jelentett a politikai vezetés számára.

A gazdaság területén számottevő válság sújtotta a régiót. Az utódállamok ebből a szempontból is rendkívül szorosan kötődtek a Szovjetunióhoz, müködésük mindaddig a központosított tervgazdasági irányításnak rendelődött alá. Ennek a függő helyzetnek a megváltoztatása nem következhetett be egyik napról a másikra. Az alapvetően nyersanyag-kitermelésen és -előállításon alapuló közép-ázsiai gazdaságok válságát tovább fokozta az infrastruktúra egyoldalúsága, melynek kiépítésekor nem a helyi horizontális érdekek érvényesülését tartották szem előtt, hanem a központi hatalom elképzeléseit (Islamov [1994], pp. 203-204).

A társadalmat az átalakulás minden instabilitása sújtotta, az életszínvonal általános csökkenéséhez a munkanélküliség és a szociális háló felbomlása járult hozzá leginkább (Roudik [2007], pp. 165-168). Az újonnan függetlenedett köztársaságok társadalmi kohéziójának megteremtése, az állam- és nemzetépítés további jelentős erőforrásokat emésztett fel. A Szovjetunió felbomlása után tehát a közép-ázsiai köztársaságok helyzete a számos mesterségesen létrehozott függés hálózatainak széttöredezése miatt szélsőségesen kiszolgáltatottá vált, biztonságukban mind politikai, 
mind gazdasági, mind társadalmi szempontból fenyegetettséget érzékeltek, továbbá az önálló államként való megjelenés a nemzetközi színtéren is komoly kihívást jelentett.

Ezen instabil kontextus következményeképpen a közép-ázsiai köztársaságok biztonsági percepciói az államok politikai biztonságának megteremtése körül összpontosultak, amihez az elsődleges cél minél több alkalmazható erőforrás felszabadítása volt. Az 1990-es évek során a vízmegosztás területén kialakuló külpolitikai együttmüködés számos forrást szabadított fel az államok belső biztonsági helyzetének stabilizálása és a nemzetközi rendszerbe való külpolitikai betagozódása érdekében, fenntartása így az újonnan függetlenedett köztársaságok számára nagy fontossággal bírt, érdekérvényesítésük egyik alapjává vált.

Ezen megfontolások eredménye volt a közép-ázsiai államok multilaterális tárgyalásainak összehívása a vízmegosztás területén, melyek során elfogadták a legfontosabb dokumentumokat, amelyek megteremtették a regionális vízigazgatási rezsim kereteit. Ezen kereteket a 3.1.3. fejezetben részletesen ismertettem, így itt csak legfőbb csomópontjait tekintem át újra a korszak biztonságpercepcióinak bemutatása érdekében, illetve annak hangsúlyozására, hogy a vízmegosztás kérdése a vizsgált korszakban egyértelmüen a politikai szinten jelent meg.

A multilaterális vízmegosztási tárgyalások legjelentősebb állomása az 1992-es alma-atai egyezmény megkötése volt, melynek rendelkezéseiben a regionális közösség érdekei egyértelmüen felülírták az egyes entitások szándékait. Az egyezmény egyértelműen kimondta, hogy a közép-ázsiai államok elismerik a régió vizeinek egységét és birtoklásuk közös voltát, továbbá elkötelezik magukat a szovjet időszakban kialakult vízmegosztási struktúrák fenntartása iránt. A dokumentum főszövege nem tartalmazott olyan kezdeményezéseket, melyek a szovjet időszakban megállapított kvóták megváltoztatására irányultak volna, még annak tudatában sem, hogy ezek a megszünt Szovjetunió érdekein alapultak, és figyelmen kívül hagyták az egyes államok gazdasági fejlődésének igényeit, nehezen feloldható mesterséges különbségeket alakítva ki az alvízi és felvízi államok között (Allouche [2004], p. 100). A rendelkezések végrehajtására az alma-atai egyezmény létrehozta a Vízigazgatás Államközi Bizottságát (Interstate Commission for Water Coordination (ICWC), és ennek rendelte alá a szovjet időszak végén az Amu-darja és a Szir-darja vizeinek igazgatására létrehozott szerveket, fenntartva ezzel egy további szovjet eredetű struktúrát.

A közép-ázsiai vízigazgatási rezsim további szerződésekkel és kapcsolódó szervezetekkel bővült az 1990-es évek során, mint az 1993-as Aral-tó megállapodás, az 1995-ös nukuszi nyilatkozat, az 1999-es megállapodás az IFAS és szervezetei 
státuszáról, illetve az Aral-tó megállapodáshoz kapcsolódó Aral-medence Válságkezelő Államközi Bizottság és a Nemzetközi Alap az Aral-tó Megmentéséért (International Fund for Saving the Aral Sea (IFAS) (Allouche [2007], p. 48). A vízmegosztás kérdése így csak közvetett módon, éppen békés rendezésének szükségességével vált a biztonsági kérdések kezelésének kiegészítő részévé.

Az együttmüködésen alapuló szovjet vízigazgatási rezsim ideiglenes fenntartása tehát a függetlenséget követő instabil időszakban az újonnan önállósuló államok és politikai rendszereik számára a politikai biztonság megteremtésének, a stabilitás kialakításának egyik garanciájává vált. Bár a vízmegosztás mint biztonsági kérdés nem tartozott a kiemelt napirendi pontok közé, a vízügyi kérdésekröl folytatott multilaterális tárgyalások pedig elsődlegesen a politikai szinten tartották a problémák kezelését, egyértelmü, hogy mind ezek biztonságiasítása, mind a végleges rendezés elodázása az államok és rezsimjeik fennmaradása érdekében volt szükséges. Ugyanis, ha nem rendezik békésen a vízmegosztással kapcsolatos kérdéseket, ezek konfliktusokat eredményezhettek volna a köztársaságok között, ami további erőforrások felemésztésével jár - ez pedig akár az államok összeomlásához is vezethetett volna. Az erőforrások megőrzése viszont lehetővé tette ezek felhasználását az aktuálisan az államok politikai biztonságára nagyobb veszélyt jelentő problémák megoldására.

$\mathrm{Az}$ is megfigyelhető, hogy a környezeti kérdések - elsősorban az Aral-tó kérdésével kapcsolatban - ebben az időszakban kiemelkedően fontos elemét képezték az államközi kapcsolatoknak. Ebben az esetben is látható azonban, hogy a környezeti kihívások nem a biztonság, hanem a politikai kérdések szintjén jelentek meg elsősorban, a környezeti szektorban ezúttal sem ment végbe lényegi biztonságiasítási folyamat. A környezet megóvását és helyreállítását fontos célként kezelő egyezmények, intézmények és tárgyalások politikai szinten történő megvalósulása a stabilitás fenntartásához járult hozzá - miközben az egyértelműen artikulált biztonsági kihívás az újonnan önállósodott államok fennmaradása volt, aminek előfeltétele volt a stabilitás.

\subsection{0 után - Vízbiztonság a gazdasági és politikai szektorban}

Az ezredfordulót követően a korábbitól gyökeresen eltérő tendenciákkal szembesülhetünk a közép-ázsiai vízmegosztással összefüggő államközi kapcsolatokat illetően. A belső konszolidációt és a nemzetközi rendszerbe való betagozódást követően a közép-ázsiai államok egyre kevesebb elkötelezettséget mutatva vettek részt az együttmüködés egyeztető folyamataiban, az 1990-es évek során aláírt szerződések 
rendelkezései a gyakorlatban hiányosan és egyre kevésbé valósultak meg. Üzbegisztán például úgy döntött, hogy az energiahordozók árait a korábbi kedvezményes árszabás helyett piaci módszerekkel határozza meg, ami a Tádzsikisztánnal való barterkapcsolat elhalásához vezetett (Allouche [2007], p. 48). A kvóta- és barteregyezmények nem teljesülése komoly következményekkel járt a regionális munkamegosztás működése területén. Bár a térség felvízi országai a világ legnagyobb vízienergia-potenciáljával bíró államai közé tartoznak, a szovjet igazgatás alatt a nem történt meg ennek hatékony kihasználása, az erőmü-rendszer teljes kiépítése a tervek ellenére nem valósulhatott meg a Szovjetunió felbomlása miatt. Az energiaellátás eközben szinte kizárólag az alvízi országokból érkező energiahordozókra épül, ami kiszolgáltatottá teszi a felvízi államokat (ECS [2013], p. 35). A felvízi állami érdekek tehát egyértelmüen a vízkészlet növekvő felhasználása felé mutatnak, az energia- és élelmiszer-termelés fokozása nélkülözhetetlen a régió két legszegényebb országa számára.

A felvízi és alvízi államok között a szovjet időszakban kialakított egyensúly tehát a központi irányítás megszünésével a kezdeti biztató eredmények ellenére igen törékenynek bizonyult. Az energiaszükösség miatt a felvízi államok a rendelkezésre álló vízenergia egyoldalú hasznosítására kezdtek törekedni, amit az alvízi államok egyértelmü biztonsági fenyegetésként érzékelnek. Ez a folyamat azt mutatja, hogy a konszolidáció és stabilizáció után a közép-ázsiai államok arra a következtetésre jutottak, hogy vízellátásuk biztonságának kérdéseit, valamint az ezekhez kapcsolódó politikai, gazdasági és társadalmi biztonsági kihívásokat leginkább egyoldalúan, a másik féllel való konszenzuskeresés nélkül lehetnek képesek kezelni. Így az erőforrások feletti szuverenitás hangsúlyozása révén maximalizálhatják a rendelkezésre álló javakat, illetve garantálhatják az állam biztonságát. Az államközi kapcsolatokban így megnövekedtek a feszültségek, a tendenciák egyre komolyabb konfliktushelyzet kialakulását vetítik előre.

A kontextus szélesebb körü összefüggései is ebbe az irányba mutatnak. Politikai szempontból a közép-ázsiai államok számára az állam- és nemzetépítés folyamatai dominálnak (March [2002]; Blakkisrud-Nozimova [2010]). A gazdasági kontextust illetően a kialakult viszonylagos gazdasági stabilitás hatására egyre inkább előtérbe kerül a fejlődés szükségessége. Például Üzbegisztán esetében ez a gyapotföldek kiterjesztésében, Tádzsikisztán esetében pedig egyrészt szintén az öntözött területek növelésében, másrészt az energiatermelés fejlesztésében jelenik meg. Az államok ezen, a vízkészleteket is érintő befektetések által katalizált gazdasági folyamatokban látják biztosítva fejlődésüket - amelyek csak új erőforrások bevonása által kivitelezhetőek. 
Mindez egy olyan régióban történik, ahol az erőforrásokért folytatott versengés egyre fontosabb jellemzőjévé válik az államközi kapcsolatoknak. A társadalmi kontextus szempontjából elmondható, hogy a létrejött viszonylagos stabilitás a társadalom egyre nagyobb szegmensében fejti ki pozitív hatásait, azonban jelenleg is számos olyan réteg van jelen, melyek gazdaságilag kiszolgáltatott, bizonytalan helyzete fenyegetést jelenthet az államok számára. A hatalom a szociális biztonság megteremtésével, az alapvető javak garantálásával tarthatja meg az itt is jelenlévő viszonylagos stabilitást, amihez elengedhetetlen fontosságú a gazdasági növekedés, az általános fejlödés és modernizáció.

A közép-ázsiai köztársaságok viszonylagos stabilitása az ezredforduló után teret nyitott a hosszú ideig háttérbe szoruló nemzeti érdekeknek. Ezek kapcsán viszont számos olyan probléma merül fel, melyek feszültségek kialakulásához vezethetnek közöttük, és láthatóan nem rendezhetőek mindkét állam számára kielégítő módon. Ezek között fontos szerepet kap a természeti erőforrások feletti szuverenitás kérdése (Karaev [2005], p. 65), ezen belül is a nemzetközi folyók használatának szabályozása, a vízmegosztási kérdések újratárgyalása. Az Aral-medence vizei körül ennek következtében egy szélsőségekig is elmenő párbeszéd alakult ki, melyben zéróösszegü játékként jelenik meg az Amu-darja és mellékfolyói vízkészleteinek megosztása (ICG [2002], p. ii).

Az ebben a párbeszédben megjelenő biztonságpercepciók egyértelműen arról árulkodnak, hogy az államok számára rendkívül fontos kihívássá vált a gazdaságitársadalmi fejlődéshez szükséges vízkészletek biztosítása (vagyis a vízfelhasználás növelése), mi több, ez egyre gyakrabban a túléléshez szükséges motívumként jelenik meg az államok vezetőinek retorikájában. A vezető szerepet betöltő társadalmi szereplők kijelentéseiben az tükröződik, hogy a természeti erőforrások, különösen a szükös vízkészletek feletti kizárólagos hatalom nagymértékben hozzájárul a biztonság és stabilitás megteremtéséhez és megőrzéséhez - a fejlődéshez szükséges stabilitást leginkább igénylő társadalmi rétegek pedig támogatják ezt az elképzelést. Az államok felfogásában ennek következtében az együttmüködésnél több elérhető hasznot garantálhat a konfliktus (vagy legalábbis a konfliktus retorikája), ami elősegíti az állam alapvető érdekeinek érvényesülését - az együttmüködés fenntartása ezért többé nem kifizetődő a biztonság szempontjából.

A vízmegosztás kérdése tehát ebben az időszakban egy folyamatos biztonságiasítás alanyává vált, a szakmai és a politikai szférából a biztonság szférájába emelkedve. A szektorokat illetően arról még nem beszélhetünk, hogy a gazdasági és 
politikai megközelítések helyett a katonai szektor lenne a probléma értelmezésének legfőbb kerete, a háború egyértelmü kockázata azonban gyakran megjelenik a kialakult diskurzusban (Wunderer [2009], pp. 744-745). 1996-ban például Üzbegisztán azzal fenyegette meg Kirgizisztánt, hogy katonai erővel foglalja el a Toktogul víztározót és gátját, ha Biskek megkísérli megváltoztatni a kialakult vízmegosztás rendszerét (Allouche [2007], p. 49). Ebből a példából is látható, hogy a konfliktus kialakulását sok esetben materiálisan determináltnak tekintik az objektíven értelmezett vízszűkösség felfogásának megfelelően (Shlomi [2012], pp. 131-134). Emellett az is egyre egyértelmübbé válik, hogy a vízmegosztás körül kialakult viták a nemzetközi kapcsolatokban megszokott módon súlyosbítják a már fennálló egyéb konfliktusokat is az államok között, mint például Üzbegisztán és Tádzsikisztán között az etnikai feszültségeket és a határok kérdését, ami szintén a katonai szektorbeli értelmezés egyre szélesebb körű alkalmazása felé mutat (Makhmedov et al. [2012], pp. 10, 12-13).

A vizsgált négy állam kapcsolatait elemezve egyetlen állampár képez kivételt az általánosan jellemző konfliktusos tendenciák alól, mégpedig a Kirgizisztán-Kazahsztán diád. Ebben az esetben is jelen van a politikai szférában az állam- és nemzetépítés folyamata, valamint az állami szuverenitás és az államérdek kiemelt fontossága. Kirgizisztán gazdasági szempontból éppolyan kiszolgáltatott, mint Tádzsikisztán, a Kazahsztánhoz hasonlóan alvízi Üzbegisztán pedig hasonló retorikát folytat Kirgizisztán és Tádzsikisztán ellen, főként mezőgazdasági érdekeinek védelmére. Kazahsztán számára szintén fontos a déli területek mezőgazdasága, ennek ellenére nem lép fel támadóan a Tádzsikisztánhoz hasonlóan vízerőművek építését tervező Kirgizisztán ellen. A társadalmi kontextust tekintve a körülmények szintén nagyon hasonlóak: Kirgizisztán társadalmi békéje és fejlődése szempontjából kulcsfontosságú a megfelelő energiaellátás biztosítása, míg a dél-kazah mezőgazdaság vízellátása szintén nagy fontossággal bír a terület lakossága számára.

A politikai-gazdasági-társadalmi kontextus tehát megegyezik a térség más, konfliktusos területeivel, a vízmegosztással összefüggő kirgiz-kazah államközi kapcsolatok azonban az együttmüködés felé tendálnak. Ez persze nem jelenti azt, hogy egyáltalán ne lennének feszültségek a két állam között: Kazahsztán határozottan fellép annak érdekében, hogy a kirgiz vízügyi létesítmények építése, használata és müködtetése összhangban álljon a kazah érdekekkel (pl. Interfax [2012]), és időrőlidőre komolyabb viták is felmerülnek (pl. Lillis [2013]). A két állam között azonban főként az együttmüködés dominál. Kazahsztán igyekszik saját érdekei mentén előmozdítani például a Kambar-ata I. építkezéseit, amihez akár közvetlen pénzügyi és 
szakértői segítséget is hajlandó küldeni (Kazinform [2012a]), ahelyett, hogy Üzbegisztánhoz hasonlóan arra törekedne, hogy ellehetetlenítse azokat. A vizsgált négy állam kapcsolatait tekintve egyedül Kazahsztán és Kirgizisztán között nem áll fenn a vízügyekhez kapcsolódó határvita (Allouche [2007], p. 48). A Csu-Talasz vízgyüjtő területén kialakult rezsim kialakulása és fenntartása (ld. 3.3.2. fejezet) pedig egyértelmü jele a vízbiztonsági diskurzusok együttműködésre irányuló voltának. A két állam közötti általános kapcsolatokban alapvetően az együttmüködés diskurzusai dominálnak. Asztana és Biskek között gyakori az egyeztetés, a két állam hagyományosan jó, „testvéri” kapcsolatai jelentős szerepet töltenek be, és kölcsönhatásban állnak a vízbiztonsági diskurzusok alakulásával is. A Csu-Talasz megállapodás kapcsán a szakirodalom gyakran hivatkozik arra, hogy a térségben egyedi együttmüködési kezdeményezés sikerének hátterét a meglévő jó kapcsolatok és informális hálózatok biztosították (Wegerich [2008], p. 118). A wendti barátságosság és ellenségesség diskurzusaiból tehát egyértelműen az előbbi határozza meg a kirgiz-kazah viszonyokat. Mindezek fényében levonható a következtetés, hogy ebben az esetben a vízbiztonsági (és más, államközi kapcsolatokra vonatkozó) diskurzusok nem a kontextus közvetítése révén hatnak a két állam vízügyekkel összefüggő államközi kapcsolataira, hanem önmagukban, független változóként jelennek meg. A kirgiz-kazah együttmüködésben emellett erős a szakértői dimenzió, a szakmai szint jelentősége is, ami elősegíti a vízügyi kérdések közös kezelését.

A környezeti biztonság kérdésének megjelenésére jó példa a Tádzsikisztán által tervezett Rogun gát körül kialakult diskurzus (ld. 3.3.1. fejezet; Világbank [2014]), melyben Üzbegisztán amellett érvel, hogy a gát megépítése hatalmas környezeti kockázattal jár, üzbég területeken jelentős károkat okozó földrengéseket, árvizeket eredményezhet. Ebben az esetben valóban megfigyelhetjük a kérdés környezeti biztonsági szektorban való megjelenését is, hiszen Taskent érvelésében egyértelmüen a természeti környezet és az emberi civilizáció kapcsolatában létrejövő fenyegetésről van szó, mely veszélyezteti Üzbegisztán egyes területeinek lokális bioszféráját, a lakosságot és környezetüket. Ebben az esetben azonban, a jelen alfejezet gazdasági, politikai és katonai szektorra egyaránt alapuló elemzésével összevetve az is megfigyelhető, hogy a pusztán a környezeti szektorra, a bioszférára koncentráló elemzések számos egyéb jelentős körülményt hagynának figyelmen kívül, melyek nagymértékben befolyásolhatják a gyakorlatban a nemzetközi kapcsolatok alakulását. Példánk tehát alátámasztja Buzan és szerzőtársai megállapítását arra vonatkozóan, hogy a biztonság szektorokra bontása nem öncélú, a külön-külön megvizsgált elemek újra-összeillesztése 
által egy áttekinthetöbb és pontosabb képet kaphatunk az államközi kapcsolatokban zajló folyamatokról és azok befolyásoló tényezőiről (Buzan et al. [1998], p. 167).

\section{5. Összegzés}

Az értekezés ezen fejezetének célja az volt, hogy ok-okozati összefüggések vizsgálatának segítségével feltárja a Szovjetunió időszakában, az 1990-es években, és az ezredforduló utáni időszakban dominánssá vált vízbiztonsági percepciók kialakulását, illetve ezek hatásait a vízmegosztás biztonságiasítása és az államközi kapcsolatok alakulása tekintetében. A vizsgált időszakok tapasztalatai egyértelmüen bemutatják, hogy a politikai-gazdasági-társadalmi kontextus által alakított vízbiztonsági percepciók változásai azt eredményezték, hogy a vízbiztonság kérdése különböző szektorokban vált elsődlegessé, ami nagymértékben befolyásolta az ezzel összefüggő államközi kapcsolatok alakulását. Emellett az is láthatóvá vált az elemzés során, hogy a különböző szektorokra kerülő hangsúlyváltozások időszakai ezen esettanulmányban egybeesnek a biztonságiasítás szintjeinek (szakmai, politikai, biztonsági szférában való értelmezés) változásával (ld. 3. ábra).

A Szovjetunió időszakában, amikor egy központi hatalom irányította (és kényszerítette ki) az együttmüködést a közép-ázsiai köztársaságok között, a vízmegosztás biztonságiasítási folyamata egy meglehetősen alacsony szinten, a gazdaság szakmai kérdéseinek szférájában ment végbe. A Szovjetunió gazdasági biztonságának biztosításához ugyanis a gyapotágazat minél nagyobb termelékenységére volt szükség az adott kontextusban, (ami a közép-ázsiai köztársaságok esetében a nyilvánvaló központi szankciós lehetőségek miatt a gazdasági biztonságon kívül további szektorális elemekkel is kiegészült), amihez a kulcsfontosságú elemet a leginkább hozzáértő szakértők tudása jelentette. Az államok a szovjet keretek miatt ebben az időszakban nem voltak érdekeltek abban, hogy önállóan magasabb, politikai vagy biztonsági szinten fogalmazzák meg a vízbiztonsághoz kapcsolódó érdekeiket és céljaikat.

Az 1990-es évek időszakában, amikor a vízmegosztás kérdése leginkább másodlagos problémaként kapcsolódott a politikai biztonság kérdéséhez, és rendezésének későbbre halasztása az erre fordítandó erőforrások felszabadulásával segítette elő az államok fennmaradását, a belső politikai rendszer stabilizálását, illetve a nemzetközi rendszerbe való betagozódást, a vízmegosztás kérdése a politikai tárgyalások és megállapodások szintjén manifesztálódott. Az ezek során kialakult 
komplex vízigazgatási rezsim az 1990-es évek során képes volt arra, hogy kordában tartsa az államok önérdekét, a regionális érdeket emelve magasabb szintre, és elkerülve a vízmegosztás kérdésének biztonságiasulását.

A harmadik vizsgált időszakban, vagyis az ezredforduló után, egyre inkább megfigyelhető egy olyan tendencia, ahol a vízmegosztás kérdése a katonai szektorban biztonságiasul, explicit és implicit fenyegetéseket vonva maga után az államközi kapcsolatokban. Emellett a kérdés ebben az időszakban már nem másodlagos problémaként jelenik meg a politikai biztonság szektorában - az állam- és nemzetépítés kiemelkedő fontosságú folyamatai jelentősen befolyásolják a vízbiztonsági percepciókat is, melynek eredményeképp a vízkészletek megosztásának kérdéséhez jelenleg a politikai szektor képezi az elsődleges értelmezési keretet.

Összefoglalva elmondható tehát, hogy a vízmegosztással összefüggő államközi kapcsolatokban megfigyelhető a politikai-gazdasági-társadalmi kontextuson alapuló biztonságpercepciók egyértelmű hatása arra nézve, hogy a biztonság melyik szektora válik leginkább hangsúlyossá az adott időszakban jellemző biztonságiasítási folyamatban. A szektorelméleti vizsgálódásoktól függetlenül, a közép-ázsiai államok kapcsolatainak vizsgálata összességében a folyamatkövető elemzés eszközeivel is alátámasztotta az etnográfiai módszer segítségével már bizonyított megfigyelést, miszerint a politikai-gazdasági-társadalmi kontextuson alapuló biztonságpercepciók befolyásolják azt, hogy a vízmegosztás kérdése szakmai, politikai vagy biztonsági kérdésként jelenik meg az adott állam felfogásában. 


\section{6. fejezet}

\section{A DISKURZUSELEMZÉS MÓDSZERE}

\subsection{A diskurzuselemzés}

A diskurzuselemzés az etnográfiai módszer alkalmazásához hasonlóan a társadalomtudományok, különösen a filozófia egy XX. századi „fordulatához” kapcsolódik, méghozzá az úgynevezett nyelvi-hermeneutikai fordulathoz. A nyelvihermeneutikai fordulat gyakorlatilag megfordítja a korábbi tudományos világképet, amelyben a nyelv egyszerüen a valóság egy semleges közvetítő eszköze, melynek révén a tények megismerhetővé tehetők. A fordulat lényege, hogy elveti a világ nyelven keresztül megismerhető és semlegesen leírható objektív valóságának képzetét. A nyelvet ehelyett olyan eszköznek látja, melynek segítségével jelentéseket társíthatunk a világ jelenségeihez, legyenek azok tárgyak vagy tapasztalatok. Ezeket a jelentéseket aztán szervesen a tárgyakhoz, tapasztalatokhoz tartozónak tekintjük, olyanformán, mintha valóban egy objektív valóságról lenne szó (Carver [2002], p. 50). A diskurzuselemzés ezeket a jelentéstársítási folyamatokat igyekszik vizsgálni, sok esetben dekonstruálni, annak érdekében, hogy feltárja ezen folyamatok mozgatórugóit, illetve a nyelv szerepét a jelentések létrehozásában és fenntartásában. A nyelv és a szöveg tehát a jelentésekhez hasonlóan szintén társadalmi konstrukciónak tekinthető, mely az adott időszakban jelenlévő percepciókról kialakuló diskurzusokat rögzíti, közvetíti és reprodukálja. „A diskurzus tehát annak a reprezentációja, hogy milyennek szeretnénk látni a világot, és nem annak, hogy milyen a világ valójában" (Carver [2002], p. 51). Mindezzel együtt egyértelművé válik a diskurzusokban megjelenő elsődleges hatalmi mechanizmus is, méghozzá az „igazság”, vagyis a domináns vagy hegemón diskurzusok kialakulása, mely általában valamiféle autoritáshoz köthető. John Austin ezt már az 1950-es években kiegészítette a beszédcselekvés fogalmával, mely egyértelmüen a valóságot konstruáló erőként értelmezte az elhangzott vagy leírt szöveget (Virág [2014], p. 30), mely szintén igen jelentős, paradigmaváltó hatással bírt a társadalomtudományokban, megteremtve az alapot többek között a koppenhágai iskola biztonságfelfogásához is.

Bár a diskurzuselemzés ilyen szempontból már régóta jelen van a társadalomtudományokban, széles körben elterjedt empirikus alkalmazása igazán csak az 1990-es években vált elterjedtté (Szabó [2003], p. 73). Nem véletlen, hogy éppen a 
konstruktivizmus térnyerésével esik egybe ez az időszak, hiszen, ahogyan a fentiek alapján már egyértelmü lehet, talán a diskurzuselemzés tekinthető a „legkonstruktivistább” módszernek. Szabó szerint a nyelvi-hermeneutikai fordulat eredményeképpen egy narratív vagy diszkurzív fordulat is létrejött a társadalomtudományokban, ahol a vizsgálódások fókusza a narratívák felé fordul, hiszen ezeket tekinti a jelentések legfontosabb hordozójának és közvetítőjének (Szabó [2003], p. 43). A narratívák Szabó értelmezése szerint „olyan a valóságot meggyőzően prezentáló elbeszélésmódok, melyek rögzítik és stabilizálják a jelentéseket, egységes kontextusokat hozva létre" (Szabó [2003], p. 52). Az érzékelt valóságot tulajdonképpen ezek gyakori ismétlése és folytonos megerősítése tartja fenn (Neumann [2008], p. 66). Jelen fejezet elemzési módszere követi ezt a felfogást, vizsgálódásának célja ilyen narratívák feltárása.

Az értelmezési keret tisztázásához ki kell azonban emelni azt a tényt is, hogy a diskurzuselemzés alkalmazásáról, vagy akár a diskurzus-fogalom jelentéséről és vizsgálhatóságáról sem alakult ki közmegegyezés a társadalomtudományokban. A nyelv szubjektív természetére való puszta odafigyeléstől (Carver [2002], p. 53) a legmélyebb nyelvi struktúrák elemzéséig szinte bármi tekinthető (és nevezhető) diskurzuselemzésnek, ezért jelen kutatás szempontjából is meghatározó fontosságú a használt fogalmak és módszer magyarázata, a kutatás elhelyezése a diskurzuselemzés irodalmában.

A számos irányzat különbözősége ellenére két fő tendencia egyértelmüen megfigyelhető. Az első a Foucault-i hagyományokra építve a nyelvi, nyelvtani struktúrák müködésére, a nyelv valóságot alakító szerepére és a valósággal való kölcsönhatásaira helyezi a hangsúlyt, aminek vizsgálatához alapvetően lingvisztikai alapokra épít. Fő célkitűzése a nyelvhasználat mögött húzódó hatalmi mechanizmusok feltárása és dekonstrukciója, a konfrontálódás az „igazság”, a „tény” és az „érték” fogalmaival (Carver [2002], p. 53). Michel Foucault szerint „a diskurzus nemcsak egyszerüen tolmácsolja a küzdelmeket és az uralmi rendszereket, hanem érte folyik a harc, általa dúl a küzdelem; tehát a diskurzus az a hatalom, amelyet az emberek igyekeznek megkaparintani” (Foucault [1970/1991]) Ezt a felfogást gyakran kritikai diskurzuselemzésnek nevezik.

A másik irányzat ennél jóval kevésbé merül el a nyelvi struktúrák elemzésében, ehelyett a diskurzusokat rögzítő szövegek, narratívák tartalmára helyezi a hangsúlyt. (Ennek során tulajdonképpen a kvalitatív tartalomelemzés módszerének irányába is elmozdul, de a csak a szöveges elemeket vizsgáló tartalomelemzéssel szemben a 
diskurzuselemzés a kontextusra, a politikai-gazdasági-társadalmi beágyazottságra koncentrál, annak gyökereit igyekszik feltárni.) Fő célkitüzése annak feltárása, hogy adott témák milyen jellegü jelentéstartalmakat kapnak a vizsgált szövegekben megjelenő diskurzusok során, illetve, hogy ezen jelentéstársítási folyamatok milyen kapcsolatban állnak az adott társadalmi kontextussal, és milyen interakciókat rögzítenek a társadalmi szereplők között (Gee [2011], p. 8). A hatalmi struktúrák feltárása természetesen ebben a felfogásban is elkerülhetetlenül jelen van, hiszen a fentiek vizsgálata enélkül nem valósulhatna meg, a hangsúly azonban kevésbé helyeződik erre, mint a kritikai diskurzuselemzés esetében. Ez a felfogás gyakran leíró diskurzuselemzés néven szerepel.

A jelen disszertációban alkalmazott módszer a második felfogást követi, annál is inkább, mivel a konvencionális konstruktivizmus alapvetései mentén való vizsgálódást ez az utóbbi teszi lehetővé a leginkább. Iver B. Neumann ([2008], p. 62) megfogalmazását követve feltételezem, hogy a diskurzus ,,a rendszeresség egy szintjét tartja fenn a társadalmi kapcsolatokban, megteremti a cselekvés előfeltételeit. Korlátokat szab annak, hogyan rendeződnek el a világ dolgai, és így annak is, hogy az emberek milyen kategóriákban gondolkodnak a világról. Korlátokat szab annak, hogy mi lehetséges, és mi a „természetes” egy adott helyzetben. A diskurzus azonban nem determinálja a cselekedeteket. Mindig több mint egy lehetséges végkimenetel van.”

Disszertációm ezen fejezetében tehát azon vízbiztonsági diskurzusok alakulásának a feltárására fókuszálok, melyek, akár önmagukban, akár a politikaigazdasági-társadalmi kontextus változásait közvetítve, kölcsönhatásban állnak a vízmegosztással összefüggő államközi kapcsolatok változásaival. Az általam kiválasztott, hegemonisztikus diskurzusokat rögzítő szövegekben azt figyelem meg, hogy a határon átnyúló vízfelületek témájához a „konfliktus” vagy az „együttmüködés” narratívái, jelentéstartalmai társulnak-e a vízmegosztással összefüggő államközi kapcsolatokhoz. Mindezzel azt bizonyítom, hogy az előző két fejezetben csak feltételezett jelentéstársítások valóban, nyomon követhetően és tudományosan vizsgálható módon megtörténnek. A jelentéstársítási folyamatok vizsgálata lehetővé teszi annak közvetlen elemzését, hogy hogyan alakíthatóak, változtathatóak a vízbiztonsági diskurzusok, melyek, hipotézisem értelmében (és a két korábbi módszer vizsgálódásaiból levont következtetésekből is láthatóan) egyértelmüen befolyásolják a vízmegosztással összefüggő államközi kapcsolatok változatosságának alakulását. Mindennek révén a diskurzuselemzés konstruktivista módszertana túllép a materialista és racionalista elméletek statikus természetén, illetve már nemcsak a változás 
értelmezésének teret enged, hanem a változtatások megvalósításához, a kialakult helyzetek tudatos alakításához is teret nyit, cselekvőképességet ad a diskurzusok résztvevői számára.

Jelen fejezetben tehát a konvencionális konstruktivizmusnak leginkább megfeleltethető leíró diskurzuselemzés alkalmazásával vizsgálom meg a közép-ázsiai vízbiztonsági diskurzusokat, arra fókuszálva, hogy a határon átnyúló folyók témájához milyen narratíva társul a vízmegosztással összefüggő államközi kapcsolatok tekintetében. Ez a gyakorlatban azt jelenti, hogy az együttműködés és a konfliktus jelentéstartalmainak változását vizsgálom a választott szövegek mondatok feletti narratív struktúrájában. Ehhez olyan szövegeket használok fel, melyek intézményesített diskurzusokat rögzítenek ezekről a témákról, narratívákról.

A fejezet első felében a folyamatkövető elemzésnél és az etnográfiánál már alkalmazott három időszakban folytattam le az elemzést: a szovjet időszak 1960-tól 1990-ig tartó szakaszában, az 1991-től 1999-ig tartó együttműködési periódusban, és a növekvő feszültségeket mutató 2000-es években. Mindhárom időszakban három típusú forrást vizsgáltam meg: 1) vízügyekkel kapcsolatos nemzetközi jogi dokumentumokat, 2) tudományos összefoglalókat, 3 ) állami hírügynökségek híreit.

A vízügyekkel kapcsolatos nemzetközi jogi dokumentumok kapcsán egyaránt elemeztem multilaterális és bilaterális szerződéseket, illetve a Szovjetunió időszakában az államközi kapcsolatok speciális jellegéből adódóan belső szabályozásokat is figyelembe vettem. A szerződések számának növekedését egy adott korszakon belül az együttmüködés, csökkenését pedig a konfliktusos értelmezések és a feszültség növekedésének jeleként értelmeztem.

A tudományos összefoglalók esetében, mivel ezekből álltak rendelkezésemre a legszéleskörübb források, további három kategóriát alkalmaztam: 1) könyvek, 2) nemzetközi szervezetek jelentései, 3) szakcikkek, melyek közül két-két gyakran idézett, feltételezhetően domináns diskurzusokat rögzítő példát választottam ki. A nemzetközi jogi dokumentumok és a tudományos összefoglalók típusukból adódó jellegzetessége, hogy egyrészt politikailag elfogadott álláspontokat tesznek közzé, másrészt pedig hosszú évek összegyüjtött tapasztalatainak hivatalosan, a lakosság számára közzéteendő értelmezéseit tartalmazzák.

Az állami hírügynökségek híreinek esetében feltételezem, hogy ezek a források, már csak típusuk, meghatározásuk révén is, a hivatalos, intézményesített, „kanonizált” diskurzust rögzítik. Az állami hírügynökségek angol nyelven megjelent online hírei az állam által elfogadott, a nemzetközi közösség számára közzéteendő domináns 
diskurzusokat jelenítenek meg. Ezek a források az aktuális állami álláspontokra világítanak rá kompromisszumra törekvés nélkül, az a tény pedig, hogy ezeket idegen nyelvre fordítják, szintén azt mutatja, hogy hivatalosan elfogadott, a hallgatóság számára a politikai vezetőség szándékainak megfelelő formába öntött szövegekről van szó, melyek fő célja gyakran a nemzetközi közösség megnyerése az állam prioritásainak támogatására. A fejezet második felének célja, hogy kiegészítse az eddig tárgyaltakat a 2010 végétől napjainkig terjedő időszak diskurzusainak vizsgálatával. Ehhez szintén az állami hírügynökségek híreit használom fel, ez esetben azonban részletesen elemezve azok tartalmát és a mögöttük húzódó jelentéstartalmakat.

\subsection{Konfliktus vagy együttmüködés? Vízügyi diskurzusok Közép-Ázsiában²3}

\subsubsection{Vizügyi diskurzusok I.: A szovjet időszak}

A határon átnyúló folyók vízkészleteihez társított jelentéseket a folyamatkövető elemzés korszakolásához hasonlóan először is a Szovjetunió időszakában, méghozzá 1960 után vizsgálom meg, ugyanis ebben az időszakban indult meg a gyapottermesztés és ezzel együtt az öntözéses gazdálkodás nagyarányú fejlesztése, kiterjesztése KözépÁzsiában. Ennek dimenziói a korszakban már-már irracionális mértéket öltöttek. Mint a folyamatkövető elemzés már feltárta, ekkor a közép-ázsiai köztársaságok és vezetőik egyaránt abban volt érdekeltek, hogy integráns részét képezzék mind az össz-szovjet, mind a regionális vízigazgatási rezsimnek, melyek kiemelkedő szerepet játszottak identitásuk alakulásában. Emiatt a jellegzetesség miatt nemcsak a vizsgált két állampár esetében, hanem a teljes régiót tekintve is az együttmüködés jelentéstartalmai társultak meghatározó módon a vízmegosztási kérdésekhez.

Az ebben az időszakban kialakult vízmegosztási diskurzusok vizsgálatához célszerü megvizsgálni a vízügyekkel kapcsolatos, a Szovjetunió egészére kiterjedő szabályozásokat tartalmazó dokumentumokat. A legmeghatározóbb ilyen dokumentum A vízügyi szabályozás alapelvei a Szovjetunióban és tagköztársaságaiban, melyet 1970. december 10-én fogadtak el. Eszerint (3. cikk) a Szovjetunió vizei egyetlen egységes rendszert képeznek, mely az állam kizárólagos tulajdona, és csupán használatra vehető igénybe. Ebben az értelemben a vízigazgatás a központi hatóságok kizárólagos jogává

\footnotetext{
${ }^{23}$ A fejezet anyaga a szerző mesterszakos szakdolgozatának egy átdolgozott része, lásd: Szálkai Kinga [2012]: „Water Issues Are What States Make of Them: A Constructivist Approach to Conflict and Cooperation over Trans-Boundary Waters." Chapter Two: The Relations of Uzbekistan and Tajikistan over the Amu Darya. Central European University, International Relations and European Studies MA. URL: www.etd.ceu.hu/2012/szalkai_kinga.pdf, letöltés ideje: 2016. augusztus 22.
} 
vált (41. cikk), a vízmegosztási megállapodások egy Moszkvából irányított össz-szovjet rendszer részeként jöttek létre. A „víz” fogalom jelentése (ellentétben az általános szovjet felfogással) ebben az esetben sokkal komplexebb területeket fed le, mint a „vizek” materiális valósága. Bár a felhasználás „racionalitásának” követelménye gyakran megjelenik, az Alapelvek nemcsak gazdasági, hanem politikai és társadalmi szempontból is áttekintik, szabályozzák a vízügyeket (Ld. 1. cikk).

A dokumentum gyakorlatilag rögzíti a határon átnyúló folyókra vonatkozó, központilag igazgatott együttműködés meghatározó szerepét a vízbiztonsági diskurzusokban. Az össz-szovjet diskurzus együttmüködés-központúságát jól kiegészíti a regionális együttmüködés-központúság, melynek diskurzusát az állami dokumentumok közül az 5.2. alfejezetben részletezett 566. jegyzőkönyv [1987] rögzítette. A jegyzőkönyv a közös erőfeszítések és a munkamegosztás fontosságára helyezte a hangsúlyt a határon átnyúló folyók kérdésében. A központilag meghatározott vízügyi kvóták ezen célkitüzéseket voltak hivatottak előmozdítani, alkalmazkodva a közép-ázsiai államok regionális munkamegosztásban betöltött szerepéhez. Az állami dokumentumok vizsgálata tehát jól mutatja, hogy a vizsgált időszakban az együttmüködés fogalma társult a közép-ázsiai vízbiztonság kérdéséhez.

A tudományos forrásokat illetően is hasonló tendenciák figyelhetőek meg a diskurzuselemzés eszköze révén. Annak ellenére, hogy ezen források nagy része a későszovjet biztonsági és környezeti problémákra reflektál, szinte mindegyik tartalmazza a közép-ázsiai gazdasági egység és munkamegosztás gondolatát, rögzítve ezzel a korabeli domináns diskurzust, akár az 1980-as években (Micklin [1989]), akár a kétezres évek elején (Weinthal [2006], pp. 5-6) íródtak. Gyakran szó esik ezekben a cikkekben a szovjet vízigazgatási rendszer erőteljes központosításáról (Karaev [2005], p. 62), az Aral-tó vízgyüjtőjének egységes kezeléséről (McKinney [2004], p. 188), illetve arról a nagyon jelentős szerepről, amit Moszkva, illetve a szovjet vízügyi minisztérium töltött be a bartermegállapodások és kvóták meghatározásában a közép-ázsiai térségben (Allouche [2004], p. 99). Mindezek szorosan összefonódnak az együttmüködés fogalmával, és jól mutatják annak jelentőségét a korabeli domináns diskurzusban.

A vizsgált tudományos források emellett sok esetben utalnak a vízkészletek „racionális” felhasználására, ami a szovjet gyakorlatban azok lehető legmagasabb szintű kihasználtságát jelentette (Soucek [2000], pp. 8-9). A „racionális” vízfelhasználás gondolata a szövegekben összekapcsolódik az Aral-tó vízgyüjtő területének egységes igazgatásának és az öntözött földterületek erőltetett kiterjesztésének leggyakrabban megjelenő indoklásával, vagyis az önellátás biztosításával és a Nyugattal folytatott 
versengéssel (Allouche [2004], p. 96). A szövegek ezáltal reprodukálják azt a gondolatot, hogy mindezek eléréséhez a domináns szovjet diskurzus szerint együttmüködésre volt szükség a régió államai között - és ezen célok fényében ez az együttmüködés a domináns diskurzus részeként elkerülhetetlennek és szükségesnek tünt, mint a térség kölcsönös vízügyi függéseinek természetes következménye.

A vizsgált szövegek harmadik csoportja, az állami hírügynökségek hírei szintén alátámasztják az együttmüködés jelentéstartalmának vízbiztonsághoz való társítását a domináns diskurzusban. Gyakran utalnak az egységes vízigazgatási rendszerre, aminek hangsúlyozásaképpen például az is megjelenik, hogy napjaink közép-ázsiai vezetői sokszor a szovjet időszakban megállapított kvótákra hivatkoznak, amikor az államaik számára szükséges vízmennyiség biztosításának körülményeiről tárgyalnak (Stevenson [2011]). Az állami hírügynökségek híreiben sorozatosan feltünő elem még az általában igen negatív konnotációban megjelenő szovjet ,irracionalitás”, ami főként a nagyszabású öntözési rendszerek kiépítésének és ezek erőltetett kiterjesztésének káros társadalmi, egészségügyi és környezeti hatásai kapcsán merül fel. A felelősségre vonó hangsúlyok ellenére ezek a cikkek is gyakran utalnak a szovjet öntözési rendszerek figyelemreméltó komplexitására és egységére, a munkamegosztás jelentőségére (Khovar [2012]) - ami mind-mind az együttmüködés gondolatának domináns diskurzusát rögzíti. Összességében véve, a vizsgált állami hírügynökségek hírei is az együttmüködés diskurzusának domináns voltát támasztják alá.

A szovjet időszakkal kapcsolatos, illetve az annak diskurzusait rögzítő, rekonstruáló, reprodukáló szövegek áttekintése után tehát mind a jogi dokumentumok, mind a tudományos források, mind az állami hírügynökségek hírei azt mutatják, hogy ebben az időszakban egy együttműködés-központú jelentéstartalom társult a vízbiztonsági diskurzusokhoz, feltételezve az Aral-tó vízgyüjtő területének egységét, hangsúlyozva az össz-szovjet és a regionális vízigazgatás központosítottságát, illetve elfogadva ezek szükségességét. Ebben a központilag irányított egységességben a kutatásom során vizsgált állampárok ellentétei nem jelentek meg a domináns diskurzusban annak ellenére, hogy ezek gyökerei már ebben az időszakban is jelen voltak. A központi igazgatás szigorú rendszerében, a Szovjetunió érdekeit érvényesítő politikában nem volt helye a belső ellentéteknek, ezek, a források tanúsága szerint, csak a későbbi időszakokban kerültek felszínre. 


\subsubsection{Vizügyi diskurzusok II.: Az 1990-es évek}

A második vizsgált időszak az 1990-es évtized, melynek során föként a Szovjetunió felbomlása és annak következményei határozták meg a közép-ázsiai államok fó prioritásait. Amint a folyamatkövető elemzésnél már áttekintettem, a függetlenség kikiáltása után számos politikai, gazdasági és társadalmi probléma került felszínre. Az egyes köztársaságok politikai napirendje helyzetük stabilizálásától függött, ami teljes kapacitásaikat lekötötte. Mindez egy olyan biztonságpercepció kialakulásához vezetett, mely szerint a már meglévő, szovjet gyökerü együttmüködések fenntartása hozzájárul a stabilizációs folyamatokhoz, legalább annyiban, hogy átalakításuk és újratárgyalásuk nem vesz igénybe újabb, szükös kapacitásokat és erőforrásokat. A vízigazgatás kérdése tipikusan ilyen jellegü terület volt, az államok egy széleskörü multilaterális rezsim létrehozásával igyekeztek garantálni a szovjet eredetü együttműködési mechanizmusok (barteregyezmények, vízmegosztási kvóták) fenntartását. Ennek érdekében a korszakban számos nemzetközi szerződés született, melyek írásos bizonyítékként rögzítik az együttmüködés narratíváját a közép-ázsiai viszonyokban. Azt is érdemes kiemelni, hogy az 1990-es évek szerződéseiben az értekezésben vizsgált államok egyaránt részt vettek, a dokumentumok narratívái pedig a regionális együttmüködést helyezik előtérbe az egyes nemzetállami érdekekkel szemben. A térség tehát ebben az időszakban is megtartotta egységét a vízügyeket illetően, tehát az alábbiakban nem indokolt a vizsgált Tádzsikisztán-Üzbegisztán és Kirgizisztán-Kazahsztán állampárok megkülönböztetése ebből a szempontból.

Az 1990-es évek legfontosabb vízügyekkel kapcsolatos nemzetközi jogi dokumentum az 1992-ben született alma-atai egyezmény volt. A dokumentumban megjelenik az együttmüködés és a közös vízigazgatás elemi fontossága; a közös politikák, a közös érdekérvényesítés és a közös szervezés-irányítás minden egyes érintett államot egyaránt szolgáló igénye, valamint a vízhez való egyenlő jogok és felelősségek kérdése. Az egyezmény explicit módon elismeri a köztársaságok érdekeinek „felbonthatatlan interdependenciáját,” és a fogyasztás közös szabályozása mellett érvel (Preambulum). Mindezek értelmében, követve a korábbi szovjet megfogalmazást, kimondja a régió vizeinek „közösségét és egységét,” (1. cikk) és rögzíti a részes államok ehhez kapcsolódó kötelezettségeit. A dokumentumban határozottan megjelenik ,a vízmegosztás már kialakult struktúrájának és alapelveinek tiszteletben tartása" (Preambulum), illetve annak követelménye, hogy az egyes államok vízfelhasználása, illetve az államok területén ehhez kapcsolódó tevékenység nem eredményezhet káros hatásokat más államok területén, nem sértheti a régió többi 
köztársaságának érdekeit (3. cikk). Az idézetekből nemcsak a régió egységként való kezelésének szándéka válik nyilvánvalóvá, hanem az arra való törekvés is, hogy a térség közös érdekei írják felül az államok nemzeti érdekeit, fenntartva ezzel a vízkészletek hozzáférésében megnyilvánuló egyenlőséget is. A dokumentumban nem található olyan kezdeményezés, mely arra irányulna, hogy megváltoztassa a szovjet gyökerü vízigazgatási rendszert Közép-Ázsiában. (Egy kivétel megfigyelhető azonban: Tádzsikisztán szándéka arra, hogy megnövelje öntözött földterületeit (Preambulum).) Mindez elmondható az 1990-es években kialakított komplex vízügyi rezsim más egyezményeinek kapcsán is. Ezek a dokumentumok egyértelmüen reprodukálják a korabeli domináns diskurzust, mely az együttmüködés jelentéstartalmait társítja a vízbiztonság kérdéséhez.

A régió egészét magába foglaló multilaterális egyezmények mellett két- és többoldalú megállapodások is születtek a vízügyi kérdésekkel kapcsolatosan (ICG [2002], p. 9). Ezek a megállapodások tükrözték az államok egymásrautaltságát és a vízi erőforrásokhoz kapcsolódóan gyakran ellentétes érdekeit, de egyértelmüen az együttmüködés szellemében születtek meg. Ilyen volt például az 1998-as tádzsik-üzbég megállapodás a víz- és energiafelhasználás kölcsönös ésszerüsítéséről, melyet a rákövetkező két évben folyamatosan megújítottak, illetve a szintén 1998-ban kötött „Megállapodás a Kazah Köztársaság, a Kirgiz Köztársaság és az Üzbég Köztársaság kormányai között a Szir-darja-medence víz- és energiaforrásainak felhasználásáról,” melyhez 1999-ben Tádzsikisztán is csatlakozott.

A vizsgált tudományos források szintén alátámasztják ennek a jelentéstartalomnak a jelenlétét, üdvözölve a „nagyon elörehaladott vízügyi együttmüködést” (Allouche [2007], p. 53). A tudományos anyagok többsége felsorolja a közép-ázsiai vízügyi megállapodásokat (Weinthal [2006], pp. 7-9) és az intézményeket (Allouche [2007], p. 48.), melyeket egy összetett rezsim részeként kezelnek, még akkor is, ha központi állításukkal éppen a konfliktus valószínüsége mellett érvelnek. Több forrás üdvözli az együttmüködés-központú szovjet vízigazgatási módszerek fenntartását (McKinney, [2004], p. 218), és hangsúlyozza, hogy ezek a konfliktus-megelőzés kiváló eszközeiként müködnek a térségben (Wunderer [2009], p. 742), hozzájárulva annak „csendes békéjéhez” (Allouche [2004], p. 100).

Mindezeket kiegészítve, az állami hírügynökségek hírei is az együttmüködés jelentőségét hangsúlyozzák a korszak vízügyeivel összefüggésben. Bár napjainkban az erre való utalás többnyire puszta retorikai eszközként jelenik meg, a közös múltra és a közép-ázsiai államok vízügyi (és egyéb) közösségére való reflexiók rendszeresen 
megjelennek ezekben a cikkekben. A jelenbeli együttmüködés hiányára utaló mondatok mögött pedig egyértelműen ott van az a tartalom, hogy létezett egy olyan időszak, amikor a mára kiüresedett kooperáció gondolata valós jelentéssel bírt, mint például a következő esetben is: „A regionális együttmüködés agyonhasznált fogalom KözépÁzsiában... és olyan sokszor visszaéltek már vele, hogy napjainkra már nem beszélhetünk másról, mint egy elcsépelt és értéktelen kliséről.” (Stevenson [2011]).

Mindezek alapján levonható tehát a következtetés, hogy a Szovjetunió felbomlása utáni időszakban a közép-ázsiai térség államai figyelmen kívül hagyták a vízkészletek feletti konfrontálódás perspektíváit. Ehelyett a regionális vízigazgatási rendszerek közös fejlesztésére koncentráltak, az együttmüködés jelentéstartalmát társítva a vízbiztonság kérdéséhez.

\subsubsection{Vizügyi diskurzusok III.: Az ezredforduló után}

A harmadik vizsgált időszak a 2000 utáni évtizedet foglalja magába, melyre egy igen radikális fordulat jellemző a közép-ázsiai vízügyi kérdések területén az együttműködés irányából a konfliktusos, feszültségekkel terhelt államközi kapcsolatok felé. Ennek a fordulatnak a fő oka az, hogy az újonnan függetlenedő köztársaságok saját nemzeti érdekeiket nyíltan a regionális közösség érdekei fölé emelték. A nemzeti szuverenitás, a nemzet- és államépítés folyamatai olyan érdekeket helyeztek előtérbe, melyekkel kapcsolatban csak igen szük tere maradt a megállapodásoknak, az együttműködésnek. A vízkészletekért is megindult a versengés, a határon átnyúló folyókhoz pedig ezáltal egyre konfliktusosabb jelentéstartalmak társultak a régió egészét tekintve. Ebben az időszakban válik el egymástól a kutatásban vizsgált két állampár: Üzbegisztán és Tádzsikisztán kapcsolataiban ugyanis, a regionális tendenciáknak megfelelően, folyamatosan növekszik a feszültség, míg Kazahsztán és Kirgizisztán ritka kivételt képezve igyekszik megtalálni az együttmüködés lehetőségeinek és a nemzeti érdekek követésének optimumát.

Az első állampár tekintetében vizsgálódva az új nemzetközi jogi dokumentumok hiánya az első szembetünő elem ebben az évtizedben. Multilaterális szempontból az egyetlen jelentősebbnek mondható dokumentum az „Akcióterv az Aral-tó vízgyüjtő területének környezeti, gazdasági és társadalmi helyzetének javítására a 2003-2010 közötti időszakban" [2002], melyet 2003. augusztus 28-án fogadtak el mind az öt köztársaság részvételével. Az itt megfogalmazott kötelezettségek betartását azonban a korábbiaknál is kevésbé vették komolyan az államok, megragadva a kínálkozó 
lehetőségek nagy részét arra, hogy áthágják az akciótervben meghatározott célkitüzéseket, ha ezen az úton több előnyt reméltek (Allouche [2007], pp. 46-47). A tádzsik-üzbég bilaterális szerződések sem jelentettek komolyabb elkötelezettséget, különösen azért, mert ad hoc módon figyelmen hagyták ezek rendelkezéseit, melynek révén gyakoriak az újratárgyalások is (ICG [2002], p. 9). Összességében, bár az évtizedből származó nemzetközi jogi dokumentumok szövege követte a korábbi megállapodásokat, melyek az együttmüködés fogalmát társítják a határon átnyúló folyókhoz, ezen dokumentumok minimálisra csökkenő száma, illetve legitimitásuk csökkenése azt mutatja, hogy a határon átnyúló folyókhoz kapcsolódó jelentéstartalmak megváltoztak.

Erről részletes képet kaphatunk a tudományos és a zsurnalisztikai források alapján. A tudományos forrásokban egyértelmüen megjelenik a konfliktus mint a vízügyekhez egyértelmüen kapcsolódó jelentéstartalom, és háttérbe is szorítja az együttmüködésről szóló diskurzusokat. A vizsgált forrásokban Üzbegisztán és Tádzsikisztán viszonyában a vízmegosztás „magas kockázatot hordozó feszültségként”, egy „forró pontként” (Kipping [2009], p. 711) jelenik meg, mely nagy valószínüséggel folyamatosan erősödő további feszültségekhez, akár fegyveres összecsapásokhoz, vagy háborúhoz is vezethet a két állam között. A tudományos anyagok gyakran hangsúlyozzák az előrejelzett konfliktushelyzet materiális meghatározottságát (Dinar [2012], pp. 131-134), abszolút vízszükösségről, feloldhatatlan feszültségekről írva. Eközben fontos célkitüzésük ezen feszültségek csökkentése, a konfliktusok megoldásának megtalálása és a kialakult helyzetek eszkalációjának elkerülése, amit policy-jellegü ajánlások megfogalmazásával igyekeznek elérni, vagy legalább közelebb hozni (ICG [2002], pp. iii-iv). Szemléletes kifejezéseket használnak a vízkészletekért folytatott versengés leírására, több alkalommal megemlítve az „ellentétek növekedésének” (Makhmedov et al. [2012], p. 10) ,ijesztő mértékét” (ICG [2002], p. i), illetve gyakran utalnak arra is, hogy a vízfelhasználás „fenntarthatatlan mértéke” „dühöngő és gyülölködő nyilvános nyilatkozatokat” (Makhmedov et al. [2012], p. 5, 11) eredményez az állami vezetők részéről. Mindezek a gondolatok összefonódnak a regionális vízigazgatási rendszer kudarcáról írottakkal (Makhmedov et al. [2012], p. 11). Elmondható tehát, hogy ezekben a szövegekben a vízmegosztással összefüggő államközi kapcsolatok domináns szerepet játszanak, és súlyosan konfliktusos kérdésként jelennek meg Üzbegisztán és Tádzsikisztán között, melyek hozzájárulnak a két állam közötti más típusú feszültségek súlyosbodásához is, mint például az etnikai 
kisebbségek vagy a vitatott határok kérdéseinek esetében (Makhmedov et al. [2012], p. $10,12-13)$.

Az állami hírügynökségek hírei még részletesebb képet adnak a konfliktus domináns diskurzussá válásáról a 2000-es években, hangsúlyozva a határon átnyúló vízfelületek jelenlétéből fakadó, szükségszerüként értelmezett feszültségeket, illetve a kapcsolódó viták zéróösszegüjáték-természetét (Khovar [2012]). A Rogun vízerőmü kapcsán, mely mindkét fél számára rendkívül fontos, radikálisan különbözőek a bemutatott álláspontok (ld. Makhmedov et al. [2012], p. 8). A tádzsik fél amellett érvel, hogy „a projekt biztonságos és esszenciális fontosságú a régió számára” (Khovar [2012]), míg üzbég források csak „öngyilkosság”-ként (Umarova et al. [2011]) emlegetik a tervezett vízerőmüvet. Mindkét állam újságírói vízhiányról panaszkodnak, és természetes szükségletként igyekeznek feltüntetni vízigényüket. A cikkek szerint a vízkészletek biztosítása az egyetlen út a vágyott nemzeti önállóság elérésére (Ivanova [2011]), így az államok csak ,,a nemzet ellensége”-ként említik riválisukat (Makhmedov et al. [2012], p. 12.). Önmagukat ezzel szemben a vízkészletek „racionális felhasználására” (Umarova et al. [2011]) törekvő szereplőként ábrázolják, akik az egész régió javát akarják (Khovar [2012]) - vagy a vízerőmü felépítésével, vagy pedig annak megakadályozásával, még annak ellenére is, hogy a regionális együttmüködés a cikkek többsége szerint csak ,értéktelen klisé” (Stevenson [2011]). Az együttmüködésre hivatkozó források nagy része leginkább a nemzetközi közösségnek szól, és támogatás nyújtására kívánja rávenni azt - amit az államok saját érdekeik érvényesítésére használnának fel.

Összességében elmondható, hogy a Tádzsikisztán-Üzbegisztán állampár esetében a vízügyekkel kapcsolatos nemzetközi jogi dokumentumok számának csökkenése, az ezek betartására irányuló törekvések gyengülése, valamint a konfliktusközpontú tudományos elemzések, illetve az állami hírügynökségek híreinek feszültségkeltő retorikája egyértelműen mutatja az együttmüködési törekvések kudarcait, a megerősödő rivalizálást és a nemzeti érdekek dominanciáját a regionális érdekek felett - vagyis azt a tényt, hogy a vízügyi kérdésekhez kapcsolódó domináns diskurzusban a konfliktus a fő megjelenő jelentéstartalom.

A Kirgizisztán-Kazahsztán állampár esetében azonban más a helyzet. Bár, amint a folyamatkövető elemzés során már áttekintettem, a politikai-gazdasági-társadalmi kontextus nem tér el jelentősen a két vizsgált állampár esetében, Asztana és Biskek mégsem a konfrontálódást, hanem az együttmüködést választotta a köztük fennálló alvízi-felvízi kérdések rendezésére. A két állam között éppen a vizsgált évtized 
kezdetén, 2000-ben indult meg a vízügyi együttmüködést rögzítő dokumentumok új generációja, igaz, nem átfogó módon, vagy a Szir-darját illetően, hanem a 3.3.2. fejezetben bemutatott Csu-Talasz-medencét illetően.

A Csu-Talasz megállapodás, vagyis a „Megállapodás a Kazah és Kirgiz Köztársaság kormányai között a kormányközi státuszú vízigazgatási létesítmények használatáról a Csu és Talasz folyón" [2000] egyértelműen rögzíti a vízkészletek megosztásához társított együttmüködési narratívát. A dokumentum preambuluma kimondja, hogy a felek ,nagy jelentőséget tulajdonítanak a kölcsönösen előnyös együttmüködésnek a vízkészletek kapcsán,” és tiszteletben tartják a jószomszédság, az egyenlőség és a kölcsönös segítségnyújtás elveit. A felek megállapodtak abban, hogy a kormányközi státuszú vízigazgatási létesítmények esetében a felhasználó állam, vagyis Kazahsztán kompenzálja a fenntartó, tulajdonos államot, azaz Kirgizisztánt, amivel a két állam közös felelősséget vállal ezen létesítmények fenntartásában, és ezzel együtt a vízkészletek kölcsönösen előnyős, fair és egyenlő megosztásában. A két állam vízmegosztásbeli egyenlőségét és együttműködését mutatja a Csu-Talasz Bizottságot létrehozó statútum szövege is, mely rögzíti a két fél egyenlő jogait a megállapodást intézményesítő szövegben is (A Csu-Talasz Bizottság Statútuma [2006]).

A tudományos szövegek vizsgálata a Csu-Talasz megállapodás kapcsán megerősíti, hogy valóban az együttmüködés diskurzusa dominál a kirgiz-kazah vízügyi kapcsolatokban, bár azt sem tagadja, hogy ennek kialakulása nem folyt zökkenőmentesen. A tudományos szövegek ,jelentős sikerekről” és „számottevő hasznokról” (Bure [2008], p. 131), valamint „mérföldkőről” (Mirumachi [2013], p. 168) és „,nagy áttörésröl” (Wegerich [2008], p. 117) írnak az együttmüködés kapcsán, kiemelve, hogy „Közép-Ázsiában nem létezik más hasonló együttműködésre épülő projekt” (Bure [2008], p. 131). A szövegek emellett hangsúlyozzák a Csu-Talasz megállapodás mintapélda-szerepét is a régió egésze, illetve a nemzetközi szervezetek vízügyi szerepvállalása számára (Wegerich [2008], p. 129; Libert-Lipponen [2016], p. 178). Emellett kiemelik azt is, hogy mindez „érzékeny körülmények” (Bure [2008], p. 137) között alakult ki, de ez leginkább azt mutatja, hogy ,a vízügyeket illető közel tíz évnyi stagnálás és konfliktusos helyzetek sorát követően az együttmüködés új korszaka kezdődött meg” (Wegerich [2008], p. 117). Az együttmüködésbe bevont nemzetközi szervezetek (EBESZ, UNECE, UNESCAP) dokumentumai (UNECE [2015], UNECEOSCE [2011]) szintén arról tanúskodnak, hogy a Csu-Talasz megállapodás által létrehozott keretek között valós együttmüködés zajlik. 
Az állami hírügynökségek híreiben megfigyelhető diskurzusok szintén alátámasztják az együttmüködés jelentéstartalmának a vízmegosztás kérdéséhez való társítását. A Csu-Talasz-medencében kialakult rezsimmel kapcsolatban, a megállapodás 15. évfordulójára több cikk is megjelent a kirgiz médiában, amelyek az együttmüködés sikereit és jövőbeli perspektíváit hangsúlyozták. „Fontos, hogy a víz a versengés helyett az együttmüködés forrása legyen" - nyilatkozta Julija Minajeva, az EBESZ biskeki munkatársa a jubileumi konferencián a résztvevő nemzetközi szervezetek oldaláról (Kabar [2015b]). Janibek Kerimaliev, a kirgiz mezőgazdasági minisztérium miniszterhelyettese pedig ugyanezen a rendezvényen a következőképpen írta le az együttmüködés jelentőségét: „A Csu-Talasz Bizottság jól megérdemelt elismerést kapott globális szinten, ami, remélhetőleg, hozzájárul a [kirgiz-kazah] barátságos kapcsolatok tovább erősítéséhez, valamint a békés és fenntartható fejlődéshez, nemcsak a mi államaink, hanem az egész közép-ázsiai régió számára” (Kabar [2015a]). A nemzetközi szervezetek szerepvállalása és befektetései/támogatásai általában jelentős visszhangot kapnak a kirgiz online médiában (Kabar [2013d]). A kazah állami hírportál oldalain ritka a specifikusan a kirgiz-kazah vízügyi együttmüködést bemutató cikk, az általános államközi kapcsolatok leírásánál azonban általában megjelenik a vízmegosztás, mint azok egyik fontos dimenziója. Ilyen általános cikkek utalnak például a Csu-Talasz-mintájú együttmüködés kiterjesztésére a Karküra folyón (Kazinform [2009]), ismertetik a Bisztratak államközi öntözőcsatornánál kialakult feszültségek miniszterelnöki szinten megvalósult tárgyalásos megoldását (Kazinform [2013]), illetve hírt adnak a vízügyi létesítmények felújításánál és megépítésénél nagy segítséget jelentő kirgiz-kazah befektetési alap létrehozásáról (Kazinform [2012]).

A vizsgált diskurzusok tehát mind a nemzetközi jogi dokumentumokban, mind a tudományos forrásokban, mind az állami hírügynökségek híreiben az együttmüködés jelentéstartalmának dominanciáját mutatják a kirgiz-kazah vízmegosztással összefüggő államközi kapcsolatokban az ezredfordulót követően. A nemzetközi megállapodások léte már önmagában is eltérő tendenciát mutat a régióban megfigyelhető általános folyamatoktól, az együttműködés folytonos, bár lassú pozitív irányú fejlődése pedig egyedül itt tapasztalható Közép-Ázsiában. A tudományos források is ezt a trendet hangsúlyozzák, kiemelve az együttmüködés példaértékét az egész régió számára. Az állami hírügynökségek híreiböl kiderül, hogy Kirgizisztán számára fontosabb az együttmüködés, hiszen ott olvashatunk több specifikus anyagot a kérdésről, azonban a kazah hírek részleteiben is egyértelmüen megfigyelhető a vízügyi együttműködés narratívája. Mindez megerősíti a folyamatkövető elemzésnél tapasztaltakat, miszerint a 
diskurzusok ebben az esetben a politikai-gazdasági-társadalmi kontextustól függetlenül alakítják a vízmegosztással összefüggő államközi kapcsolatokat.

\subsection{Az együttmüködés és konfliktus narratívái az állami hírügynökségek idegen nyelvü cikkeiben}

A fejezet második felében nem időszakonként, hanem az állami hírügynökségek 2010 után megjelent híreit felhasználva követem nyomon, hogy a vizsgált diádok esetében a határon átnyúló folyók témájához az együttmüködés vagy a konfliktus narratívája társul a vízmegosztással összefüggő államközi kapcsolatok tekintetében. Mindezzel az értekezés vége felé közeledve a történeti időszakok áttekintése után napjaink történéseiröl is képet kapunk, a következtetések levonása előtt a hírek vizsgálata révén nyilvánvalóvá válik, hogy milyen irányban haladnak tovább az előző fejezetekben áttekintett folyamatok a két állampár tagjai között.

A vizsgált médiumok kiválasztásánál arra törekedtem, hogy az állami hírügynökségek portáljait felhasználva azon cikkekben vizsgáljam meg az együttműködés és a konfliktus narratíváit, melyekben előfordul a Rogun és a Kambarata gátrendszerek neve. Mivel a közép-ázsiai állami hírügynökségek angolul és oroszul is közlik tartalmaikat, mindkét nyelven célszerü megvizsgálni a vízerömü-rendszerek nevének megjelenését. Ez a feltételrendszer erősen leszükítette az elérhető cikkek számát, így lehetségessé vált minden, a lenti keresőkifejezéseknek megfelelő cikk egyedi elemzése, illetve következtetések levonása nemcsak azok tartalmából, de azok mennyiségéből is. A vizsgált hírügynökségek és a Google-ban használt keresőkifejezések a következők:

1. Tádzsikisztán: Khovar hírügynökség (khovar.tj; keresőkifejezés: Rogun site:khovar.tj, Рогун site:khovar.tj);

2. Üzbegisztán: UzA hírügynökség (uza.uz; keresőkifejezés: Rogun site:uza.uz, Рогун site:uza.uz);

3. Kirgizisztán: Kabar hírügynökség (kabar.kg; keresőkifejezés: Kambarata site:kabar.kg; Камбарата site:kabar.kg);

4. Kazahsztán: Kazinform hírügynökség (keresőkifejezés: Kambarata site:inform.kz, Камбарата, Камбаратинской site:inform.kz).

A vizsgált cikkek nyelvét (angol/orosz) mindezek esetében a keresőmotor ,advanced search” opciói között állítottam be. Kiegészítésképpen a keresőmotoros keresések mellett a hírügynökségi portálok saját archívumában is rákerestem a „Rogun” és a 
„Kambarata” szavakra, mind az angol, mind az orosz nyelvü honlapon, és megvizsgáltam, hogy az így megjelenő találatok megerősítik-e a keresőmotoros keresés alapján levont következtetéseket. Ha eltérés volt a két adatbázis között, akkor a 2016ban megjelent cikkek vizsgálatát is bevontam az elemzésbe.

\subsubsection{A Tádzsikisztán-Üzbegisztán állampár és a Rogun gátrendszer narratívái}

A tádzsik állami hírügynökség, a Khovar hírportálján a keresőmotor 13 angol nyelvü cikket talált a „Rogun” keresőszóval, míg az orosz nyelvü „Рогун” keresőszóra hat találat érkezett. A honlap archívumában az angol nyelvű keresés négy találatot eredményezett, melyek mindegyike 2016-ban jelent meg. Orosz nyelvü cikkek tekintetében az archívumában számos szöveget tartalmaz Rogun témában (2016. augusztus 1-jén 745 találat, 2008-ig visszamenően), ezek közül kilenc a 2016-os évből származik.

Igen sokatmondó a téma jelentőségének tekintetében, hogy már a nyitólapon, a hírportáloknál megszokott fö tematikus fülek (külpolitika, gazdaság, kultúra, sport) között is megtalálható „A Rogun HPP Projekt értékelése.” A keresőmotor által kilistázott témák között az ezen fül alatt megtalálható dokumentumok, vagyis a Rogun gátrendszerről szóló jelentéseinek részletei dominálnak, a 13-ból hat találat a jelentés elemeinek szövegét rögzíti angol és orosz nyelven. A felsorolt anyagok között nemcsak a legismertebb Világbank-féle értékeléseket találhatjuk meg, hanem a Coyne et Bellier és a Poyry Energy Ltd. jelentéseit is, melyek szintén 2014-ben kerültek publikálásra. A nemzetközi értékelésekre fektetett nagy hangsúly mutatja, hogy Tádzsikisztán igyekszik annak a percepciónak a fenntartására, miszerint a Rogun vízerőmü-rendszer építkezései a nemzetközi elöírásoknak megfelelően, szabályosan zajlanak, az állam betartja a nemzetközi közösség szabályait, követi annak normáit (Khovar [2016a]).

Egy másik cikk (melyet a keresőmotor négy különböző formában listáz ki) Emomali Rahmon elnök 2015. júliusi látogatását írja le a Rogun gátrendszer munkálatainak megtekintésére. A cikk kitűnő, minőségi munkáról, lelkes munkásokról, tervszerü haladásról számol be, a munkálatok sikerességét Rahmon elnök közvetlen utasításainak tudva be. Az is kiderül, hogy a látogatás csupán egy a sok közül, melyek során az elnök vízerőmüvek állapotát ellenőrzi. Mindez nemcsak a Rogun gátrendszer, hanem a vízerőmüvek általános jelentőségét is hangsúlyozza. A cikk emellett azt is kiemeli, hogy a munkálatok a Világbank jelentésének megfelelően folynak. A szöveg két Rahmon-idézetet is tartalmaz, melyek jól illeszkednek a Rogun-rendszerről szóló 
korábban bemutatott diskurzushoz. Egyrészt nagy hangsúly esik az építkezések hatalmas jelentőségére a tádzsik nemzet számára: Rahmon szerint „az építkezés résztvevőinek tökéletesen tisztában kell lenniük azzal, hogy a Rogun vízerőmü-rendszer évszázadokra épül, és a munka minőségének meg kell felelnie ennek a rangos célkitűzésnek" (Khovar [2015]). Másrészt pedig a régió érdekei is megjelennek, a Rogun-rendszer ezeknek megfelelően jelenik meg az elnök mondataiban: „századokon keresztül szolgálnia kell a tádzsik népet és az egész régiót, csak előnyöket biztosítva, és semmilyen kárt nem okozva" (Khovar [2015]).

A honlap archívuma két olyan angol nyelvű cikket tartalmaz, ami nem jelent meg a keresőmotor találatai között. Ezek 2016 júliusában jelentek meg, és egy érdekes fejleményről, a 2015 februárjában a Rogun vízierőmü-rendszer építéséről szóló tender győztesének kihirdetéséről szólnak, mely a Salini Impregilo olasz vállalat lett. A szerződés szerint a vállalat 3,9 milliárd USD értékben fogja a Rogun-rendszert végleges formájában megtervezni és kivitelezni. A cikkekben ismételten hangsúlyosan megjelenik a nemzetközi követelmények betartásának szándéka, illetve a Világbank értékelésének átfogó jellege is bemutatásra kerül, utalva az értékelésbe bevont államok és szakértők széles körére, újfent kiemelve, hogy a Rogun-rendszer minden tekintetben megfelel a nemzetközi elvárásoknak. Ehhez a képhez járul hozzá a Salini Impregilo szakértelmének, tapasztalatának részletezése is (Khovar [2016b]). A tádzsik elnök találkozója a vállalat vezérigazgatójával külön cikket érdemelt a Khovar.tj-n, ami szintén illeszkedik ebbe a diskurzusba (Khovar [2016c]).

A hat orosz nyelvü keresőmotoros találat mindegyike a Rogun vízerőmürendszer értékeléseit rögzíti. Érdemes mindezt kiegészíteni a honlap archívumában található, 2016-ban megjelent orosz nyelvű cikkekkel. Ezek említése azért lehet érdekes, mert szintén a bemutatott diskurzust erősítik. A Világbank dokumentumai és a Salini Impregilo témájú cikkek már bemutatott narratíváját erősítik az amerikai szeizmológus David Simpsonnal folytatott interjún alapuló írások, melyekben nagy hangsúlyt kap Simpson véleménye arról, hogy a Rogun rendszer építése szeizmológiai szempontból biztonságos (Khovar [2016d]). A fennmaradó cikkek egyike a Rogun részvényeseinek éves üléséröl tudósít (Khovar [2016e]), míg egy másik üzleti statisztikákat ismertet (Khovar [2016f]). A legérdekesebb azonban közvetlenül érinti a tádzsik-üzbég kapcsolatokat: ebben a tádzsik állami vasutak vezetője ugyanis arról nyilatkozik, hogy a Rogun építési munkálatait nem akadályozza Üzbegisztán tevékenysége (Khovar [2016g]). 
A cikkek összességében jól mutatják a Rogun vízerömü-rendszer kiemelt fontosságát Tádzsikisztán számára. A szövegekben jelentős szerepet kap annak hangsúlyozása, hogy a tervek összhangban vannak a nemzetközi elvárásokkal, miközben a körülöttük kialakult vitákról nem esik szó, az Üzbegisztánnal való feszültségek nem jelennek meg sem explicit, sem implicit módon. A cikkek természetesként tüntetik fel az építkezések szükségességét, nemcsak az állam, de az egész régió számára is rendkívül előnyös projektként tüntetve fel a Rogun-rendszert.

Az üzbég állami hírügynökség, az UzA angol nyelvü hírportálja esetében az angol nyelvü „Rogun” kifejezésre 7, míg az orosz nyelvü „Рогун” kifejezésre 1 találat érkezett. A hírportál saját archívuma nem jelenített meg más találatokat angol nyelven, oroszul azonban 23 új találatot adott 2008 és 2014 között. 2016-os cikk viszont nem szerepelt az archívumban.

A hét, keresőmotor révén talált angol nyelvü cikk közül négy, illetve kettő azonos, tehát alapvetően három cikkben vizsgálható a konfliktus és az együttmüködés narratívája. Az első (UzA [2010]) egy 2010-ben Üzbegisztánban megrendezett konferenciát mutat be, melynek témája a határon átnyúló környezeti problémák kérdése volt a közép-ázsiai régióban. A konferencia bemutatása során fontos szerepet kap a nagyméretü vízerőmüvek építkezéseinek káros hatása a térségben. Ennek hangsúlyozásához a cikk nemzetközi környezettudatosság, a klímaváltozás és a fenntartható fejlődés diskurzusának kereteit alkalmazza, amivel, a tádzsik narratívához hasonlóan, a nemzetközi közösség normáinak és elveinek való megfelelést emeli ki. A cél azonban teljesen eltérő: az üzbég fél célja a Rogun és az ahhoz hasonló nagyszabású vízügyi projektek leállítása.

Ehhez a cikkíró a vízügyi racionalitás diskurzusát alkalmazza, gyakran felhívva a figyelmet az erőforrások szabályozott felhasználásának fontosságára. Mindez az Araltó katasztrófájának több alkalommal is felmerülő ellenpéldájával is kiegészül, méghozzá azzal kapcsolatban, hogy a nagyszabású, de felelőtlen és átgondolatlan építkezések, mint a Rogun-rendszer, ehhez hasonló környezeti válságokhoz vezethetnek, melyek nagy társadalmi és politikai visszhangot váltanak ki. Üzbegisztán ebben a diskurzusban úgy jelenik meg, mint a nemzetközi közösség ,jó tanulója.” A cikk sorra veszi az állam elért eredményeit a környezetvédelem és az egészségügy területein mind helyi, mind nemzetközi szinten, hangsúlyozva kötelezettségeinek folyamatos teljesítését. Emellett többször felhívja a figyelmet explicit és implicit módon arra, hogy a régióban legalább egy „rossz tanuló” is van, Tádzsikisztán, melynek irracionális és felelőtlen döntései az Aral-tóéhoz hasonló katasztrófát eredményezhetnek. 
Ebben az esetben is megfigyelhető, hogy a cikkíró külföldi szakértő autoritását vonja be az üzbég álláspont megindokolásába, többek között a „,szintén hegyvidéki Ausztriából érkezett” Manfred Tichy lapszerkesztő álláspontjára támaszkodva: „A Rogun vízerőmü-rendszer jó példája annak, amikor egy állam más államok számára káros elképzeléseket próbál megvalósítani. A 30-40 éves tervezet, ami a szovjet megalománia időszakában született, nem felel meg a környezeti és technológiai biztonság követelményeinek, ezért nem lenne szabad megépíteni [a vízerőmürendszert]" (UzA [2010]).

A második vizsgált cikk (UzA [2011a]) olyannyira ezen a vonalon halad tovább, egy 2011-es vízügyi konferencia tanulságait összegezve, hogy több mint három oldalon keresztül nemzetközi vízügyi szakértők Üzbegisztán álláspontját támogató véleményeit rögzíti, idézi. Ezek témái visszatérőek, és igen hasonlóak az előző cikkéihez: az Aral-tó katasztrófája, a Rogun megépítésének technológiai, környezeti és társadalmi veszélyei, az új hatástanulmány készítésének fontossága, illetve Üzbegisztán ,jó tanuló” volta és támogatást érdemlő szerepe mind-mind megjelennek. Ezek részletes áttekintése helyett érdemesebb Karimov elnök nyitóbeszédében elhangzott szavait idézni, melyek a legmagasabb szinten foglalják össze az üzbég álláspontot: ,a régió minden államának gazdasága hatalmas károkat fog szenvedni, ezrek élete kerül majd veszélybe. Ha ezeket a fenyegetéseket mérlegeljük, elmondhatjuk, hogy a Rogun öngyilkosságot jelent [a régió számára]. Mindezek miatt a kérdést objektíven, nagy körültekintéssel és alapossággal kell megvizsgálni nemzetközi szinten” (UzA [2011a]).

A harmadik vizsgált cikk (UzA [2011b]) ugyanennek a vízügyi konferenciának a tapasztalatait rögzíti, ezúttal a cikkíró saját szavaival. A fent említett témák folyamatos visszatérése mellett a hangsúly ezúttal is a nemzetközi részvételre és a nemzetközi közösség által elfogadott diskurzusok megerősítésére kerül. A cikk az üzbég álláspont legitimálására részletesen leírja a nemzetközi résztvevők körét: „32 országból érkezett több mint 350 szakértő, kiváló tudós, környezeti szakember és vízigazgatási specialista, illetve több mint 30 befolyásos nemzetközi szervezet és pénzügyi intézmény képviselői, beleértve az ENSZ-t és ügynökségeit, a Vízügyi Világtanácsot, a Globális Vízügyi Partnerséget, a Világbankot, az Ázsiai Fejlesztési Bankot, az Európai Gazdasági Bizottságot, az USAID-et [...], és még sok más szervezetet” (UzA [2011b]).

Az orosz nyelvű cikk a Rogun vízerőmü-rendszer építésének veszélyeit mutatja be részletesen, szintén egy 2011-es nemzetközi konferencia szakértőinek véleménye alapján. A hangsúly itt az építkezések különös kockázataira hívja fel a figyelmet, főként mérnöki szempontokból, beleértve ezekbe a szeizmikus tevékenységből fakadó 
veszélyeket, a földrengés, a földcsuszamlás, az áradások kérdését. Emellett a projekt alulfinanszírozottsága is felmerül, melynek alapján a szakértők rossz minőségü munkára számítanak - ami még inkább megnöveli a felsorolt kockázatokat. A cikk következtetése az előző szövegeket is számításba véve egyáltalán nem meglepő: a Rogun-projekt építkezéseit le kell állítani (UzA [2012]).

Összességében elmondható, hogy Üzbegisztán határozottan elkötelezett a Rogun vízerőmü-rendszer építkezéseinek leállítása, vagy legalább hátráltatása mellett. Ennek érdekében a cikkek több alkalommal hivatkoznak a nemzetközi közösség normáinak és elveinek betartatásának szükségességére, különösen a környezeti és a technológiai normák területén. Tádzsikisztán és a Rogun projekt egyértelmüen negatív példaként jelenik meg ezen a területen az üzbég diskurzusban. A cikkek, bár igyekeznek objektívek lenni, számos negatív értéktartalmú szót használnak fel a tádzsik vízügyi politika és a Rogun-projekt leírására. Mindezek egyértelműen a konfliktusos helyzet által dominált diskurzust rögzítenek a tádzsik-üzbég vízügyi kapcsolatokban.

A tádzsik és üzbég állami hírügynökségek megvizsgált cikkeinek alapján feltárt diskurzusokat egybevetve megfigyelhető, hogy két teljesen ellentétes álláspontot rögzítenek a Rogun vízerőmü-rendszer kérdésében, melyek megfeleltethetőek az összehasonlító folyamatkövetés és az etnográfiai módszer révén szerzett ismereteknek. A szövegek egyértelműen a nemzetközi közösségnek szánt képet mutatnak a két államról: mindkét fél több alkalommal hangsúlyozza, hogy tevékenységei és elképzelései megfelelnek a nemzetközi közösség normáinak, illetve implicit módon azt is, hogy ennek következtében megérdemlik a támogatást.

A nemzetközi közösséggel való együttmüködés tehát mindkét állam számára fontos (hiszen mindkét államnak érdeke, hogy nemzetközileg is jelentős szereppel, illetve anyagi forrásokkal vagy know-how-val rendelkező támogatókat találjon elképzeléseihez). A két állam közötti feszültségek, a konfliktus narratívája a tádzsik fél részéről nem jelent meg a cikkekben, az üzbég fél azonban mind explicit, mind implicit módon elítéli Tádzsikisztán tevékenységét és a Rogun vízerőmü-rendszer építését, nyíltan veszélyesnek tekintve azt az egész régió számára. A tádzsik fél szándéka eközben, hogy békés, együttműködő hatalomként feltüntetve magát (az utóbbi időben a cikkek alapján még Üzbegisztánnal szemben is), az egész régió számára hasznos projektként jelenítse meg a Rogun-projektet. Így, bár a konfliktus nem jelenik meg 
explicit módon mindkét állami hírügynökség cikkeiben, azok szövege alapján (és azok elhallgatásai alapján), illetve az állampár kapcsolatainak fentebbi elemzése révén szerzett háttértudásra is építve kimondható, hogy a vizsgált diskurzusok egyértelmüen konfliktust, feszültségeket és versengést rögzítenek a két állam között, melyben Tádzsikisztán engedékenyebb hangnemet üt meg, de mindenképpen ragaszkodik a Rogun vízerőmű-rendszer felépítéséhez, Üzbegisztán pedig teljes nyíltsággal képviseli álláspontját a projekt mielőbbi beszüntetésére vonatkozóan.

\subsubsection{A Kirgizisztán-Kazahsztán állampár és a Kambar-ata I. gátrendszer narratívái}

A kirgiz Kabar.kg állami hírportálon az angol nyelvü „Kambarata” keresésre a keresőmotor jelentős számú, 290 találatot listázott ki, amiből a honlapon jelenleg 47 elérhető, illetve 5 cikk jelent meg 2016-ban. Az orosz nyelvü keresésnél („Камбарата”) 51 találatot kaptam, amiből 34 elérhető a honlapon, és egy sem jelent meg 2016-ban. A találatok kiemelkedően magas száma azt mutatja, hogy Kirgizisztán számára kiemelten fontos a Kambar-ata I. vízerőmü-rendszer megépítése, illetve az, hogy annak fejleményeiről tájékoztassa a nemzetközi közösséget. A találatok magas száma miatt az elemzéshez a másik három államban megjelent cikkek számához és megjelenési idejéhez arányosítottam a kirgiz találatok számát, 2011-ig minden évböl kiemeltem egy angol nyelvü cikket, lehetőleg olyat, melyeknek már a címében szerepel a „Kambarata” szó. Emellett, az átfogó kép elemzése érdekében, a 2011 és 2016 között megjelent cikkek címeiből, témáiból is vontam le következtetéseket.

2011-ben egyetlen cikk jelent meg Kambar-ata I. témában, mely az orosz segítségnyújtásról szól a vízerőmü-rendszer megépítésében (Kabar [2011]). A 20112016 között (és különösen a 2015-ben) megjelent cikkek legjellemzőbb témája címeik alapján a kirgiz-orosz együttmüködés az építkezések során, ezért, bár nem kapcsolódik közvetlenül a kirgiz-kazah viszonyokhoz, érdemes áttekinteni a cikkekben megjelenő diskurzust. Az orosz-kirgiz együttmüködés a Kambar-ata I. megépítésére ugyanis 2016ban (a dolgok jelenlegi állása szerint) véglegesen megszünt. A kirgiz parlament 2016. január 20-án felbontotta az Oroszországgal kötött szerződést a Kambar-ata I. és a FelsőNarin vízerőmü-rendszereinek építésére, mivel Oroszország nem teljesítette 2015-ös vállalásait, és ezzel veszélybe sodorta a projektek kivitelezését. Az építkezéseket ezzel határozatlan időre felfüggesztették. Kirgizisztán számára így rendkívül fontos az új befektetők és támogatók bevonása. Ebben akár Kazahsztán is szerepet játszhat, egy 
másik elképzelhető szcenárió szerint azonban az orosz elhidegülés Asztana tartózkodását is maga után vonhatja (Kabar [2016]).

Tény, hogy a kirgiz-kazah együttmüködés diskurzusa 2016 elött egyértelmüen megjelenik a vizsgált cikkekben. 2012-ben például arról tudósítanak, hogy egy kazah szakértőkből álló munkacsoport érkezett Kirgizisztánba az együttmüködés feltételeinek megtárgyalására. A cikk azt is rögzíti, hogy Asztana a vízügyi kooperáció mellett az energiaügyekben is keresi a lehetőséget a közremüködésre (Kabar [2012a]). A Kabar.kg gyakran ír vízügyekkel kapcsolatos közép-ázsiai államközi találkozókról, tárgyalásokról, melyeknek az esetek nagy részében Kazahsztán ad otthont, ezzel is utalva Asztana hajlandóságára a vízügyi együttmüködés elősegítését illetően (Kabar $[2012 b])$.

A kazah együttmüködési törekvések ellenpontjaként az üzbég álláspont is megjelenik a cikkekben, melyek arról tudósítanak, hogy Karimov igyekszik megakadályozni a Kambar-ata I. projekt megvalósulását. Bár a cikkek objektív, semleges hangnemben tudósítanak mindkét állam álláspontjáról, Kazahsztánéhoz egyértelműen az együttmüködést, Üzbegisztánéhoz pedig a feszültségeket jelző jelentéstartalmak („nyomást gyakorol” (Kabar [2013a]); „ezek a kérdések bonyolíthatják a kirgiz-üzbég kapcsolatokat” (Kabar [2013b])) kapcsolódnak. Egy 2013-es cikkben Atambajev elnök idézett szavaiból is egyértelműen látható a különbség az alapvetően ellenséges Üzbegisztán, és a viszonylag barátságos Kazahsztán között. Ebben az elnök így nyilatkozik: „Üzbegisztánnak meg kell értenie, hogy a [Kambar-ata I.] projekt végrehajtása az ő érdekeit is szolgálja. Kazahsztán ezt már megtette" (Kabar [2013c]). Ugyanez derül ki egy 2014-es interjúból is, melyben kirgiz elnök amellett érvel, hogy a Kambar-ata I. projekt „egyedülálló és nagyon szükséges, nemcsak Kirgizisztán, hanem szomszédai, Üzbegisztán és Kazahsztán számára,” a két államot egyformán említve. A folytatásban azonban külön kitér arra, hogy reméli, „Üzbegisztán is megérti ezt majd valahogyan" (Kabar [2014a]). Ezzel explicit módon utal a feszültségekre, illetve azt is implikálja, hogy Kazahsztán esetében nincs probléma a Kambar-ata I. projekttel kapcsolatban. Atambajev nyilatkozatai kapcsán megjelenik a Tádzsikisztán és a Rogun esetében számos alkalommal látható diskurzus azzal kapcsolatban, hogy a projekt az egész térség számára előnyös lesz. A Kabar.kg azonban nem érzi szükségét annak, hogy részletesen, többször igyekezzen ezt bizonygatni, ami implicit módon szintén utal arra, hogy a legjelentősebb és leginkább érintett szomszédos állam nem ellenzi a projekt megvalósítását. 
Az orosz nyelvü cikkek tekintetében látható, hogy számos cikk tükörfordítása az angolul megjelenteknek. Emiatt még szembetünőbb, hogy 2016-ban nem jelent meg a „Камбарата” kifejezés a Kabar.kg-n, ami nyilvánvalóan az együttmüködés felbomlásának tudható be. A korábbi cikkek esetében jellemző, hogy a csak oroszul megjelentek a kirgiz-orosz kapcsolatról szólnak, mint például a „Kirgizisztán mindig is Oroszország megbízható és stabil partnere volt, és az is marad” címmel megjelent, viszonylag nagyobb lélegzetű áttekintés, (Kabar [2015c]) vagy a posztszovjet gazdasági integrációval kapcsolatosak (Kabar [2015d]). Megfigyelhető még, hogy a csak orosz nyelven megjelent cikkek általában nagyobb terjedelmüek, a Kambar-ata I. vízerőmürendszerről is olvashatóak nagyobb lélegzetü értékelések (Kabar [2014b]). Összességében a csak orosz nyelven megjelent cikkekből nem derül ki új információ a kazah kapcsolat tekintetében, azonban a fent elemzett cikkek (mint például a két Atambajev-beszédet idéző) többsége orosz nyelven is megjelent. Összességében tehát elmondható, hogy az orosz nyelven megjelent cikkek azonos diskurzust rögzítenek a Kirgizisztán-Kazahsztán kapcsolatokat illetően, mégpedig azt, hogy Kazahsztán egyértelműen együttműködő félnek tekinthető a Kambar-ata I.-projektben.

Ezt a kazah állami hírügynökség honlapján megjelenő cikkek is alátámasztják. Az Inform.kz 8 találatot adott az angol nyelvü keresésre a „Kambarata” kulcsszó esetében, míg az orosz nyelvű „Камбарата” kifejezés 10-szer fordult elő. A honlap belső archívumában ezek közül egy-egy elérhető, mindkettő 2012-ben jelent meg. A nyolc angol nyelvü találatból hat ugyanarra a cikkre mutat, ez azonban egyértelmüen az általam vizsgált jelentéstartalmakat rögzíti. A cikk ugyanis a Kirgizisztán által Kazahsztánnak felajánlott együttműködési lehetőséggel foglalkozik a Kambar-ata I. vízerőműrendszer építkezéseinek kapcsán, ami további energiaügyi együttműködési lehetőségekkel is kiegészült (Kazinform [2012a]). (Ez az esemény egyébként a kirgiz tudósítások között is megjelent, mind angol, mind orosz nyelven). A honlapon elérhető orosz nyelvű cikk, illetve a tíz keresőmotoros orosz nyelvű cikk közül hét ennek tükörfordítása, új tartalmakat nem emel be a szövegbe (Kazinform [2012b]).

A fennmaradó két angol nyelvű cikk egyike egy száraz leírás Kirgizisztánnak a posztszovjet gazdasági integrációhoz való csatlakozási tárgyalásairól, a másik azonban megerősíti az együttmüködés diskurzusát. A cikk Nazarbajev kazah és Karimov üzbég elnök közös fellépését rögzíti annak érdekében, hogy a térség vízenergia-forrásainak kiaknázása, vagyis az új vízerőmü-rendszerek építése nemzetközi szakértők közremüködésével menjen végbe. Annak ellenére, hogy az üzbég elnök neve is említésre kerül a cikkben (ami Karimov alapvetően feszültségeket keltő álláspontja 
miatt nem az együttmüködés jelentéstartalmát idézi fel), a szöveg Nazarbajev érvelésén keresztül Kazahsztán jóindulatú álláspontját és retorikáját rögzíti a kérdésben. A kazah elnök véleménye az, hogy a régió egészének érdeke a nemzetközi közremüködés a technológiai és a környezeti károk elkerülése végett, illetve a vízmegosztás megfelelő szabályozása érdekében. Az elnök idézett szavaiban „kölcsönösen elönyös mechanizmusok" kialakítását sürgeti. A kirgiz vezetésről (mely a cikk megjelenésének idején Kurmanbek Bakijev elnöksége alatt müködött) úgy véli, hogy készen áll az együttmüködésre, és megérti az előzetes hatástanulmányok szükségességét. Nazarbajev egyértelműen az erősebb fél retorikáját alkalmazza, és az is egyértelmü, hogy saját elképzeléseinek követésére szólítja fel Kirgizisztánt. Mindezt azonban egy jóindulatú szereplőként teszi, a felszólítás burkolt, viszonylag barátságos, beleillik a korábban ismertetett „,nagy testvér” szerepébe. Ezt mutatja az is, hogy a kazah elnök „megértését” fejezi ki a kirgiz gazdasági helyzettel szemben - bár ennek ellenére elvárja elképzeléseinek teljesítését. A hivatkozási alap emellett a régió egészének jóléte, ami egy bizonyos közösséget tételez fel a közép-ázsiai államok között, ezzel is tompítva a felszólítás élét (Kazinform [2010]).

A fennmaradó három orosz nyelvü cikk közül egy tekinthető valóban relevánsnak témánk szempontjából. Ez ugyanazt a narratívát rögzíti, amit a fent részletesen ismertetett angol nyelvü cikk, vagyis a külföldi szakértők bevonása mellett érvelő kazah és üzbég elnök álláspontját mutatja be. Az előző cikk 2010 márciusában, míg ez ugyanazon év szeptemberében, egy fél év eltéréssel jelent meg, és, bár egy igen hasonló eseményről szól, hangsúlyai és hangneme nagymértékben eltér attól. Ez a cikk ugyanis Iszlam Karimov álláspontjáról szól, Nazarbajevet csak megemlítve a tárgyalások résztvevőjeként. Az üzbég elnök párhuzamot von a Rogun és a Kambar-ata rendszerek között, és megállapítja, hogy a körülmények megváltoztak a két vízerőmürendszer megtervezése óta, így elengedhetetlen a hatástanulmányok újraírása nemzetközi szakértők bevonásával. Emellett annak vizsgálata is szükséges véleménye szerint, hogy hogyan befolyásolja ezek megépítése a közép-ázsiai államok közötti vízmegosztás rendszerét. Ezen cikk fó hozzáadott értéke a diskurzuselemzés szempontjából az, hogy ellenpontot képez az előzővel, megerősítve azon érvelésemet, hogy Nazarbajev véleménye és hangneme barátságosnak tekinthető, és az együttmüködésre helyezi a hangsúlyt. A Karimov álláspontját bemutató cikk ezzel szemben semleges hangnemet rögzít, az együttmüködés gondolata pedig teljes mértékben hiányzik a bemutatott álláspontból. Az üzbég elnök objektív szükségszerüségre hivatkozik, amikor a nemzetközi szakértők bevonása mellett érvel, 
továbbá a szövegben nem esik szó a kirgiz gazdasági nehézségekről vagy a kirgiz vezetés hajlandóságáról az üzbég elképzelések teljesítésére (Kazinform [2012c]).

Összefoglalásképpen elmondható, hogy a Kambar-ata I. témájú cikkek száma igen alacsony a kazah hírügynökség oldalán. Ez egyrészt azt mutatja, hogy az ügy kevés érdeklődésre tart számot, tehát nagy valószínüséggel nem terhelt feszültségekkel, másrészt pedig azt, hogy Kazahsztán számára Kirgizisztán nem tekinthető kiemelt partnernek. A kevés megjelent cikk azonban jóindulatú, barátságos viszonyt rögzít a két állam között, amelyben a kazah fél valamelyest leereszkedően, de hajlandó az együttmüködésre, hangsúlyozva a „nagy testvér” szerepét, ami a két állam közötti általános külpolitikai kapcsolatokban is jellemzö.

A kirgiz és a kazah állami hírügynökségek hivatalos oldalain megjelent cikkek alapján a Kambar-ata I. vízerőmü-rendszer kérdése egyértelmüen a kirgiz félnek fontosabb, a megjelent tudósítások alapján a kazah fél nem túlzottan érdeklődő. Ezzel együtt is tisztán látható azonban a releváns cikkek áttekintése után, hogy a két állam hasonló álláspontot képvisel a Kambar-ata I. vízerőmü-rendszer megépítése kapcsán, illetve az egymás közötti vízmegosztással összefüggő kapcsolatok területén - ez pedig az együttmüködés folytatása.

A vizsgált cikkekben három tendencia utal arra, hogy a kirgiz-kazah viszony diskurzusában a mérsékelt együttmüködés jelentéstartalma a domináns a Kambar-ata I. vízerőmü-rendszerrel kapcsolatosan. Az első (és legkézenfekvőbb) a kazah segítségnyújtás, közreműködés motívumának megjelenése a cikkekben. Bár nem sok ilyen jellegü tudósítás jelent meg, a meglévőkben egyértelmü ez a megközelítés. A második tendencia az üzbég és a kazah álláspont összehasonlítása, mely mind kirgiz, mind kazah oldalon ellentétbe állítja Karimov erőszakos, feszültségekkel terhelt követeléseit a munkálatok beszüntetésére, illetve Nazarbajev jóindulatúnak tekinthető hangnemét. A harmadik tendencia kevésbé direkt, ebben az esetben a feszültséget mutató tényezők megjelenésének teljes hiányából, illetve a kirgiz fél kiemelt érdeklődésének és a kazah fél érdektelenségének nagy különbségéből vonható le az a következtetés, hogy a két állam közötti kapcsolatban nem jellemzőek a feszültségek a vízügyek területén. Ez önmagában nem feltétlenül utalna az együttműködés domináns diskurzusára a két állam között, az előzőekkel egybevetve azonban alátámasztja azok következtetéseit. 


\section{4. Összegzés}

Az értekezés hatodik fejezete a diskurzuselemzés módszerét alkalmazta annak vizsgálatára, hogy a biztonságpercepciókat formáló diskurzusok domináns alakváltozatai hogyan követhetőek nyomon a nemzetközi közönségnek szánt szövegekben. A fejezet első részében többféle forrás áttekintő elemzését folytattam le, míg a fejezet második részében csak közép-ázsiai állami hírügynökségek híreit vizsgáltam meg, sokkal mélyrehatóbban és részletesebben.

Bár a közép-ázsiai állami hírügynökségek nem kielégítő és egymástól is nagyban eltérő honlapkezelési és archiválási módszerei meglehetősen megnehezítették a tudományos standardoknak megfelelő diskurzuselemzés végrehajtását, a megadott részletes feltételrendszer segítségével sikerrel végeztem el a kutatást, melynek legfontosabb eredménye az, hogy a vizsgált cikkekben valóban következetesen nyomon követhető a biztonságpercepciókat formáló domináns vízmegosztási diskurzusok jelenléte és változásai, melyek révén alapvetően az értekezés eddigi eredményeit megerősítő következtetések vonhatók le.

A nemzetközi jogi dokumentumok, a tudományos források és a hírek rövid elemzését a folyamatkövető elemzésnek megfeleltethető időszakokban végeztem el, aminek révén megerősítettem annak következtetéseit. A szovjet időszakban valóban az együttmüködést jelölő jelentéstartalmak vannak többségben a vizsgált anyagokban. A nemzetközi jogi dokumentumok szövegei mellett a tartalomból következő gyakorlati rendelkezések is egyértelműen ebbe az irányba mutatnak. A tudományos források és a hírek esetében ezek a narratívák azon szövegekben is megjelennek, melyekben a cikk szerzője (legyen nyugati vagy közép-ázsiai) általánosságban véve elítéli a szovjet módszereket, illetve a szovjet politikai rendszert, elfogadottságuk tehát igen széleskörünek mondható. Az 1990-es években a vízügyi rezsim létrehozásának dokumentumai igen részletesen rögzítették a korszakra jellemző domináns vízmegosztási diskurzusokat az államközi kapcsolatokban, így ezek elemzése fontos szerepet játszott feltételezésem bizonyításában, megerősítve a tudományos források és online hírek vizsgálatával nyerhető következtetéseket. A 2000-es évek tekintetében az online hírek voltak a legárulkodóbbak a diskurzus átalakulásának tekintetében, a vízmegosztáshoz társuló konfliktusos jelentéstartalmak itt jelentek meg a legélénkebben. Az új nemzetközi jogi dokumentumok hiánya, illetve a már létező megállapodások be nem tartása egyértelmüen megerősítette, hogy megváltoztak a narratívák. 
A fejezet második felének célja kettős volt: a diskurzuselemzésen túl napjaink helyzetébe is betekintést kívánt adni. A 2010-et követöen megjelent online hírek elemzéséből azt a tendenciát lehet megfigyelni, hogy Üzbegisztán és Tádzsikisztán esetében a konfliktusos jelentéstartalmak társítása és az ellenségesség narratívája alapvetően jellemző maradt a vízmegosztás területén, bár Tádzsikisztán igyekszik azt a képet kialakítani a Rogun-projektről, hogy minden a legnagyobb rendben zajlik. Kirgizisztán és Kazahsztán között eközben „testvéri” együttmüködés zajlik, a barátságosság narratívájában, de az idősebb és a fiatalabb testvér egyenlőtlenségének diskurzusában. A hírek áttekintése azt is megmutatta, hogy a 2012 körüli időszakban kifejezetten fontos kérdés volt mindkét diádban a vízerőmü-rendszerek kiépítése, majd 2016-ig valamelyest visszaesett az ezekről tudósító cikkek száma. 2016 viszont új eseményeket hozott mind a Rogun, mind a Kambar-ata I. kapcsán; az előző esetben a Világbank jelentése nyomán új lendülettel folytatódó építkezések miatt, a második esetben pedig az orosz-kirgiz szerződés felbontása miatt. Az új tendenciák azonban mindezidáig nem hoztak új jelentéstartalmakat, a tádzsik-üzbég diádban továbbra is a konfliktus, a kirgiz-kazah diádban pedig az együttmüködés dominál. Az állami hírügynökségek 2010 utáni híreinek vizsgálata tehát összességében nem mutat nagy változást, hangsúlyeltolódást a korábbi, 2000-es évtizedhez képest, és a diskurzuselemzés első, áttekintő szakaszához hasonlóan, megerősíti a folyamatkövető elemzés, valamint az etnográfiai módszer révén levont következtetéseket. 


\section{ÖSSZEFOGLALÁS, KÖVETKEZTETÉSEK}

\section{1. Összefoglalás}

A hipotézisek részletes bizonyítása és a következtetések levonása elött a következőkben röviden összegzem az értekezés menetét. A téma indoklását és a módszertani alapvetéseket áttekintő első fejezetet követően értekezésem második fejezetének célja az volt, hogy bemutassa és elemezze a nemzetközi kapcsolatok elméletének vízügyekkel foglalkozó területeit. A jelenlegi helyzetet gyakorlati szempontból összegző 2.1. alfejezet bemutatta, hogy a népességnövekedés, az emberiség életmódjának átalakulása, a nem hatékony vízfelhasználás, a vízszennyezés, valamint a klímaváltozás hatásai azt eredményezhetik, hogy a vízbiztonság a XXI. század legfontosabb kihívásává válik a nemzetközi kapcsolatokban. Emiatt is szükséges, hogy a nemzetközi kapcsolatok elméletében kialakuljon egy olyan keretrendszer, amely hitelesen képes vizsgálni a vízügyi kérdéseket, vagyis, szükebben értelmezve, a vízmegosztás és a vízbiztonság kérdéseit.

Ezen keretrendszer kezdeményeinek kialakulását az értekezés 2.2. alfejezetében tekintettem át, hangsúlyozva, hogy az elméleti igényességü tudományos források igen ritkák ebben a témában. A 2.3. alfejezet e ritka források két fó elméleti irányvonalának, a neorealista neo-malthusiánus és a neoliberális bőségszaru-megközelítésnek a hidropolitikával kapcsolatos alapvetéseit tekintette át, a 2.3.3. szakaszban kitérve ezek kritikájára is. A neo-malthusiánus és a bőségszaru-megközelítés elméleti alapjainak áttekintése, ezek gyakorlati alkalmazásának példái, illetve az elméletek kritikái révén bizonyítottam első alhipotézisemet, miszerint a vízmegosztással összefüggő államközi kapcsolatok változatosságát a materialista és statikus irányultságú racionalista elméletek (neorealizmus, neoliberalizmus) nem képesek mélyrehatóan vizsgálni.

A 2.4. alfejezet fó célja a konstruktivizmus mint alternatív megközelítés bemutatása volt, ahol amellett érveltem, hogy ez az elméleti keretrendszer jelentős hozzáadott értékkel rendelkezik a vízügyi, vízmegosztási és vízbiztonsági kérdések tekintetében. Mindennek bizonyítására áttekintettem a konstruktivizmus általános ontológiai, episztemológiai és módszertani jellegzetességeit, a konvencionális konstruktivizmust jelölve meg vizsgálódásaim fő keretéül, majd a hidropolitika specifikus kontextusában is megvizsgáltam az elméleti keret alkalmazhatóságát, 
bizonyítva annak hozzáadott értékét. A konstruktivizmus metaelméleti keretének közvetítésére középszintű elméletek lehetnek szükségesek és célravezetőek, melyek közül a koppenhágai iskola három fö elgondolását emeltem ki a 2.4.3. és 2.4.4. alfejezetben. Ezek áttekintése megmutatta, hogy mind a szektorelmélet, mind a biztonságiasítás elmélete, mind pedig a regionális biztonsági komplexumok elmélete (illetve annak továbbfejlesztett formája, a hidropolitikai biztonsági komplexumok elmélete) hozzáadott értékkel bír a vízmegosztással összefüggő államközi kapcsolatok vizsgálatában. Mindezzel elméleti síkon már bizonyítottam értekezésem második alhipotézisét, miszerint a neorealizmus és a neoliberalizmus hiányosságainak kiküszöbölésére a konstruktivizmus megfelelő alapvetéseket és eszköztárat kínál a vízmegosztással összefüggő államközi kapcsolatok változatosságának vizsgálatára.

Az elméleti következtetések levonása mellett azonban feltétlenül szükségesnek találtam mindezt egy gyakorlati esettanulmány elemzésén keresztül is bizonyítani, melyhez a közép-ázsiai hidropolitikai biztonsági komplexum két állampárját, a Tádzsikisztán-Üzbegisztán és a Kirgizisztán-Kazahsztán közötti vízmegosztási kapcsolatok esetét használtam fel. Értekezésem 3. fejezetében egyrészt részletesen bemutattam a térséget és államait, valamint a barátságosság és ellenségesség dimenzióinak két ,állatorvosi lovát”, a Rogun és a Kambar-ata I. vízerőmürendszereket, utóbbit kiegészítve a Csu-Talasz vízgyüjtő területén kialakult kirgiz-kazah együttműködés bemutatásával. Másrészt áttekintettem a vízmegosztással összefüggő államközi kapcsolatokat materiális szinten befolyásoló hidrológiai kontextust, harmadrészt pedig bizonyítottam, hogy a régió valóban regionális/hidropolitikai biztonsági komplexumnak tekinthető.

Az értekezés következő három fejezetét egy-egy tipikusan konstruktivista módszertan bemutatásának szenteltem, melyek lehetőséget nyújtottak harmadik alhipotézisem bizonyításához is, miszerint a kialakuló vízbiztonsági diskurzusok egyrészt közvetítőként kapcsolódnak a politikai-gazdasági-társadalmi kontextushoz, másrészt önálló dinamikájuk révén független változóként is megjelenhetnek. Az etnográfiai módszer segítségével a politikai-gazdasági-társadalmi kontextust vizsgáltam meg, illetve az annak alapján kialakuló vízügyi és vízmegosztási diskurzusokat, melyek nagy hatással vannak az államközi kapcsolatok alakulására. Mindezt három példa segítségével valósítottam meg: az öntözéses gazdálkodás, a szovjet „civilizációs misszió" monumentális vízügyi építkezései, illetve a Szovjetunió felbomlása utáni állam- és nemzetépítési törekvések vizsgálatával. A folyamatkövető elemzés módszerét összekapcsoltam a szektorelmélet és a biztonságiasítás elméletének alkalmazásával, és 
három különböző időszakban (1960-1991; 1991-1999; 2000-2010) vizsgáltam meg a politikai-gazdasági-társadalmi kontextust, a vízmegosztási diskurzusokat, illetve az államközi kapcsolatok alakulását. Mindezek között egyértelmü kapcsolatot találtam, és a kirgiz-kazah diád példája segítségével azt is sikerült igazolnom, hogy a diskurzusok a kontextust közvetítő szerepükön túl független változóként is megjelenhetnek az államközi kapcsolatok alakításában. A harmadik konstruktivista módszer, a diskurzuselemzés alkalmazásával kapcsolatban célkitűzésem az volt, hogy közvetlenül megfigyeljem a vízmegosztással összefüggő diskurzusokat a két állampár államainak esetében, ennek segítségével tesztelve eddigi következtetéseimet, illetve kiegészítve azokat. A 6.1. alfejezetben különböző forrástípusok áttekintő elemzését végeztem el a folyamatkövető elemzésnek megfelelő időszakokban, melyek a diskurzusok közvetlen vizsgálatát követően megerősítették annak eredményeit. A 6.2. alfejezetben 2010 és 2016 közötti híranyagokat vizsgálva mutattam be a konfliktus és együttmüködés narratíváinak továbbélését a közép-ázsiai hidropolitkai komplexumban. Harmadik alhipotézisem így a három konstruktivista módszertan alkalmazásával bizonyítást nyert, a módszertanok eredményei pedig hozzájárultak első és második alhipotézisem gyakorlati megerösítéséhez.

Negyedik alhipotézisem (miszerint a vízmegosztással összefüggő államközi kapcsolatok a vízbiztonsági diskurzusok változásai által befolyásolhatóak és alakíthatóak, tehát alapvető kiindulópontjukban különböznek a materialista és statikus irányultságú elméletektől, sokoldalú eszköztárat kínálva nemcsak a vízmegosztással összefüggő államközi kapcsolatok változatosságának elemzésére, hanem a felmerülő krízishelyzetek kezelésére, enyhítésére, megoldására is) mindezek révén szintén bizonyítást nyert az elmélet szintjén, amit értekezésem 7. fejezetének 3., záró alfejezetében összegzek. A gyakorlati bizonyítás azonban már a kutatás további feladatai közé tartozik.

\subsection{Az értekezés eredményei és a kutatás további irányai}

Mindezek alapján a következő módon igazoltam hipotéziseimet:

H1: A vízmegosztással összefüggő államközi kapcsolatok változatosságát a materialista és statikus irányultságú racionalista elméletek (neorealizmus, neoliberalizmus) nem képesek mélyrehatóan vizsgálni. 
Bizonyítás: A neorealizmus és a neoliberalizmus 1) a materiális tényezőket tekinti elsődlegesnek az ideák világával szemben. 2) a természettudományokhoz hasonló módszerekkel vizsgálódik, pozitivista és kvantitatív megközelítéseket alkalmaz. 3 ) nem tekinti vizsgálatai prioritásának az identitások, normák, értékek szerepét. 4) gyakran elhanyagolja a kontextus szerepét a nemzetközi kérdések elemzése során, különösen a társadalmi, a nyelvi és a kulturális kontextus esetében. 5) általános, időtől és tértől független törvényszerüségeket igyekszik leírni, feltételezései gyakran determinisztikusak. Mindez számottevő korlátokat jelent a racionalista elméletek számára, különösen a társadalmi törvényszerüségek természeti törvényszerüségektől való eltérései esetében, mint például az identitás, a normák, az értékek, a kultúra vagy a nyelv vizsgálatában, a társadalmi változások dinamikája mögött álló folyamatok megértésében, vagy a hatalmi viszonyok leírásában, melyek kulcsfontosságúak lehetnek a vízügyekkel összefüggő államközi kapcsolatok alakulásának megértésében.

Az a tény, hogy első alhipotézisem bizonyítást nyert, nem jelenti azt, hogy értekezésem értéktelennek tekinti a racionalista elméleteket a vízmegosztással összefüggő államközi kapcsolatok vizsgálatában (ahogyan a 2.3.1. és 2.3.2. alfejezet is bemutatta), hiszen a hidropolitikai elméleti megközelítéseinek rövid történetében számos értékes elemzést alkottak, számos jelentős tendenciára hívták fel a figyelmet, sőt, a vízügyi feszültségek csökkentéséhez is hozzájárulhattak. Érvelésem szerint azonban a konstruktivizmus a racionalista elméletekkel szemben jelentős hozzáadott értékkel rendelkezik a vízmegosztással összefüggő államközi kapcsolatok vizsgálatában.

H2: A neorealizmus és a neoliberalizmus hiányosságainak kiküszöbölésére a konstruktivizmus megfelelő alapvetéseket és eszköztárat kínál a vízmegosztással összefüggő államközi kapcsolatok változatosságának vizsgálatára.

Bizonyítás: Az elméleti áttekintés alapján levonható a következtetés, hogy a konstruktivizmus 1) teret enged a változás elemzésének a vízügyi konfliktusok és együttmüködések vizsgálatában. 2) A vízügyi konfliktusok és együttmüködések kialakulásának magyarázatában egyaránt számításba veszi a materiális és szellemi eredetü tényezőket, egységként, kölcsönhatásban értelmezve azokat. 3) Képes arra, hogy a hagyományos racionalista elméletek által alapfogalmakként tekintett fogalmakat (mint például a vízszükösség) elemeire bontsa, és feltárja a hátterükben rejlő mechanizmusokat. 4) A hagyományos racionalista elméletek szűken értelmezett 
világképéhez képest új elemek vizsgálatát teszi lehetővé, melyek kiszélesítik az elemzés horizontját, és új magyarázó tényezők bevonását eredményezik (kultúra, nyelv), a kontextus feltárása révén is segítve a valóság mélyebb megértését. A három konstruktivista módszertani eszköz (az etnográfia, a folyamatkövető elemzés és a diskurzuselemzés) által feltárt összefüggések hagyományos racionalista eszközökkel azok ontológiai, episztemológiai és módszertani korlátai miatt nem tárhatóak fel teljes egészükben, ami a gyakorlati alkalmazás szempontjából is bizonyítja a konstruktivizmus hozzáadott értékét a vízmegosztással összefüggő államközi kapcsolatok elemzésében.

H3: A kialakuló vízbiztonsági diskurzusok egyrészt közvetítőként kapcsolódnak a politikai-gazdasági-társadalmi kontextushoz, másrészt önálló dinamikájuk révén független változóként is megjelenhetnek.

Bizonyítás: A politikai-gazdasági-társadalmi kontextust közvetítő, illetve független változóként ható diskurzusok szerepe a vízmegosztással összefüggő államközi kapcsolatok alakításában egyértelmü bizonyítást nyer az általam felhasznált három konstruktivista módszer triangulációjával. Az etnográfiai módszer bemutatta a politikaigazdasági-társadalmi kontextust közvetítő diskurzusok erejét a közép-ázsiai öntözéses gazdálkodásra épülő társadalmakban, a szovjet „civilizációs misszió” idejében, illetve a függetlenség elnyerése után. A folyamatkövető elemzés egyrészt alátámasztotta az utóbbi két időszakban tapasztalhatóakat, a 2000-es évtized vizsgálata pedig a kirgizkazah példa révén olyan esetet is bemutatott, amikor nem a kontextus, hanem a diskurzus közvetlen hatása révén alakultak a vízmegosztással összefüggő államközi kapcsolatok. A diskurzuselemzés eredményei szintén megerősítették az előző két módszer esetében tapasztaltakat. A gyakorlatban megfigyelhető jelenségek tehát megerősítik elméleti alhipotézisemet.

H4: A vízmegosztással összefüggő államközi kapcsolatok a vízbiztonsági diskurzusok változásai által befolyásolhatóak és alakíthatóak, tehát alapvető kiindulópontjukban különböznek a materialista és statikus irányultságú elméletektől, sokoldalú eszköztárat kínálva nemcsak a vízmegosztással összefüggő államközi kapcsolatok változatosságának elemzésére, hanem a felmerülő krízishelyzetek kezelésére, enyhítésére, megoldására is. 
Bizonyítás: A materialista és statikus irányultságú racionalista elméletek korlátait már bizonyítottam, illetve a konstruktivizmus hozzáadott értékénél már esett szó a változás elemzésbe való bevonásának fontosságáról. Negyedik alhipotézisem ezt a kiindulópontot hangsúlyozza (mely tulajdonképpen már első és második alhipotézisemben bizonyítást nyert), azonban az eddigi elméleti feltételezések helyett elmozdul a gyakorlat irányába is, azt feltételezve, hogy a konstruktivista elméleti keret alkalmazása a középszintü elméletek segítségével hozzájárulhat a vízmegosztással összefüggő államközi kapcsolatok problémáinak kezeléséhez, a valós megoldási lehetőségek feltérképezéséhez és gyakorlati alkalmazásához, ezzel elősegítve a döntéshozók munkáját. Az értekezés összessége elméleti szinten bizonyítja ezt az állítást, gyakorlati szempontból azonban mindez meghaladja az értekezés korlátait. A negyedik alhipotézis teljeskörü bizonyítása így a kutatás további feladatai közé tartozik, amihez a 7.3. alfejezetben felvázolok egy lehetséges szcenáriót.

A három alhipotézis teljes, illetve a negyedik alhipotézis részleges bizonyítása révén bizonyítottnak tekintem az értekezés fö hipotézisét, miszerint a vízmegosztással összefüggö államközi kapcsolatok változásait a hidrológiai és a politikai-gazdaságitársadalmi kontextus változásait közvetítő, de egyúttal sok esetben önálló dinamikával is rendelkezö vízbiztonsági diskurzusok alakitják, ezért a statikus hidropolitikai elméletekkel szemben a konstruktivista megközelités egyértelmü hozzáadott értékkel rendelkezik ezek vizsgálatában.

Az értekezés újdonságai mindezek alapján pontokba foglalva a következőek:

- Az értekezés a földrajz, a hidrológia, a hidropolitika, az etnográfia, a nemzetközi jog, a biztonságpolitika és a történelem tudományterületeinek összekapcsolásával, valóban inter- és multidiszciplináris módon vizsgálja a vízmegosztással összefüggő államközi kapcsolatok alakulását.

- Az értekezés magyar nyelven foglalja össze a hidropolitikai diskurzus fejlődésének főbb állomásait, amire korábban nem volt példa, sőt, angolul is ritka a részletes, tudományos igényü áttekintés.

- Az értekezés maga is jelentős hozzájárulást tesz a hidropolitika teoretizálási folyamatához. Mint az értekezés elején bemutattam, ez egy jelenleg is zajló folyamat, melynek nagy jelentőségét a gyakorlatban történő események (növekvő vízszűkösség, vízügyi feszültségek és együttműködések változásai) is alátámasztják. 
- Az értekezés hipotéziseinek bizonyítása révén bizonyítja a konstruktivizmus elméleti keretének hozzáadott értékét a racionalista elméletekkel szemben a vízmegosztással összefüggő államközi kapcsolatok értelmezésében és elemzésében.

- Az értekezés megvalósítja a Frédéric Julien [2012] által elméletben felvázolt elképzelést, melyben a koppenhágai iskola biztonságiasítás-elméleti keretének a vízmegosztással összefüggő államközi kapcsolatokra való alkalmazását javasolta.

- Az értekezés alkalmazza a hidropolitikai biztonsági komplexumok fogalmát, és felhasználja azt érvelésének megerősítésére.

- Az értekezés a biztonságiatlanítás elméleti keretére építi gyakorlati megoldási javaslatát, mely a jövőben konkrét policy-jellegü javaslatok alapját képezheti.

- Az értekezés három (Magyarországon egyébként a nemzetközi kapcsolatok vizsgálatában nem túl gyakran alkalmazott) konstruktivista módszer triangulációjára épül, melyet egy esettanulmányon alkalmaz. Ennek révén az így elért három következtetés megerősítheti vagy cáfolhatja egymást, amivel az értekezés egy meggyőző, mégis ritkán használt bizonyítási módszert mutat be.

- Az értekezés fejleszti a nemzetközi kapcsolatok elméletének magyar szókincsét, mind a koppenhágai iskola, mind a bemutatott három módszer (etnográfiai módszer, folyamatkövető elemzés, diskurzuselemzés) nyelvezetét illetően.

Jelen értekezés emellett, egy nagyobb kutatási folyamat első lépcsőjeként, több új kutatási irány felé nyitja meg az utat, melyek számos módon hozzájárulhatnak a vízmegosztással összefüggő államközi kapcsolatok teoretizálásához, gyakorlati elemzéséhez, valamint a döntéshozók számára szóló konkrét útmutatások létrehozásához. A teljesség igénye nélkül ezek közül a következöket említeném meg:

- Mivel Közép-Ázsia példája csak egyetlen esettanulmányt jelent, ami bizonyítja az értekezés hipotéziseit, mindenképpen érdemes ezt a keretet több esettanulmány segítségével tesztelni, melyek közül elsőként a TörökországSzíria diád elemzése lenne a leginkább kézenfekvő. Emellett érdemes lenne a határon átnyúló vízfelületek biztonságiatlanításának kérdését az Egyesült Államok-Kanada viszonyrendszerben is megvizsgálni, illetve további olyan eseteket feltárni, ahol ez a folyamat megvalósult, vagy elörehaladottabb állapotban van. A Duna esetében Magyarország is részét képezi egy vízmegosztási viszonyrendszernek, melyet szintén érdemes lenne a felvázolt 
keretek között elemezni. Mindezek révén a gyakorlatban is meg lehetne kísérelni a negyedik alhipotézis bizonyítását.

- A negyedik alhipotézis bizonyításához emellett a gyakorlati irányultságú policy brief-ek összeállítása is szorosan kapcsolódik, melyek alátámaszthatnák azon érvelést, hogy a konstruktivista elméleti keret és a koppenhágai iskola középszintü elmélete valóban elősegítheti a megoldási lehetőségek feltérképezését és megvalósítását a vízmegosztással összefüggő államközi kapcsolatok esetében.

- A közép-ázsiai hidropolitikai biztonsági komplexum kapcsán is érdemes lenne további vizsgálódásokat folytatni. Fontos lenne például Oroszország szerepének elemzése a közép-ázsiai régió vízmegosztással összefüggő államközi kapcsolatainak, illetve az államok vízügyi politikájának alakulásában, mely jelen értekezésben nem jelent meg, a kutatás során azonban kiderült, hogy egyértelmủen nagy jelentőséggel bír. A kutatás további szakaszaiban érdemes lenne több figyelmet szentelni a víz- és energiaügyek összekapcsolódásának is.

- A hidropolitikai biztonsági komplexumok elméletének bővítése, részletezése, több esettanulmányon való alkalmazása is fontos irányát képezheti a további kutatásoknak.

- Az etnográfiai módszer esetében további részletek feltárása lenne célszerü, különösen levéltári kutatások és helyszíni terepgyakorlatok révén, melyek elsődleges forrásokat biztosítanának a további vizsgálódásokhoz.

- A biztonságiasítás elméletének alkalmazása esetében jelen értekezés terjedelmébe már nem volt beilleszthető a 2.4.3. fejezetben leírt háromlépcsős biztonságiasítási folyamat megvalósulása az esettanulmányban. A későbbiekben mindenképpen érdemes lenne ezt a területet is megvizsgálni (annál is inkább, mivel ez szorosan kapcsolódik ahhoz az elméleti vitához, melynek központi kérdése, hogy a biztonságiasítás elmélete vajon értelmezhető-e autoriter kontextusokban, és amelyre jelen értekezés csak egy lábjegyzet erejéig tér ki).

- A diskurzuselemzés esetében a helyi nyelveken írt források vizsgálata jelentősen kibővíthetné a kutatás horizontját.

\subsection{Konklúzió}

Az értekezés megírása során végig Iver B. Neumann ([2008], p. 62) megfogalmazását tartottam irányadónak, miszerint a diskurzus „a rendszeresség egy 
szintjét tartja fenn a társadalmi kapcsolatokban, megteremti a cselekvés előfeltételeit. Korlátokat szab annak, hogyan rendeződnek el a világ dolgai, és így annak is, hogy az emberek milyen kategóriákban gondolkodnak a világról. Korlátokat szab annak, hogy mi lehetséges, és mi a „természetes” egy adott helyzetben. A diskurzus azonban nem determinálja a cselekedeteket. Mindig több mint egy lehetséges végkimenetel van.” Az elméleti áttekintés és a közép-ázsiai esettanulmány igazolta Neumann állítását. Látható, hogy a vízmegosztás kérdésében, különösen növekvőként érzékelt vízszükösség esetében, nagy lehet a valószínüsége és a realitása annak, hogy konfliktusos jelentéstartalmak jelennek meg, melyek könnyen eszkalálódhatnak, különösen, ha más feszültségforrások is jelen vannak az adott térségben. Ezt a jelenséget, amint az elemzés bemutatta, a neorealizmus is kiválóan képes leírni és értelmezni. A konstruktivista megközelítés azonban túllép ezen, és figyelembe veszi Neumann állítását, és elfogadja, hogy a materiális körülmények mellett a politikai-gazdasági-társadalmi kontextust közvetítő, vagy önmagában független változóként megjelenő diskurzusok jelentősen alakítják a biztonságpercepciókat, így a vízmegosztással összefüggő államközi kapcsolatokat. A végkimenetel tehát nem determinált, az érintett társadalmak egyértelműen cselekvő részesei, alkotói a folyamatoknak, így a vízmegosztás körül kialakuló konfliktus vagy együttmüködés általuk alakítható. Az értekezés tehát Frédéric Julien [2012] állítását is igazolta: „A hidropolitika az, amivé a társadalmak teszik.” Ha pedig mindez igaz, akkor a társadalmi folyamatokat mélységükben vizsgálni törekvő és vizsgálni képes elméleti keretek lesznek azok, amelyek a leginkább alkalmasak a hidropolitika teoretizálására - a konstruktivizmus tehát mindenképpen közöttük van,

Mindezek értelmében jelen értekezés a biztonságiatlanítás irányát jelöli meg kívánatosnak a vízmegosztással összefüggő államközi kapcsolatok rendezésének eléréséhez, akár a közép-ázsiai hidropolitikai komplexum specifikus példáját tekintve, akár általánosságban véve. A vízmegosztás kérdésének a biztonsági szintről a politikai szintre való visszavonása számos pozitív következménnyel járna, és ezeknek csak egyike lenne a katonai fenyegetés veszélyének megszünése. Először is, ha a politikai intézmények a megfelelő procedúrák mentén, minél több szereplőt bevonva kezelnék a vízmegosztás kérdését, jóval árnyaltabb megközelítések kerülhetnének előtérbe. Itt felmerülhet ellenérvként, hogy a közép-ázsiai vezetők autoriter módon kormányozzák államaikat - így nem is a koppenhágai iskola klasszikusan demokratikus rendszereket számításba vevő érvelése értelmében érvényesülne ez a tendencia, hanem arra építve, hogy a közép-ázsiai államoknak számos területen szüksége van a nemzetközi szervezetek közremüködésére. A nemzetközi szervezetek pedig éppen ezeket a 
feltételeket követelik meg: a civil társadalom kialakítása, a lakosság bevonása a különböző projektekbe, illetve az átláthatóság és a politikai részvétel növelése. Az államok közötti bi- és multilaterális tárgyalások során szintén a nemzetközi szervezetek szolgálhatnak közvetítőként, eszközeik pedig jelentős hozzájárulást jelentenek, például helyzetjelentések és hatástanulmányok elkészítésében - ami a szakmai szintre való visszavonás felé is továbbmozdíthatja a vízmegosztás kérdésének rendezését. A politikai szinten mindezek mellett a rendkívüliség és a túlélés biztosításának vízügyeket övező narratívája is inkább a háttérbe szorulhatna, hiszen egy folyamatos, kiszámítható államközi és államon belüli párbeszéd kialakulása esetén nincs szükség rendkívüli intézkedésekre sem.

Mielőtt azonban azt a következtetést vonnánk le mindebböl, hogy egy támadhatatlan, univerzális megoldást sikerült találni a vízmegosztás problémáinak kezelésére, (ami egyébként is idegen lenne a konstruktivizmus természetétől), több kitételt is szükséges tenni, melyek nélkül az elmélet gyakorlati alkalmazása súlyos hibákhoz vezethet. Először is, a biztonságiasítás elméletében „nem az egyének döntik el, hogy egy kérdés biztonsági kérdéssé váljon-e. A biztonságiasítás interszubjektív és társadalmilag konstruált" (Buzan et al. [1998], p. 31), ami azzal jár, hogy néhány egyén törekvései igen ritkán képesek arra, hogy átírják, megváltoztassák az akár évszázadokon, évezredeken át kialakult diskurzusokat. Ahogyan például a közép-ázsiai öntözéses gazdálkodás példája is bizonyítja, önteltség lenne azt gondolni, hogy rövid távon, politikai akarattal, ráadásul a régióban idegen, külső szereplőként, akár a kontextus hiányos ismeretében ezek a történetileg messze visszanyúló, társadalmilag mélyen beágyazott narratívák egyszerüen átírhatóak.

Jó példa erre az ENSZ Képzési és Kutatási Intézetének (UNITAR) Introduction to Water Diplomacy c. kurzusán [2015] ismertetett konfliktus-megoldási séma. Ez a séma eljut egészen addig a felismerésig, hogy a vízmegosztási tárgyalások esetében a jogi alapú vagy a hatalmi alapú párbeszédet a közös érdekek alapján szükséges átalakítani. Az átalakítás nehézségeinek ismertetése során ki is emeli a kultúra és az identitás ismeretének fontosságát (UNITAR [2015], pp. 109-110). Az átalakítást magát viszont egyszerüen a „vízkonfliktus-átalakítás” (water conflict transformation) mechanizmusában képzeli el, melynek „,reflexív szakaszában” az államok úgy döntenek, túllépnek az értékalapú megközelítéseken, és a valós abszolút hasznokat kezdik keresni (UNITAR [2015], pp. 8-11). A megoldást a források egyenlő elosztása hozza, ami minden érintett számára pozitív eredményt jelent. Ennek hatására a „részes államok közötti zéróösszegü, rugalmatlan álláspontok” helyett ugyanezek az államok „,pozitív 
összegű, együttműködő megoldásokat üdvözölnek” (UNITAR [2015], p. 8). A középázsiai esettanulmány részletes ismertetése után ez a szcenárió meglehetősen irreálisnak tünik, hiszen, amint az öntözéses gazdálkodás példájából kiderült, az értékek átalakítása nem zajlik le egyik napról a másikra. A költség-haszon-elemzés nem veheti át rövid távon a létező narratívák helyét, ahogyan az a gyapottermesztés más növényekkel való helyettesítésének elvetélt javaslataiban is egyértelműen látható volt, az erőforrások egyenlő és minden fél számára megfelelő megosztása pedig a hidrológiai és politikaigazdasági-társadalmi viszonyok ismeretében szintén nem tekinthető realisztikusnak a térségben. Az ENSZ általános megközelítésének legnagyobb hibája, hogy bár elméletben kiemeli a kontextus fontosságát, a gyakorlatban nem számol az egyes társadalmak jellegzetességeivel, beágyazott diskurzusaival, és ezek megváltoztatásának valós kihívásaival.

A biztonságiatlanítás révén történő megoldás tehát nem tekinthető rövid távon és egyszerüen megvalósítható, lépésről-lépésre leírható folyamatnak. Valódi megoldás csak akkor jöhet létre, ha alapos kulturális és politikai-gazdasági-társadalmi ismeretek birtokában, a vízmegosztási diskurzusok korábbi változásainak körülményeit feltárva, körültekintően és tisztelettel fordulunk az adott társadalmak felé, elősegítve azt, hogy saját, régióspecifikus megoldásokat találhassanak vízmegosztási problémáikra, hosszú távon átalakítva a biztonságpercepciókat meghatározó diskurzusokat. A konstruktivizmus és az annak alkalmazását segítő középszintű elméletek figyelembe vétele nagy segítséget nyújthat a döntéshozók és a nemzetközi szervezetek számára abban, hogy ezeket a folyamatokat a specifikus körülményeknek megfelelően alakíthassák.

Végezetül, az értekezés középpontjában álló konstruktivista elméleti keret hidropolitikai alkalmazására visszacsatolva, egy Emanuel Adler-idézettel zárnám értekezésemet: ,a konstruktivizmus többre képes, mint más tudományos magyarázatok a nemzetközi kapcsolatok elméletében, mivel a tudás és a bizonyítás logikai-deduktív és induktív eszközei mellett az interpretív módszerek széles skáláját is alkalmazza a kollektív jelentéseknek, az aktorok identitásainak és a politikai érdekek lényegének feltárására, mint például a szocio-kognitív folyamatok narratíváit (...) és a sürü leírás révén rögzített 'történeteket' (...)” (Adler [1997], p. 335). Jelen értekezés bizonyította, hogy mindez igaz a vízmegosztással összefüggő államközi kapcsolatok esetében is, a konstruktivizmus elméleti kerete így rendkívül alkalmas arra, hogy feltárja és kezelje a vízmegosztási feszültségek gyökereit, és gyakorlati alkalmazása révén előremozdítsa a 
nemzetközi együttmüködést a vízügyek területén, beemelve az emberi tudatosság szerepét annak alakításába.

Kézirat lezárása: 2016. augusztus 31. 


\section{FÜGGELÉK}

\section{1. ábra \\ Az Aral-tó XX. századi vízgyüjtő területe}

(Forrás: Yıldiz, Dursun [2014]:,, With Whom the Aral Sea was Crossed? Will it Return?" URL: http://www.hidropolitikakademi.org/en/with-whom-the-aral-sea-was-crossed-will-itreturn.html, letöltés ideje: 2015. október 10.)

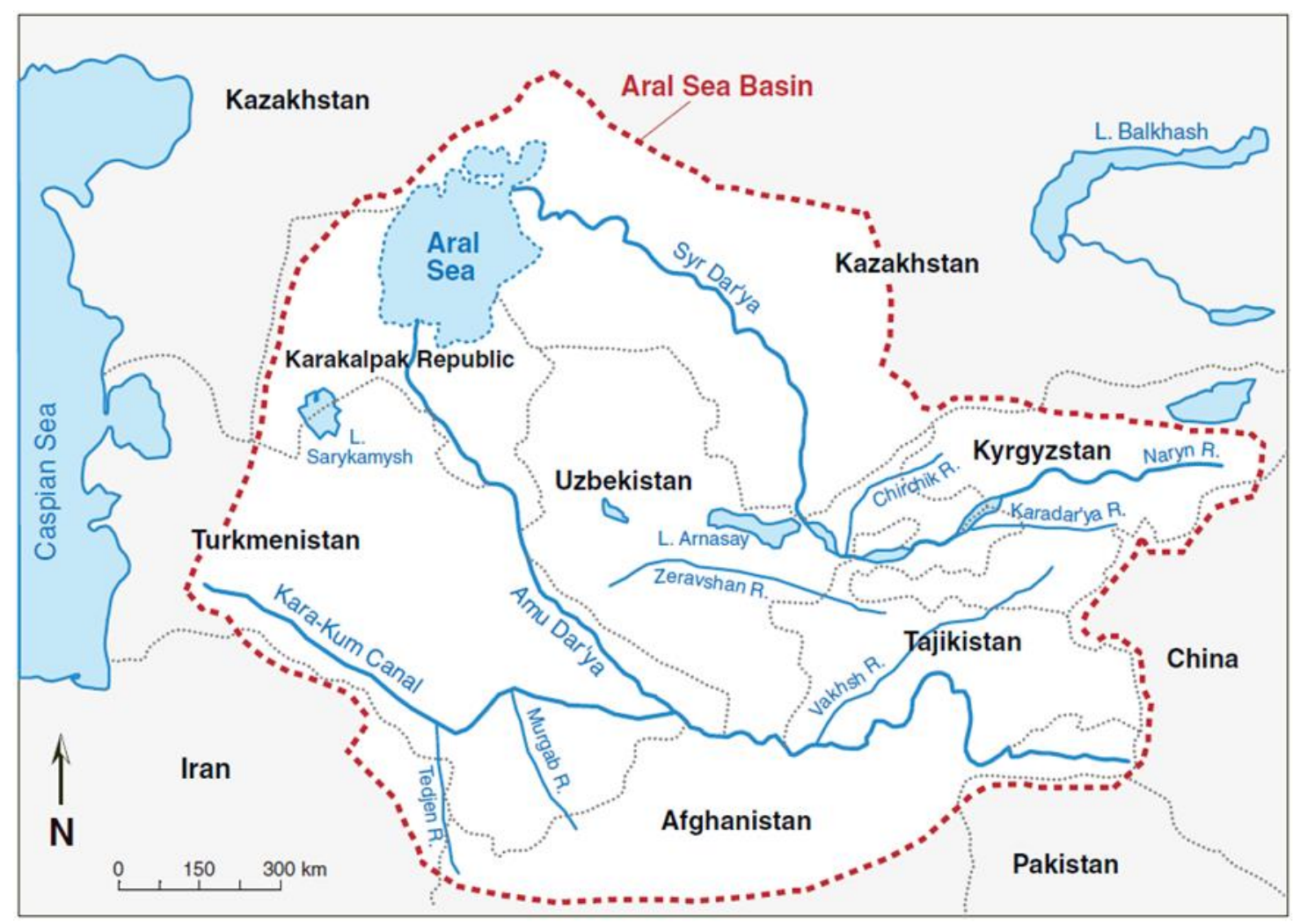




\section{2. ábra}

Hogyan válik egy kérdés biztonsági kihívássá?

(Forrás: Emmers, Ralf [2013]: "Securitization." In: Contemporary Security Studies, szerk. Collins, Alan, 131-144. Oxford University Press, Oxford, p. 133.)

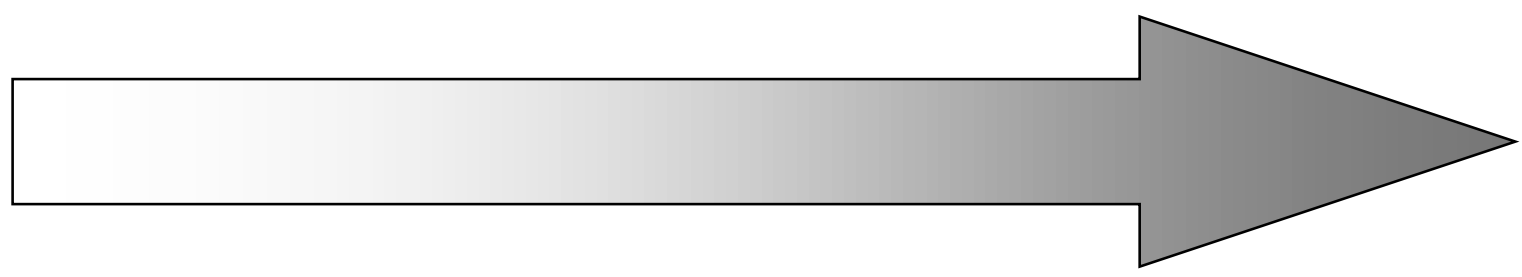

politikától mentes,

átpolitizált kérdés

biztonsági kérdés szakmai kérdés

az állam, a politikai

szféra nem érintett a

kérdésben,

a kérdésről nincs

nyilvános vita

$$
\begin{gathered}
\text { a kérdés kezelése a } \\
\text { politikai szféra alapvető } \\
\text { működéséhez szükséges } \\
\text { rendszereken keresztül } \\
\text { zajlik, }
\end{gathered}
$$

a kérdés a közpolitika részévé válik, kormányzati döntések születnek róla, állami erőforrásokat használnak fel a rendezéshez

$$
\text { végbemegy a }
$$

biztonságiasítás

háromlépcsős

folyamata, a kérdés biztonsági kihívássá válik, vagyis létében fenyegetni látszik egy vonatkozási tárgyat, a politikai szféra alapvető müködéséhez szükséges rendszerek már nem elegendőek a kérdés kezelésére 


\section{3. ábra}

A vízmegosztás szempontjából meghatározó biztonságpercepciók Közép-Ázsiában a három vizsgált időszakban

(a szerzö saját ábrája)

\begin{tabular}{|c|c|c|c|c|c|c|}
\hline \multirow{4}{*}{\multicolumn{2}{|c|}{ 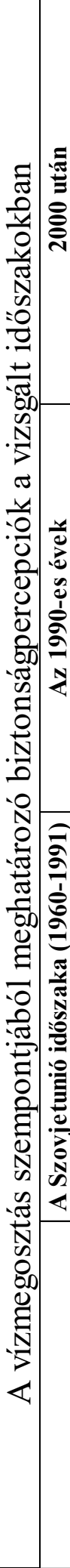 }} & 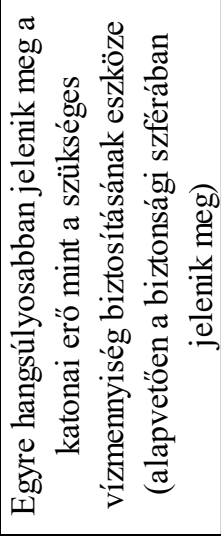 & 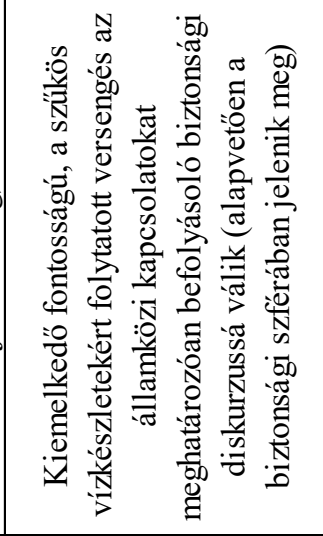 & 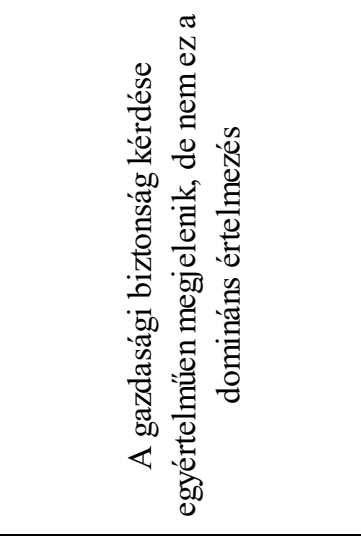 & 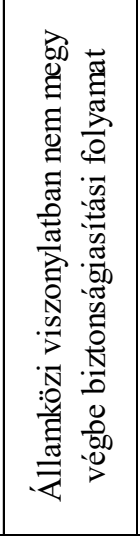 & 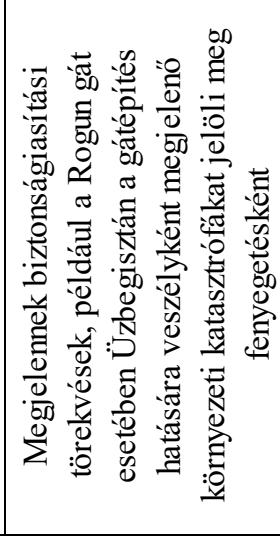 \\
\hline & & 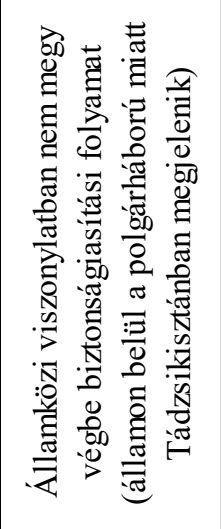 & 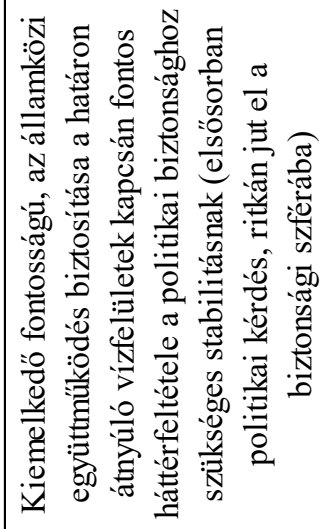 & 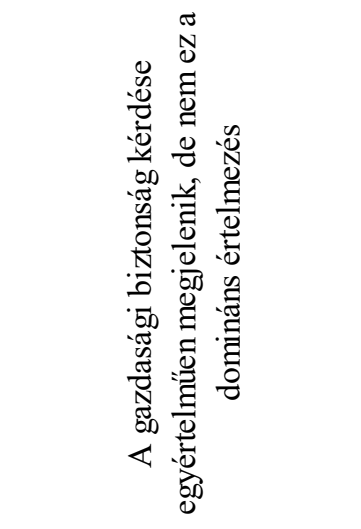 & 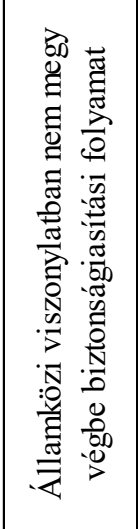 & 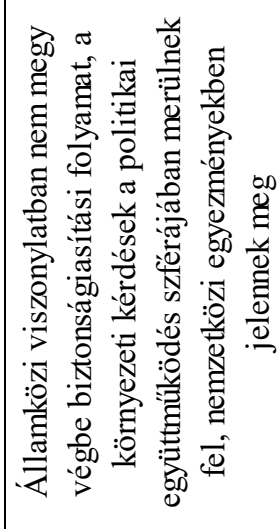 \\
\hline & & 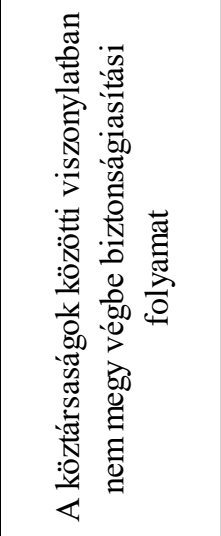 & 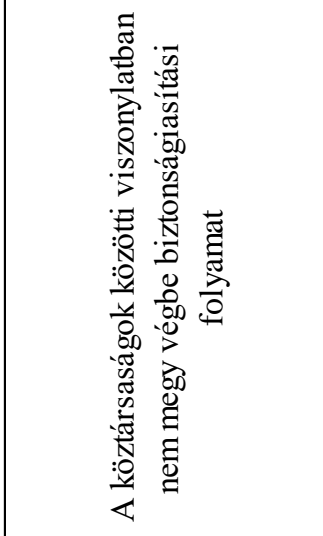 & 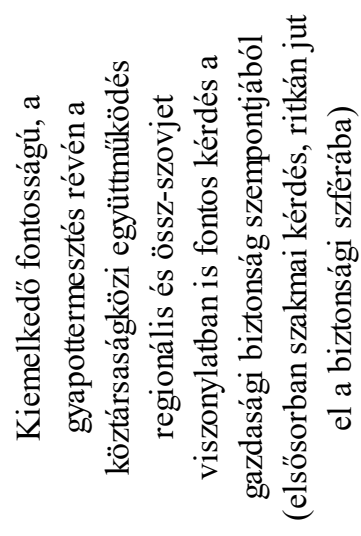 & 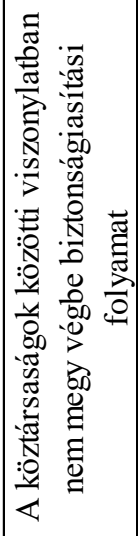 & 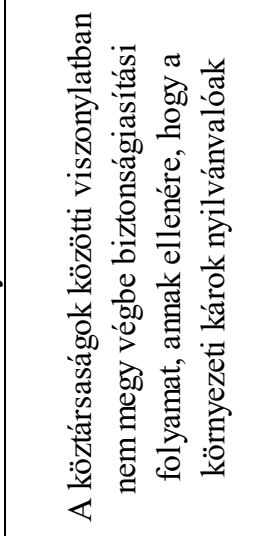 \\
\hline & & 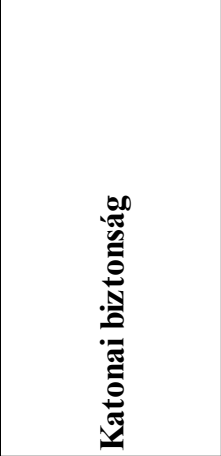 & 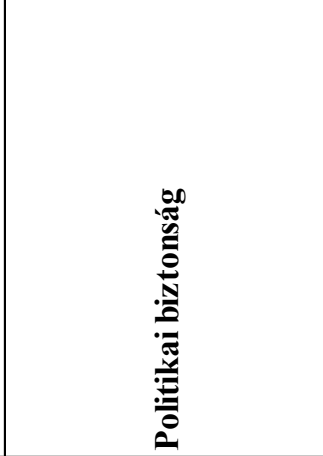 & 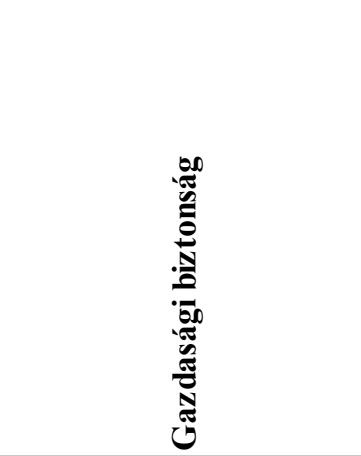 & 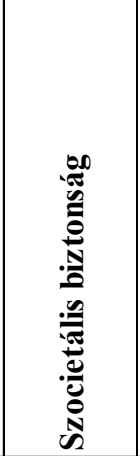 & 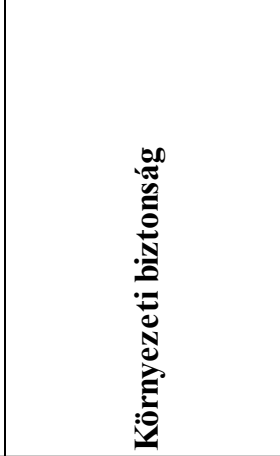 \\
\hline
\end{tabular}




\section{HIVATKOZÁSOK JEGYZÉKE}

\section{Elsődleges források}

566. jegyzökönyv: Az Amu-darja vizeinek átfogó felhasználásáról és védelméröl szóló program továbbfejlesztéséröl [Protocol 566: Improvement of the Scheme on Complex Use and Protection of Amu Darya Water Resources], a Szovjetunió Vízügyi Minisztériumának Tudományos és Technikai Tanácsa, 1987. szeptember 10 .

A Csu-Talasz Bizottság statútuma. [Statute of the Commission of the Republic of Kazakhstan and the Kyrgyz Republic on the Use of Water Management Facilities of Intergovernmental Status on the Rivers Chu and Talas], 2006. URL: http://www.chutalas-commission.org/eng/comm_whereabouts.php, letöltés ideje: 2016. augusztus 22.

A nukuszi nyilatkozat szövege. In: Mitchell, Ronald B. [2012]: 2002-2012: International Environmental Agreements Database Project (Version 2012.1). URL: http://iea.uoregon.edu/, letöltés ideje: 2012. december 6 .

A vízügyi szabályozás alapelvei a Szovjetunióban és tagköztársaságaiban. [Osnovy vodnogo zakonodatel'stva Sojuza SSR i sojuznyh respublik]. 1970. december 10. Vedomosti SSSR, 50. [1970], 566.

Akcióterv az Aral-tó vízgyüjtö területének környezeti, gazdasági és társadalmi helyzetének javítására a 2003-2010 közötti idöszakban. [Programme of Concrete Actions on Improvement of Environmental and Socio-Economic Situation in the Aral Sea Basin for the Period 2003-2010 (ASBP-2), Dushanbe]. 2002. október 6.

Alma-atai egyezmény, Megállapodás a Kazah Köztársaság, a Kirgiz Köztársaság, az Üzbég Köztársaság, a Tádzsik Köztársaság és Türkmenisztán között a vizügyi erőforrások közös igazgatásával és az államközi természeti erőforrások megörzésével kapcsolatos együttmüködésröl. [Agreement between the Republic of Kazakhstan, the Republic of Kyrgyzstan, the Republic of Uzbekistan, the Republic of Tajikistan and Turkmenistan on Cooperation in the Field of Joint Water Resources Management and Conservation of Interstate Sources]. 1992. február 18. 
Aral-tó megállapodás. Megállapodás az Aral-tó és környéke válságának közös kezelésére, a környezet állapotának javitására és a társadalmi-gazdasági fejlödés biztositására az Aral-tó térségében. [Agreement on Joint Activities for Addressing the Crisis of the Aral Sea and the Zone around the Sea, Improving the Environment and Ensuring the Social and Economic Development of the Aral Sea Region]. 1993. március 26.

Csu-Talasz megállapodás. Megállapodás a Kazah Köztársaság és a Kirgiz Köztársaság kormányai között a kormányközi státuszú vízügyi létesítmények használatáról a Csu és Talasz folyókon. [Agreement between the Government of the Republic of Kazakhstan and the Government of Kyrgyz Republic on the Use of Water Management Facilities of Intergovernmental Status on the Rivers Chu and Talas] 2000. február 21.

Egyezmény az országhatárokat átlépő vízfolyások és nemzetközi tavak védelméröl.

[Convention on the Protection and Use of Transboundary Watercourses and International Lakes]. 1997. március 12.

Megállapodás a Kazah Köztársaság, a Kirgiz Köztársaság és az Üzbég Köztársaság kormányai között a Szir-darja-medence víz- és energiaforrásainak felhasználásáról. [Agreement Between the Governments of the Republic of Kazakhstan, the Kyrgyz Republic, and the Republic of Uzbekistan on the Use of Water and Energy Resources of the Syr Darya Basin]. 1998. március 17.

Megállapodás a Tádzsik Köztársaság kormánya és az Üzbég Köztársaság kormánya között a vizkészletek és az energia ésszerü felhasználásának kérdésében folytatott együttmüködésröl. [Agreement between the Government of the Republic of Tajikistan and the Government of the Republic of Uzbekistan on Cooperation in the Area of Rational Water and Energy Uses]. 1998. február 4.; 1999. április 13.; 2000. január 14.

Megállapodás az IFAS és szervezetei státuszáról. [The Agreement about the Status of IFAS and its Organizations], 1999. április 9. 


\section{Másodlagos források}

Könyvek, monográfiák

Alexander, Jeffrey C [1995]: Fin de Siècle Social Theory: Relativism, Reduction, and the Problem of Reason. Verso, London.

Allan, Tony [2001]: The Middle East Water Question: Hydropolitics and the Global Economy. I. B. Tauris, London.

Bennett, Andrew - Checkel, Jeffrey T. [2014]: Process Tracing: From Metaphor to Analytic Tool. Cambridge University Press, Cambridge.

Buzan, Barry - Hansen, Lene [2009]: The Evolution of International Security Studies. Cambridge University Press, New York.

Buzan, Barry - Wæver, Ole - de Wilde, Jaap [1998]: Security: A New Framework for Analysis. Lynne Rienner Publishers, London.

Buzan, Barry - Wæver, Ole [2003]: Regions and Powers: The Structure of International Security. Cambridge University Press, Cambridge.

Buzan, Barry [1983]: People, States and Fear: The National Security Problem in International Relations. Harvester Wheatsheaf, Hertfordshire.

Delli Priscoli, Jerome - Wolf, Aaron T. [2009]: Managing and Transforming Water Conflicts. Cambridge University Press, Cambridge.

Dobrovits Mihály [2015]: Jurták és az EBESZ között: Iszlám és nemzetépités a volt Szovjetunió szunnita iszlám többségü régióiban. Balassi Kiadó, Budapest.

Elhance, Arun P. [1999]: Hydropolitics in the Third World: Conflict and Cooperation in International River Basins. United States Institute of Peace, Washington D. C.

Gazdag Ferenc [2011]: Biztonságpolitika: Biztonsági tanulmányok. Zrínyi Miklós Nemzetvédelmi Egyetem, Budapest.

Gee, James Paul [2011]: An Introduction to Discourse Analysis: Theory and Method. Routledge, New York.

Geertz, Clifford [1973]: The Interpretation of Cultures. Basic Books, New York.

George, Alexander L. - Bennett, Andrew [2005]: Case Studies and Theory

Development in the Social Sciences. MIT Press, Cambridge, MA. 
Homer-Dixon, Thomas F. [1999]: Environment, Scarcity and Violence. Princeton University Press, Princeton.

Jackson, Robert - Sorensen, Georg [2006]: Introduction to International Relations Theories and Approaches. Oxford University Press, Oxford.

Kiss J., László [2009]: Változó utak a külpolitika elméletében és elemzésében. Osiris, Budapest.

Lamont, Christoph [2015]: Research Methods in International Relations. SAGE Publications, London.

LeMarquand, David G. [1977]: International Rivers: The Politics of Cooperation. University of British Columbia, Vancouver.

Malthus, Thomas [1798/1998]: An Essay on the Principle of Population. Electronic Scholarly Publishing Project. URL:

http://www.esp.org/books/malthus/population/malthus.pdf, letöltés ideje: 2016. augusztus 22 .

Marton, Péter - Balogh, István - Rada, Péter [2015]: Biztonsági tanulmányok: Új fogalmi keretek és tanulságok a visegrádi országok számára. Antall József Tudásközpont, Budapest, 2016.

Micklin, Philip [1989]: The Water Management Crisis in Soviet Central Asia. Western Michigan University, Kalamazoo.

Middendorf, Alexander Theodor von [1882]: Очерки Ферганской долиньл. Orosz Birodalmi Tudományos Akadémia, Szentpétervár.

Mitchell, Timothy [2002]: Rule of Experts: Egypt, Techno-Politics, Modernity. University of California Press, Berkeley.

Myers, Norman [1993]: Ultimate Security: The Environmental Basis of Political Stability. Norton, New York.

O'Hara, Sarah [2003]: Drop by Drop: Water Management in the Southern Caucasus and Central Asia. LGI Fellowship Series, OSI/LGI, Budapest.

Roudik, Peter L. [2007]: The History of the Central Asian Republics. Greenwood Press, London.

Soffer, Arnon [1999]: Rivers of Fire: The Conflict over Water in the Middle East. Rowman \& Littlefield, Lanham. 
Soucek, Svat [2000]: A History of Inner Asia. Cambridge University Press, Cambridge.

Szabó, Márton [2003]: A diszkurzív politikatudomány alapjai: Elméletek és elemzések. L’Harmattan Kiadó, Budapest.

Wendt, Alexander [1999]: Social Theory of International Politics. Cambridge University Press, Cambridge.

Wittfogel, Karl [1957]: Oriental Despotism: A Comparative Study of Total Power. Yale University Press, Massachusetts.

Wolf, Aaron T. [1995]: Hydropolitics along the Jordan River: Scarce Water and its Impact on the Arab-Israeli Conflict. UN University Press, Tokyo.

Könyvfejezetek

Adler, Emanuel [2012]: „Constructivism in International Relations: Sources, Contributions and Debates." In: SAGE Handbook of International Relations. Szerk: Carlsnaes, Walter - Risse, Thomas - Simmons Beth A. SAGE Publications, London. 112-144.

Anderson-Levitt, Kathryn H. [2006]: „Ethnography.” In: Handbook of Complementary Methods in Education Research. Szerk.: Camilli, Greg - Elmore, Patricia Green, Judith. American Educational Research Association/Lawrence Erlbaum Associates, Washington D. C. 279-295.

Bayalieva, T. D. - Talitskii, V. Y. [1979]: „Materiali k istorii kul’turnovo stroitellstva v Toktogul'skom raione.” In: Kul'tura i byt Ketmen-Tiobinskikh Kirgizov: Po materialam etnog. expeditsii 1973. Szerk.: Bayalieva, T. D., Frunze.

Bure, Lea [2008]: „Chu-Talas Activities.” In: Transboundary Water Resources: A Foundation for Regional Stability in Central Asia. Szerk.: Moerlins, John E. Khankhasayev, Mikhail K. - Leitman, Steven F. - Makhmudov, Ernazar J. Springer, Dordrecht. 131-139

Checkel, Jeffrey T. [2008]: „Constructivism and Foreign Policy.” In: Foreign Policy: Theories, Actors, Cases. Szerk.: Smith, Steve - Hadfield, Amelia - Dunne, Tim. Oxford University Press, Oxford. 72-82. 
Checkel, Jeffrey T. [2008]: „Process Tracing.” In: Qualitative Methods in International Relations: A Pluralist Guide. Szerk.: Klotz, Audie - Prakash, Deepa. Palgrave Macmillan, Basingstoke. 114-130.

du Plessis, Anton [2000]: „Charting the Course of the Water Discourse through the Fog of International Relations Theory." In: Water Wars: Enduring Myth or Impending Reality. Szerk.: Solomon, Hussein - Turton, Anthony. ACCORD/Green Cross International and the African Water Issues Research Unit, Durham/Pretoria. 9-34.

Emmers, Ralf [2013]: „Securitization.” In: Contemporary Security Studies. Szerk.: Collins, Alan. Oxford University Press, Oxford. 131-144.

Glied Viktor [2009]: „Globális vízproblémák.” In: Vizkonfliktusok - küzdelem egy pohár vizért. Szerk.: Glied Viktor. Publikon, Pécs.

Gusterson, Hugh [2008]: „Ethnographic Research.” In: Qualitative Methods in International Relations: A Pluralist Guide. Szerk.: Klotz, Audie - Prakash, Deepa. Palgrave Macmillan, Basingstoke. 93-113.

Hill, Donald R. [2000]: „Physics and Mechanics. Civil and Hydraulic Engineering Industrial Processes and Manufacturing, and Craft Activities." In: The Age of Achievement. History of Civilizations of Central Asia Volume IV. The Age of Achievement: A. D. 750 to the End of the Fifteenth Century. Part Two: The Achievements. Szerk.: Bosworth, Clifford Edmund - Asimov, Muhammad Seyfeydinovich. UNESCO Publishing, Paris. 249-274.

Hurd, Ian [2008]: „Constructivism.” In: The Oxford Handbook of International Relations. Szerk.: Reus-Smit, Christian - Snidal, Duncan. Oxford University Press, Oxford. 298-316.

Islamov, Bakhtior A. [1994]: „Post-Soviet Central Asia and the CIS: The Economic Background of Independence.” In: Central Asia in Historical Perspective. Szerk.: Manz, Beatrice. Westview Press, Boulder. 202-232.

Kandiyoti, Deniz [2007]: „Introduction.” In: The Cotton Sector in Central Asia: Economic Policy and Development Challenges. Szerk.: Deniz Kandiyoti. University of London, London. 1-11.

Kipping, Martin [2009]: „Can 'Integrated Water Resources Management' Silence Malthusian Concerns? The Case of Central Asia.” In: Facing Global 
Environmental Change: Environmental, Human, Energy, Food, Health and

Water Security Concepts. Szerk.: Brauch, Hans Günter et al. Springer-Verlag, Berlin. 711-723.

Kurowska, Xymena - Friedrich Kratochwil [2012]: „The Social Constructivist Sensibility and Research on Common Security and Defence Policy." In: Explaining the EU's Common Security and Defence Policy: Theory in Action. Szerk.: Kurowska, Xymena - Breuer, Fabian. Palgrave Macmillan, Basingstoke. 86-110.

Libert, Bo - Lipponen, Annukka [2016]: „Challenges and Opportunities for Transboundary Water Cooperation in Central Asia: Findings from UNECE's Regional Assessment and Project Work." In: Water and Security in Central Asia: Solving a Rubik's Cube. Szerk.: Stucki, Virpi - Wegerich, Kai - Rahaman, Muhammed Mizanur - Varis, Olli. Routledge, New York. 171-182.

Lowi, Miriam - Rothman, Jay [1993]: „Arabs and Israelis: The Jordan River.” In:

Culture and Negotiations: The Resolution of Water Disputes. Szerk.: Faure, Guy Olivier - Rubin, Jeffrey Z. SAGE Publications, Newbury Park, 156-175.

McKinney, Daene C. [2004] „Cooperative Management of Transboundary Water Resources in Central Asia.” In: In the Tracks of Tamerlane: Central Asia's Path to the 21 st Century. Szerk.: Burghart, Daniel L. - Sabonis-Helf, Theresa. National Defense University, Center for Technology and National Security Policy, Washington D. C. 187-220.

Mirumachi, Naho [2013]: „Transboundary Water Security: Reviewing the Importance of National Regulatory and Accountability Capacities in International Transboundary River Basins." In: Water Security: Principles, Perspectives and Practices. Szerk.: Lankford, Bruce - Bakker, Karen - Zeitoun, Mark - Conway, Declan. Routledge, New York. 166-180.

Mutimer, David [2013]: „Critical Security Studies: A Schismatic History.” In:

Contemporary Security Studies. Szerk.: Collins, Alan. Oxford University Press, Oxford. 67-86.

Naff, Thomas [1994]: „Conflict and Water Use in the Middle East.” In: Water in the Arab World: Perspectives and Prognoses. Szerk.: Rogers, P. - Lyndon, P. Harvard University Division of Applied Sciences, Cambridge. 253-284. 
Neumann, Iver B. [2008]: „Discourse Analysis.” In: Qualitative Methods in International Relations: A Pluralist Guide. Szerk.: Klotz, Audie - Prakash, Deepa. Palgrave Macmillan, Basingstoke. 61-77.

Niyazov, Ilkhomjon - Ahrorov, Farhod - Cerny, Astrid - Edelstein, Michael R. [2012]: „Chapter 2: Going with the Flow: Economic Impacts from the Overuse of Irrigation." In: Disaster by Design: The Aral Sea and Its Lessons for Sustainability. Szerk.: Edelstein, Michael R. - Cerny, Astrid - Gadaev, Abror. Emerald Group Publishing Limited, Bingley. 17-27.

Oswald Spring, Ursula - Brauch, Hans Günter [2009]: „Securitizing Water.” In: Facing Global Environmental Change: Environmental, Human, Energy, Food, Health and Water Security Concepts. Szerk.: Brauch, Hans Günter et al. Springer, Berlin. 175-202.

Reus-Smit, Christian [2005]: „Constructivism.” In: Theories of International Relations. Szerk.: Burchill Scott et al. Palgrave, Basingstoke. 188-212.

Salter, Mark B. [2013]: „Introduction.” In: Research Methods in Critical Security Studies: An Introduction. Szerk.: Salter, Mark B. - Mutlu, Can E. Routledge, London. 51-58.

Schulz, Michael [1995]: „Turkey, Syria and Iraq: A Hydropolitical Security Complex.” In: Hydropolitics: Conflicts over Water as a Development Constraint. Szerk.: Ohlsson, Leif. Zed Books, London. 91-122.

Smith, Steve [1996]: „Positivism and Beyond.” In: International Theory: Positivism and Beyond. Szerk.: Smith, Steve - Booth, Ken - Zalewski, Marysia. Cambridge University Press, Cambridge. 11-46.

Smith, Steve [1997]: „New Approaches to International Theory.” In: The Globalization of World Politics: An Introduction to International Relations. Szerk.: Baylis, John - Smith, Steve. Oxford University Press, New York. 165-189.

Sodiqov, Alexander [2013]: „From Resettlement to Conflict: Development-Induced Involuntary Displacement and Violence in Tajikistan.” In: The Transformation of Tajikistan: The Sources of Statehood, Szerk.: Heathershaw, John - Herzig, Edmund. Routledge, New York. 49-65. 
Szálkai Kinga [2012]: „A szovjet etnográfia szerepe a közép-ázsiai nemzeti identitások megteremtésében.” In: Az érett kor itélete. Szerk.: Dobrovits Mihály. IX. Nemzetközi Vámbéry Konferencia, Dunaszerdahely, 334-356.

Szálkai Kinga [2015]: „A vízmegosztás biztonságiasításának változásai KözépÁzsiában (1960-2010). In: A biztonság szektorális értelmezése. Új kihívások a kutatás napirendjén. Szerk. Stepper Péter - Szálkai Kinga. Publikon, Pécs. 163189.

Szálkai Kinga [2015]: „Előszó: Szektorelmélet és biztonságiasítás.” In: A biztonság szektorális értelmezése. Új kihívások a kutatás napirendjén. Szerk.: Szálkai Kinga - Stepper Péter. Publikon Kiadó, Pécs. 7-20.

Szálkai Kinga [előkészületben]: „Vízügyi feszültségek Közép-Ázsiában: A Rogun vízerőmü-rendszer kérdése.” In: Megcsalt reményünk. Szerk.: Keller László. XII. Nemzetközi Vámbéry Konferencia, Lilium Aurum, Dunajska Stredá/Dunaszerdahely.

Vaissiére, Étienne de la [2005]: „,The Northern Side of the Zarafshan according to Ibn Hawqal. Central Asia from the Achaemenids to the Timurids." In: Archaeology, History, Ethnology, Culture. Materials of an International Scientific Conference. St. Petersburg, November 2-5, 2004. 323-325.

Wegerich, Kai [2008]: „Passing Over the Conflict: The Chu Talas Basin Agreement as a Model for Central Asia?" In: Central Asian Waters. Szerk.: Rahaman, M. M. Varis, O. Water and Development Publications, Helsinki University of Technology, 117-131.

Woolgar, Steve [1983]: „Irony in the Social Study of Science.” In: Science Observed. Szerk.: Knorr-Cetina, Karin D. - Mulkay, Michael. Sage, Beverly Hills. 239266.

Wunderer, Julia [2009]: „The Central Asian Water Regime as an Instrument for Crisis Prevention.” In: Facing Global Environmental Change: Environmental, Human, Energy, Food, Health and Water Security Concepts. Szerk.: Brauch, Hans Günter et al. Springer-Verlag, Berlin. 739-748.

Zehfuss, Maja [2006]: „Constructivism and Identity: A Dangerous Liaison.” In: Constructivism and International Relations. Szerk.: Guzzini, Stefano - Leander, Anna. Routledge, London. 93-117. 
Folyóiratcikkek, tanulmányok

Abdullaev, Iskandar-Rakhmatullaev, Shavkat [2015]: „,Transformation of Water Management in Central Asia: From State-Centric, Hydraulic Mission to SocioPolitical Control." Environmental Earth Science, Vol. 73. No. 2. 849-861. DOI: http://dx.doi.org/10.1007/s12665-013-2879-9.

Adler, Emanuel [1997]: "Seizing the Middle Ground: Constructivism in World Politics." European Journal of International Relations, Vol. 3. No. 3. 319-363. DOI: http://dx.doi.org/10.1177/1354066197003003003.

Ahmad, Masood - Wasiq, Mahwash [2004]: „Water Resource Development in Northern Afghanistan and Its Implications for Amu Darya Basin.” World Bank Working Paper, No. 36. DOI: http://dx.doi.org/10.1596/0-8213-5890-1.

Allan, Tony [2002]: „Water Security in the Middle East: The Hydro-Politics of Global Solutions.” Working Paper, SOAS/King's College London, Water Research Group. URL:

http://mercury.ethz.ch/serviceengine/Files/ISN/6839/ipublicationdocument_singl edocument/44a0a220-a9cd-49eb-9778-f55c0e85cbeb/en/doc_6841_290_en.pdf, letöltés ideje: 2015. augusztus 18 .

Allan, Tony [2003a]: „Virtual Water - the Water, Food, and Trade Nexus: Useful Concept or Misleading Metaphor?” IWRA, Water International, Vol. 28. No. 1. 4-11. DOI: http://dx.doi.org/10.1080/02508060.2003.9724812.

Allan, Tony [2003b]: IWRM/IWRAM: a New Sanctioned Discourse? Occasional Paper 50, SOAS Water Issues Study Group School of Oriental and African Studies/King's College London University of London. URL:

http://www.soas.ac.uk/water/publications/papers/file38393.pdf, letöltés ideje: 2015. augusztus 19 .

Allouche, Jeremy [2004]: „A Source of Regional Tension in Central Asia: The Case of Water." CP 6: The Illusions of Transition: which perspectives for Central Asia and the Caucasus? Graduate Institute of International Studies, Geneva, 92-104.

Allouche, Jeremy [2007]: „The Governance of Central Asian Waters: National Interests Versus Regional Cooperation.” Disarmament Forum, No. 4. 45-55. 
Baghel, Ravi - Nüsser, Marcus [2010]: „Discussing Large Dams in Asia after the World Commission on Dams: Is a Political Ecology Approach the Way forward?” Water Alternatives, Vol. 3. No. 2. 231-248.

Bennett, Andrew - Checkel, Jeffrey T. [2012]: „Process Tracing: From Philosophical Roots to Best Practices." Simons Papers in Security and Development, No. 21/2012. School for International Studies, Simon Fraser University, Vancouver, June 2012. 5-48.

Bernauer, Thomas - Siegfried, Tobias [2012]: „Climate Change and International Water Conflict in Central Asia." Journal of Peace Research, Vol. 49. No. 1. 227-239. DOI: http://dx.doi.org/10.1177/0022343311425843.

Blakkisrud, Helge -Nozimova, Shahnoza [2010]: „History Writing and Nation Building in Post-Independence Tajikistan." Nationalities Papers: The Journal of Nationalism and Ethnicity, Vol. 38. No. 2. 173-189. DOI: http://dx.doi.org/10.1080/00905990903517835.

Bobojonov, Ihtiyor et al. [2013]: „Options and Constraints for Crop Diversification: A Case Study in Sustainable Agriculture in Uzbekistan." Agroecology and Sustainable Food Systems, Vol. 37. No. 7. 788-811. DOI: http://dx.doi.org/10.1080/21683565.2013.775539.

Bromber, Katrin - Féaux de la Croix, Jeanne - Lange, Katharina [2014]: „,The Temporal Politics of Big Dams in Africa, the Middle East, and Asia: By Way of an Introduction." Water History. Vol. 6. No. 4. 289-296. DOI: http://dx.doi.org/10.1007/s12685-014-0111-9.

Brown, Amber - Matlock, Marty D. [2011]: „A Review of Water Scarcity Indices and Methodologies.” Sustainability Consortium White Paper No. 106.

Carius, Alexander - Dabelko, Geoffrey D. - Wolf, Aaron T. [2004]: „Water, Conflict and Cooperation." Wilson Centre, Environment Change and Security Program Report, Issue 10. URL:

http://www.wilsoncenter.org/sites/default/files/ecspr10_unf-caribelko.pdf, letöltés ideje: 2015. augusztus 13.

Carver, Terrell [2002]: „Discourse Analysis and the 'Linguistic Turn.”' European Political Sciences, Autumn 2002. 50-53. DOI:

http://dx.doi.org/10.1057/eps.2002.46. 
Collier, David [2011]: „Understanding Process Tracing.” Political Science and Politics, Vol. 44. No. 4. 823-830. DOI: http://dx.doi.org/10.1017/S1049096511001429.

Dinar, Shlomi [2012]: „The Geographic Dimensions of Hydro-politics: International Freshwater in the Middle East, North Africa, and Central Asia.” Eurasian Geography and Economics, Vol. 53. No. 1. 115-142. DOI: http://dx.doi.org/10.2747/1539-7216.53.1.115.

Dobrovits Mihály [2011]: „Közép-Ázsia a XXI. század elején.” MKI-Tanulmányok, $2011 / 5$.

Féaux de la Croix, Jeanne - Suyarkulova, Mohira [2015]: „,The Rogun Complex: Public Roles and Historic Experiences of Dam-Building in Tajikistan and Kyrgyzstan.” Cahiers d'Asie Centrale, 25. 103-132.

Féaux de la Croix, Jeanne [2010]: „Building Dams in Central Asia: Sacred Products of the Soviet and Post-Soviet States?" Anthropology News, Vol. 51. No. 2. 6-7. DOI: http://dx.doi.org/10.1111/j.1556-3502.2010.51206.x.

Féaux de la Croix, Jeanne [2011]: „Moving Metaphors We Live by: Water and Flow in the Social Sciences and around Hydroelectric Dams in Kyrgyzstan.” Central Asian Survey, Vol. 30. No. 3-4. 487-502. DOI: http://dx.doi.org/10.1080/02634937.2011.614097.

Féaux de la Croix, Jeanne [2014]: „Erfahrungen mit den sowjetischen und postsowjetischen Staudammprojekten am Naryn Fluss." Hannoversche Geographische Arbeiten, Band 62. 90-100.

Foucault, Michel [1970/1991]: „A diskurzus rendje.” Holmi, 7. 868-889.

Furlong, Kathryn [2006]: "Hidden Theories, Troubled Waters: International Relations, the 'Territorial Trap', and the South African Development Community's Transboundary Waters.” Political Geography, Vol. 25. 438-458. DOI: http://dx.doi.org/10.1016/j.polgeo.2005.12.008.

Garcés de los Fayos, Fernando [2014]: „,The World Bank Considers Feasible the Building of the Tajik Rogun Dam.” European Parliament, Directorate-General for External Policies, Policy Department. URL: http://www.europarl.europa.eu/RegData/etudes/IDAN/2014/536392/EXPO_IDA (2014)536392_EN.pdf, letöltés ideje: 2014. december 10. 
Gleick, Peter H. [1993]: „Water and Conflict: Fresh Water Resources and International Security.” International Security, Vol. 18. No. 1. 79-112. DOI: http://dx.doi.org/10.2307/2539033.

Gleick, Peter H. [2010]: „Climate Change, Exponential Curves, Water Resources, and Unprecedented Threats to Humanity." Climatic Change, No. 100. 125-129. DOI: http://dx.doi.org/10.1007/s10584-010-9831-8.

Gleick, Peter H. [2011]: The World's Water: The Biennial Report on Freshwater Resources. Island Press, Washington DC. DOI: http://dx.doi.org/10.1007/978-159726-228-6.

Haftendorn, Helga [2000]: „Water and International Conflict.” Third World Quarterly, Vol. 21. No. 1. 51-68. DOI: http://dx.doi.org/10.1080/01436590013224.

Homer-Dixon, Thomas F. [1994]: „Environmental Scarcities and Violent Conflict: Evidence from Cases," International Security, Vol. 19. No. 1. 5-40. DOI: http://dx.doi.org/10.2307/2539147.

Hopf, Ted [1998]: „The Promise of Constructivism in International Relations Theory.” International Security, Vol. 23. No. 1. 171-200. DOI:

http://dx.doi.org/10.2307/2539267.

Jongerden, Joost [2010]: „Dams and Politics in Turkey: Utilizing Water, Developing Conflict.” Middle East Policy, Vol. 17. No. 1. 137-143. DOI: http://dx.doi.org/10.1111/j.1475-4967.2010.00432.x.

Josephson, Paul R. [1995]: „'Projects of the Century' in Soviet History: Large-Scale Technologies from Lenin to Gorbachev." Technology and Culture, Vol. 36. No. 3. 519-559. DOI: http://dx.doi.org/10.2307/3107240.

Julien, Frédéric [2012]: „Hydropolitics is What Societies Make of It (or Why We Need a Constructivist Approach to the Geopolitics of Water).” International Journal of Sustainable Society, Vol. 4. No.1-2. 45-71. DOI: http://dx.doi.org/10.1504/IJSSOC.2012.044665.

Juraev, Shairbek [2012]: „Central Asia’s Cold War? Water and Politics in Uzbek-Tajik Relations.” PONARS Eurasia Policy Memo 217, September 2012, 1-5.

Karaev, Zainiddin [2005]: „Water Diplomacy in Central Asia.” Middle East Review of International Affairs, Vol. 9. No. 1. 63-69. 
Karimov, Kh. S. - Abid, M. - Ahmed, N. - Akhmedov, Kh. M. - Petrov, G. N. [2013]: „Rogun Hydropower Plant Project of Tajikistan: Expected Benefits for Neighboring Countries.” World Applied Sciences Journal, Vol. 26. No. 2. 239-

243. DOI: http://dx.doi.org/10.5829/idosi.wasj.2013.26.02.1404.

Katona Magda [1997]: „Szovjetesítés és a tradicionális agrárviszonyok KözépÁzsiában.” Agrártörténeti Szemle XXXIX/3-4. 601-616.

Lapin, Konsztantyin [1956]: „A Volga leigázása.” Új Szó, IX. évfolyam, 32. szám. 4.

Makhmedov, Yusuf - Madmusoev, Mamurjon - Tavarov, Suhkrob [2012]: „Water and Energy Disputes between Tajikistan and Uzbekistan and Their Negative Influence on Regional Co-operation.” RUSHD NGO, Tajikistan.

March, Andrew F. [2002]: „The Use and Abuse of History: 'National Ideology’ as Transcendental Object in Islam Karimov's 'Ideology of National Independence.” Central Asian Survey, Vol. 21. No. 4. 371-384. DOI: http://dx.doi.org/10.1080/0263493032000053190.

Menga, Filippo [2014]: „Building a Nation through a Dam: the Case of Rogun in Tajikistan." Nationalities Papers: The Journal of Nationalism and Ethnicity, Vol. 43. No. 3. 1-16. DOI: http://dx.doi.org/10.1080/00905992.2014.924489.

Micklin, Philip [1983]: „Soviet Water Diversion Plans: Implications for Kazakhstan and Central Asia." Central Asian Survey, Vol. 1. No. 4. 9-43. DOI: http://dx.doi.org/10.1080/02634938308400408.

Micklin, Philip [1987]: „The Fate of "Sibaral”: Soviet Water Politics in the Gorbachev Era.” Central Asian Survey, Vol. 6. No. 2. 67-88. DOI: http://dx.doi.org/10.1080/02634938708400585.

Micklin, Philip [2007]: „The Aral Sea Disaster.” Annual Review of Earth and Planetary Sciences, No. 35. 47-72. DOI:

http://dx.doi.org/10.1146/annurev.earth.35.031306.140120.

Molle, François - Mollinga, Peter P. - Wester, Philippus [2009] „Hydraulic Bureaucracies and the Hydraulic Mission: Flows of Water, Flows of Power.” Water Alternatives, Vol. 2. No. 3. 328-349.

Mollinga, Peter P. [2001]: "Water and Politics: Levels, Rational Choice and South Indian Canal Irrigation.” Futures, Vol. 33. No. 8. 733-752. DOI: http://dx.doi.org/10.1016/S0016-3287(01)00016-7. 
Prüs-Üstün, Annette et al. [2014]: „Burden of Disease from Inadequate Water,

Sanitation and Hygiene in Low- and Middle-Income Settings: A Retrospective Analysis of Data from 145 Countries." Tropical Medicine and International

Health, Vol. 19. No. 8. 894-905. DOI: http://dx.doi.org/10.1111/tmi.12329.

Rakhmatullaev, Shavkat - Huneau, Frédéric - Celle-Jeanton, Helene - Le Coustumer, Philippe - Motelica-Heino, Mikael et al. [2013]: „Water Reservoirs, Irrigation and Sedimentation in Central Asia: A First-Cut Assessment for Uzbekistan." Environmental Earth Science, Vol. 68. No. 4. 985-998. DOI: http://dx.doi.org/10.1007/s12665-012-1802-0.

Schmeier, Susanne [2010]: „Governing International Watercourses: Perspectives from Different Disciplines." Hertie School of Governance Working Papers, No. 53. 133. DOI: http://dx.doi.org/10.2139/ssrn.1658899.

Selby, Jan [2003]: „Dressing up Domination as 'Cooperation': The Case of IsraeliPalestinian Water Relations.” Review of International Studies. Vol. 29. No. 1. 121-138. DOI: http://dx.doi.org/10.1017/S026021050300007X.

Spoor, Max [1993]: „Transition to Market Economies in Former Soviet Central Asia: Dependency, Cotton and Water" The European Journal of Development Research, Vol. 5. No. 2. 142-158. DOI: http://dx.doi.org/10.1080/09578819308426591.

Suyarkulova, Mohira [2014]: „Between National Idea and International Conflict: The Roghun HHP as an Anticolonial Endeavor, Body of the Nation, and National Wealth.” Water History, Vol. 6. No. 4. 367-383. DOI:

http://dx.doi.org/10.1007/s12685-014-0113-7.

Szálkai Kinga [2015]: „Kazah-kirgiz vízügyi megállapodások: A regionális együttmüködés záloga?” AJRC Elemzések, URL jelenleg nem elérhető.

Szálkai Kinga [2015]: „Nemzetközi vízügyek - konfliktus vagy együttmüködés? (1).” AJRC Elemzések, URL jelenleg nem elérhető.

Szálkai Kinga [2015]: „Nemzetközi vízügyek - konfliktus vagy együttmüködés? (2).” AJRC Elemzések, URL jelenleg nem elérhető.

Szálkai Kinga [2015]: „Vízkészleteink jövője: Mit tehet az ENSZ vízbiztonságunk érdekében? (1).” AJRC Elemzések, URL jelenleg nem elérhető. 
Trottier, Julie [2008]: „Water Wars: The Rise of a Hegemonic Concept: Exploring the Making of the Water War and Water Peace Belief within the Israeli-Palestinian Conflict." UNESCO-Green Cross International Project "From Potential Conflict to Cooperation Potential (PCCP): Water for Peace.” URL:

http://armspark.msem.univ-montp2.fr/bfpvolta/admin/biblio/Trottier.pdf. letöltés ideje: 2016. augusztus 22.

Virág, Attila [2014]: „Diskurzuselemzés a politika- és vezetéstudományban.” Vezetéstudomány, XLV. évf. 3. szám. 30-38.

Vrasti, Wanda [2008]: „The Strange Case of Ethnography and International Relations.” Millennium Journal of International Studies, Vol. 37. No. 2. 279-301. DOI: http://dx.doi.org/10.1177/0305829808097641.

Warner, Jeroen F. - Zeitoun, Mark [2008]: „International Relations Theory and Water Do Mix: A Response to Furlong's Troubled Waters, Hydrohegemony and International Water Relations.” Political Geography, Vol. 27. 802-810. DOI: http://dx.doi.org/10.1016/j.polgeo.2008.08.006.

Weinthal, Erika [2006]: „Water Conflict and Cooperation in Central Asia.” Human Development Report, No. 32. 2-36.

Wendt, Alexander [1995]: „Constructing International Politics”. International Security, No. 20. 71-81. DOI: http://dx.doi.org/10.2307/2539217.

Wolf, Aaron T. - Yoffe, Shira B. - Giordano, Mark [2003]: „International Waters: Identifying Basins at Risk.” Water Policy, No. 5. 29-60.

Wolf, Aaron T. [1998]: „Conflict and Cooperation along International Waterways.” Water Policy, No. 1. 251-265. DOI: http://dx.doi.org/10.1016/S13667017(98)00019-1.

Wooden, Amanda E. [2014]: „Kyrgyzstan's Dark Ages: Framing and the 2010 Hydroelectric Revolution.” Central Asian Survey, Vol. 33. No. 4. 463-481. DOI: http://dx.doi.org/10.1080/02634937.2014.989755.

Zeitoun, Mark - Mirumachi, Naho [2008]: „,Transboundary Water Interaction I: Reconsidering Conflict and Cooperation.” International Environmental Agreements: Politics, Law and Economics, No. 8. 297-316. DOI: http://dx.doi.org/10.1007/s10784-008-9083-5. 
Zeitoun, Mark - Warner, Jeroen F. [2000]: „Hydro-hegemony: A Framework for Analysis of Transboundary Water Conflicts.” Water Policy, No. 8. 435-460.

DOI: http://dx.doi.org/10.2166/wp.2006.054.

Nemzetközi szervezetek hivatalos oldalai, jelentései

2030 Water Resources Group (WRG) [2009]: Charting our water future. URL:

http://www.mckinsey.com/ /media/mckinsey/dotcom/client_service/sustainabilit $\mathrm{y} / \mathrm{pdfs} /$ charting\%200ur\%20water\%20future/charting_our_water_future_full_rep ort_ashx, letöltés ideje: 2015. május 20., 41.

Amu Darya River Basin Network [2015]: Amu Darya River Basin. URL:

http://amudaryabasin.net/content/amu-darya-river-basin, letöltés ideje: 2015. október 2.

Asian Development Bank [ADB] [2013]: Integrated Water Resources Management and the People of Asia. URL: http://www.forumadb.org/docs/ngoFORUM_IWRMP.pdf, letöltés ideje: 2015. október 10.

CAWATERinfo [2012]: „Water Resources of the Aral Sea Basin.” URL: http://www.cawater-info.net/aral/water_e.htm, letöltés ideje: 2012. május 5.

Central Intelligence Agency (CIA) [2014a]: The World Factbook - Kazakhstan. https://www.cia.gov/library/publications/the-world-factbook/geos/kz.html, letöltés ideje: 2015. február 17.

Central Intelligence Agency (CIA) [2014b]: The World Factbook - Kyrgyzstan. https://www.cia.gov/library/publications/the-world-factbook/geos/kg.html, letöltés ideje: 2015. február 17.

Central Intelligence Agency (CIA) [2014c]: The World Factbook - Tajikistan. https://www.cia.gov/library/publications/the-world-factbook/geos/ti.html, letöltés ideje: 2015. február 10.

Central Intelligence Agency (CIA) [2014d]: The World Factbook - Uzbekistan. https://www.cia.gov/library/publications/the-world-factbook/geos/uz.html, letöltés ideje: 2015. február 17.

Chu-Talas Commission [2011]: Report on Activities of the Commission of the Republic of Kazakhstan and the Kyrgyz Republic on the Use of Water Management Facilities of Intergovernmental Status on the Chu and Talas Rivers in 2010- 
2011. URL: http://chutalas-

commission.org/files/docs/ChuTalasComReport\%2010_11_ENG_FIN.pdf, letöltés ideje: 2015. július 20.

Energy Charter Secretariat (ECS) [2013]: „In-Depth Energy Efficiency Review, Tajikistan.” ECS Brussels. URL:

http://www.encharter.org/fileadmin/user_upload/Publications/Tajikistan_EE_20 13_ENG.pdf, letöltés ideje: 2014. december 10.

ENVSEC [2011]: Environment and Security in the Amu Darya Basin. URL: http://www.grida.no/publications/security/book.aspx, letöltés ideje: 2014. december 10 .

European Dialogue [2012]: „Rogun Damage to Uzbekistan Estimated at \$600 Million US Experts." URL: http://eurodialogue.org/Rogun-damage-to-Uzbekistanestimated-at-600-million\%E2\%80\%94US-experts, letöltve: 2014. december 10.

EU-UNDP [2011]: Overview of Regional Transboundary Water Agreements, Institutions and Relevant Legal/Policy Activities in Central Asia. Promoting Integrated Water Resources Management and Fostering Transboundary Dialogue in Central Asia EU-UNDP Project (2008-2012). URL: http://centralasia.iwlearn.org/publications/projectdocuments/regional/wateragreements-in-central-asia-2011, letöltés ideje: 2015. július 20.

Executive Committee of International Fund for Saving Aral Sea. URL: http://ecifas.org/en/, letöltés ideje: 2015. október 10.

FAO [1997]: Irrigation in the Countries of the Former Soviet Union in Figures. Food and Agriculture Organisation, Róma.

Food and Agriculture Organisation (FAO) [2014a]: Aquastat: Kazakhstan Country Profile. URL:

http://www.fao.org/nr/water/aquastat/countries_regions/KAZ/KAZ-CP_eng.pdf, letöltés ideje: 2015. október 10.

Food and Agriculture Organisation (FAO) [2014b]: Aquastat: Kyrgyzstan Country Profile. URL:

http://www.fao.org/hr/water/aquastat/countries_regions/KGZ/KGZ-CP_eng.pdf, letöltés ideje: 2015 . október 10. 
Food and Agriculture Organisation (FAO) [2014c]: Aquastat: Tajikistan Country Profile. URL: http://www.fao.org/nr/water/aquastat/countries_regions/TJK/TJKCP_eng.pdf, letöltés ideje: 2015. október 10 .

Food and Agriculture Organisation (FAO) [2014d]: Aquastat: Uzbekistan Country Profile. http://www.fao.org/nr/water/aquastat/countries_regions/UZB/UZBCP_eng.pdf, (letöltve: 2014. december 10.)

Global Water Partnership (GWP) [2010]: What is IWRM? URL:

http://www.gwp.org/The-Challenge/What-is-IWRM/, letöltés ideje: 2015. augusztus 18 .

Global Water Partnership of Central Asia and Caucasus (GWP CACENA) [2011]: Water Resources Management in Uzbekistan. GWP CACENA, Taskent. URL: http://www.cawaterinfo.net/library/eng/water_resources_management_in_uzbekistan.pdf, letöltés ideje: 2016. április 2.

Human Rights Watch (HRW) [2014]: „We Suffered When We Came Here”: Rights Violations Linked to Resettlements for Tajikistan's Rogun Dam.” URL: http://www.hrw.org/sites/default/files/reports/tajikistan0614_ForUpload_0_0.pdf , letöltés ideje: 2015. január 17.

International Crisis Group (ICG) [2002]: „Central Asia: Water and Conflict.” ICG Asia Report 34.

International Crisis Group [ICG] [2014]: „Water Pressures in Central Asia.” Europe and Central Asia Report $\mathrm{N}^{\circ} 233$.

International Hydropower Association (IHA) [2013]: Tajikistan Country Profile. URL: http://www.hydropower.org/country-profiles/tajikistan, letöltés ideje: 2014. december 10.

Interstate Commission for Water Coordination of Central Asia (ICWC) Basin Water Organization "Syrdarya". URL: http://www.icwc-aral.uz/bwosyr.htm, letöltés ideje: 2015. október 10.

Interstate Commission for Water Coordination of Central Asia (ICWC) Basin Water Organization “Amudarya”. URL: http://www.icwc-aral.uz/bwoamu.htm, letöltés ideje: 2015. október 10. 
Interstate Commission for Water Coordination of Central Asia (ICWC). URL:

http://www.icwc-aral.uz/. letöltés ideje: 2015. október 10.

IPCC [2008]: Technical Paper VI: Climate change and water. URL:

http://ipcc.ch/pdf/technical-papers/climate-change-water-en.pdf, letöltés ideje: 2015. május 20.

OECD [2007/8]: Alternative Ways of Providing Water: Emerging Options and Their Policy Implications. URL: http://www.oecd.org/env/resources/42349741.pdf, letöltés ideje: 2015. augusztus 18.

U.S. Environmental Protection Agency, Office of Water [2012]: National Water Program Strategy: Response to Climate Change. URL:

http://water.epa.gov/scitech/climatechange/upload/impacts_on_water_resources. pdf, letöltés ideje: 2015. május 20.

UNECE: Chu and Talas Rivers Project [2015]. URL:

http://www.unece.org/env/water/centralasia/chutalas.html, letöltés ideje: 2015. július 20 .

UNECE-OSCE [2011]: Project Report: Development of cooperation on the Chu and Talas Rivers (Chu-Talas II). URL:

http://www.unece.org/fileadmin/DAM/env/water/Chu-

Talas/ChuTalas_II_Project_Report_Short_ENG.pdf, letöltés ideje: 2015. július 20.

UNECE-OSCE-UNESCAP [2006]: Support for the Creation of a Transboundary Water Commission on the Chu and Talas Rivers between Kazakhstan and Kyrgyzstan (Chu-Talas I.) URL: http://www.unece.org/fileadmin/DAM/env/water/ChuTalas/OSCE_Chu_Talas_Final_Report.pdf, letöltés ideje: 2015. július 20.

UNEP [2008]: Vital Water Graphics: An Overview of the State of the World's Fresh and Marine Waters - 2nd Edition. URL: http://www.unep.org/dewa/vitalwater/, letöltés ideje: 2015. február 17.

UNESCO [2012]: Managing Water under Uncertainty and Risk: The United Nations World Water Development Report 4, Volume 1. http://unesdoc.unesco.org/images/0021/002156/215644e.pdf, letöltés ideje: 2015. február 17. 
United Nations (UN) [2013]: Water for Life Decade: Transboundary Waters. URL: http://www.un.org/waterforlifedecade/transboundary_waters.shtml, letöltés ideje: 2013. október 26.

United Nations University (UNU) [2011]: Former National Leaders: Water a Global Security Issue. URL: http://unu.edu/media-relations/releases/water-called-aglobal-security-issue.html, letöltés ideje: 2015. augusztus 13.

UNU-INWEH [2015]: Water in the World We Want. URL: http://inweh.unu.edu/wpcontent/uploads/2015/02/Water-in-the-World-We-Want.pdf, letöltés ideje: 2015. május 20.

UN-Water [2008]: Transboundary Waters: Sharing Benefits, Sharing Responsibilities. URL: http://www.unwater.org/downloads/UNW_TRANSBOUNDARY.pdf, letöltés ideje: 2015. október 10.

UN-Water [2013a]: Facts and figures. URL: http://www.unwater.org/watercooperation-2013/water-cooperation/facts-and-figures/en/, letöltés ideje: 2015. május 20 .

UN-Water [2013b]: Water scarcity factsheet. URL: http://www.unwater.org/fileadmin/user_upload/watercooperation2013/doc/Facts heets/water_scarcity.pdf, letöltés ideje: 2015. május 20.

UN-Water [2013c]: Water quality factsheet. URL: http://www.unwater.org/fileadmin/user_upload/watercooperation2013/doc/Facts heets/water_quality.pdf, letöltés ideje: 2015. május 20.

UN-Water [2013d]: Climate Change Factsheet. URL: http://www.unwater.org/fileadmin/user_upload/watercooperation2013/doc/Facts heets/climate_change.pdf, letöltés ideje: 2015. május 20.

US Energy Information Administration (EIA) [2013]: Overview Data for Hungary. URL: http://www.eia.gov/countries/country-data.cfm?fips=hu\#elec, letöltés ideje: 2015. február 20.

Világbank [2010]: Uzbekistan: Climate Change and Agriculture Country Note. URL: http://siteresources.worldbank.org/ECAEXT/Resources/2585981277305872360/7190152-1303416376314/uzbekistancountrynote.pdf, letöltés ideje: 2014. december 10. 
Világbank [2012]: Tajikistan's Winter Energy Crisis: Electricity Supply and Demand Alternatives. URL:

http://siteresources.worldbank.org/ECAEXT/Resources/TAJ_winter_energy_27 112012_Eng.pdf, letöltés ideje: 2015. február 10.

Világbank [2013a]: Kyrgyz Republic: Overview of Climate Change Activities. URL: http://documents.worldbank.org/curated/en/2013/10/19185593/kyrgyz-republicoverview-climate-change-activities, letöltés ideje: 2015. október 10.

Világbank [2013b]: Tajikistan: Overview of Climate Change Activities. URL: http://documents.worldbank.org/curated/en/2013/10/19184409/tajikistanoverview-climate-change-activities, letöltés ideje: 2014. december 10.

Világbank [2013c]: Tajikistan. URL: http://data.worldbank.org/country/tajikistan, letöltés ideje: 2014. december 12.

Világbank [2014a]: Assessment Studies for Proposed Rogun Hydropower Project in Tajikistan. URL: http://www.worldbank.org/en/region/eca/brief/rogunassessment-studies, letöltés ideje 2015. február 17.

Világbank [2014b]: Key Issues for Consideration on the Proposed Rogun Hydropower Project. URL:

http://www.worldbank.org/content/dam/Worldbank/document/eca/centralasia/World\%20Bank\%20Note\%20-

\%20Key\%20Issues $\% 20$ for $\% 20$ Consideration $\% 20$ on $\% 20$ Proposed $\% 20$ Rogun $\% 2$ 0Hydropower\%20Project_eng.pdf, letöltve 2015. február 17.

Világbank [2014c]: Engineering and Dam Safety Panel of Experts for Rogun Hydropower Project. URL:

http://www.worldbank.org/content/dam/Worldbank/document/eca/centralasia/EDS\%20PoE\%20Report_FINAL_eng.pdf, letöltve: 2015. február 20.

Világbank [2015]: „World Bank Supports Energy Sector Development in the Kyrgyz Republic.” Press Release, 2015. január 29. URL:

http://www.worldbank.org/en/news/press-release/2015/01/29/world-banksupports-energy-sector-development-in-the-kyrgyz-republic, letöltés ideje: 2015. október 10.

WHO-UNICEF [2014]: Progress on sanitation and drinking water: 2014 update. http://apps.who.int/iris/bitstream/10665/112727/1/9789241507240_eng.pdf, letöltés ideje: 2015. május 20. 
World Commission on Dams (WCD) [2000]: „Dams and Development: A New Framework for Decision-Making.” 2000. november. URL: http://www.unep.org/dams/WCD/report/WCD_DAMS\%20report.pdf, letöltés ideje: 2016. január 21.

World Economic Forum [WEF] [2015]: The Global Risks Landscape 2015. URL: http://reports.weforum.org/global-risks-2015/\#frame/20ad6, letöltés ideje: 2015. május 20.

World Resources Institute [2015]: Water. URL: http://www.wri.org/ourwork/topics/water, 2015. május 20.

World Water Assessment Programme [WWAP] [2012]: World Water Development Report 4: Managing water under uncertainty and risk. UNESCO, Paris.

World Water Assessment Programme [WWAP] [2014]: The United Nations World Water Development Report 2014: Water and Energy. UNESCO, Paris.

Internetes források

A Tádzsik Köztársaság külügyminisztériumának hivatalos honlapja [2015]: The energy sector of the Republic of Tajikistan. URL: http://mfa.tj/en/energy-sector/theenergy-sector-of-rt.html, letöltés ideje: 2014. december 10.

al-Khalidi, Suleiman [2015]: „Jordan, Israel agree \$900 million Red Sea-Dead Sea project." Reuters, 2015. február 26. URL:

http://www.reuters.com/article/2015/02/26/us-mideast-economy-wateridUSKBNOLU23Z20150226, letöltés ideje: 2015. augusztus 18.

Aqueduct Country and River Basin Rankings. URL:

http://www.wri.org/applications/maps/aqueduct-country-river-basin-rankings, letöltés ideje: 2015. február 17.)

Az Országos Vízügyi Főigazgatóság hivatalos honlapja. URL:

http://www.ovf.hu/hu/hidrologia, letöltés ideje: 2015. október 2.

de la Vaissiére, Étienne [2005]: „,The Northern Side of the Zarafshan according to Ibn Hawqal. Central Asia from the Achaemenids to the Timurids: Archaeology, History, Ethnology, Culture.” Materials of an International Scientific Conference. St. Petersburg, November 2-5, 2004. 323-325. 
Demydenko, Andriy [2004]: „,The Evolution of Bilateral Agreements in the Face of Changing Geo-Politics in the Chu-Talas Basin." Summary of the keynote at International Conference "WATER: a Catalyst for Peace". Alternative approaches for the management of shared water resources, Zaragoza, Spain, 6-8 October 2004. URL:

http://webworld.unesco.org/water/wwap/pccp/zaragoza/basins/chu_talas/demyde nko.ppt, letöltés ideje: 2015. július 20.

Egyéb források

Eurasianet.org [2012]: „Uzbekistan-Tajikistan: When is a Blockade a Blockade?” URL: http://www.eurasianet.org/node/65230, letöltés ideje: 2015. október 10.

Gleick, Peter H. [2008]: Water Conflict Chronology. Database on Water and Conflict Water Brief. URL: http://worldwater.org/water-conflict/, letöltés ideje: 2015. október 10.

Hydroworld.com [2009]: Russia to Finance Kyrgyzstan's 1,900-MW Kambarata 1. URL: http://www.hydroworld.com/articles/2009/02/russia-to-financekyrgyzstans-1900-mw-kambarata-1.html, letöltés ideje: 2015. október 10.

Interfax [2012]: Kazakhstan has Own Terms for Building Kambarata HPP - Ministry. 2012. december 19. URL: http://www.interfax.com/newsinf.asp?id=383908, letöltés ideje: 2016. augusztus 22.

Ivanova, Anna [2011]: „Water Resources are the Basis for Sustainable Development and Future Progress.” Uzbekistan National News Agency, 2011. május 13. http://uza.uz/en/society/1929/, letöltés ideje: 2012. május 25.

Kabar [2011]: „Russia Will Supply Kyrgyzstan in 2012 with 1.1 Million Tons of Duty Free Fuel.” 2011. október 5. URL: http://kabar.kg/eng/economics/full/2310. Letöltés ideje: 2016. július 25.

Kabar [2012a]: „Kazakh Experts to Arrive in Kyrgyzstan to Consider the Possibility of Participation in Construction of Kambarata-1 HPS.” 2012. február 22. URL: http://kabar.kg/eng/politics/full/3533. Letöltés ideje: 2016. július 25.

Kabar [2012b]: „Central Asian Countries and Russia Discussed Participation in Construction of Kambarata-1." 2012. október 8. URL: http://kabar.kg/eng/economics/full/5246. Letöltés ideje: 2016. július 25. 
Kabar [2013a]: „Uzbekistan Through the UN Is Trying to Put Pressure on Kyrgyzstan and Russia on the Kambarata-1 HPP, Expert Says.” 2013. december 20. URL: http://kabar.kg/eng/politics/full/5886. Letöltés ideje: 2016. július 25.

Kabar [2013b]: „Expert: Hydroelectric Power Station Construction in Kyrgyzstan Must be Coordinated with Uzbekistan.” 2013. január 27. URL: http://kabar.kg/eng/economics/full/6175. Letöltés ideje: 2016. július 25.

Kabar [2013c]: „Almazbek Atambayev: "Toktogul HPP of Kyrgyzstan Is the Energy Object, but not a Vegetative".” 2013. március 18. URL http://kabar.kg/eng/society/full/6629. Letöltés ideje: 2016. július 25.

Kabar [2013d]: „Switzerland Allocates USD 950000 for the Promotion of KazakhKyrgyz Interstate Cooperation on Transboundary Chu and Talas Rivers.” 2013. április 25. URL: http://kabar.kg/eng/society/full/6969, letöltés ideje: 2016. augusztus 22 .

Kabar [2014a]: „Atambayev: "The construction of Kambarata-1 HPP is necessary not only for Kyrgyzstan, but also for Uzbekistan and Kazakhstan".” 2014. december 2. URL: http://kabar.kg/eng/economics/full/11600. Letöltés ideje: 2016. július 25.

Kabar [2014b]: „Джоомарт Оторбаев: Проблемы и потенциал развития электроэнергетики в Кыргызстане.” 2014. szeptember 14. URL: http://kabar.kg/rus/analytics/full/82578. Letöltés ideje: 2016. július 25.

Kabar [2015a]: „UNDP and UNECE Support Transboundary Water Cooperation in Chu and Talas Basins.” 2015. szeptember 30. URL:

http://kabar.kg/eng/society/full/14026, letöltés ideje: 2016. augusztus 22.

Kabar [2015b]: „Water Co-Operation between Kyrgyzstan and Kazakhstan Discussed at OSCE-Supported International Conference" 2015. szeptember 17. URL: http://kabar.kg/eng/society/full/13939, letöltés ideje: 2016. augusztus 22.

Kabar [2015c]: „Валентина Матвиенко: «Кыргызстан всегда был и остается надежным партнером России».” 2015. október 5. URL: http://kabar.kg/rus/politics/full/93182. Letöltés ideje: 2016. július 25.

Kabar [2015d]: „С.Нарышкин: «Мы постарается в ближайшее время рассмотреть ратификацию документов по присоединению КР к ЕАЭС».” 2015. május 26. URL: http://kabar.kg/rus/politics/full/93167. Letöltés ideje: 2016. július 25. 
Kabar [2016]: „Kyrgyz Parliament Denounces Agreement with Russia on Construction of Kambarata-1 HPP and Upper Naryn Cascade of HPPs.” 2016. január 20. URL: http://kabar.kg/eng/politics/full/14941. Letöltés ideje: 2016. július 25.

Kazinform [2009]: „Kazakh Ambassador meets Kyrgyz Minister of Agriculture and Chairman of People's Assembly of Kyrgyzstan.” 2009. október 14. URL: http://inform.kz/eng/article/2204785, letöltés ideje: 2016. augusztus 22.

Kazinform [2010]: „Kazakh, Uzbek Leaders Stand for International Expertise of Construction of New Hydroelectric Power Stations in Region.” 2010. március 27. URL: http://www.inform.kz/eng/article/2249123. Letöltés ideje: 2016. július 25.

Kazinform [2011]: „Massimov Congratulates Kyrgyz Acting PM on Successful Completion of Presidential Elections." 2011. október 31. URL: http://inform.kz/eng/article/2415744, letöltés ideje: 2016. augusztus 22.

Kazinform [2012]: „Kyrgyz-Kazakh Investment Fund Starts its Work.” 2012. május 10. URL: http://www.inform.kz/rus/article/2462594, letöltés ideje: 2016. augusztus 22.

Kazinform [2012a]: „Kyrgyzstan Proposes Kazakhstan to Participate in 'Kambarata-1' Hydro Power Plant Construction.” 2012. február 22. URL: http://www.inform.kz/eng/article/2443024. Letöltés ideje: 2016. július 25.

Kazinform [2012b]: „Кыргызстан предложил Казахстану участие в строительстве ГЭС «Камбарата-1».” 2012. február 22. URL: http://inform.kz/rus/article/2443012. Letöltés ideje: 2016. július 25.

Kazinform [2012c]: „Нужно провести международную экспертизу проектов строительства ГЭС в Кыргызстане и Таджикистане - И.Каримов.” 2012. szeptember 7. URL: http://inform.kz/rus/article/2492704. Letöltés ideje: 2016. július 25 .

Kazinform [2013]: „Kazakh PM Spoke to His Kyrgyz Counterpart over Bystrotok Water Channel." 2013. július 17. URL: http://www.inform.kz/eng/article/2575015, letöltés ideje: 2016. augusztus 22.

Keene, Eli [2013]: Solving Tajikistan's Energy Crisis. Carnegie Endowment for International Peace. URL: http://carnegieendowment.org/2013/03/25/solvingtajikistan-s-energy-crisis, letöltés ideje: 2015. február 10. 
Khovar [2012]: „Water Resources in Central Asia \& Afghanistan.” 2012. március 22.

URL: http://khovar.tj/eng/foreign-policy/2841-water-resources-in-central-asiaafghanistan.html, letöltés ideje: 2015. február 10.

Khovar [2015]: „President Emomali Rahmon Visited Rogun City on a Working Visit.” 2015. július 15. URL:

http://khovar.tj/eng/node?page=13\&option=com_content\&task=view\&id=5178

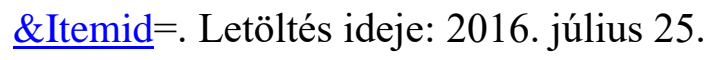

Khovar [2016a]: „Final Reports Related to the Proposed Rogun HPP.” 2016. július 22.

URL: http://khovar.tj/eng/final-reports-related-to-the-proposed-rogun-hpp/.

Letöltés ideje: 2016. július 25.

Khovar [2016b]: „The Results of the International Tender: Roghun HPP to be Built by Italian Company "Salini Impregilo".” 2016. július 1. URL:

http://khovar.tj/eng/2016/07/the-results-of-the-international-tender-roghun-hppto-be-built-by-italian-company-salini-impregilo/. Letöltés ideje: 2016. július 25.

Khovar [2016c]: „Leader of the Nation Received Chief Executive Officer of "Salini Impregilo” Dr. Pietro Salini.” 2016. július 1. URL:

http://khovar.tj/eng/2016/07/leader-of-the-nation-received-chief-executiveofficer-of-salini-impregilo-dr-pietro-salini/. Letöltés ideje: 2016. július 25.

Khovar [2016d]: „Дэвид Симпсон, американский эксперт в сфере сейсмологии : «Плотина Рогуна, так же как и Нурека, будет самой безопасной в мире»." 2016. június 2. URL: http://khovar.tj/rus/2016/06/devid-simpson-amerikanskijekspert-v-sfere-sejsmologii-plotina-roguna-tak-zhe-kak-i-nureka-budet-samojbezopasnoj-v-mire/. Letöltés ideje: 2016. július 25.

Khovar [2016е]: „Годовое собрание акционеров ОАО «Рогунская ГЭС».” 2016. május 27. URL: http://khovar.tj/rus/2016/05/godovoe-sobranie-aktsionerov-oaorogunskaya-ges/. Letöltés ideje: 2016. július 25.

Khovar [2016f]: „Встреча Д.Саида с предпринимателями Вахдата, Рогуна, Файзабадского и Варзобского районов.” 2016. március 3. URL: http://khovar.tj/rus/2016/03/vstrecha-d-saida-s-predprinimatelyami-vahdataroguna-fajzabadskogo-i-varzobskogo-rajonov/. Letöltés ideje: 2016. július 25.

Khovar [2016g]: „Оборудование для строительства Рогунской ГЭС беспрепятственно проходит через территорию Узбекистана.” 2016. január 28. URL: http://khovar.tj/rus/2016/01/oborudovanie-dlya-stroitelstva-rogunskoj- 
ges-besprepyatstvenno-prohodit-cherez-territoriyu-uzbekistana/. Letöltés ideje: 2016. július 25 .

Lillis, Joanna [2013]: „Kazakhstan and Kyrgyzstan in War of Words over Water.” Eurasianet.org, 2013. július 30. URL: http://www.eurasianet.org/node/67317, letöltés ideje: 2015. július 20.

Ministry of National Economy of The Republic of Kazakhstan [2015]: State Symbols of the Republic of Kazakhstan. URL: http://economy.gov.kz/en/symbols/, letöltés ideje: 2015. október 10.

Mirzorahmatov, Szalomiddin [2011]: Отахон жил, творил, боролся. Asia-Plus, 2011. március 17. URL:

https://web.archive.org/web/20110323015856/http://news.tj/ru/newspaper/article /otakhon-zhil-tvoril-borolsya, letöltés ideje: 2016. április 2.

Muzalevsky, Roman [2010]: „Shifting Regional Dynamics Force Russia to Suspend Promised Loan to Kyrgyzstan.” Eurasia Daily Monitor, Vol. 7. No. 50.

National Geographic [2015]: Freshwater crisis. URL:

http://environment.nationalgeographic.com/environment/freshwater/freshwatercrisis/, letöltés ideje: 2015. május 20.

Nurshayeva, Raushan [2012]: „Uzbek Leader Sounds Warning over Central Asia Water Disputes." Reuters, 2012. szeptember 7. URL:

http://www.reuters.com/article/2012/09/07/centralasia-wateridUSL6E8K793I20120907, letöltés ideje: 2015. február 10.

Panella, Thomas [2008]: „Transboundary Water Management in the Chu Talas Basins and Regional Cooperation for Water Resources in Central Asia." CAREC Senior Officials' Meeting, Baku, 25-26 September 2008. URL: http://carecprogram.org/uploads/events/2008/SOM-Sep/002_101_209_Session5Transboundary-Water-Management-Chu-Talas-Basins.pdf, letöltés ideje: 2016. augusztus 22 .

Parshin, Konstantin [2010]: „Uzbekistan vs. Tajikistan: Competition over Water Resources Intensifying." Eurasianet.org, 2010. december 8. URL: http://www.eurasianet.org/node/62528, letöltés ideje: 2012. december 5. 
Postel, Sandra L. - Wolf, Aaron T. [2009]: „Dehydrating Conflict.” Foreign Policy, 2009. november 18. URL: http://foreignpolicy.com/2009/11/18/dehydratingconflict/, letöltés ideje: 2015. augusztus 18 .

Rahmetov, Anvar [2009]: „Kyrgyzstan: Tracking Russia's Assistance Package to Bishkek.” Eurasianet.org, 2009. február 17. URL:

http://www.eurasianet.org/departments/insightb/articles/eav021809.shtml, letöltés ideje: 2015 . október 10.

Rushydro.ru [2012]: Камбаратинская ГЭС-1. Проект исключительной смелости. URL: http://blog.rushydro.ru/?p=7850, letöltés ideje: 2015. október 10.

Sadykov, Murat [2013]: „Uzbekistan: Tajik Language Under Pressure in Ancient Samarkand.” Eurasianet.org, 2013. november 5. URL: http://www.eurasianet.org/node/67724, letöltve: 2014. december 10.

Seventeen Moments of Soviet History: Great Ferghana Canal, URL: http://soviethistory.msu.edu/1939-2/great-fergana-canal/, letöltés ideje: 2016. április 2 .

Starr, Joyce R. [1991]: „Water Wars.” Foreign Policy, No. 82. (Spring) 17-36. URL: http://www.ciesin.org/docs/006-304/006-304.html, letöltés ideje: 2015. augusztus 13.

Stevenson, Struan [2011]: „Hydro-Power Stations Do Not Consume Water.” Khovar National Information Agency of Tajikistan, 2011. október 28. URL: http://khovar.tj/eng/energetics/2353-hydro-power-stations-do-not-consumewater.html, letöltés ideje: 2015. augusztus 13.

Szálkai Kinga [2012]: „Water Issues Are What States Make of Them: A Constructivist Approach to Conflict and Cooperation over Trans-Boundary Waters.” Chapter Two: The Relations of Uzbekistan and Tajikistan over the Amu Darya. Central European University, International Relations and European Studies MA. URL: www.etd.ceu.hu/2012/szalkai_kinga.pdf, letöltés ideje: 2016. augusztus 22.

Tarr, David - Trushin, Eskender [2004]: „Did the Desire for Cotton Self-Sufficiency Lead to the Aral Sea Environmental Disaster? A Case Study on Trade and the Environment." The World Bank. URL:

http://siteresources.worldbank.org/INTRANETTRADE/Resources/Topics/Acces sion/CaseStudyOnTrade\&Envir_Eng.doc, letöltés ideje: 2016. augusztus 22. 
The Council of Ministers of the Republic of Karakalpakstan [2015]: State Symbols of the Republic of Uzbekistan. URL: http://sovminrk.gov.uz/en/pages/show/6, letöltés ideje: 2015. október 10.

The Economist [2013]: „Hydropower in Tajikistan: Folie de Grandeur.” 2013. július 27. URL: http://www.economist.com/news/asia/21582325-president-edificecomplex-screwing-motherland-folie-de-grandeur, letöltés ideje: 2015. február 17.

The USGS Water Science School [2015]: How much water is there on, in, and above the Earth? URL: http://water.usgs.gov/edu/earthhowmuch.html, letöltés ideje: 2015. május 20.

Trilling, David [2016]: „Water Wars in Central Asia.” Foreign Affairs, 2016. augusztus 24. URL: https://www.foreignaffairs.com/gallerys/2016-08-24/water-warscentral-asia, letöltés ideje: 2016. augusztus 25.

Turton, Anthony R. [2001]: „Hydropolitics and Security Complex Theory: An African Perspective." Paper presented at the 4th Pan-European International Relations Conference, University of Kent, Canterbury (UK): 8-10 September 2001. URL: http://www.anthonyturton.com/admin/my_documents/my_files/52C_op38.pdf, letöltés ideje: 2015. október 10.

Turton, Anthony R. [2006]: „Hydro-Hegemony and Hydropolitical Complex Theory.” Second Hydro-Hegemony Workshop, 6-7 May 2006. London Water Research Group, Goodenough College. URL:

https://lwrg.files.wordpress.com/2014/12/turton-hh-and-hct-southern-africa.pdf, letöltés ideje: 2015 . október 10.

Umarova, Madina - Umarova, Iroda - Manzurova, Nodira [2011]: „Uzbekistan has Rich Experience in Rational and Efficient Use of Water Resources." Uzbekistan National News Agency, 2011. május 14. URL: http://uza.uz/en/politics/1932/, letöltés ideje: 2012. május 25.

University of Michigan [2015]: Water Scarcity: Tomorrow's Problem. URL: http://sitemaker.umich.edu/section9group6/data_and_figures, letöltés ideje: 2015. február 17.) 
UPI [2010]: Tajikistan Dam Project Hit by Controversy. Terra Daily, 2010. április 27. URL:

http://www.terradaily.com/reports/Tajikistan_dam_project_hit_by_controversy 999.html, letöltés ideje: 2016. április 2.

UzA [2010]: „Transboundary Environmental Problems Discussed.” 2011. május 14.

URL:

http://uza.uz/en/society/transboundaryenvironmentalproblemsdiscussed18.11.20 101655?sphrase_id=1471296. Letöltés ideje: 2016. július 25.

UzA [2011a]: „Water Resources are the Basis for Sustainable Development and Future Progress.” 2011. május 13. URL:

http://uza.uz/en/society/waterresourcesarethebasisforsustainabledevelopmentand futureprogress13.05.20111929?sphrase_id=1471296. Letöltés ideje: 2016. július 25 .

UzA [2011b]: „Uzbekistan has Rich Experience in Rational and Efficient Use of Water Resources." 2011. november 18. URL:

http://uza.uz/en/politics/uzbekistanhasrichexperienceinrationalandefficientuseof waterresources 14.05.20111932?sphrase id=1471296. Letöltés ideje: 2016. július 25 .

UzA [2012]: „Эксперты: от строительства Рогунской ГЭС придется отказаться.” 2012. március 16. URL: http://uza.uz/ru/society/eksperty-ot-stroitelstvarogunskoi-ges-pridetsya-otkazatsya-16.03.2012-18394? sphrase id=1137503. Letöltés ideje: 2016. július 25.

Wolf, Aaron T. (szerk.) [2013]: Transboundary Freshwater Dispute Database. Oregon State University. URL: http://www.transboundarywaters.orst.edu/, letöltés ideje: 2015. augusztus 18 .

Yildiz, Dursun [2014]:,,With Whom the Aral Sea was Crossed? Will it Return?” URL: http://www.hidropolitikakademi.org/en/with-whom-the-aral-sea-was-crossedwill-it-return.html, letöltés ideje: 2015. október 10.

Youtube [2010]: Afzalshoh Shodiev: Roghun. URL: https://youtu.be/MyAu9N1bxJw, letöltés ideje: 2016. április 2.

Zabarenko, Deborah [2009]: „As Climate changes, is Water the New Oil?” Reuters.com. URL: http://www.reuters.com/article/2009/03/22/us-climate-wateridUSTRE52L0TC20090322, letöltés ideje: 2015. augusztus 13. 


\section{A SZERZŐ PUBLIKÁCIÓI A DISSZERTÁCIÓ TÉMÁJÁVAL \\ KAPCSOLATOSAN ${ }^{24}$}

\section{Szerkesztett kötet}

Stepper Péter - Szálkai Kinga (szerk.) [2015]: A biztonság szektorális értelmezése. Új kihívások a kutatás napirendjén. Publikon, Pécs.

\section{Könyvfejezetek}

Szálkai Kinga [2015]: Szektorelmélet és biztonságiasítás. In: A biztonság szektorális értelmezése. Új kihívások a kutatás napirendjén. Szerk. Stepper Péter - Szálkai Kinga. Publikon, Pécs. 7-20.

Szálkai Kinga [2015]: A vízmegosztás biztonságiasításának változásai Közép-Ázsiában (1960-2010). In: A biztonság szektorális értelmezése. Új kihívások a kutatás napirendjén, szerk. Stepper Péter - Szálkai Kinga. Publikon, Pécs. 163-189.

\section{Folyóiratcikkek}

Szálkai Kinga [2014]: „Nonproliferáció garanciák nélkül? A közép-ázsiai atomfegyvermentes övezet kiegészítő jegyzőkönyvének kérdése.” In: Külügyi Szemle, 13. évf. 3. sz. (2014/3). 27-39.

Szálkai, Kinga [2013]: „Non-Proliferation without Assurances in Central Asia.” In: Asian Studies, Hungarian Institute of International Affairs. 186-194.

Szálkai Kinga [2013]: „A Sea or a Lake - What difference does it make? Questions of the delimitation of the Caspian Sea.” In: Biztonságpolitikai Szemle, 6. évf. 4. szám. 31-48.

\section{Konferenciakötetben megjelent tanulmányok}

Szálkai Kinga [nyomdában]: „Vízügyi feszültségek Közép-Ázsiában: A Rogun vízerőmü-rendszer kérdése.” In: Megcsalt reményünk. Szerk.: Keller László. XII. Nemzetközi Vámbéry Konferencia, Lilium Aurum. Dunaszerdahely.

\footnotetext{
${ }^{24}$ A felsorolt publikációk többsége a disszertációírás folyamata során íródott, annak szerves részeként, ezért részleteiben vagy átdolgozott változatában az értekezés részét képezi.
} 
Szálkai Kinga [2014]: „Törökország és Közép-Ázsia kapcsolatainak alakulása a Szovjetunió felbomlását követően.” In: Közel, s Távol III. Az Eötvös Collegium Orientalisztika Mühely éves konferenciájának előadásaiból. Szerk.: Takó Ferenc. Eötvös Collegium, Budapest. 189-202.

Szálkai Kinga [2013]: „Vas-út a hatalomba: Az orosz birodalmi vasúthálózat 19. század végi fejlesztésének hatásai Közép-Ázsiában.” In: Ábrándjaink kora. Szerk.:

Keller László. X. Nemzetközi Vámbéry Konferencia, Lilium Aurum, Dunaszerdahely. 269-295.

Szálkai Kinga [2012]: „Politikai iszlám: Alternatíva Közép-Ázsia számára?” In: Közel, s Távol II. Az Eötvös Collegium Orientalisztika Mühely éves konferenciájának előadásaiból. Szerk.: Takó Ferenc. Eötvös Collegium, Budapest. 79-88.

Szálkai Kinga [2012]: „A szovjet etnográfia szerepe a közép-ázsiai nemzeti identitások megteremtésében.” In: Az érett kor itélete. Szerk: Dobrovits Mihály. IX. Nemzetközi Vámbéry Konferencia, Lilium Aurum, Dunaszerdahely. 334-356.

\section{Recenzió}

Szálkai, Kinga [2015]: "Energy Challenges around the Caspian Sea.” (The Caspian Sea Chessboard: Geopolitical, geo-strategic and geo-economic analysis. Eds.: Carlo Frappi and Azad Garibov, Egea, 2014, 242 p.) In: BiztPol Affairs, Vol. 3. No. 1. 49-56.

\section{Online publikáció}

Szálkai Kinga [2014]: „Elméleti pluralitás a külpolitikai gyakorlatban. 2001. szeptember 11. realista, liberális és konstruktivista olvasata." In: Grotius, a Budapesti Corvinus Egyetem Nemzetközi Tanulmányok Intézetének tudományos folyóirata. URL: http://www.grotius.hu/publ/displ.asp?id=WHKQVM.

Az Antall József Tudásközpont AJRC-Elemzések sorozatában a témában megjelent gyorselemzések 2015 áprilisától a következő linken elérhetők: http://www.ajrcbudapest.org/\#!ajrc-elemzesek/ch01. 